UNIVERSIDADE DE SÃO PAULO

FACULDADE DE EDUCAÇÃO

ANA LUIZA JESUS DA COSTA

O educar-se das classes populares oitocentistas no Rio de Janeiro entre a escolarização e a experiência 
ANA LUIZA JESUS DA COSTA

\section{O educar-se das classes populares oitocentistas no Rio de Janeiro entre a escolarização e a experiência}

Tese apresentada à Faculdade de Educação da Universidade do Estado de São Paulo para a obtenção do título de Doutor em Educação

Área de Concentração: História da Educação e Historiografia Orientadora: Prof. Dr ${ }^{\mathrm{a}}$ Maurilane de Souza Biccas 
AUTORIZO A REPRODUÇÃO E DIVULGAÇÃO TOTAL OU PARCIAL DESTE TRABALHO, POR QUALQUER MEIO CONVENCIONAL OU ELETRÔNICO, PARA FINS DE ESTUDO E PESQUISA, DESDE QUE CITADA A FONTE.

Catalogação na Publicação

Serviço de Biblioteca e Documentação

Faculdade de Educação da Universidade de São Paulo

37.09 Costa, Ana Luiza Jesus da

B283s O educar-se das classes populares oitocentistas no Rio de Janeiro

entre a escolarização e a experiência / Ana Luiza Jesus da Costa;

orientação Maurilane de Souza Biccas. São Paulo: s.n., 2012.

274 p. ils.; tabs.

Tese (Doutorado - Programa de Pós-Graduação em Educação. Área de Concentração: História da Educação e Historiografia) - - Faculdade de Educação da Universidade de São Paulo.

1. Educação (Século XIX - Rio de Janeiro) 2. Escolarização 3. Classe baixa (Educação) 4. Trabalhadores 5. Operariado I. Biccas, Maurilane de Souza, orient. 
Nome: COSTA, Ana Luiza Jesus da

Título: O educar-se das classes populares oitocentistas no Rio de Janeiro entre a escolarização e a experiência

Tese apresentada à Faculdade de Educação da Universidade de São Paulo para obtenção de título de Doutora em Educação

Aprovado em:

\section{Banca Examinadora}

Prof. Dra . Maurilane de Souza Biccas. Universidade de São Paulo Julgamento: Assinatura:

Prof. Dr ${ }^{\mathrm{a}}$ Alessandra Frota Martinez de Schueler. Universidade Federal Fluminense Julgamento: Assinatura:

Prof. Dr ${ }^{\mathrm{a}}$ Laura Antunes Maciel. Universidade Federal Fluminense Julgamento: Assinatura:

Prof. Dr. Luciano Mendes de Faria Filho. Universidade Federal de Minas Gerais Julgamento: Assinatura:

Prof. Dr ${ }^{\mathrm{a}}$ Maria Angela Borges Salvadori. Universidade de São Paulo Julgamento: Assinatura: 
Dedico o fruto dos quatro anos de trabalho aos meus queridos Luzia (mamãe), Junior, Luciana e o pequeno Pedro a quem entrelaço minha vida e assim já não sei onde terminam eles e começo eu. 


\section{Agradecimentos}

Não é fácil encontrar as palavras para redigir os agradecimentos. O que me vem em mente nesse exato momento para expressar a importância dessa seção é uma pergunta: como seria um campo acadêmico que levasse em conta as vezes que uma pessoa aparece mencionada nos agradecimentos tanto quanto considera as que ela foi citada na bibliografia?

“Como se faz com todo cuidado a pipa que precisa voar", aqui vou eu, já recordando, enquanto vivo, o valor das trocas, aprendizados e acolhimento que tive numa cidade tão gigantesca, junto a um grupo tão aconchegante. Assim agradeço a competência e sensibilidade das professoras Diana Vidal, Maurilane Biccas e Maria Angela Salvadori e ao Grupo Interdisciplinar de Ensino e Pesquisa em História da Educação (NIEPHE) pela qualidade do debate acadêmico alegrado pelos tradicionais cafés da manhã a cada início de semestre. Cabe registrar que o texto de qualificação que deu base à tese e o capítulo referente à imprensa foram cuidadosamente lidos e debatidos pelo grupo.

Agora que minhas idas e vindas entre Rio e São Paulo vão chegando ao fim, vou contar que, muitas vezes, ao entrar no metrô lotado, na estação Tietê, após sete horas de estrada, pensei: "o que estou fazendo aqui?!”. Mas, quando encontrava o grupo, iniciavam-se as aulas e reuniões, davam-se os debates que se estendiam pelas conversas amigas na hora do café, entendia perfeitamente a razão do esforço e retornava à casa satisfeita por ter valido a pena. Sentirei saudades dessas travessias.

No primeiro ano de doutorado, lembro que compartilhei parte das viagens com Inára Garcia e Ana Luiza Grillo.

À Fabiana Munhoz agradeço, com carinho, as parcerias nos trabalhos de disciplinas e a companhia nos congressos.

À Patrícia Coelho agradeço as boas conversas, numa trajetória que vem, curiosamente, se encontrando desde o ingresso no mestrado, na turma de 2005 do Proped/UERJ e, agora, novamente, no doutorado.

Lembro os felizes encontros com Renata Simões durante as pesquisas na Biblioteca Nacional e no Arquivo Público do Estado do Rio de Janeiro.

Lembro, ainda, da presença constante e sorridente de Marlene Borges.

Nos últimos anos tive o prazer de reencontrar Angélica Borges, contemporânea também no NEPHE/UERJ e Rachel Duarte, que conheci no primeiro Intergrupos de História da Educação, em Araraquara, momento em que eu acabava de entrar para o campo. E o prazer de conhecer Rosângela Ferreira, Daniela Abreu, Fernanda Resende, Sandra Caldeira.

Registro ainda o agradecimento aos colegas com quem cursei disciplinas na FEUSP, lembro 
agora de Ana Paula Martins e Débora Querido.

Em terras fluminenses tive o privilégio de discutir o segundo capítulo da tese com o grupo de estudos em história social da educação, orientado pela professora Alessandra Schueler, da Universidade Federal Fluminense, em reunião que contou com a presença do grupo da professora Irma Rizzini da Universidade Federal do Rio de Janeiro.

À Alessandra, agradeço a generosidade do convite, antes dele, à leitura atenciosa do projeto de ingresso ao doutorado, a oportunidade de ler, discutir e assim aprender sobre a obra de E. P. Thompson, e um sem número de referências bibliográficas da historiografia dos oitocentos. Agradeço, ainda, o debate enriquecedor e fraterno, junto com a professora Maria Angela Salvadori, durante a banca de qualificação desse trabalho. Ambas contribuíram muito para seu adensamento teórico e para a segurança da pesquisadora no caminho traçado.

À professora Maurilane Biccas, a quem o termo "orientadora" não caracteriza totalmente, agradeço, além da orientação competente, a confiança e as oportunidades de crescimento acadêmico e pessoal por ela proporcionadas. As missões em São Tomé e Príncipe expandiram minha visão de mundo e já se tornaram uma marca profunda em minha formação. Mas, para, além disso, agradeço por ter ganhado uma amiga, especial figura humana em seu despojamento e solidariedade.

Não seria possível deixar de fora outra dimensão extremamente importante de minha formação profissional e humana. Aquela que vem se processando junto aos colegas da Escola Municipal Maestro Heitor Villa Lobos, na Ilha da Conceição, em Niterói. Neles, procuro lembrar outros professores e funcionários das escolas por que passei nos últimos cinco anos. Agradeço o aprendizado das nuances do ofício de professor, que não nos são ensinadas na licenciatura. Agradeço pela partilha de momentos difíceis na unidade escolar e nas lutas políticas da categoria, porém, também as alegrias das confraternizações e conquistas. A cada momento que observo a seriedade e competência do trabalho de Elisa, Silvério, Gisele, Eni, Ana Lúcia, Lilian, Eires, Renato, Jorge, Cida, Fátima, Arminda e tantos outros que peço desculpas por não citar os nomes, fico a me perguntar: quem disse que o professor de educação básica das escolas públicas não constrói conhecimento?!

A última greve dos profissionais de educação do Município de Niterói, acontecida entre agosto e setembro de 2011, foi marcada por um debate político qualificado e por participações íntegras. Registro o agradecimento aos colegas da rede municipal por esses momentos ímpares em que "educamo-nos" um pouco mais politicamente.

Durante quatro anos, muitas pessoas passam por nossas vidas e, em alguns casos, influenciam de forma marcante o próprio trabalho. Entre elas, gostaria de agradecer a Itacir Luz que, mais de uma vez, insistiu para que eu visse "os rostos" dos obreiros do passado em todo o seu colorido. 
Participaram da viabilização da tese e de minha vida estudantil, portanto agradeço, aos funcionários das instituições onde realizei pesquisas e aos funcionários da FEUSP.

À Capes por tornar mais fácil os deslocamentos, obtenção de material, idas a congressos e a própria sobrevivência no tempo dispensado a pesquisa e escrita.

Novamente, àquelas pessoas que são o motivo de minha trajetória de investigação e docência - aos estudantes de classes trabalhadoras que me despertaram desde quando, ainda na graduação, fiz parte do projeto de educação popular/alfabetização de adultos desenvolvido pela Oficina de Ciências Sociais em comunidades pobres de Niterói e do Rio. Aos estudantes "mais pequenos" com quem trabalho hoje, filhos das classes trabalhadoras, pois mesmo "ralhando" as vezes, o faço por querê-los bem.

E, por fim, pois que se não, não acabam nunca, os agradecimentos à minha família por ser sustentáculo e exemplo em mais uma etapa de minha carreira e de tudo o que vivo. 
É isso a utopia - a regeneração de todas as coisas mediante um intenso trabalho mental. Trabalho este que já não tem a ver com o que [chamamos] de intelectual; porque não é a rotina profissional de um funcionário do saber, é esforço quase maldito de mudar, de vencer os limites do pensamento, da imaginação, da sensibilidade (C. Hill, O Mundo de Ponta Cabeça). 


\section{Resumo}

Tendo como pressuposto o papel ativo das classes populares em sua própria educação, a presente tese procurou compreender e explicitar as experiências educacionais destes sujeitos na corte/capital federal e província/estado do Rio de Janeiro na segunda metade do século XIX e primeiros anos do século XX. Tais experiências foram apreendidas em três acontecimentos históricos: nas associações de trabalhadores, na imprensa operária e nas lutas por escolarização levadas a cabo por "chefes de família" e "pais de família" nas freguesias suburbanas e rurais da corte e da província do Rio de Janeiro. Nesses espaços pudemos identificar o que chamamos do "educar-se" das classes populares oitocentistas e suas representações de educação. A análise de estatutos e relatórios das associações de trabalhadores, pareceres do Conselho de Estado do Império recomendando a aprovação ou recusa desses estatutos, dos jornais produzidos por trabalhadores e dos abaixo-assinados pedindo ao Estado Imperial a abertura ou reabertura de escolas, permitiu-nos afirmar a importância das lutas das classes populares, desde pelo menos a segunda metade do século XIX na transformação do status da educação oferecida ao povo de dádiva a direito.

Associações de trabalhadores; imprensa operária; educar-se; classes populares; experiência; luta por escolarização. 


\begin{abstract}
The main objective of this thesis was to enumerate and make a comprehensive analyzes of the educational experiences of the popular classes in the court/federal capital and province/state of Rio de Janeiro during the second half of the nineteenth-century and the first years of the twentieth-century assuming the active role of the popular classes in their own education. Such experiences were learned from three historical events: the worker's associations; the worker's press; and the movements for education leaded by householders in the suburban and rural parish of the court and the province of Rio de Janeiro. In these groups we were able to identify what we have called "autoeducation" of the popular classes of the nineteenth-century and its educational representations. Analyzes of the statutes and reports from the worker's associations and the resolutions from the imperial Council recommending or not its approval, the newspapers produced by workers and the petitions demanding from the imperial state the opening and reopening of schools allowed us to reaffirm the importance of the struggles of the popular classes, since at least the second half of the nineteenthcentury, to transform the status of the education offered to the popular classes from "a gift" to a right.
\end{abstract}

Worker's association; worker's press; auto-education; popular classes; experiences; struggles for education 


\section{Lista de Ilustrações}

Figura 1: No cabeçalho de O Panificador, de 1 de janeiro de 1900, uma referência bem humorada à irregularidade de publicação: Aparece quando pode" 158

Figura 2: Ilustrações do artigo "Catechismo de máquinas a vapor" por C. H. Bellanger, em O Artista, de 29 de janeiro de 1871

Figura 3: A irônica seção “Telephonia Padeiral”, em O Panificador, de 1 de janeiro de 1900 .... 184

Figura 4: Imagem de exemplar mutilado da Gazeta dos Operários. É relativamente comum encontrar jornais operários do século XIX em condições como esta

Figura 5: Relação das Freguesias do Rio de Janeiro onde não há escolas públicas. Imagem retirada do Relatório do Presidente de Província do Rio de Janeiro para o ano de 1885. 


\section{Lista de Tabelas}

Tabela 1: Nomes das associações e respectiva documentação consultada 78

Tabela 2: Práticas educacionais das associações atuantes de 1870 até 1889

Tabela 3: Práticas educacionais das associações fundadas a partir de 1890 até 1917 134

Tabela 4: Jornais operários editados em português entre a segunda metade do século XIX e início do século XX no Rio de Janeiro 144

Tabela 5: Periódicos da imprensa operária 156 


\section{Sumário}

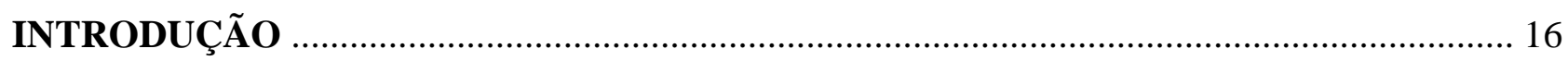

CAPÍTULO 1: Povo, Política e Educação no Século XIX ........................................................ 26

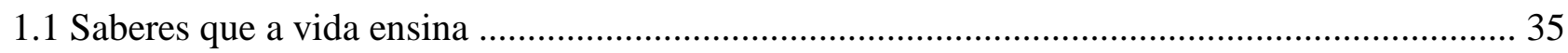

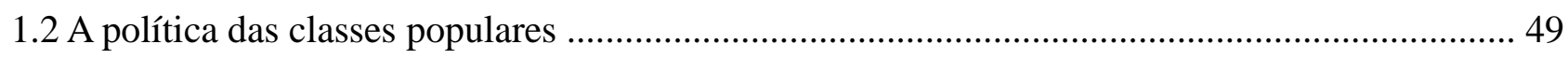

CAPÍTULO 2: Formas do educar-se nas organizações das classes trabalhadoras ....................... 73

2.1 Caracterização das organizações quanto as fontes............................................................ 78

2.2 Quem é a classe: paternalismo e conflito no universo das organizações de trabalhadores ........ 92

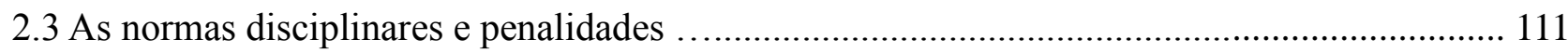

2.4 Indícios de práticas democráticas .............................................................................. 114

2.5 Diversidade e estratificação das organizações de trabalhadores e nas organizações de

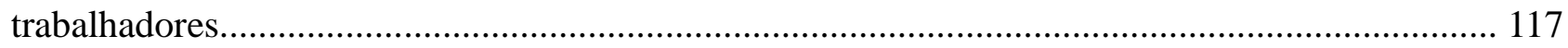

2.6 Relações entre sociedades e cultura mutualista ............................................................. 124

2.7 Práticas educacionais formativas entre a experiência e a escolarização ............................... 127

CAPÍTULO 3: A educação das classes trabalhadoras na imprensa e pela imprensa 144

3.1 Caracterização da imprensa dos trabalhadores 144

3.2 Caracterização dos impressos analisados 
3.4 Representações de educação 200

CAPÍTULO 4: Luta por escolarização: as classes populares reconhecem o papel da escola ... 217

4.1 A demanda popular por escolarização e as escolas subvencionadas 219

4.2 A reivindicação popular: abaixo-assinados solicitando escolas 245

CONSIDERAÇÕES FINAIS 257

BIBLIOGRAFIA 261

FONTES 269 


\section{Introdução}

Um trabalho acadêmico tem sua própria história - momento no tempo e no espaço - fazer uma tese também é a experiência de elaborar uma tese. A escrita subverte a ordem da pesquisa (CERTEAU, 1982) e a escrita da Introdução é a subversão na subversão, a parte inicial que escrevemos no final. Além de que, existem muito mais elementos envolvidos na vivência de um pesquisador do que a própria pesquisa e a escrita. No cotidiano do qual não podemos nos desvencilhar, estiveram presentes nos últimos meses, risos e choros de criança, falatório de adolescentes em salas de aula, uma greve de professores ${ }^{1}$ cobrando posicionamento, seus sons nas ruas e assembleias. Ação e reflexão no movimento de minha própria categoria profissional que me deram outra dimensão de categorias como "cultura de classes", e do caráter educativo/formativo das associações de trabalhadores, agora que estou atenta a elas, concepções tão caras à presente tese.

Não é possível desconsiderar, porém, o esforço mais ou menos solitário de burilar ideias em forma de palavras. Penso nisso cada vez que retorno a primeira, segunda ou terceira versão desse texto. Quando faço e refaço construções de frases, mudo parágrafos de posição, leio e releio anotações e após ler e reler, reescrevo, buscando em um e outro "fichamento" matéria-prima para meu próprio texto. Os autores tomados como referência nos oferecem ferramentas teóricas. Sintome, então, cada vez mais próxima daqueles artesãos oitocentistas com quem procuro, junto à outros sujeitos populares, dar vida e cor à inerte e branca folha de papel em minha frente.

March Bloch em sua Apologia da História sugere que o historiador deixe transparecer em seu produto final, os caminhos de sua constituição. "Todo livro de história deveria comportar um capítulo ou uma série de parágrafos que se intitulariam algo como 'Como posso saber o que vou lhes dizer"' (BLOCH, 2001, p. 83). O olhar retrospectivo, ou uma mirada "de longe" para a trajetória do conhecimento aqui materializado, demarca como seu ponto de partida as lacunas abertas pela dissertação de mestrado desenvolvida sobre as escolas noturnas de instrução primária para trabalhadores na corte entre 1860 e 1889.

Mantida, desde o início, a preocupação com a educação popular que deriva antes do interesse por esses sujeitos - as classes populares - heterogêneos, sem dúvida, mas que podem ser identificados ao menos quando entramos nas escolas públicas do Rio de Janeiro e olhamos um pouco para as histórias dos alunos: de onde vêm, onde moram, seu dia a dia, suas preferências musicais, religiosas, suas formas de lazer, o que esperam da escola, quem são e o que fazem seus familiares e amigos, seu modo de se expressar oralmente e por escrito, são alguns traços que os individualizam, mas também os identificam como sujeitos marcados pela necessidade incondicional

1 Trata-se da greve de profissionais de educação do Município de Niterói/RJ, realizada entre agosto e setembro de 2011 reivindicando ajustes no plano de carreira de funcionários e professores, entre outros pontos de pauta. 
do trabalho, por necessidades materiais muitas vezes não supridas, portadores de muitos estigmas como cor, gênero, local de moradia, grau de instrução, submetidos a arbitrariedades de poderes públicos e privados (polícia, em alguns casos a própria escola, patrões e empresas, entre elas o próprio tráfico de drogas).

São esses mesmos sujeitos que a partir de 2009 passaram a financiar meu estudo via agência de fomento governamental ${ }^{2}$. Tomando o investimento público sob a forma de bolsa de estudos como um condicionante desta atividade, remeto aos sujeitos citados um segundo condicionante - o posicionamento político do pesquisador. Ao mesmo tempo deixo explícito meu compromisso não apenas com o rigor científico e as normas acadêmicas, mas com a busca da relevância da pesquisa para além do espaço universitário, para a construção de uma história em respeito à memória e à experiência dos homens e mulheres que mais têm sofrido com a estratificação da e pela educação, mas que em muitos casos têm encontrado nela satisfação de alguns anseios, ferramenta para integração e ascensão possíveis, mas também subversão ou sonhos imagináveis.

Desde então, a busca aqui empreendida encontra outro condicionante - o acesso às fontes de informação. Falar de povo no século XIX é deparar-se com ausências de discursos diretos, por um conjunto de pessoas majoritariamente não alfabetizadas, nem habituadas a registrar seus pensamentos ou atos. E quando produzidos, havia pouca probabilidade de terem seus registros preservados e disponibilizados à consulta pública. Trabalhando com escritos anexados à processos judiciais de escravos, por exemplo, cartas escritas pelo pedreiro Claro Antonio dos Santos, escravo de ganho, Maria Cristina Wissenbach aborda o tema da escrita entre os cativos tendo como pressuposto uma animadora sentença de Armando Momigliano - "As fontes podem ser encontradas se temos a tenacidade de ir procurá-las" (WISSENBACH, 2002, p. 106).

Mas uma fonte histórica não existe autonomamente, numa prateleira, esperando ser "descoberta" para compor a narrativa histórica, por isso gostaria de discutir um último condicionamento: a opção teórico-metodológica. Segundo Meneses (2005, p. 28) “o documento é um suporte de informação. (...) É, pois, a questão de conhecimento que cria o sistema documental. O historiador não faz o documento falar: é o historiador quem fala e a explicitação de seus critérios e procedimentos é fundamental para definir o alcance de sua fala".

Os questionamentos e a visão de mundo contidos neste trabalho encontram coerência em determinado posicionamento teórico no qual é possível conduzir a abordagem de fontes oficiais, como a legislação e a documentação administrativa do Estado ou de entidades privadas, procurando nelas os indícios da história contada pelos sujeitos que estes mesmos documentos visam conter. Em outras palavras, para a educação do povo no século XIX, trata-se de ver este material "a partir de

2 Afirmativa que considera o conjunto dos trabalhadores de uma sociedade como produtores da riqueza nacional alocada em diferentes áreas de desenvolvimento, inclusive a pesquisa acadêmica. 
baixo" (THOMPSON, 2001). Dessa forma procuro perceber o conflito naquilo que tais fontes oficiais apresentam como hegemonia: a necessidade de se educar o "povo ignorante". Daí que se pode sustentar uma interpretação dos usos político-sociais da educação: o descrédito dos saberes dessa população a quem fora vedado o direito do voto, impondo como condição o alfabetismo, estava profundamente relacionado à intenção de seu alijamento do processo decisório. Mas, esse era o desejo de legisladores, bacharéis, ou mesmo de classes médias urbanas de que o povo não pensasse e não agisse por si mesmo. Desejo contrariado pela constante luta popular, no campo das possibilidades, entre outros fins, também por educação. Os rumos que assumiram as perguntas desta investigação direcionaram a busca para além de fontes oficiais, porém em nenhum momento o discurso da documentação não oficial foi assumido como "a verdade" em si mesma.

$\mathrm{Na}$ elaboração do projeto de doutorado, percebia duas grandes lacunas. Primeiro, a necessidade de aprofundamento sobre as iniciativas particulares em educação para as classes populares, prioritariamente aquelas organizadas por associações filantrópicas, tais como: Associação Promotora das Belas Artes (promotora do Liceu de Artes e Ofícios); Sociedade Auxiliadora da Indústria Nacional; Sociedade Promotora da Instrução às Classes Populares da Lagoa; Sociedade Amante da Instrução; etc. Segundo, o papel ativo das classes populares em sua própria educação. A primeira lacuna pareceu-me, a princípio, seguramente tratável, pois já havia travado contato com fontes a respeito daquelas sociedades. A segunda lacuna pareceu-me uma aspiração mais ou menos inacessível.

Decidida a enfrentar, prioritariamente, a primeira lacuna, interroguei "a forma pela qual a sociedade civil participou da implantação do chamado projeto político pedagógico elitista ${ }^{3}$, ou se em algum momento possibilitou formas de resistência ao projeto político e social de implantação da modernidade capitalista na segunda metade do século XIX, na corte e província do Rio de Janeiro"4. O desenvolvimento da pesquisa em fontes primárias e das leituras teóricas e historiográficas permitiram não só realizar acréscimos às contribuições da dissertação, mas, ainda, fazer uma investida crítica sobre suas proposições. A primeira proposição abordada de forma crítica diz respeito à existência de um projeto político pedagógico elitista identificado nas iniciativas de educação para o povo, desenvolvidas tanto pelo Estado Imperial, quanto por particulares, ou como passei a chamar - pela sociedade civil oitocentista. Com esse termo procurava caracterizar a postura de legisladores, gestores públicos, intelectuais e mesmo lideranças dos trabalhadores para quem as classes populares eram "objeto a ser moldado" e não sujeitos ativos.

Num cenário de transformações sociais e políticas que ecoavam mais fortes no meio urbano,

3 Termo utilizado em minha dissertação de mestrado A Luz das Lamparinas. As escolas noturnas para trabalhadores no Município da corte para caracterizar o projeto que embasava as escolas noturnas.

4 Trata-se de trecho do projeto inicial tal como lá aparece para melhor marcar as mudanças ocorridas. 
com o crescimento populacional, as reformas em busca dos ideais civilizatórios importados da Europa e Estados Unidos, crescimento da imprensa e formação de uma “opinião pública”, a própria reforma eleitoral que instituía a necessidade da alfabetização para os votantes, e, fator fundamental para entendermos as últimas décadas do XIX no Brasil, a crise do sistema escravista, a educação de ex-escravos e gerações que os sucederiam e da população de trabalhadores livres pobres em geral, entra definitivamente na pauta do Estado Imperial e de sujeitos que buscavam influência política e social. Medidas como, escolas noturnas para trabalhadores, instituições para ensino de ofícios, asilos para infância desvalida, etc. foram implementadas, não sem conflitos e dificuldades, como estratégias de "salvação" e "regeneração" da massa de "ignorantes" que compunha a população da corte e da província, além de seu controle para proteção da "boa sociedade".

Longe de ser medida humanitária, a educação para o "povo miúdo" (MATTOS, 1994), entendam-se, as primeiras letras, moral religiosa e ensino de ofícios, tinha por objetivo hierarquizar saberes e posições sociais, na tentativa de controlar sua circulação e seus usos. É nesse movimento que podemos observar, desde cedo, a construção de um mito social e político que vigora até hoje e que chamei de "invenção do analfabeto". A associação de características como analfabetismo, pobreza, vício, propensão ao crime, falta de higiene, ingenuidade, ignorância, incapacidade política, além de determinado fenótipo (associado à raça) num mesmo sujeito, deduzindo de uma todas as outras, forneceu a imagem de quem deveria ser controlado e quando necessário punido, alvo por vezes do medo, por vezes da piedade, regenerado poderia ser útil "a si e à nação", renitente fornecia a justificativa para as condições de desigualdade e exploração, tidas como "fracasso" ou "destino" de toda uma classe.

Repensando a solidez dessa hegemonia que impregna o discurso das fontes governamentais e civis, podemos perceber que esse "invento" não se fez tão passivo como seus criadores o queriam. Ao abandonar o desejo de ver, no contexto estudado, a formulação de um contra projeto popular, mergulhei naquilo que havia pincelado no projeto de doutorado como "indícios de resistência aos valores constituintes do projeto elitista", talvez os levando "mais a sério", com menos medo de encarar as ausências de documentação massiva. Um corte importante se processou desde então, uma percepção vaga, uma "intuição" surgida na pesquisa sobre as escolas noturnas: o papel ativo dos sujeitos na construção de suas próprias experiências, que não tive a oportunidade de localizar nos documentos $^{5}$ consultados no mestrado, ganhou robustez e se tornou centro da pesquisa do

5 Interessante observar a brecha pela qual se desenvolveram as concepções da tese de doutorado, presentes já na introdução da dissertação de mestrado, mas percebidas apenas a posteriori pela pesquisadora. "Deparei-me há dois anos, com as escolas noturnas de educação para o povo no século XIX, experiência que desconhecia até então, e não me passava pela cabeça estudá-la. Ao me aproximar desse objeto tive muita vontade de encontrar indícios que mostrassem sua participação em algum movimento de contestação ou projeto de mudança da sociedade vigente. A pesquisa, no entanto, mostrou um quadro bem diferente, onde vemos desenhar-se desde cedo o caráter subalterno da 
doutorado. Foi necessária uma decisão teórico-metodológica e política de procurar por essas experiências. Isso envolveu um mergulho mais profundo nos referenciais da história social e cultural, notadamente E. P. Thompson, mas também M. De Certeau, C. Hill, N. Z. Davis, R. Chartier, R. Darton, C.Ginzburg. E o enfrentamento do medo das lacunas que encontraria na documentação.

As primeiras buscas de informação sobre as sociedades voltadas para instrução das classes populares já revelara uma expansão do fenômeno associativo de forma ampla. Neles apareceram, frequentemente, inclusive, associações promovidas pelos próprios trabalhadores para as práticas de auxílio mútuo e beneficência. Diante da amplitude desse fenômeno e das já citadas escolhas teóricometodológicas e políticas, fiz um recorte no universo da sociedade civil que delimitou as associações de trabalhadores como foco. Do diálogo entre a teoria e a empiria, derivaram duas ideias força que passaram a orientar o desenvolvimento da tese: a busca pelas representações de educação e a busca pelo educar-se $e^{6}$ das classes populares oitocentistas.

Cosiderando a importância da relação de classes com o processo de implantação da educação escolar, tivemos em mente uma concepção mais ampla de educação - o educar-se como a experiência vivida, o ensinar e aprender entre os próprios sujeitos populares, mesmo fora da escola, fosse em associações de trabalhadores, ou de forma mais difusa em seu cotidiano. Não se tratou, em nenhum momento, de negar a dominação cultural das elites imperiais, mas pensar de que forma a educação pode ser apropriada pelas classes populares.

A análise de experiências de associações de trabalhadores tanto de auxílio mútuo e

educação destinada ao povo trabalhador. Os mais preocupados, nesse momento, com a sua escolarização eram exatamente o Estado e as elites econômicas e intelectuais, frente à necessidade de controle social e da prevenção contra a "desordem" pelo medo de revoltas de escravos ou homens livres pobres, pois exemplos não faltaram durante o século XIX, seja na Europa ou na própria América. A título de ilustração, podemos lembrar que o ano em que é assinada, no Brasil, a Lei do Ventre Livre, é também o ano em que o povo parisiense toma o poder e estabelece a Comuna de Paris. Mas, outras preocupações como a constituição de um trabalhador disciplinado para a dinâmica de um mercado de trabalho assalariado a partir da crise do escravismo, a própria equiparação dos indicadores sociais do Brasil frente às nações modernas, a formação de uma "clientela" de votantes a partir do estabelecimento do censo literário também se constituíram em motivações para a intervenção do Estado e dos "beneméritos" na escolarização das classes populares. A partir das contribuições do campo da história social e da nova história cultural que ressaltam o papel ativo dos sujeitos na construção de suas experiências, não simplesmente aceitando o que lhes é imposto, mas se apropriando e ressignificando a ordem que provém das posições de "mais poder", têm se desenvolvido pesquisas que tomam como foco as ações destes sujeitos e coletividades antes desconsiderados nas páginas da história política tradicional. É o caso daquelas que mostram os diferentes usos dados aos saberes difundidos pela escola. Apesar de não ter tido a oportunidade de localizar documentos que explicitassem essas apropriações, concordo com a tese da potencialidade da instrução para os usos próprios das classes populares, entretanto ressalto que a positividade de realizações como as escolas noturnas encontram-se principalmente nas subversões de seu projeto político pedagógico originalmente voltado para o controle e formatação do trabalhador aos interesses das elites que as promoviam" (COSTA, 2007, p. 12).

6 Termo adaptado pela reflexão educacional a partir da obra de Thompson (2004), referencial desta tese. Educar-se encontrou inspiração na concepção processual do historiador inglês em seu "making of the english working class", que traduzido em português por "formação da classe operária inglesa", procura ressaltar o movimento histórico perpetrado pelos próprios trabalhadores de se "autofazerem" como classe. Constatamos aqui que a educação participa da formação da classe e se forma ao mesmo tempo, pela ação dos trabalhadores. 
beneficência, com ou sem caráter profissional e, mais tarde, associações de resistência acabou por tomar um terreno mais amplo nas lutas por educação no período. Foi estendida para a investigação das reivindicações por escola levadas a frente por moradores de freguesias suburbanas do município da corte e de freguesias rurais da província do Rio de Janeiro por meio de abaixo-assinados. Tal demanda popular foi, na maior parte das vezes atendida sob a forma, não exatamente de escolas públicas, mas de escolas subvencionadas para os alunos pobres. Por fim, compõe as experiências educacionais das classes populares oitocentistas aqui abordadas, suas manifestações na imprensa e os usos feitos dos periódicos. A leitura desses fazeres entretecidos nos permitiu afirmar que a luta por educação levada a cabo pelas classes populares no Rio de Janeiro oitocentista ajudou a definir os rumos das políticas educacionais.

Diante da reconfiguração do objeto de estudo e das novas perspectivas adotadas foi desenhada uma nova hipótese central que pode ser verificada no conjunto de fontes utilizadas, qual seja: a importância do papel das lutas das classes populares, desde pelo menos a segunda metade do século XIX, na transformação do status da educação oferecida ao povo de dádiva a direito social.

A educação não era um direito social no período estudado. Mesmo estando presente na constituição imperial de 1824, quando afirma que a instrução seria gratuita a todos os cidadãos categoria restritiva naquele momento - não prescrevia de quem seria o dever de provê-la. A instrução era considerada no documento como meio de garantia dos direitos civis e políticos dos cidadãos do império e não um direito social em si mesma.

As relações de dádiva que já vinham sendo observadas desde os estudos sobre as escolas noturnas promovidas por "beneméritos" - membros de elites imperiais, representantes do poder privado, que adotaram a "missão" de "derramar a instrução pelo povo" - puderam ser compreendidas "a partir de baixo". Elas foram matizadas em cenas de luta por educação, mais ou menos aberta, mais ou menos negociada, ou do uso da educação como ferramenta de luta por outras necessidades materiais ou imateriais das classes populares encontradas em uma rica documentação.

Alguns achados nos acervos da Biblioteca Nacional, do Arquivo Nacional, do Arquivo Público do Estado do Rio de Janeiro e do Arquivo Geral da Cidade do Rio de Janeiro pareceram, as vezes, presentes do acaso, sem menosprezar a já citada disposição em buscar por eles. Foi emblemático dessa "dádiva casual" o último rolo de microfilme consultado, já no fim da pesquisa, encontrado no setor de obras raras da Biblioteca Nacional contendo diversos jornais operários das últimas décadas do século XIX e início do XX.

A documentação foi organizada em quatro grandes conjuntos que deram origem aos quatro capítulos da tese. $\mathrm{O}$ primeiro a ser localizado, delimitado e tratado foi o conjunto referente às 
associações de trabalhadores, em geral, de auxílio mútuo e beneficência, mas também as de resistência. Composto por estatutos das associações; relatórios de balanço feitos ao fim de cada gestão; pareceres do Conselho de Estado do Império em resposta às consultas para aprovação ou recusa de estatutos de associações; uma publicação oficial de caráter estatístico sobre assistência pública e privada na cidade do Rio de Janeiro no período imperial estendendo-se até 1912.

O segundo conjunto de fontes tratado em continuidade ao primeiro foi a imprensa operária. Jornais destinados aos trabalhadores na capital e província do Rio de Janeiro, cujos redatores se intitulavam, eles mesmos, operários, ou cuja identidade é possível inferir a partir da leitura dos periódicos. Alguns destes eram órgãos de informação e propaganda de associações abordadas aqui.

O terceiro conjunto congrega os abaixo-assinados de moradores e chefes de família de freguesias suburbanas do município neutro e da província do Rio de Janeiro requisitando ao ministério do império ou à presidência da província a abertura ou reabertura de escolas; os códices sobre escolas subvencionadas nas freguesias suburbanas do município corte; os relatórios de presidentes de província do Rio de Janeiro desde seu surgimento até o fim do império.

Por fim, o quarto conjunto é composto pelo Decreto $n^{\circ} .3029$ - de 9 de Janeiro de 1881 que reforma a legislação eleitoral, o Decreto $n^{\circ} .8213$ - de 13 de agosto de 1881 que Regula a execução da Lei n. 3029 de 9 de Janeiro do corrente ano que reformou a legislação eleitoral. Junto às legislações inserem-se artigos de jornais operários lançados imediatamente após a reforma eleitoral discutindo-a e criticando-a.

A ordem de exposição dos capítulos não segue a ordem de sua formulação. Tendo sido escrita por último, a discussão teórica aparece como abertura da tese. Neste primeiro capítulo, que não se apoia em uma série documental mais extensa, é tratado o pano de fundo do trabalho: a relação entre povo, política e educação no século XIX. Explicitando quanto o debate sobre a educação popular possuía, naquele momento, um cunho político, traz o texto da reforma eleitoral de 1881, que instituiu o critério da alfabetização para o voto, como um símbolo da institucionalização, da separação que já se processava entre instrução e experiência. Em contraponto, os artigos de periódicos operários que criticam a reforma dão a medida da resistência dos saberes daqueles sujeitos, e das suas maneiras de educar-se dentro ou fora das escolas formais.

Outras definições importantes para "início de conversa" são a concepção de classes populares que, associada à noção de classes trabalhadoras, conferem um tom mais amplo e flexível à abordagem proposta. A concepção de formação possibilita pensar uma educação que não ocorre exclusivamente na escola, mas se processa na própria vida. Por fim, a ideia de uma forma popular de fazer política, imbricada aos seus processos educacionais, que não se restringe ao voto e ao parlamento. Nesse sentido, fontes históricas já consagradas como as crônicas de João do Rio e o 
"Histórico Social" do Padeiro João Mattos, tratado pela historiadora Leila Duarte (2002), ajudam a dimensionar tais noções. Este capítulo procura apontar, ainda, uma compreensão sobre a sociedade senhorial escravista em crise, sobre as relações paternalistas, as relações entre o poder público e o poder privado naquele contexto e desenvolver teoricamente o que seriam as ideias chave de educarse e de representações de educação das classes populares.

O segundo capítulo foi o primeiro a nascer e, pode-se dizer que é a pedra angular da tese. Trata das associações de auxílio mútuo, beneficência e resistência como espaço privilegiado de aprendizagem, fazendo cruzar a história da educação e a história da formação das classes trabalhadoras no Brasil. Nesse sentido, discute uma concepção de classe apoiando-se na perspectiva dinâmica inaugurada por E. P. Thompson, para quem classes sociais não são "estruturas" e nem mesmo uma categoria, mas algo que ocorre efetivamente nas relações humanas, no processo histórico (THOMPSON, 2004, p. 9).

A caracterização dos padrões de experiência das associações pesquisadas permitiu descrevêlas sob a égide não de uma "cultura de classe", mas de "culturas de classe" com suas especificidades e heterogeneidades (BATALHA, 2004). Nesse âmbito, o educar-se das classes trabalhadoras se deu tanto nos momentos em que as associações promoveram escolas para seus sócios, filhos de sócios e mesmo para público mais amplo, em que editaram periódicos, realizaram conferências, mantiveram bibliotecas, como nas formas mais difusas de sua prática cotidiana, na participação em assembleias, elaboração e leitura de relatórios de gestão, elaboração e apresentação de balanços de contas, o próprio exercício de formulação e argumentação política com o qual se convence os outros do seu ponto de vista, a prática de resolução dos mais diversos problemas surgidos na vida coletiva.

O terceiro capítulo, sobre a imprensa operária, está intimamente ligado ao debate das associações, tanto por se tratar do mesmo recorte dentro do universo mais amplo das experiências das classes populares - aquelas ligadas ao mundo do trabalho e a identidade de trabalhador, quanto por serem os jornais operários, muitas vezes, parte da política das associações de trabalhadores, editados por elas como seus órgãos de informação e propaganda. No primeiro item é contemplada uma discussão sobre a imprensa no período e são caracterizados os periódicos utilizados. Tratou-se de um rico material para apreensão de fatos e ideias que permitiu a observação e descrição mais acabada de algumas representações de educação que circulavam entre as classes populares. Para além do conteúdo expresso em suas páginas a leitura dos jornais permitiu inferir seus efeitos pedagógicos sobre o público leitor, o que se apresenta no tópico sobre "a imprensa no educar-se das classes trabalhadoras".

O quarto e último capítulo se desprende um pouco dos anteriores no que diz respeito a 
identificação e fator de organização dos sujeitos, não mais o mundo do trabalho, mas o local de moradia. Organização episódica para a luta direta por escolarização. As classes populares reconheceram a importância do acesso ao conhecimento social e politicamente aceito conferido pela escola. A partir de então, serão levadas a cabo reivindicações por criação de escolas em localidades consideradas menos prioritárias pelos governos do município da corte e da província. Os espaços suburbanos e rurais do município da corte e demais municipalidades da província aparecem, neste capítulo, de forma mais marcante. Quando tratamos das organizações de trabalhadores e da imprensa operária, vemos configurado um espaço de atuação mais urbano. A maior parte das associações e periódicos têm suas sedes nos centros urbanos, entretanto é possível perceber que seu raio de ação era maior: associações de auxílio mútuo e beneficência aceitavam sócios e prestavam socorros a sócios em localidades relativamente distantes de suas sedes, além disso, era possível assinar grande parte dos jornais ao longo da província.

Segundo Gouvêa (2008), a proximidade geográfica da província do Rio de Janeiro com a corte da Monarquia Constitucional, legou a ela posição privilegiada politica e economicamente, pelo menos até a década de 1870. Foi pelo Ato Adicional de 1834 que se reorganizou a província e a cidade do Rio de Janeiro foi transformada em município neutro. "Até então, província e cidade vinham sendo mantidas sob a gestão do ministério do império" (GOUVÊA, 2008, p. 23). Tendo sido "laboratório" das políticas saquaremas ${ }^{7}$ para todo o império (MATTOS, 1994; GOUVÊA, 2008) foi espaço de medidas de desenvolvimento como a ligação ferroviária entre as áreas produtoras e o centro. É interessante notar que os próprios funcionários da Estrada de Ferro D. Pedro II, responsável por essa ligação, possuíam sua própria associação de auxílio mútuo.

Quanto a política educacional provincial, Fátima Gouvêa destaca que "Em 1836 a primeira Escola Normal foi criada em Niterói, resultante de um decreto do presidente da província”. Além disso, “(...) as escolas primárias sempre foram consideradas uma prioridade nos gastos públicos. $\mathrm{O}$ desenvolvimento de um programa básico educacional era mencionado frequentemente como uma das preocupações fundamentais dos deputados provinciais na Assembleia Provincial". As contradições presentes nesse processo serão discutidas a partir da ação das classes populares.

Nesse sentido, a tese abarca a província do Rio de Janeiro e o município da corte, sem deixar de levar em consideração suas diferentes realidades que implicavam em diferentes relações entre sujeitos entre si, com o mundo da leitura e escrita, bem como suas relações educacionais mais amplas. Considera, contudo, identidades entre os centros urbanos das principais municipalidades como Rio de Janeiro, Niterói e Campos que os distinguia de áreas suburbanas e rurais da corte e

7 Saquarema era o nome atribuído aos membros do Partido Conservador, em oposição aos liberais chamados luzias. O nome estava relacionado à municipalidade de Saquarema, na província do Rio de Janeiro, reduto de alguns dos seus membros mais célebres. 
demais municípios.

O capítulo aponta, por um lado, a visão das autoridades, presente nos relatórios de presidentes de província, que responsabilizavam, em grande medida, os pais dos meninos e meninas do povo pela falta de educação dos filhos, a falta de interesse pela instrução e a preferência por utilizar as crianças como fonte de trabalho e renda para a família. Por outro, mostra um clamor por escolas em diferentes regiões da província, ao que seriam oferecidas formas "adaptadas" de instrução, qualitativamente inferiores às escolas públicas de áreas centrais. Foi o caso das escolas subvencionadas, cujo caráter é discutido nesta quarta parte. O capítulo e a tese se encerram com a demonstração de como a própria luta reivindicativa por escolas foi um processo formativo, logo educativo para os moradores, chefes de família, pais de família, que pleiteando escolarização para seus filhos, ou para si mesmos logravam também educarem-se. 


\section{Capítulo 1- Povo, política e educação no século XIX}

O pior analfabeto é o analfabeto político.

Ele não ouve, não fala, nem participa dos acontecimentos políticos.

Ele não sabe que o custo de vida, o preço do feijão, do peixe, da farinha, do aluguel, do sapato e do remédio dependem das decisões políticas. $\mathrm{O}$ analfabeto político é tão burro que se orgulha e estufa o peito dizendo que odeia a política.

Não sabe o imbecil que da sua ignorância política nasce a prostituta, o menor abandonado, o assaltante e o pior de todos os bandidos, que é o político vigarista, pilantra, o corrupto e lacaio das empresas nacionais e multinacionais. (O Analfabeto Político, Bertold Brecht)

A pesquisa que gerou esta tese, na amplitude que permitem três anos de recolha documental, ou mais, se contado o trabalho em tema correlato realizado durante os dois anos de mestrado, teve como fio condutor a busca pelo papel ativo das classes populares em seu próprio processo educacional. Qual o sentido dessa busca? Por que questionar se o papel das classes populares é ou não ativo? Primeiro, por reconhecer os conflitos existentes entre os sujeitos da educação no espaço e tempo aqui estudados. Segundo, ser a educação um termo em disputa naquele contexto. Destacada no debate político sobre a civilização e a formação da nação brasileira que se tornou mais intenso partir da segunda metade do século XIX, a educação aparece como grande preocupação das nações modernas. Trata-se, na verdade, de um problema de fundo sobre governar o outro, que se desdobra na questão de educar o outro.

O fio citado à cima conduziu-nos à necessidade de entender como as chamadas classes populares experienciavam a educação. Sem aceitar como única possibilidade uma educação imposta como controle, ou oferecida como dádiva, foi preciso buscar seus meios de ensino e aprendizagem em manifestações além da escola. Ou, quem sabe, neste momento, a escola estivesse aquém de seus meios. Estes, entretanto, se relacionavam a todo instante com saberes escolarizados e com a forma escolar $^{8}$. Ao mesmo tempo, as classes populares reconheceram a escola governamental como meio de difusão de uma educação social e politicamente referendada e procuraram obter do Estado, o provimento deste bem para seus filhos ou para os adultos.

8 Para o sentido de "forma escolar" ver (VINCENT, LAHIRE, THIN, 2001), e discussão correlata sobre "maquinaria escolar" (VARELA \& URIA, 1992). 
Defendemos que esta demanda por escolas, o esforço em promover educação contando com recursos próprios (em associações, pela imprensa), bem como a construção de sua positividade simbólica, fazem parte de uma luta por educação que, pelo menos desde a segunda metade do século XIX, contribuiu para constituí-la como direito. Luta por algo que, não sendo ainda um direito social, passava a ser critério de exercício de um direito político: o voto. Apenas tardiamente, em nosso país, o analfabeto pode voltar às urnas com a constituição de 1988, porém, continua sendo inelegível. É o que consta no capítulo IV da carta magna, "Dos Direitos Políticos"”. Cada passo da presente reflexão está marcado pelo caráter político do debate educacional, por esse motivo, a abertura desta tese será feita com o esforço de compreender a relação entre classes populares, política e educação no Rio de Janeiro, entre a segunda metade do século XIX e primeiros anos do século XX.

Quem são as classes populares no contexto referido? Debate complexo será complementado com a discussão em torno da noção de classe no capítulo dois relativo ao educar-se das classes trabalhadoras em associações de auxílio mútuo, beneficência e resistência. Neste caso, uma noção de classe vinculada à identidade de trabalhador e ao mundo do trabalho, sem engessar-se nele, dialogando com outros espaços de construção de uma identidade mais complexa. Para começar, adotarei a concepção de Abreu (2003) ao realizar um pequeno histórico das apropriações do "popular" no Brasil.

No século XIX o termo "cultura popular" foi apropriado pelas elites na construção do projeto de Estado nacional independente, contrário ao projeto do colonizador. Nas décadas de 1940 e 1950 foi apropriado pelos "políticos populistas" que "jogavam" com a dicotomia entre desenvolvimento nacional versus dependência. Também as esquerdas da década de 1960 teriam se apropriado de modo diferente, utilizando a noção de popular como classe subalterna. A autora aponta como representantes destas três formas de apropriação, intelectuais do porte de Silvio Romero, Gilberto Freyre e Florestan Fernandes, respectivamente. Após a realização desse histórico, demonstra outra possibilidade de inserção no debate, pela via da história social, vinculada ao pensamento de autores como Chartier, Ginzburg, Thompson, entre outros. Estes enfatizam que não há homogeneidade entre os sujeitos ou classes de sujeitos denominados "populares", embora haja aspectos compartilhados. O fundamental seria sua contextualização histórica. Por isso Abreu (2003) afirma que "popular não se conceitua, enfrenta-se". Tratando da cultura popular ela defende que:

Há, certamente, uma posição clara, teórica e política - nada ingênua, diga-se de passagem - ao se defender a utilização da expressão cultura popular. $\mathrm{O}$ objetivo é colocar no centro da investigação as pessoas de baixa renda,

9 De acordo com a Constituição da República Federativa do Brasil: §4º São inelegíveis os inalistáveis e os analfabetos. http://www.planalto.gov.br/ccivil_03/constituicao/constitui\%C3\%A7ao.htm (Acesso em 29 de setembro de 2011). 
geralmente identificadas e discriminadas socialmente pela cor da pele, pelo local de moradia, pelo modo de ser e se vestir e pela pretensa criminalidade. No sentido político seriam os desprovidos de poder. Se podem ser tratados genericamente por populares (sem obrigação de suprimirmos as possíveis grandes diferenças entre eles, como as distinções de gênero, raça, idade, região e religião) isto deve-se ao fato de compartilharem certos aspectos, que devem ser demonstrados, tais como as condições de vida, significados de festas e danças, gostos, e de modo geral, assim serem considerados por autoridades policiais, professores, intelectuais e muitas vezes, eles próprios. (...) Cultura popular não se conceitua, enfrenta-se. É algo que precisa sempre ser contextualizado e pensado a partir de alguma experiência social e cultural, seja no passado ou no presente, na documentação histórica ou na sala de aula. O conceito só emerge na busca da maneira como as pessoas comuns, as camadas pobres ou populares (ou o que pelo menos se considerou como tal) enfrentam (ou enfrentaram) as novas modernidades (nem sempre tão novas assim), da maneira como criam (ou recriam), vivem (ou viveram) denominam, expressam, conferem, significados à seus valores, suas festas, religião e tradições, considerando sempre a relação complexa, dinâmica, criativa, conflituosa e por isso mesmo política mantida com diferentes segmentos da sociedade (ABREU, 2003, p. 94-96).

A pergunta se mantém: como esses sujeitos experienciavam a educação? Interessa apreender suas práticas e suas reflexões, considerando que a experiência nunca se dá sem pensamento (THOMPSON, 1981). Pretendemos flagrar os pensamentos que organizam suas práticas. Onde encontramos estes sujeitos? Nas associações; nas aulas noturnas; nas escolas subvencionadas; em determinadas freguesias das municipalidades onde se concentrava população pobre. Encontramonos trabalhando; lendo; escrevendo; reivindicando, inclusive escolas, por meio de abaixo-assinados; festejando; fazendo política.

Uma investigação que busca a forma pela qual as classes populares experienciaram a educação não pode deixar de conceber as relações socais que, no momento abordado, participam da própria definição daquilo que seriam as classes populares. Aqui devemos ser cautelosos como Thompson (2008) ao lembrar, para o termo "cultura popular", que este tipo de generalização universal pode esvaziar-se de sentido caso não seja colocada firmemente dentro de um contexto histórico. Para o caso da Inglaterra setecentista o autor afirma que "a cultura plebeia" não se autodefendia nem era independente de influências externas. Assumia sua forma defensivamente em oposição aos limites e controle impostos pelos governantes patrícios.

Nesse sentido, para o caso da educação popular no Rio de Janeiro oitocentista é possível estabelecer um diagrama que combina, entre conflitos e negociações, os sujeitos atuantes nessa história: as classes populares; o poder privado; e o Estado Imperial. Proponho observá-los mediatizados por relações de dádiva e direito. Trata-se de um momento em que não havia ainda uma concepção firmada de que o Estado teria o dever de prover a educação da sociedade. O que se 
via era um discurso governamental que atribuía a si o direito de formar os cidadãos de acordo com sua ordem, ou "formar o povo" segundo seus preceitos civilizatórios (MATTOS, 1994). Este discurso, porém, não correspondia diretamente a prática, quando grande parte da tarefa de instruir e educar $^{10}$ as classes populares - instrução primária para adultos ou crianças pobres - ficava a cargo de particulares individualmente ou associados e sob estratégias de baixo custo.

Entretanto a sociedade já passava a ser governada tendo a instrução e até mesmo a escola como um dado, um critério de socialização. Dessa forma, também as classes populares sentiam a necessidade de instruírem-se. Na relação conflituosa com o Estado, o principal provedor de instrução escolar, entre necessidade e negação, as classes populares tomam para si a luta pela educação de molde oficial. Enfatizo o caráter da luta por escola, porque havia, entre esses sujeitos, outras formas de educar - nos processos sociais aprendia-se fazendo, experienciando, escutando, observando. Essa maneira de ensinar e aprender não deixou de existir com o advento da escola, concorreu com ela no momento de sua instalação e persiste até hoje, mais ou menos valorizada.

Essas ações que eram diretas, coletivas ou individuais, iam desde a promoção de escolas até os próprios esforços para manter a frequência às aulas facultadas, ou ainda, reivindicativas, requisitando escolas ao Estado. Tal predisposição nos permite afirmar que a luta popular forçou a passagem da educação voltada a essa parcela da população de dádiva à direito. Lutas estas que, provavelmente, extrapolavam os limites da questão educacional e ajudavam a definir os sujeitos, antes receptores das dádivas, como interlocutores legítimos.

$\mathrm{Na}$ verdade, a própria mediação da dádiva já é em si o reconhecimento de um conflito. Ela pode ser encarada de um lado como "benevolência" e de outro representar uma conquista. A entrada do Estado nesse processo tem a ver com sua própria consolidação como poder público, regulador dos conflitos sociais. Ainda que grande parte da documentação disponível para nós veicule a imagem do homem da elite, benemérito, devotado à educação do povo, devemos ter cuidado para não adotarmos em nossas análises a autoimagem dos governantes ou de elites dominantes. É a advertência de Thompson (2008) ao discutir as relações entre patrícios e plebeus na Inglaterra préindustrial. Ele propõe, então, ver a pompa da gentry ${ }^{11}$ como encenação para o controle social, sua generosidade e caridade como cálculo de apaziguamento, os atos de doação como conquistas e até mesmo certas circunstâncias do roubo como recorrência a antigos usos do direito comum.

10 No período estudado é comum a separação entre educação e instrução como dois processos que podem estar ou não associados. A instrução estaria relacionada à uma dimensão mais “técnica” do ensino-aprendizagem. "Instrução é o que se aprende nas escolas” de acordo com o Dicionário Universal de Educação e Ensino de E. M. Campagne, 1886, citado por Francisca Isabel Pereira Maciel. Segundo ela, Campagne afirma que pode haver instrução com má educação, mas para que houvesse uma boa educação seria necessário a instrução (MACIEL, 2003). Dessa forma, a educação estaria associada a um aprendizado de caráter mais moral. Esta questão mobilizou muitos debates à época (ver SCHUELER, 1997).

11 Nobreza inglesa ligada à terra. 
Segundo Chalhoub (1990), a sociedade senhorial escravista funcionava pela produção de dependentes. Estudando os processos de liberdade nas últimas décadas de escravidão na Corte, o autor procura mostrar quão fundamental era a exclusividade do poder do senhor em conceder alforrias. A ideia era convencer os escravos que o caminho para a alforria passava necessariamente pela obediência e fidelidade a seus senhores. A dádiva maior naquele contexto - a liberdade - sob aparência de um ato voluntário, livre e gratuito, implicava tacitamente a retribuição. Havia cláusulas de prestação de serviços em muitos atos de alforria, mas essas relações extrapolavam a dimensão utilitária, produziam muitas vezes um vínculo moral ${ }^{12}$ (MAUSS, 2003).

Uma importante alteração aconteceu na ordem desta sociedade senhorial quando a legislação abolicionista passou a interpor a ação do Estado imperial limitando o poder dos senhores. Chalhoub (1990) mostra como uma série de escravos recorreram aos tribunais de justiça por sua liberdade e como a própria legislação abolicionista era fruto das lutas sociais das quais os escravos participavam. É certo que as próprias batalhas judiciais não deixaram de ser usadas por alguns curadores intencionando aproveitarem-se do trabalho dos escravos, ou que muitos "benfeitores" concediam alforrias em busca de status e vantagens políticas, ou ainda que o próprio movimento abolicionista estivesse preocupado em "evitar a ação direta dos negros porque isso implicava ver: uma classe, e essa a mais poderosa e influente do Estado exposta a vindita bárbara e selvagem de uma população mantida até hoje no nível dos animais e cujas paixões, quebrando o freio do medo não conheceriam limites no modo de satisfazer-se" (CHALHOUB, 1990, p. 172). Porém, foi possível perseguir os significados da liberdade para escravos e libertos, e dessa maneira o autor logrou reformular as teses sobre a transição do trabalho escravo para o trabalho livre no Brasil rompendo com a linearidade e previsibilidade.

O mesmo princípio de capacidade de ação dos sujeitos em posição de dominação é usado na análise das relações entre os patriarcas e dependentes feita por Chalhoub (2003) a partir da leitura das obras de Machado de Assis em Machado de Assis Historiador. Novamente ele propõe uma interpretação alternativa das dádivas pela visão de quem as recebia. Os dependentes não seriam

12 Em seu Ensaio Sobre a Dádiva, Marcel Mauss produz o estudo clássico sobre o direito contratual e os sistemas das prestações econômicas de que se compõem as sociedades ditas primitivas. O sociólogo mostra como tais sociedades organizam-se a partir desse valor que não é apenas econômico, mas moral e até místico de que a dádiva trazia consigo a necessidade de retribuição dos presentes. Ele analisa, ainda, a presença da dádiva nas sociedades indoeuropeias antigas (Roma, Índia, Germânia) e apresenta aí a transição entre aquele sistema arcaico e o contrato individual. Entretanto, o próprio Mauss afirma que em nossa moral contemporânea ainda se mantém uma atmosfera em que dádiva, obrigação e liberdade se misturam. Algumas passagens do ensaio podem nos iluminar ideias sobre a dádiva como forma de controle social nas relações entre classes populares e elites nas últimas décadas do oitocentos. "Em todas essas sociedades as pessoas se apressam em dar, sob pena, ao menos para os nobres, de perder sua posição social. (...) Ao aceitá-lo, porém, a pessoa sabe que se compromete. Recebe-se uma dádiva como 'um peso nas costas'. Faz-se mais do que beneficiar-se de uma coisa ou de uma festa, aceitou-se um desafio, e pôde-se aceitálo porque se tem certeza de retribuir, de provar que não se é desigual” (MAUSS, 2003, p. 248). Ou ainda: "[O vínculo que a dádiva estabelece entre donatário e o doador é demasiado forte]. $\mathrm{O}$ donatário coloca-se na dependência do doador" (MAUSS, 2003, p. 286). 
seres passivos. É o caso da perspicaz interpretação do romance Helena. Nele, Machado teria levado a pensar, pela forma como constrói a protagonista, que os dependentes, na sociedade senhorial possuíam uma visão de mundo que lhes era própria e não pode ser entendida se referida apenas à ideologia senhorial. Helena, representando os dependentes, acabava por usar sua esperteza para levar Estácio, representante da classe senhorial, a agir em favor dela, acreditando o moço que seguia exclusivamente a própria vontade.

Helena sabe que no mundo ideal de Estácio, coisas e pessoas aparecem apenas como expressão da vontade dele, e logo o rapaz e seus seguidores gostam de se imaginar controladores de uma espécie de economia de concessão de favores. Helena também sabe quanto essa visão unilateral do mundo encerra de arbítrio e solução violenta de conflitos (CHALHOUB, 2003, p. 26).

Em uma situação de desvantagem na correlação de forças, tais espertezas eram formas das classes populares conseguirem certos objetivos sem recorrer à luta aberta, onde teriam menos chances de sobrevivência. É o caso de Helena e o caso de "um sem número de dependentes". Mas era também uma forma das classes dominantes evitarem a mesma "luta aberta", evitando a possibilidade, aberta pelo "acaso da luta" (FOUCAULT, 2003) de conquistas dos dominados. Assim, cada conquista dos dominados foi representada pelos dominantes como concessão sua ${ }^{13}$.

A história de Estácio e Helena é a descrição do período de hegemonia inconteste da classe senhorial escravista cuja crise profunda o romancista vivenciou entre 1866 e 1871 e cujo desmanchar ele assistia com olhar investigativo no decorrer da década de 1870.

A ambiguidade da personagem principal traduzia uma experiência histórica de um sem número de dependentes nesse tempo e sociedade: ainda seduzidos de alguma maneira pela ideologia senhorial, Helena e seus semelhantes podiam mostrar-se sinceramente gratos a seus benfeitores específicos, e assim permaneceriam relutantes em sacudir a inércia das estruturas tradicionais de poder, outrossim, os anos de crise haviam agudizado a perspectiva crítica mais geral explicitando as injustiças inerentes à política de domínio senhorial..." (CHALHOUB, 2003, p. 42).

13 A obra infanto-juvenil de Antoine de Saint-Exupéry se apresenta, de forma lúdica, como um exemplo da atitude de Estácio e das classes dominantes em um regime de relações paternalistas. Trata-se do Rei que habitava o primeiro planeta visitado pelo Pequeno Príncipe. Assim que viu o menino, o Rei, sentado em seu trono simples, posto que majestoso, exclamou: "Ah! Eis um súdito". Ao que o príncipe questionou: "Como pode ele conhecer-me se jamais me viu". Com bom senso, o narrador afirma: "Ele [o menino] não sabia que para os reis, o mundo é muito simplificado. Todos os homens são súditos" (SAINT-EXUPÉRY, 1983, p. 37). Logo, o menino começou a observar de que forma subsistia a autoridade do Rei. Tendo viajado sem dormir, ele começou a bocejar ao que foi repreendido: “- É contra etiqueta bocejar na frente do Rei, disse o monarca. - Eu o proíbo. - Não posso evitá-lo, disse o principezinho confuso. - Fiz uma longa viagem e não dormi ainda... - Então eu te ordeno que bocejes. Há anos que não vejo ninguém bocejar! Os bocejos são uma raridade para mim. Vamos, boceja! É uma ordem! - Isso me intimida... eu não posso mais, disse o principezinho, todo vermelho. - Hum! Hum! Respondeu o Rei... então eu te ordeno que ora bocejes e ora... Ele gaguejava um pouco e parecia vexado. Porque o Rei fazia questão fechada que sua autoridade fosse respeitada. Não tolerava desobediência. Mas, como era muito bom, dava ordens razoáveis. "Se eu ordenasse, costumava dizer, que um general se transformasse em uma gaivota, e ele não o fizesse, a culpa não seria do general, seria minha" (SAINT-EXUPÉRY, 1983, p. 37 e 38). 
Inspirada na perspectiva de Chalhoub sobre o papel dos escravos e libertos nas lutas pelo fim da escravidão, quando afirma que seu "objetivo principal foi recuperar alguns aspectos da experiência dos escravos na Corte, de seus modos de pensar o mundo e atuar sobre ele" (CHALHOUB, 1990, p. 251) me proponho a buscar as "visões da educação" das classes populares, entre elas, principalmente trabalhadores livres, escravos e libertos, no Rio de Janeiro do fim dos oitocentos. Apropriando-me de um dos referencias que impregnam a obra o próprio Chalhoub, poderia dizer que busco um educar-se $e^{14}$ ou o fazer educacional das classes populares nesse contexto.

Compreender os significados da educação para as classes populares oitocentistas, ou suas representações de educação (CHARTIER, 1991) dependia da recuperação mais sistemática da experiência desses sujeitos. Movimento de ideia correlato ao que fez Chalhoub, ao procurar entender quais os sentidos da liberdade para os escravos, o esforço foi de interpretar os sentidos da educação sem se prender àqueles inventados para as classes populares por elites intelectuais e dirigentes do Estado da época (CHALHOUB, 1990, p. 80).

É interessante observar um dos usos da educação, certamente, dos menos comuns, presente no texto do mesmo autor. Em 1849, havia na Corte, 10.732 libertos que deixavam as autoridades em alerta, atentas aos movimentos dos negros, por temor de rebeliões de escravos como na Bahia. "Em ofício de 27 de março de 1835 ele [Euzébio de Queirós, chefe de polícia] determinou ao juiz de paz do distrito de Santana que investigasse uma casa na Rua Larga de São Joaquim 'na qual há reuniões de pretos minas a título de escola de ensinar a ler e escrever"' (CHALHOUB, 1990, p. 187). Assim, procuravam vigiar e proibir qualquer "ajuntamento" de negros.

Uma das circunstâncias da escola é, de fato, juntar pessoas em um mesmo espaço e momento, muitas delas de extração social comum, portadoras de problemas e interesses, por vezes, comuns. Isso pode não querer dizer nada em termos de associação para ações conjuntas, quanto menos para articulação das revoltas temidas pelas autoridades da Corte, mas também é possível que a escola viesse a ser um polo de agregação do grupo. Uma segunda percepção do ofício citado por Chalhoub é de que aqueles sujeitos, independente de sua própria visão de educação, compreendiam o sentido hegemônico atribuído a essa prática: positiva, moralizadora, pacífica, ótima "fachada" para sua organização proibida. Se Euzébio de Queirós interpretou corretamente os objetivos das reuniões dos pretos minas, podemos afirmar que, ao tomarem as aulas de ler, escrever e contar como pretexto, teriam de fato entendido o sentido hegemônico da educação enquanto subvertiam

14 Tento adotar a concepção de E. P Thompson ao tratar da formação da classe operária inglesa, sua ideia de Making off the english work class, traduzida como "formação" remete a um fazer-se porque, segundo o autor "é um estudo sobre um processo ativo, que se deve tanto à ação humana quanto aos condicionamentos" (THOMPSON, 2004, p. 9). 
sua lógica.

Em função dos propósitos desta tese, a concepção de educação aqui adotada será ampla, ainda que, ao longo de nossa história, ela tenha se tornado, praticamente, sinônimo de escola. Do que decorre o que Miguel Torga considerou como “(...) a desgraça de o povo saber de uma maneira e as escolas saberem de outra. Acabando o exame de quarta classe, cada qual trata de sepultar sob uma leiva, o mais depressa que pode, a ciência que aprendeu"' (NOVOA, 2000, p. 3). Para Nóvoa, no prefácio ao livro Educação de Adultos. Um campo e uma problemática, de Rui Canário, o modelo escolar imposto às formas tradicionais de aprendizagem e transmissão cultural ao longo do século XIX, tornou nítida a distinção escola e vida. "Cada um à sua maneira, desejava terminar a escola, para nunca mais voltar lá" (NÓVOA, 2000, p. 4). Porém, subsistiria outro processo, que aqui nos interessa mais de perto, o da formação. Este não se deixaria controlar facilmente, acontecendo mais vezes quando não esperamos do que quando o programamos. "Formação não é algo que se possa fazer num lugar a parte. Bem pelo contrário, é um processo que se confunde com a própria vida" (NÓVOA, 2000, p. 5).

A obra de Canário (2000) prefaciada por Nóvoa, a cima citada, conta a história da educação de adultos em Portugal. Os debates sobre educação de jovens e adultos estão entre os mais característicos e os mais desenvolvidos no campo da educação popular. Na verdade, durante determinado período, chegou-se mesmo a confundir os termos "educação popular" e "educação de adultos", especialmente a "alfabetização de adultos". Estes debates nos ajudam a pensar a questão dos saberes de experiência aqui perseguidos.

Segundo Canário, a educação popular teria emergido historicamente “(...) a partir do século XIX, associada a dois grandes processos sociais: por um lado os movimentos sociais de massa (movimento operário) que estão na raiz da vitalidade da educação popular, por outro lado o processo de formação e consolidação dos sistemas escolares nacionais que conduziu à emergência de modalidades de ensino de segunda oportunidade" (CANÁRIO, 2000, p. 12). Em meio a esses dois processos encontramos, no Rio de Janeiro oitocentista, as reivindicações de "chefes de família" ou "pais de família" por educação estatal, bem como um sem número de iniciativas da sociedade civil não necessariamente ligadas a um movimento operário organizado. A presente tese procurou se ater, por um lado, às ações reivindicativas por escola, direcionadas ao governo, em povoações de freguesias rurais e suburbanas da província do Rio de Janeiro e Corte. Por outro lado, às ações do movimento de trabalhadores nas últimas décadas dos oitocentos e início do século XX, parte do processo de formação da classe.

No bojo deste debate, Canário descreve "três níveis de formalização educativa" dos quais o terceiro, cuja abordagem é menos usual na área de história da educação, interessa mais de perto ao 
desenvolvimento desta tese. O primeiro nível seria o formal de que o protótipo é o ensino dispensado pela escola, com base na assimetria professor aluno, na estruturação prévia de programas e horários, na existência de processos avaliativos e de certificação; O segundo seria não formal caracterizado pela flexibilidade de horários, programas e locais, baseado geralmente no voluntariado, em que está presente a preocupação de construir situações educativas à medida de contextos e públicos singulares. É justamente no campo da educação de adultos, em regra mais ativamente refratários a processos escolarizados, que essas modalidades se tem vindo desenvolver; Finalmente, um nível informal que corresponde a todas as situações potencialmente educativas, mesmo que não conscientes, nem intencionais, por parte dos destinatários, correspondendo a situações pouco ou nada estruturadas e organizadas.

No contexto estudado, o primeiro e o segundo níveis se confundiam, pois a forma escolar estava em processo de implantação. Logo, o que era formal ainda não estava tão bem delimitado, nem constituía um sistema homogêneo que pudesse identificar outra ação não formal por oposição. Consideramos, porém, que o terceiro nível, da educação informal, era perceptível e, desde então, distinguia-se dos dois primeiros. Cabe apresentar, apoiada na mesma obra de Canário (2000) uma definição de educação informal que nos ajudará a compreender o sentido das ações educativas estudadas nos capítulos seguintes.

A educação informal correspondeu, até um passado recente, a uma face não visível do icebergue educativo, cuja 'face visível' correspondente ao universo escolar, nos permite aceder, apenas, a uma visão truncada e incompleta do processo educativo, definido em termos organizacionais, e balizado por programas, certificados e sessões (Dominicé, 1990). O acesso às 'faces ocultas' do processo educativo, isto é aos informais, implica estabelecer uma ruptura com a definição de situação educativa que produz os traços do modelo escolar, nomeadamente a questão da intencionalidade (CANÁRIO, 2000, p. 79-82).

Abraham Pain (1990, apud CANÁRIO, 2000, p. 79-82) propõe uma inversão nas definições tradicionais de situações educativas, qualificando-as não a partir das intenções dos intervenientes, mas sim de seus efeitos educativos ${ }^{15}$. O que levaria em conta a amplitude de situações cotidianas que produzem tais efeitos. Estas são tantas que corresponderiam "à maior fatia das aprendizagens realizadas pelos indivíduos" (CANÁRIO, 2000, p. 79-82). O exemplo oferecido por Guy Berger (1991, apud CANÁRIO, 2000) é bastante familiar ao tema do capítulo seguinte, onde será apresentada a experiência do educar-se da classe trabalhadora em suas associações.

(...) um exemplo muito claro de como aquilo que "a vida ensina" pode revelar-se mais decisivo para a concretização de novas aprendizagens do que o percurso escolar, traduzido pela certificação em diplomas: Por

15 Esta noção de "efeito educativo" será retomada no capítulo que trata da educação para as classes trabalhadoras e populares a partir da imprensa operária. 
exemplo, animar uma reunião, isso obriga a usar a palavra, ler documentos, a ler textos e demo-nos conta, na minha universidade que o prognóstico de sucesso universitário era muito mais favorável para alguém que tivesse parado os estudos na escola primária, mas que tivesse animado uma associação por dez anos, do que para alguém que tivesse concluído o "bacalauréat" com uma menção "bien". A experiência de usar a palavra, da leitura dos textos, da retórica pela qual convencemos o outro da nossa razão, são evidentemente mais significativos em termos de sucesso que tal ou tal atividade escolar" (CANÁRIO, 2000, p. 112 e 113).

\section{1- Saberes que a vida ensina}

Ao longo do desenvolvimento dessa tese, tive a chance de revisitar algumas crônicas do jornalista e escritor carioca de fins do século XIX e início do XX, João do Rio, com as quais já havia tido contato em outra ocasião. Resolvi tomá-las como material bastante representativo, para o período aqui abordado, daquilo que "a vida ensina". Esses saberes difusos foram captados pelo autor quando procurou apreender o cotidiano da cidade saindo às ruas do Rio de Janeiro, entre as últimas décadas do século XIX e as primeiras do século XX. Escrita jornalística de caráter literário nos fornece ricos elementos sobre uma existência tão difícil de apreender nas fontes oficiais. Quem busca da experiência educacional das classes populares pode encontrar cocheiros, estivadores, marinheiros, construtores de presépios, leitores e pintores em seus momentos de trabalho ou lazer, que não deixam de ser ocasiões de reflexão e produção de conhecimentos, tão bem captadas pelo cronista nos diálogos travados com esses sujeitos.

Além da adequação temporal e dos personagens trazidos às páginas por João do Rio, o formato de crônicas oferece ao historiador rico material associativo de fatos cotidianos e ideias do período de alguma forma expressas pelo autor. Mas, longe de ser mero reprodutor de ideologias importadas, circulantes nos meios intelectuais, João do Rio impôs sua marca, expressão de suas contradições. Segundo Raul Antelo (1997) em sua introdução à Alma Encantadora das Ruas, obra literária que reúne as crônicas de João do Rio publicadas pela imprensa carioca entre 1904 e 1907 , aqueles textos são uma janela aberta para o avanço da modernidade e de uma vida urbana de forte dimensão visual. Por ela observa o processo de remodelação da capital, as reformas civilizatórias que pretendiam, sob o modelo de Paris, transformar o Rio de Janeiro em "vitrine do Brasil". Processo que se realizaria a custa de repressão e expulsão das classes populares do centro da cidade. Atento às margens da acumulação de capital, João do Rio expressa em sua produção conflitos sociais em parte também experimentados por ele.

“Era gordo, mulato, homossexual”. Um autor que estava “à margem” em certas dimensões, 
mas "submisso ao stablishment" (ANTELO, 1997, p. 20 e 28). Sua posição de fronteira parece ter lhe facultado a sensibilidade para captar a vida da "gente comum" e também dos tipos pitorescos que vivem em meio às massas. Sensibilidade que em muitos momentos sucumbe a preconceitos de homem de seu tempo, algumas vezes dirimidos no momento em que, indo às ruas, questionava, deixava falar, escutava seus personagens: estivadores, artistas, cocheiros, presidiários, entre outros, humanizando suas representações em esporádicos impulsos antropológicos.

Agripino Grieco pinta um retrato de João do Rio que pode nos servir como uma introdução inspiradora para leitura de suas crônicas.

Nesse homem que vestia camisas de seda de duzentos mil réis, fazia encomendas diretas aos alfaiates de Londres e que quando se banhava em água de Colônia era como se se banhasse em água de Juvena, existia uma alma de garoto mexeriqueiro, dos que tomam traseira de bonde, apanham pontas de cigarros à beira da sarjeta e alongam um palmo de língua vermelhíssima para os policiais inimigos. Era de vê-lo deixar o asfalto da Avenida e as montras da Rua do Ouvidor e ir meter-se pelos becos ladeirentos da Saúde ou pelos atalhos de São Cristóvão, farejando casos de exceção, tipos de exceção. Os estivadores tatuados de hieróglifos e as costureirinhas líricas que põe o vaso de manjericão na varanda ou penduram à janela a gaiola do canário (ANTELO, 1997, p. 24).

Das vinte e oito crônicas publicadas em A alma encantadora das ruas sete delas nos dão mais ricos testemunhos sobre os saberes informais, informalmente adquiridos e produzidos pelas classes populares. Referimo-nos as seguintes: Os tatuadores; Os mercadores de livros e a leitura das ruas; A pintura das ruas; Tabuletas; Velhos cocheiros; Presepes; e Os trabalhadores da estiva; todas bastante sugestivas desde seus títulos. Atenta ao filtro posto pelo próprio registro e posicionamento do cronista, procurei captar nelas as nuances do cotidiano dos sujeitos retratados em seus momentos de trabalho, de rituais ou de reflexão.

Ao nos deixarmos "flanar" por essas ruas, levados pelas mãos do cronista, podemos nos deparar com os tatuadores. João do Rio abre a crônica de onze de novembro de 1904, estampada na revista Kosmos, com a atitude de um "petiz" de prováveis doze anos que com ar de dignidade, roupa em frangalhos e os pés nus, pergunta a um rapazola loiro sentado a uma porta:

Quer marcar?

(...)

Por quanto?

É conforme - continuou o petiz. _É inicial ou coroa?

É um coração!

Com nome dentro?

O rapaz hesitou. Depois:

Sim, com nome: Maria Josefina.

Fica tudo por uns seis mil réis. (ANTELO, 1997, p. 100 e 101) 
O que temos aí é essencialmente um uso popular da escrita. Escrever no corpo era uma arte praticada, naquele momento, por pessoas pobres. Ao perguntar ao cliente se "queria marcar" o coração com nome dentro, o menino nos mostra que conhecia a escrita. Aquele pequeno que escrevia em tão nobre suporte, é flagrado em seu ofício num período alarmado pelas estatísticas. Ao apontar uma taxa de analfabetismo de aproximadamente $82,5 \%$ da população, os censos de 1872 e 1890 ofereciam matéria prima para, distorcidos em sua interpretação, pintar um cenário de ignorância e barbárie sempre atribuída "ao povo".

Não se trata de negar os números, mas de atentar para os devidos cuidados que o historiador deve ter com eles. Essa mesma questão recebeu a atenção de E. P. Thompson. Uma de suas constantes críticas é feita à metodologia quantitativa. $\mathrm{O}$ quantitativismo inviabilizaria sua proposta de compreensão da história a partir da experiência, do fazer das classes populares ou, como a historiografia consagrou a partir deste autor, uma compreensão a partir "de baixo". À metodologia quantitativa não deve ser permitido permanecer ilesa quando elimina (como "literário" ou "atípico") inteiras categorias de evidência.

De fato, homens e mulheres pobres e trabalhadores eram os mais penalizados com a falta de acesso à leitura e escrita, ou mais precisamente, com sua exclusão dos mais altos graus de desenvolvimento institucional da educação (permanência na vida escolar). Entretanto, não se deve concluir por seu total alijamento desse universo, muito menos associar essa condição a menores níveis de desenvolvimento intelectual ou cultural. É preciso permitir-nos enxergar outros usos, significados e materialidades para essa leitura e escrita populares de fins do oitocentos e início do XX.

Da tatuagem no Rio faz-se o mais variado estudo da crendice. Por ele se reconstrói a vida amorosa e social de toda a classe humilde, a classe dos ganhadores, dos viciados, das fúfias de porta aberta, cuja alegria e cujas dores se desdobram no estreito espaço das alfurjas e das chombergas, cujas tragédias de amor morrem nos cochicholos sem ar, numa praga que se faz de lágrima. A tatuagem é a inviolabilidade do corpo e a história das paixões. Esses riscos nas peles dos homens e das mulheres dizem as suas aspirações, as suas horas de ócio e a fantasia de sua arte e a crença na eternidade dos sentimentos - são a exteriorização da alma de quem os traz. (ANTELO, 1997, p. 102 e 103)

Trata-se de uma escrita das classes populares para elas mesmas, desafiando a concepção de que a técnica estaria necessariamente ligada ao controle e dominação. A escrita sobre o corpo é usada por homens e mulheres humildes, à margem da sociedade, como forma de contar suas histórias quando, talvez, não tivessem outro suporte para isso. Sujeitos de quem muitas vezes não se reconhecia a humanidade e individualidade buscavam expressar pela arte gráfica suas emoções, aspirações, pertencimentos. 
E, antes de pensarmos que a escrita popular representada aqui pelos tatuadores se realizasse apenas como grafia e não como sentido, observemos a crônica sobre Os mercadores de livros $e$ a leitura das ruas publicada na Gazeta de Notícias em 12 de fevereiro de 1906. É interessante perceber a considerável difusão da leitura em diferentes espaços desde as casas de detenção, até entre "caixeiros de botequim, rapazes do povo, dos vadios, do grosso, enfim, da população" (ANTELO, 1997, p. 144). É preciso registrar que não havia uma ligação inerente entre saber ler e saber escrever, e mais importante ainda, entre o "ato léxico" e o "ato escriturístico" da leitura. O que implica em que a decifração do sentido não signifique, necessariamente, decifração do código, alçando o ler para além da identificação dos sinais gráficos e o reconciliando com a oralidade. Segundo Certeau

... as pesquisas consagradas a uma psicolinguística da compreensão distinguem, na leitura, "o ato léxico" do "ato escriturístico". Mostram que a criança escolarizada aprende a ler paralelamente à sua aprendizagem da decifração e não graças a ela: ler o sentido e decifrar as letras correspondem a duas atividades diversas, mesmo que se cruzem. Noutras palavras, somente uma memória cultural adquirida de ouvido por tradição oral, permite e enriquece aos poucos as estratégias de interrogação semântica cujas expectativas a decifração de um escrito afina, precisa ou corrige. Desde a leitura da criança até a do cientista, ela é precedida e possibilitada pela comunicação oral, inumerável autoridade que os textos não citam quase nunca (CERTEAU, 1994, p. 263).

Seguindo em suas andanças pela cidade, nosso cronista encontra, na esquina do Teatro São Pedro, o italiano Arcanjo, dono do ponto em que vendia jornais e livros havia dez anos. Lhe desperta a curiosidade aquela "biblioteca popular".

Havia algumas patriotadas, a Questão da Bandeira, a D. Carmem de B. Lopes, a Vida do mercador e de Antonio de Pádua, o Evangelho de um triste e os Desafogos líricos. Estavam em exposição, cheios de pó, com as capas entornadas pelo sol.

Vende-se tudo isso?

Oh! Não. Há quase um ano que os tenho. Os outros sim: modinhas, orações, livros de sonhos, a História da Princesa Mangalona, o Carlos Magno, os testamentos dos bichos...

Levantei as mãos para o céu como pedindo testemunho do alto. As obras vendáveis ao povo deste começo de século eram as mesmas devoradas pelo povo nos meados do século passado! (ANTELO, 1997, p. 136 e 137).

Ler é um exercício de memória cultural. As obras vendáveis ao povo no início do século XX eram as mesmas de meados do XIX. O tipo de literatura apreciada é aquele condizente com uma cultura há muito estabelecida, uma cultura de crença, de misticismo, além dos títulos que refletiam a busca pelo lúdico no exercício da leitura. É importante reter que, certo interesse das classes populares pela leitura não fora uma novidade do século XX. É importante comentar que esse tipo de 
leitura não estava presente nas salas de aula.

As livrarias vendem baratíssimo os livrecos procurados. Em cada um, os vendedores ganham, no mínimo, seiscentos por cento. Há alguns que, trabalhando com vontade e sabendo lançar - as orações, as modinhas ou a infalível História da Donzela Teodora, arranjam uma diária de dez mil réis sem grande esforço. Daí todo dia aumentar o número de camelôs de livros, vir começando a forma-se essa próspera profissão da miséria que todas as cidades têm... (ANTELO, 1997, p. 139)

Havia, pois, uma demanda por livros que não deve ter surgido de uma hora pra outra nos primeiros anos dos novecentos. Demanda explorada por um mercado que ao tornar mais acessível o impresso, ajuda a difundir ainda mais a cultura escrita formando, assim, novos possíveis compradores. Sendo bom de vendas, "sabendo lançar" as obras do gosto do povo, o camelô de livros poderia prosperar, segundo o cronista. Poderia prosperar ainda que analfabeto, caso do Arcanjo, a que voltaremos adiante.

Diversos eram os sujeitos leitores bem como as formas de ler:

Essa literatura, vorazmente lida na Detenção, nos centros de vadiagem, por homens primitivos, balbuciada à luz dos candeeiros de querosene nos casebres humildes, piegas, hipócrita e mal feita, é a sugestionadora de crimes, o impulso à exploração de degenerações sopitadas, o abismo para a gentalha. Contam na Penitenciária que o Carlito da Saúde, preso a primeira vez por desordens, ao chegar ao cubículo mergulhou na leitura do Carlos Magno. Sobreveio-lhe uma agitação violenta. Ao terminar a leitura anunciou que mataria um homem ao deixar a Detenção. (ANTELO, 1997, p. 140 e 141)

Esta relativa difusão da leitura entre "homens primitivos" parece causar certo incômodo ao cronista. Leitura contraventora, "balbuciada à luz de candeeiros de querosene nos casebres humildes", onde não seria seu lugar. Talvez por tratar-se de produção de baixa qualidade "piegas, hipócrita e mal feita", sob a lógica do mercado, para agradar homens e mulheres de gosto bárbaro. Imbuído, provavelmente, da concepção de que o texto determina a leitura (CERTEAU, 1994), ele se ressente do perigo representado pelo efeito da literatura de baixo calão no comportamento social daqueles seres inferiores, destituídos do poder de julgamento.

Ainda afirmando a centralidade da escrita e leitura para a vida da gente comum do meio urbano no início do século XX, temos a crônica sobre as Tabuletas, em Gazeta de Notícias de 27 de março de 1907.

E na rua, que se vê? O senhor do mundo, o reclamo. (...) Quantas [tabuletas] haverá no Rio? Mil, duas mil, que nos fazem rir. Vai um homem num bonde e vê de repente, encimando duas portas em grossas letras essas palavras: Armazém Teoria.

Teoria de que, senhor Deus? Há um outro tão bizarro quanto este: Casa Tamoio, Grande armazém de líquidos comestíveis e miudezas. Como saber 
que líquidos serão esses comestíveis, de que a falta de uma vírgula fez um assombro? (...)

E se não vos bastar um café tão completo, aí temos um mais modesto na rua da Saúde o Café BTQ. E sabem o que vem a ser o B.T.Q., segundo o proprietário? Botequim pelas iniciais! Essa nevrose das abreviações não atacou felizmente o dono da casa de pasto na rua de São Cristóvão, que encheu as paredes com as seguintes palavras: Restaurante dos Dois Irmãos Unidos Por...

Unidos por... Pelo quê? Pelo amor, pelo ódio, pela vitória? Não! Unidos Portugueses. Apenas faltou a parede e ficou só o Por... (ANTELO, 1997, p. 158).

O mesmo tom de crítica feita às leituras populares aparece aqui numa postura irônica do intelectual de classe média ao cobrar correção gramatical à inscrição do nome do armazém na tabuleta. Seria interessante poder ouvir dos donos de BTQ ou de Irmãos unidos por suas representações, intencionalidades e justificativas para os nomes de seus estabelecimentos. Em todo caso, ao chamar-nos a atenção para as tabuletas, o autor desenha uma cidade onde o código escrito se fazia presente no espaço público, diferentes suportes imagináveis para as leituras populares.

Como já foi aqui mencionado, João do Rio expressa em seus escritos, percepções contraditórias sobre as classes populares cariocas e seus costumes. Ao mesmo tempo em que os "deplora", os escuta e relativiza seu próprio posicionamento reconhecendo naquelas pessoas, capacidade de elaboração intelectual tanto artística quanto política e filosófica. Ao ser levado por um amigo a conhecer $A$ pintura das ruas, título de sua crônica de 28 de julho de 1907 publicada pela Gazeta de Notícias, o jornalista fica pasmo.

Os pintores anônimos, os pintores da rua, os heróis da tabuleta, os artistas da arte prática. É curiosíssimo. Há lições de filosofia nos borrões sem perspectiva e nas botas sem desenho. Encontrarás a confusão da populaça, os germes de todos os gêneros, todas as escolas e por fim, muito menos vaidade que na arte privilegiada. (...)

Quantos pintores pensa a cidade que possui? A estatística da Escola é falsíssima. Em cada canto de rua depara a gente com a obra de um pintor, cuja existência é ignorada por toda a gente (ANTELO, 1997, p. 147 e 148).

Com tom entusiasmado segue mostrando o que "A Escola" pouco reconheceria. Que os pintores das ruas têm um ponto de vista próprio no que diz respeito a seu trabalho e ainda ao representarem pela arte os assuntos públicos. Coloca no mesmo patamar a pintura das ruas e a das galerias, eleva a pintura popular à condição de arte.

É, entretanto, nas crônicas sobre Velhos cocheiros (sem data), Presepes (Gazeta de Notícias, 11/01/1905) e Os trabalhadores da estiva (Gazeta de Notícias, 19/06/1904) que mais se explicita a capacidade das classes populares elaborarem suas visões de mundo a partir de sua vivência, ainda que, como aponta Thompson, haja aí uma ambiguidade na consciência. 
Assim as 'duas consciências teóricas podem ser vistas como derivadas de dois aspectos da mesma realidade: de um lado a conformidade com o status quo, necessária para a sobrevivência, necessidade de seguir a ordenação do mundo e de jogar de acordo com as regras impostas pelos empregadores, os fiscais dos pobres, etc. De outro lado o 'senso comum', derivado da experiência da exploração, dificuldades e repressão compartilhada com os companheiros de trabalho e os vizinhos, que expõe continuamente o texto do teatro paternalista à crítica irônica e, com menos frequência, à revolta (THOMPSON, 2008, p. 21).

É o que podemos perceber na conversa que João do Rio tem com Braga, velho cocheiro, na profissão desde 1870 .

E não estás rico?

Rico?

Soltou uma gargalhada sonora que lhe balançou o ventre e o envermelheceu mais. Os seus olhos pequenos olhavam-me da boléia com superioridade compassiva. (...) O ofício, longe de tornar ágeis os corpos, faz lesões cardíacas, atrofia as pernas, hipertrofia os braços, de modo que quinze anos de boléia, de visão elevada do mundo, ao sol e à chuva, estragam e usam um homem como a ferrugem estraga o aço mais fino. (...)

Eu continuava a ouví-lo. Naquela boléia falava um cultor do quietismo, um renanista que tivesse compreendido o nirvana. Nem uma ambição, nem um ódio, apenas um sorriso de quem não se rala com a vida e vem para a rua almejando não encontrar fregueses, para dormir mais a vontade.

Ah! Este carro! - murmurei. Quanta história podia você contar! Quantas cenas de amor, quantos beijos, quantas angústias e quantos crimes!...

Este carro não; outros, ou antes, eu. Fui de cocheira; fui de casa particular e trabalhei por minha conta. Quando caiu o ministério João Alfredo fui eu quem o levou ao Paço. Agora, essas coisas de beijos, noutro tempo era nas berlindas.

Tinha vontade de saber sua opinião.

Ele arregalou muito os olhos:

A respeito de beijos? Sei lá!

Não, a respeito da Monarquia e da República.

Ele sorriu, pensou.

A Monarquia tinha as suas vantagens. Era mais bonito, era mais solene. Não vá talvez pensar que eu sou inimigo da República. (...) Bom tempo aquele. Hoje a gente tem de suar pra conhecer um ministro. Parecemse todos com os outros homens. (...) depois, quer saber, a República trouxe a Bolsa, uma porção de cocheiros estrangeiros, uns gringos e ingleses de cara raspada, com uns carros que nem eu lhes sabia o nome! (ANTELO, 1997, p. 190 a 193).

Comecemos pelo sarcasmo do Braga. O velho não gasta páginas em um artigo de sociologia, mas em sua gargalhada quando perguntado se depois de tanto tempo de trabalho não ficara rico, pode nos dizer como pensava a respeito das relações de trabalho por ele vivenciadas e o problema da exploração. Em seu olhar de superioridade em cima da boléia, ainda promove uma subversão no 
diálogo entre o jornalista que "deveria saber das coisas" e ele um "trabalhador ignorante". Afirma assim dignidade e orgulho de trabalhador experiente em seu ofício pela sabedoria alcançada em longa vivência que lhe deixara marcas no próprio corpo.

João do Rio reconhece em Braga um homem que desenvolvera uma compreensão mais profunda da vida e uma filosofia adequada à si. Era portador de histórias e possuía consciência do que tinha para contar, valorizando sua própria experiência pelos momentos passados ao lado de pessoas ilustres da sociedade carioca. Pedida sua opinião, faz galhofa, "A respeito de beijos? Sei lá!”. Mas logo expressa seus posicionamentos políticos sobre os regimes de governo. Seguisse ele o estereótipo sobre o homem do povo poderia ter ficado calado, simplesmente ter alegado que nada sabia.

Porém responde com o cuidado de um cálculo político ao não se declarar publicamente a favor da República ou da Monarquia reconhecendo-se na posição vulnerável de homem do povo em meio a um debate ainda candente: "Não vá talvez pensar que eu sou inimigo da República". Entretanto, não se furta à crítica do novo regime, tendo como matéria a experiência cotidiana de um aspecto prejudicial a si: no governo republicano não se reconhece mais quem são os membros, já que não se distinguem por vestimentas e outros símbolos usados pelo Império. Parece considerar que a política teria se afastado ainda mais do povo, embora não ache adequado que os políticos se confundam com os cidadãos comuns. Além disso, "a República trouxera a Bolsa e uma porção de cocheiros estrangeiros" e com eles a concorrência.

Da mesma forma que fora a campo procurar os velhos cocheiros, nosso cronista decide passar um dia com os trabalhadores da estiva. Teria sido alertado por um delegado de polícia que se tratava de "criaturas ferozes". Ele mesmo descreve a primeira visão que teve dos trabalhadores em sua aproximação, num registro próximo ao do delegado. Os vira chegar "naquela confusão" e "a balançar o corpo".

Posso ir com vocês para ver?

Ele estendeu também a mão, mão degenerada pelo trabalho, com as falanges recurvas e a palma calosa e partida.

Por que não? Vai ver apenas o trabalho - fez com amarga voz.

(...)

Quem é aquele?

É o José. É chateiro-vigia. Passou todo dia ali para guardar a mercadoria dos patrões. Os ladrões são muitos. Então, fica um responsável por tudo, toda a noite, sem dormir, e ganha seis mil réis. Às vezes, os ladrões atacam os vigias acordados e o homem, só, tem que se defender a revólver (ANTELO, 1997, p. 258).

Novamente registra-se a marca do trabalho sobre o corpo dos trabalhadores e sua amarga percepção do peso de seu trabalho e da exploração. Ao mesmo tempo indica possuírem a 
consciência de que a exploração tinha uma fonte - o interesse do patrão, pelo qual José, chateirovigia, se arriscava sem ser devidamente recompensado com um salário adequado. Passava a noite sem dormir para ganhar seis mil réis. Mas ainda poderia ser pior. Havia os que transportavam sacos de sessenta quilos pelo que recebiam sessenta réis. "Alguns pagam menos: dão só trinta réis..." (ANTELO, 1997, p. 260).

Logo que o saveiro atracou eles pularam pelas escadas, rápidos; oito homens desapareceram na face aberta do porão, despiram-se, enquanto os outros rodeavam o guincho e as correntes de ferro começavam a ir e vir do porão para o saveiro, do saveiro para o porão carregadas de sacas de café. Era regular, matemático, a oscilação de um lento e formidável relógio.

Aqueles seres ligavam-se aos guinchos; eram parte da máquina; agiam inconscientemente. Quinze minutos depois de iniciado o trabalho, suavam arrancando as camisas. Só os negros trabalhavam de tamanco. E não falavam, não tinham palavras inúteis (ANTELO, 1997, p. 261).

Em meio ao mais intenso trabalho braçal a crônica nos permite observar as habilidades do ofício, porém, considerado pelo autor como ação mecânica e inconsciente de homens que "ligavamse aos guinchos". Era preciso sincronizar os movimentos e não se perder em "palavras inúteis".

Decerto pela minha face eles compreenderam que eu os deplorava. Vagamente, o primeiro falou; outro disse-me qualquer coisa e eu ouvi as ideias daqueles corpos que o trabalho rebenta. A principal preocupação desses entes são as firmas de estivadores. Eles as têm de cor, citam de seguida, sem errar uma: Carlos Wallace, Melo e François, Bernardino Correia Albino, Empresa Estivadora, Picasso e C, Romão Conde e C., Wilson, Sons, José Viegas Vaz, Lloyd Brasileiro, Capton Jones. Em cada uma dessas casas o terno varia de número e até de vencimentos, como por exemplo, o Lloyd, que paga sempre menos que qualquer outra empresa.

Os homens com quem falava tem uma força de vontade incrível. Fizeram com o próprio esforço uma classe, impuseram-se. Há doze anos não havia malandro que, pegado na Gamboa, não se desse logo como trabalhador de estiva. Nesse tempo não havia a associação, não havia o sentimento de classe e os pobres estrangeiros pegados na Marítima trabalhavam por três mil réis dez horas de sol a sol. Os operários reuniram-se. Depois da revolta começou a se fazer sentir o elemento brasileiro, e, desde então, foi uma longa e pertinaz conquista. Um homem preso que se diga da estiva, é, horas depois, confrontado com um sócio da União, tem que apresentar seu recibo do mês. Hoje estão todos ligados exercendo uma mútua polícia para a moralização da classe. A União dos Operários Estivadores consegue com uns estatutos que a defendem habilmente o seu nobre fim. Os defeitos da raça, as disputas, as rusgas são consideradas penas; a extinção dos tais pequenos roubos, que antigamente eram comuns, merecem o cuidado extremo da União, e todos os sócios, tendo como diretores Bento José Machado, Antonio da Cruz, Santos Valença, Mateus do Nascimento, Jerônimo Duval, Miguel Rosso e Ricardo Silva, esforçam-se, estudam sacrificam-se pelo bem geral.

Que querem eles? Apenas ser considerados homens dignificados pelo esforço e a diminuição das horas de trabalho, para descansar e para viver. 
Um deles, magro, de barba inculta, partindo um pão empapado de suor que lhe gotejava da fronte, falou-me num grito de franqueza:

O problema social não tem razão de ser aqui? Os senhores não sabem que esse país é rico, mas que se morre de fome? É mais fácil estoirar um trabalhador que um larápio? O capital está nas mãos de um grupo restrito e há gente demais absolutamente sem trabalho. Não acredite que nos baste os discursos de alguns senhores que querem ser deputados. Vemos claro e, desde que se começa a ver claro, o problema surge complexo e terrível. A greve, o senhor acha que não fazemos bem na greve? Eram nove horas de trabalho. De toda parte do mundo os embarcadiços diziam que o trabalho da estiva era só de sete!

O primeiro contato com os estivadores, observação de seu trabalho, teria provocado um sentimento de deploração em João do Rio, sentimento bastante comum para um intelectual em relação aos trabalhadores, principalmente os homens da estiva, executores de trabalho pesado, em sua maior parte negros. Mas, ao que parece, os preconceitos do jornalista vão se dirimindo a medida que os trabalhadores começam a falar-lhe, expressando sua ideias. Ideias "de corpos que o trabalho rebentava". Mostram, então, pleno conhecimento sobre as firmas contratantes de estivadores: quais eram, quanto pagavam. Contam a história da formação da sua classe pelo empenho de sua força de vontade.

Associação, sentimento de classe, reunião dos operários, revolta e conquista são palavras utilizadas. Os estivadores compreendem quem é seu interlocutor e aproveitam para fazer denúncias de suas condições de vida e trabalho e enaltecer a União da qual se procura passar uma imagem de organização interna sólida, de educadora dos vícios dos trabalhadores, além de sua protetora. Estratégia muito utilizada por associações operárias num momento em que viam necessário lutar contra o estigma do trabalhador numa sociedade marcada pelo escravismo e pelo elitismo.

Não há porque duvidar da versão tomando-a como pura propaganda quando nos deparamos com a história do associativismo de trabalhadores entre a segunda metade do século XIX e primeiras décadas do XX. Houve, sem dúvida, amplo esforço de auto organização e auto formação como se pode perceber na característica da diretoria dos estivadores ressaltada por aqueles homens e registradas pelo jornalista. Seus líderes "esforçam-se, estudam e sacrificam-se pelo bem geral”.

Por fim, não deixa de impressionar a consciência social e compreensão política demonstrada por um daqueles sujeitos representados como rudes e alienados. Em sua indignação, um deles localiza a acumulação do capital e os discursos amortecedores e demagógicos da classe política como dois grandes problemas a serem enfrentados. Demonstra, ainda, as trocas de informações entre "embarcadiços de toda parte do mundo" interpretadas e aproveitadas nas demandas e movimentos políticos da classe no Rio de Janeiro.

Aqueles homens que "pareciam parte dos guinchos" ou, confundiam-se com os sacos 
carregados e que de início foram deplorados pelo observador, agora o surpreendem, pois segundo aquele estivador, homem magro, barba inculta, que partia o pão gotejado pelo suor: "Vemos claro e, desde que se começa a ver claro, o problema surge complexo e terrível”.

A consciência que tem por matéria as relações de trabalho também é expressa no que diz respeito à cultura popular associada ao pertencimento étnico racial. Tal elaboração é dada a ver na crônica sobre Os presepes ${ }^{16}$.

Os presepes são uma criação popular. Antes dos artistas de Paris e Viena, que expõe nos salões do Campo de Marte e no Kunstlerhaus, o povo criou nos presepes o anacronismo religioso, o anacronismo que, segundo $\mathrm{La}$ Sizeranne é a fé... (ANTELO, 1997, p. 198).

$\mathrm{Na}$ criação e festejo do reisado ${ }^{17}$ percebemos uma forte marca da produção intelectual e artística no universo popular: a coletividade. Na mesma crônica vemos ainda que a ação coletiva era organizada. Os presepes possuíam suas diretorias compostas por vários membros, presidente e vice presidente. O presepe da Rua Frei Caneca, o Centro Pastoril, chegava mesmo a ter uma "sala e a primeira alcova da casa da Rua Frei Caneca [alugada] apenas para que a festa redobrasse de brilho" (ANTELO, 1997, p. 199 e 200).

Em contato com a manifestação, o cronista se esforça para compreender o porque fazem os presepes e a simbologia ali contida. Desenrolam-se, nesse sentido, suas conversas com Dudu, membro da festa na praia Formosa.

O mais interessante, porém, fui encontrar na praia Formosa, centro de um cordão carnavalesco de negros baianos. Essas criaturas dão-me a honra da sua amizade. O presepe está armado no quarto da sala de visitas. É inaudito, todo verde com lantejoulas de prata.

O céu, pintado por um artista espontâneo, tem entre nuvens, o sol com uma cara raspada de americano truster (empresário), a lua maior que o sol, com a imagem da Virgem mãe.

(...)

Aproveito a consideração do Dudu para compreender o presepe:

Por que diabo põe vocês o retrato da Imperatriz ali?

Imperatriz era a mãe dos brasileiros e está no céu.

Mas Napoleão, homem, Napoleão?

Então, gente, ele não foi rei do mundo? Tudo está ali pra honrar o menino Deus.

A bailarina também?

A bailarina é enfeite.

O que podia parecer confuso para um espectador de outro ambiente cultural, possuía sentido

16 Presepes, ou presépios, são nichos ou construções que se armam nas festas de Natal e Reis, representando, geralmente, o estábulo onde teria nascido Jesus Cristo.

17 Reisado é uma dança popular profano religiosa, de origem portuguesa, com que se festeja a véspera do Dia de Reis, dia em que o menino Jesus recebera a visita dos Reis Magos. 
próprio para quem estava imerso no ambiente dos presepes, vendo-nos serem construídos ou mesmo participando de sua construção ano a ano. Para eles, a lógica de tantos personagens anacronicamente misturados, de Napoleão à Imperatriz, estava bem clara. As figuras mais poderosas da história estariam ali, independente de nossa percepção mais linear do tempo, para louvar o verdadeiro rei - Jesus - Deus de quem todo aquele povo por ser filho seria herdeiro. Estava subvertida a ordem dos poderes terrenos. Ao explicar os significados, o Dudu ainda alerta, com jeito aparentemente irreverente, que nem tudo tinha que ter um significado estabelecido: a bailarina era só enfeite.

Mas João do Rio continuava curioso e o mesmo Dudu seguia sanando suas dúvidas.

Mas por que - continuo eu curioso - põe vocês junto do rei Baltasar aquele boneco de cacete?

Aquele é o rei da capoeiragem. Está perto do rei Baltasar porque deve estar. Rei preto também viu a estrela. Deus não esqueceu a gente. Ora não sei se V. S. conhece que Baltasar é pai da raça preta. Os negros da Angola quando vieram da Bahia trouxeram uma dança chamada cungu, em que se ensinava a brigar. Cungu com tempo virou mandinga e São Bento.

Mas que tem tudo isso?...

Isso, gente, são nomes antigos da capoeiragem. Jogar capoeira é o mesmo que jogar mandinga.

Então os capoeiras estão nos presepes para acabar com as presepadas...

Sim senhor. Capoeiragem é uma arte, cada movimento tem um nome. É mesmo como sorte de jogo (ANTELO, 1997, p. 207 e 208).

Trazendo sempre as figuras da história universal para seu universo de significados, o povo da praia Formosa realizava um exercício de afirmação racial ao inserir no presepe um "Rei da capoeiragem" ao lado do Rei Baltasar, este também negro. Era ali que devia estar numa possível lógica de agregação da raça. É por meio de Baltasar que Dudu, em notório tom de crítica ao preconceito e posição subalternizada dos negros no Brasil, mostra o quanto Deus não se esquecera de sua raça. E tampouco aquele povo esquecera-se de sua história, contam naquela miniatura sobre a vinda da capoeira de Angola, uma arte que define como complexa, com seus diferentes nomes para diversos movimentos.

Consciência, criatividade, "jogo de cintura" que valia os sujeitos das classes populares na elaboração de suas táticas de sobrevivência. Voltando aos tatuadores, observamos que para desenvolverem seu ofício, montaram toda uma "indústria" da "marcação".

A outra camada é a mais numerosa, é toda classe baixa do Rio - os vendedores ambulantes, os operários, os soldados, os criminosos, os rufiões, as meretrizes. Para marcar tanta gente a tatuagem tornou-se uma indústria com chefes, subchefes e praticantes. (...)

Os marcadores têm uma tabela especial, o preço fixo do trabalho. As cinco chagas custam $1 \$ 000$, uma rosa $2 \$ 000$, o signo de Salomão, o mais comum 
e o menos compreendido porque nem um só dos que interroguei o soube explicar, 3\$000, as armas da monarquia e da república $6 \$ 000$ a $8 \$ 000$, e há Cristos para todos os preços.

Os tatuadores têm várias maneiras de tatuar: por picadas, por incisão, por queimadura subepidérmica. As conhecidas entre nós são as incisivas nos negros que trouxeram a tradição da África e, principalmente, por picadas que se fazem por três agulhas amarradas e embebidas em graxa, tinta, anil ou fuligem, pólvora acompanhando o desenho prévio. O marcador trabalha como as senhoras bordam (ANTELO, 1997, p. 105, 106 e 107).

Contrariando outra concepção corrente sobre as classes populares como desorganizadas e incapazes de produzir com autonomia, vemos aí uma atividade econômica toda desenvolvida a partir desses sujeitos que estipulavam o valor de seu serviço em tabela e organizavam o mercado. Possuíam conhecimentos próprios ao ofício que se aproximavam tanto de um saber cirúrgico propagado, inclusive, por negros vindos da África, como da arte das bordadeiras.

Mas é o caso do marinheiro Joaquim o mais exemplar no que diz respeito a capacidade de usar as brechas do cotidiano como forma de preservar-se em um "jogo jogado no campo do adversário". Frente aos guardiães da armada ele faz uso de sua tatuagem para desferir "golpes" (CERTEAU, 1985).

O marinheiro Joaquim tem um Senhor crucificado no peito e uma cruz negra nas costas. Mandou fazer esses símbolos por esperteza. Quando sofre castigos os guardiões sentem-se apavorados e sem coragem de sová-lo.

Parece que estão dando em Jesus! (ANTELO, 1997, p.109)

Para observar Joaquim como ativo em uma relação de poder, certamente desigual, mas na qual ele não era mera vítima inerte, seria preciso alçá-lo a condição de sujeito pensante, capaz de atos de esperteza. Entre as percepções hegemônicas em seu tempo como o racismo científico ${ }^{18}$ e o lombrosianismo ${ }^{19}$ e seu pertencimento social por um lado e sua sensibilidade aliada às contradições de homem marginalizado pela opção sexual e aparência física por outro, flagramos um arroubo quase certeauniano em João do Rio ao registrar a tática, pura esperteza no uso da tatuagem pelo marinheiro Joaquim. O Senhor crucificado e a santa cruz literalmente livram-no de certo mal - as pancadas dos guardiões. Nesse mesmo registro o fechamento da crônica sobre os tatuadores revela também um atípico espírito antropológico:

A pobre Anita mostra no calcanhar por extenso o nome do pai dos seus filhos e traz em cada seio a inicial dos dois pequenos como numa eterna oferenda - a sua única oferenda de mãe aos desgraçados perdidos...

Num meio de tão fraca ilusão, onde as miçangas substituem os pendentifs

18 Concepção veiculada em meios científicos oitocentistas sobre características inerentes às raças. Um exemplo clássico é o esquema racial do Conde de Gobineau que definia hierarquicamente as características, capacidades intelectuais e propensões morais das três raças: branca, amarela e negra.

19 Concepção fundamentada em biótipo formado por caracteres supostamente inatos de criminosos. O termo advém de Cesare Lombroso, criminologista italiano (1835-1909) que iniciou os estudos de antropologia criminal. 
d'arte e a vida ruge entre o desejo e o crime, depois de muito ver os pobres entes marcados como uma cavalhada - a cavalhada da luxúria e do assassínio - começa a gente a sentir uma concentrada emoção e a imaginar com inveja o prazer humano, o prazer carnal, que eles terão ao sentir um nome e uma figura debaixo da pele, inalteráveis e para todo o sempre.

Aquele pequeno impressionou-me de novo na sua profissão estranha. Indaguei:

Quanto fizeste hoje?

Hoje fiz doze mil réis.

E eu compreendi que, afinal, tatuador deve ser uma profissão muito mais interessante que a de amanuense de secretaria...(ANTELO,1997, p. 112).

Ao relativizar o sentido das tatuagens como "oferenda de uma mãe a seu filho", ou emoção e prazer, o cronista chegava a invejar os que se marcavam de tal forma, ainda que estes fossem "pobres marcados com a cavalhada da luxúria e do assassínio". Nota-se que a esta sensibilidade foi desenvolvida ao longo de certo tempo de contato humano "depois de muito ver os pobres entes". A partir daí repensa a figura do petiz citado nas primeiras linhas, estabelecendo uma comparação favorável ao ofício do tatuador em relação à tediosa "burocracia de um amanuense de secretaria".

Por fim, detenhamo-nos nas histórias do Madruga e do Arcanjo, trazidas à luz a partir dessa mesma perspectiva atenta às identidades próprias dos homens e mulheres das classes populares. Gente que o autor individualizava quando a maior parte das abordagens contemporâneas tendia a homogeneizar como "massa" em crescimento na fermentação do urbano. O Madruga, chefe dos tatuadores, exemplo de versatilidade, circulava pelas ruas da Conceição e de São Jorge e eventualmente pela casa de detenção, vivia entre amantes, modinhas satíricas e a poesia.

\section{É dele este primor que julga verso: \\ Venha quanto antes D. Elisa \\ Enquanto o Chico Passos não atiça \\ Fogo na cidade}

Homem tão interessante, guarda no corpo a síntese dos emblemas das marcações - um Cristo no peito, uma cobra na perna, o signo de Salomão, as cinco chagas, a sereia e, no braço esquerdo, o campo das próprias conquistas (ANTELO, 1997, p. 106). Na figura do Madruga, vemos a associação da arte do desenho no corpo à outras como a composição de modinhas satíricas e de poesia. Esse homem, tão avesso à disciplina que a escola era encarregada de transmitir, estava inserido no universo da escrita, e mais, da escrita autônoma, criativa. Nos versos selecionados por João do Rio podemos ver a capacidade de crítica política, à medida que alerta para o perigo de Chico Passos (o prefeito do Distrito Federal, Francisco Pereira Passos) atiçar fogo na cidade, mais um provável meio de concretizar a turbulenta (truculenta) reforma urbana.

Ao caracterizar o Madruga como "interessante" o intelectual destaca aquele homem de segmento social. Movimento que, hoje, à luz de pensamentos como os de Ginzburg, Certeau e 
Thompson, podemos complexificar lembrando que, mesmo sendo o poeta e tatuador um sujeito peculiar, sua arte só tinha sentido porque compreendida e apreciada por seu público, gente que o circundava $^{20}$.

É com um dos personagens que atraiu a atenção de nosso cronista que encerro esta análise. Trata-se do Arcanjo, italiano, analfabeto, vendedor de livros e jornais na esquina do Teatro São Pedro, "gordo, desconfiado e pançudo" (ANTELO, 1997, p.136). Analfabeto vendendo livros! O comerciante também nos desperta curiosidade séculos depois. Um vendedor de livros que não lê... A figura de Arcanjo pode nos suscitar muitos questionamentos e nos levar a uma complexificação do sentido do termo "analfabeto". Como poderia ele realizar seu trabalho sem tal habilidade? É muito provável que fosse bom nos cálculos, especialmente nos “cálculos mentais" como é comum entre vendedores... E quanto a ler, certamente os livros representavam para ele mais do que a decifração do código escrito, o que lhe permitia seu manuseio. Havia aspectos da materialidade desse objeto as cores, o formato das letras, o volume da edição, as figuras e outros sinais a possibilitarem-lhe, talvez, a fluência em uma leitura que não era a "da escola", aquela que passou a certificar "alfabetização", mas a "encantadora leitura das ruas".

\section{2- A política das classes populares}

Como podemos perceber a educação popular não se restringe a escola. Da mesma forma podemos dizer que a política feita pelas classes populares não se restringe ao parlamento e ao voto. A ideia do povo apolítico, bem como do povo não educado, precisa ser relativizada por uma ótica que revele outras formas de educação e inserção política. Talvez ainda esperemos encontrar uma unidade no sentido de "povo" que nos dificulte perceber as ações políticas dos diferentes grupos mais ou menos organizados que o constituem. Outro fator que pode comprometer nossa compreensão da realidade é a concepção de política exclusivamente na esfera do Estado, ou com vistas a ele, ação resumida essencialmente no voto. Sabemos que esta não é a única forma de participação nas relações de poder. É o que José Murilo de Carvalho demonstra para o período de passagem da monarquia para a República em fins do século XIX.

O autor discute em seu clássico Os Bestializados, a comunidade política do Brasil, a forma

20 Este conjunto seria classificado mais a frente como "atrasados morais" entre os quais assimila para em seguida distinguir "a camada que trabalha braçalmente" e "o oceano de malandragem e da prostituição". Como já lembrado, João do Rio seguia, como homem de seu tempo e de sua classe, os referenciais de Lombroso, muito em voga ao se tratar do povo das ruas e criminalidade, João do Rio realiza a habitual separação entre trabalhadores braçais e o oceano da malandragem e do vício, identificando todos, entretanto, como "atrasados morais", "pertencentes a meio mais primitivo". Não deixava de ser tênue a linha que separava, ao olhar das autoridades e da intelectualidade urbana, os homens e mulheres trabalhadores pertencentes às classes populares dos malandros, vagabundos e criminosos em geral, as chamadas "classes perigosas". 
como nos governamos, ou somos governados e o faz pensando a cidadania, a relação entre Estado e sociedade. Toma um momento crucial na vida política do país: a passagem do Império para a República inspirado nas observações de Aristides Lobo - "o povo assistiu à proclamação da República bestializado"; e do francês Louis Couty, residente há muito no Brasil - "no Brasil não há povo". Procurando escapar de uma visão maniqueista sobre a relação Estado e sociedade o autor esclarece que, na prática, o maniqueísmo acaba por revelar uma atitude paternalista em relação ao povo ao considerá-lo vítima impotente diante das maquinações do poder do Estado, ou dos grupos dominantes, e dessa forma bestializa o povo. "Parece-nos, ao contrário, que somente em casos muito excepcionais e passageiros de sistemas baseados totalmente na repressão, é mais fecundo ver as relações entre cidadãos e Estado como uma via de mão dupla, embora não necessariamente equilibrada. Todo sistema de dominação para sobreviver terá de desenvolver uma base qualquer de legitimidade, ainda que seja a apatia dos cidadãos" (CARVALHO, 2006, p. 11).

Para Carvalho (2006, p. 38) havia, no Rio de Janeiro, um vasto mundo de participação popular que passava ao largo do mundo oficial da política.

A cidade não era uma comunidade no sentido político, não havia o sentimento de pertencer a uma entidade coletiva. A participação que existia era de natureza antes religiosa e social e era fragmentada. Podia ser encontrada nas grandes festas populares da Glória e da Penha, e no entrudo, concretizava-se em pequenas comunidade étnicas, locais ou mesmo habitacionais, um pouco mais tarde apareceria nas associações operárias anarquistas. Era a colônia portuguesa, a inglesa, eram as colônias compostas por imigrantes de vários estados, era a Pequena África da Saúde formada por negros da Bahia, onde sob a maternal proteção da Tia Ciata, se gestava o samba carioca e o moderno carnaval. Eram as estalagens cuja população podia chegar a mais de mil pessoas. O cortiço de Botafogo descrito por Aluísio de Azevedo, possuía no final mais de 400 casas e constituía uma pequena república com vida própria, leis próprias, detentora de inabalável lealdade de seus cidadãos, apesar do autoritarismo do proprietário. Aluísio, aliás, fala expressamente na 'República do Cortiço'. Ali se trabalhava, se divertia, se fornicava, se festejava e principalmente se falava da vida alheia e se brigava. (...) Frente à polícia, dono e moradores se uniam, pois estava em jogo a honra e soberania da pequena república. Cortiço em que entrava polícia era cortiço desmoralizado. É profundamente irônico e significativo que a república popular do cortiço se julgasse violada, derrotada, quando lá entrava o representante da República oficial. No romance, o cortiço consegue evitar a entrada da polícia, mas na vida real, dois anos após a publicação do livro, o cortiço Cabeça de Porco seria destruído em autêntica operação militar pelo republicano histórico Barata Ribeiro. O governo da república destruía as repúblicas sem integrá-las numa república maior que abrangesse todos os cidadãos da cidade (CARVALHO, 2006, p. 39).

A república, como antes o império, não integrava socialmente as classes populares e os excluía politicamente. A exclusão dos analfabetos pela constituição republicana teria sido 
particularmente discriminatória. Apesar da reforma eleitoral que lhes impedia o voto datar de 1881, o autor constata que a república furtou-se, em seu texto constitucional, do provimento de educação para o povo. "Exigia-se para a cidadania política uma qualificação que só o direito social da educação poderia fornecer e, simultaneamente, desconhecia-se esse direito. Era uma ordem liberal, mas profundamente antidemocrática e resistente a esforços de democratização" (CARVALHO, 2006, p. 46).

Segundo Chalhoub, o problema da reforma eleitoral de 1881 era relativo a definição de cidadania num contexto de crise do regime escravista. "Na segunda metade do século XIX, o problema era definir os direitos políticos dos descendentes de escravos. Após a lei de 1871 [Lei do Ventre Livre], havia o temor de que os filhos de escravos nascidos livres viessem a adquiri cidadania plena ao atingir a maioridade, tornando-se agentes formais do mundo político" (CHALHOUB, 2003, p. 211). A solução a brasileira desse problema, exigência da capacidade de ler e escrever para a qualificação de eleitores (Lei de Reforma Eleitoral de 1881) alijou milhares e milhares de descendentes de escravos da política formal na década seguinte.

Vemos, então, que desde muito cedo, na história da formação de nossa nação, foi confundido instrução e capacidade de exercício da cidadania política. Não se trata de mero equívoco em um debate que ecoa até hoje. Nem tampouco será a escola o único espaço de marginalização dos saberes e culturas populares. O presente capítulo pretende defender a ideia de que a Reforma Eleitoral, lei no 8213 de 9 de janeiro de 1881, também conhecida como Lei Saraiva, em certo sentido, representou uma forma de institucionalização da separação entre a instrução e a experiência.

Não tomaremos a reforma como um tema específico a ser aprofundado, mas sim como evento relevante no âmbito da relação classes populares, educação e política, no período aqui analisado. Ela nos ajuda a refletir sobre a construção do "mito da alfabetização" (GRAFF, 1995), do preconceito contra o analfabeto (GALVÃO \& DI PIERRO, 2007), sobre o processo de separação entre saberes populares e saberes oficiais, escola e vida e ainda compreender a própria luta popular por escolarização, ensejando outra reflexão sobre a resistência dos saberes de experiência e sobre o próprio educar-se das classes populares.

É importante ter em mente como funcionava, em linhas gerais, o sistema eleitoral, antes da reforma. No império votava-se para Juiz de Paz e vereadores, no âmbito local. No âmbito provincial e nacional votava-se para a assembleia provincial, a câmara dos deputados e o senado. As eleições do nível provincial e nacional eram indiretas em dois níveis. Todas as eleições passaram a ser diretas a partir da reforma de 1881. Podiam votar homens com mais de 25 anos, 21 se casados, ou se oficiais militares. Se clérigos ou bacharéis podiam votar com qualquer idade. Mulheres e 
escravos não votavam, libertos votavam apenas nas eleições de primeiro grau. Havia exigência de renda anual para votar: 100 mil réis por ano para votante e 200 mil réis por ano para eleitor. A partir de 1846 os valores são atualizados para 200 mil réis e 400 mil réis respectivamente.

A constituição de 1824 não condicionou o direito de voto à alfabetização, mas entre 1824 e 1842, a legislação exigia que a cédula fosse assinada, o que limitou na prática o voto dos analfabetos. Entre 1842 e 1881, os analfabetos puderam ser votantes e eleitores. Por exemplo, um levantamento da lista de votantes de 1876 , feito em oito paróquias da cidade do Rio de Janeiro, revela um contingente significativo de votantes que não sabiam ler e escrever: um em cada quatro. Nas paróquias rurais como Guaratiba e Jacarepaguá os analfabetos ultrapassavam os 50\% (NICOLAU, 2002, p. 11).

Mudanças significativas vieram com o Decreto $\mathrm{N}^{\text {o }} 3029$ de 9 de janeiro de 1881 que reformou a legislação eleitoral. Ele dispunha, em seu primeiro artigo, que as eleições para senadores, deputados membros da assembleia geral, bem como os membros das assembleias provinciais e quaisquer autoridades eletivas seriam, desde então, diretas. Os eleitores seriam:

(...) todo cidadão brasileiro, nos termos dos arts. $6^{\circ}, 91$ e 92 da Constituição do Império, que tiver renda liquida anual não inferior a $200 \$$ por bens de raiz, indústria, comércio ou emprego. (...) Os habilitados com diplomas científicos ou literários de qualquer faculdade, academia, escola ou instituto nacional ou estrangeiro, legalmente reconhecidos. (...) Os que desde mais de um ano antes do alistamento dirigirem casas de educação ou ensino, frequentadas por 20 ou mais alunos, ou leccionarem nas mesmas casas. (...) Os juízes de paz e os vereadores efetivos do quatriênio de 1877-1881 e do seguinte, e os cidadãos qualificados jurados na revisão feita no ano de $1879^{21}$.

O Decreto n 8213, de 13 de Agosto de 1881 que regulava a execução da Lei n. 3029 de 9 de Janeiro do mesmo ano adenda aos acima citados, como eleitores que não precisavam comprovar renda, "Os diretores, lentes e professores das faculdades, academias e escolas de instrução superior, os inspetores gerais ou diretores da instrução pública na corte e nas províncias, os diretores ou reitores de institutos, colégios ou outros estabelecimentos públicos de instrução e os respectivos professores, os professores públicos de instrução primária por título de nomeação efetiva ou vitalícia". Podemos observar que a instrução se torna critério de restrição do voto por um lado, enquanto por outro se torna fator de facilitação.

Mas será o artigo oitavo da reforma que vedará o voto aos analfabetos que pleiteassem o alistamento pela primeira $v^{22}$. Ao legislar sobre a revisão do alistamento geral de eleitores em

21 Decreto $\mathrm{n}^{\mathrm{o}} 3029$ de 9 de janeiro de 1881. Disponível em: http://www.tse.jus.br/hotSites/glossarioeleitoral/termos/anexos/textos/html_leis/lei_saraiva.htm Acesso em 20 de janeiro de 2012.

22 A reforma imperial que vedou o voto ao analfabeto teve continuidade após a implantação do regime republicano. "Uma das primeiras medidas do governo republicano foi abolir a exigência de renda para ser eleitor ou candidato. Por outro lado, em um artigo singelo, os analfabetos foram proibidos de votar, restrição que só seria suspensa cem 
todo o império, determinava que deveriam ser eliminados dele os eleitores “(...) que tiverem falecido ou mudado de domicílio para fora da comarca, os falidos não reabilitados, os que estiverem interditos da administração de seus bens, e os que, nos termos dos arts. $7^{\circ}$ e $8^{\circ}$ da Constituição, houverem perdido os direitos de cidadão brasileiro ou não estiverem no gozo de seus direitos políticos". Entretanto, só poderiam ser inscritos, a partir daquele momento, aqueles que provassem sua condição de eleitor e que soubessem ler e escrever. A prova seria dada pela letra e assinatura do cidadão. Ou seja, o critério da leitura e da escrita passava a ser usado apenas para novos eleitores. Os analfabetos que já estivessem alistados desde processos passados, manteriam seus direitos políticos, tanto que os próprios títulos de eleitores designavam aqueles que sabiam e os que não sabiam ler e escrever. De onde podemos concluir que os homens ricos, desde antes eleitores, mesmo que analfabetos, não deixaram de ser. Logo, não houve alteração no status quo, porque seus descendentes já seriam enviados para a escola com todas as condições necessárias.

Podemos afirmar que a realidade do sistema eleitoral foi, desde o início, controlada por leis escritas - uma escrita organizadora vide os alistamentos, editais, etc. E uma escrita comprobatória, vide certidões e tantas outras documentações/papéis. Porém, até antes de 1881, esse tipo de codificação não impedia aqueles que não sabiam ler e escrever, preenchendo os critérios de renda e alguns outros, de participar do processo eleitoral. Por exemplo, os editais que convocavam o alistamento de eleitores eram afixados em espaço público. É muito provável que um leitor pudesse difundir em voz alta a mensagem ali contida. Além do que, homens eleitores analfabetos possuíam suas redes de relações que os auxiliaria com o manejo dos papéis. As interdições da lei de 1881 foram escolhas político ideológicas e não técnicas. A dificuldade da comprovação da condição de eleitor expressa nos inúmeros artigos sobre provas documentais foi outro fator de restrição do número de eleitores.

Segundo Nicolau (2002), vários estudos de caso feitos em determinadas cidades e províncias revelam que, até 1880 , entre $5 \%$ e $10 \%$ da população estava inscrita para votar. Após a entrada em vigência da Lei Saraiva, em 1881, houve uma notável redução do eleitorado.

Quando se compara o número de votantes do começo da década (1873) com o de eleitores após a promulgação da lei (1882), observa-se um declínio acentuado (87\%): o eleitorado inscrito passou de 1,1 milhão para $142 \mathrm{mil}$ eleitores. As causas foram, provavelmente, a introdução de critérios muito rigorosos para comprovação de renda, a exigência de se saber ler e escrever para inscrição de novos eleitores e o fim do alistamento automático (agora o eleitor deveria requisita a qualificação por sua iniciativa). Por outro lado, como se toma como base para comparação os antigos eleitores de segundo grau, observa-se que houve um crescimento de $614 \%$, passando de $20 \mathrm{mil}$

anos depois: "considerem-se eleitores, para as câmaras gerais, provinciais e municipais, todos os cidadãos brasileiros, no gozo de seus direitos civis e políticos, que souberem ler e escrever (decreto $\mathrm{n}^{\circ} 6$ de 19 de novembro de 1889)""' (NICOLAU, 2002, p. 26). 
para 140 mil...” (NICOLAU, 2002, p. 24).

A interdição de direitos políticos não estaria só na negação do voto. É o que mostra Chalhoub ao estudar os pareceres do Conselho de Estado para pedido de reconhecimento dos estatutos da Sociedade Beneficente da Nação Conga Amiga da Consciência. A interdição estaria também "[no] fato do governo imperial opor-se à organização de sociedades de trabalhadores negros alegando, entre outras coisas, que suas diretorias não sabiam ler e escrever" (CHALHOUB, 2003, p. 265).

Antes mesmo da difusão do termo "analfabeto", ler e escrever eram exigências para o reconhecimento de legitimidade política pelo Estado num momento em que "apenas 23,3\% dos homens e 13,43\% das mulheres sabiam ler e escrever, numa média de 18,56\% de alfabetizados, incluindo os escravos essa média final descia para 15,75\%" (CHALHOUB, 2003, p. 286). Porém, mais dos que os números em si, nos interessa a representação que se fazia deles. Observemos a análise de Chalhoub (2003) sobre crônica de Machado de Assis, em 1876, que trata da relação alfabetização e cidadania:

De qualquer modo, ao utilizar-se dos números com esse tipo de viés político, o Sr. Algarismo exprimia visão bastante comum à época, de que saber ler e escrever era requisito para as virtudes cívicas. Tal opinião constituía-se em 'verdade axiomática', adotada por todos os espíritos independentemente de filiação partidária, segundo Sérgio Buarque de Holanda. Tal situação contrastava com a vigente entre os constituintes de 1823 , que não cogitaram incluir restrições aos direitos políticos dos analfabetos num país em que tal condição abundava. $\mathrm{Na}$ década de 1870 generalizara-se o conceito de que a alfabetização dos cidadãos era essencial para moralizar a vida política do país.

Os ideais da reforma eleitoral serão motivadores do desenvolvimento de iniciativas educacionais para ensino de primeiras letras, principalmente a adultos analfabetos, como o expressivo exemplo dos cursos noturnos. Isso não seria suficiente, alegam os críticos da lei de 1881, entre eles Joaquim Nabuco, que em 27 de maio de 1879 pronuncia o esclarecedor discurso:

'Outro meio, senhores, que se empregou para responder a tudo que dissemos quanto aos analfabetos, consiste em representar-nos como amigos da ignorância. Nós somos apresentados como autores da propaganda sinistra do obscurantismo, como inimigos da escola, como adversários da iniciativa do honrado Sr. ministro do império, a quem devo dizer que prefiro que S. Ex. multiplique escolas no país a que as multiplique no papel, como inimigos da necessidade que tem todo homem de saber ler e escrever. (...) Mas o que não deveis fazer é criar categorias de analfabetos, classes sociais de analfabetos, mesmo porque quando fazeis isto, além de excluirdes das urnas cidadãos que não tem culpa de não saber ler e escrever, dai às mesas qualificadoras um pretexto a mais para afastar das urnas quem não for do seu partido' (Apud CHALHOUB, 2003, p. 286).

Corroborando a percepção de Nabuco e outros parlamentares contrários à lei de 1881, como 
José Bonifácio, Chalhoub conclui que "ninguém acreditaria que membros das supostas 'massas inconscientes' dos que não sabiam escrever seriam autores de qualificações fraudulentas de eleitores, atas falsas, apurações forjadas. Como poderiam, sendo analfabetos?". E ainda que "o governo continuaria a vencer as eleições porque permaneceria a seu dispor as armas habituais para fazê-lo: distribuição de empregos públicos, regalias em contratos, comissões rendosas, honrarias diversas" (CHALHOUB, 2003, p. 286).

A análise feita por Nabuco, Bonifácio e pela historiografia atual já aparecia entre redatores de periódicos operários, sujeitos que se auto classificavam também como parte dessa "classe operária". Estes sujeitos, excluídos do direito do voto por serem considerados "inconscientes", "ignorantes" e "incapazes" de realizar "tão importante escolha" demonstravam nas páginas de Gazeta Operária, perfeito conhecimento das razões da exclusão e um posicionamento crítico, refletido e redigido quanto a elas, apenas quatro dias depois ter sido decretada a lei.

Mas, qual, engano; o Sr. Saraiva é de um tino... a prova é que fez passar o artigo $8^{\circ}$ enquanto excluía a maior parte dos legítimos cidadãos que mais concorrem para o progresso e engrandecimento da pátria, pretextando a inconsciência com que exerciam o sacratíssimo direito de cidadãos. (...)

O proletariado, único mercadejador da consciência, na opinião de S. Ex. o Sr. conselheiro Saraiva, está para todo sempre condenado e despojado do supremo direito de cidadão!...(...)

Acabaram-se os capangas, os fósforos ${ }^{23}$ jamais terão extração e as baionetas do governo não farão correr mais o sangue do turbulento, inconsciente e miserável mercadejador do voto, o operário!...(...)

Concluiu, finalmente, V. Ex. a sentença que há muito sonhava para lavrar sobre as classes menos favorecidas e sobre o povo pobre - A Reforma Eleitoral!

De modo que só os Srs. proprietários e capitalistas são os considerados cidadãos. E podem gozar dos direitos que lhes são facultados pela reforma eleitoral! (...)

Pois bem, Sr. conselheiro. V. Ex. que passa em toda sua carruagem pelas ruas da cidade, lançando olhares para as multidões, encontrará muitos operários pobres, mas honrados, porque tem a consciência sã e o caráter nobre, não estão ainda corrompidos pelo vício torpe da bajulação como aqueles que descem ao balcão da venalidade, olvidando os mais sacrossantos princípios da sociedade e da natureza, alugando a consciência podre para empolgar as altas posições sociais.

É necessário, pois, que V. Ex. e todos quantos se acham colocados nas altas posições sociais, compreendam que o operário é um homem que tem um cérebro que pensa e não uma máquina...

O operário de 1881 não é o mesmo operário de 1850 nem de 1860 que só cuidava em trabalhar, comer e dormir.

O operário de 1881 trabalha, come, lê folhas diárias, vai ao teatro, estuda nas aulas noturnas, desenvolve seu talento em reuniões literárias, nas imprensas e nas tribunas populares, inocula no coração os verdadeiros germens das doutrinas sociais e não deixa passar impunemente as afrontas que lhe são feitas, aceita

23 Segundo Nicolau (2002, p. 12) “O invisível, o fósforo, representa um papel notável nas nossas eleições, e mais ainda nas grandes cidades do que nas freguesias rurais”. O fósforo era aquele sujeito que votava três, quatro, cinco e mais vezes por si e pelos ausentes, principalmente aqueles já falecidos, em várias freguesias quando eram próximas. 
sempre o reto, quando lhe é atirado em face, porque conhece o que é reação ${ }^{24}$.

O trecho acima, retirado das edições de 12 e 22 de janeiro de 1881 da Gazeta Operária pode ser decomposto segundo seus argumentos. De início, analisa que a razão de inconsciência popular dada para instituição dos critérios de renda e alfabetização é apenas um pretexto. Em seguida, deixa claro que a parcela da sociedade a ser excluída em decorrência da lei será "o proletariado", "o operário", “as classes menos favorecidas", “o povo pobre”. Nesse sentido expõe a luta de classes subjacente à reforma quando afirma que só os senhores proprietários capitalistas são considerados cidadãos.

Por fim, resume o que tenho gasto páginas para defender no presente trabalho, o fato de que “o operário é um homem que tem um cérebro que pensa". Mostra-se assim bastante consciente acerca das representações sociais sobre o operário naquele momento, quando se estabelecia a identificação entre títulos acadêmicos - escolares e capacidade intelectual, entre instrução e capacidade política. Momento em que se aprofundava a separação entre saber de experiência e saber oficial, escolarizado. Longe de conforma-se, o redator da Gazeta contra argumentava esta nova verdade sem negar, no entanto, o valor das novas formas de acesso ao conhecimento. Pelo contrário, afirma que “o operário de 1881” já estava em sua busca ao ler folhas diárias, ir ao teatro, estudar nas aulas noturnas, participar de clubes literários, imprensas e tribunas populares. A educação aparece, assim, para as classes trabalhadoras, como forma de participar socialmente, ferramenta de luta simbólica neste embate com o Estado, reconhecido no artigo de Gazeta Operária, como defensor dos direitos dos "Srs. proprietários e capitalistas".

Os operários leitores, mas também os que escutavam ler, os que ouviam as notícias correntes de boca em boca, tiveram acesso aos debates sobre a reforma e, provavelmente, mesmo sem saberem ler e escrever, desenvolveram uma opinião política sobre ela. Contaram eles com alguns jornais da imprensa operária atentos às consequências e motivações da nova lei eleitoral. $\mathrm{Na}$ pesquisa realizada sobre periódicos direcionados às classes trabalhadoras, que serão abordados no terceiro capítulo desta tese, foram encontrados artigos em dois diferentes jornais, no ano de 1881, que discutiam a reforma. Em 12 de janeiro e em 22 de janeiro, a já referida Gazeta Operária: órgão dedicado especialmente aos interesses dos artistas e operários, publica em "Colaboração", o texto "A Reforma Eleitoral”, e na seção "A Pedidos" traz "O Critério" com subtítulo "A reforma eleitoral".

A Gazeta, cujos números disponíveis na Biblioteca Nacional vão do primeiro ao quarto, era editada na corte. Ela não informa sobre seu raio de circulação, mas é provável que chegasse, ao menos, a Niterói, além da corte, e talvez algumas outras cidades da província do Rio de Janeiro. Seu

24 Composição de artigos de Gazeta Operária, em 12 e 22 de janeiro de 1881. 
primeiro número é de 8 de janeiro de 1881 e pretendia cobrar baixos valores aos assinantes, ainda que fossem “(...) bem ao nosso pesar [considerados altos mesmo assim] porque as publicações impressas no Brasil são caríssimas, mormente quando se pretende obter um bom serviço" 25 . Desde seu editorial, o jornal se afirmava como "parcela desse grande todo, que representamos a maioria o povo". Parte do povo que, organizada e portadora da habilidade da escrita, pretendia ser "manifestação pujante do movimento reacionário de uma classe inteira que se sente proscrita do grêmio social pela arbitrariedade dos homens do poder" 26 .

Lançado um dia antes da publicação do decreto 3029 de 9 de janeiro de 1881, que reformava a legislação eleitoral, as palavras do redator já pareciam fazer referência às restrições do voto popular pelo aumento da renda exigida e pelo critério da alfabetização. Na seção "Corre por aí" desta primeira edição, podemos encontrar críticas irônicas à reforma ${ }^{27}$. "Corre por aí... Que a reforma anti operária, volta à câmara de onde saiu como os corpos ao nada de onde vem a luz... Que assim como há senadores que não falam há também camaristas que assinam de cruz... Que a reforma alargaria os horizontes do país com consciência do voto”. Como cobrar dos eleitores alfabetização, quando haviam camaristas, ou seja, membros das câmaras de vereadores, que “assinavam em cruz"?

Mais do que uma questão de habilidades técnicas, o artigo “A Reforma Eleitoral” da edição de 12 de janeiro de 1881, deixa claro que o que estava em jogo era a defesa do mando para um determinado extrato social. Logo de início, o colaborador expõe o pertencimento escravocrata do conselheiro Saraiva, responsável pela reforma, ao afirmar, ironicamente, que ele não teria abandonado “(...) em vão o cafezal de sua fazenda e seus pretinhos”. Esforço pelo qual, receberia um lugar nos “(...) anais de nossa mísera história parlamentar”. O artigo mostra que, na contramão da representação direta instituída pela reforma, o Sr. Saraiva, usando seu tino, teria feito passar o artigo oitavo que “(...) excluía a maior parte dos legítimos cidadãos, que mais concorrem para o engrandecimento da pátria”. Sarcasticamente, dialoga ainda com o conselheiro, oferecendo-lhe a alternativa, caso a reforma não desse certo, e as irregularidades nas eleições continuassem, mesmo após caçado o direito do operário por seu "despreparo" e "inconsciência", ainda poderia apelar a por culpa na “(...) inconsciência dos libertos, naturalizados e acatólicos...” antes impedidos de votar e após a reforma permitidos, desde que se enquadrassem nos demais critérios.

A Gazeta valorizava a instrução e a organização do trabalho, o espírito de associação dos

25 Gazeta Operária, 8 de janeiro de 1881.

26 Idem.

27 É interessante notar dois aspectos que serão melhor discutidos no último capítulo. Primeiro no título da seção: "Corre por Aí", que mostra o forte vínculo mantido na produção dos impressos operários entre a escrita e a oralidade (característica da imprensa, em geral, nesse momento, tem grande destaque no universo pesquisado). Segundo, na escrita irônica, usada abundantemente, com objetivo de crítica, nos periódicos de trabalhadores. 
trabalhadores como meio do operário inserir-se e obter reconhecimento da sociedade. Sem maiores dados sobre o periódico do que os expostos em suas páginas, podemos supor, por alguns indícios, como citações recorrentes sobre a situação nas "oficinas do governo", que seus promotores tivessem vínculos, ou fossem eles mesmos, artistas nestas oficinas. Eles não pretendiam transformações no sistema socioeconômico e político do país. A crítica feita à exclusão operada pela reforma eleitoral ia no sentido de garantir o direito ao operário participar “(...) com as demais corporações, prestar o nosso voto na solução dos problemas que se agitam no país”28. Declaravam-se “(...) neutros nos interesses partidários, sem nos inclinarmos a essa ou aquela crença política”. Colocavam-se na luta pelos interesses e direitos do "elemento operário", enquanto "representantes do proletarismo".

Posicionamento bem distinto era o de A Revolução, o segundo jornal onde foi possível encontrar artigos sobre a reforma. Também produzido no Rio de Janeiro, o encontramos em duas épocas: de abril a maio de 1881 e em setembro de 1882. Na primeira época editado na tipografia da Revolução e na segunda em tipografia particular. A tipografia pertencia a Favilla Nunes, ao que tudo indica, o próprio redator do jornal. Os exemplares se encontram bastante mutilados. Trata-se de um órgão de propaganda republicana radical, assim caracterizado por ele mesmo ao mapear a "Imprensa Revolucionária no Brasil".

Os partidos oficiais predestinados a subirem alternativamente ao poder por ato espontâneo da coroa, não podem manter um só órgão se quer na imprensa, enquanto as opiniões políticas extraoficiais ou independentes contam os sete seguintes: os dois diários - Gazeta de Notícias e Gazeta da Tarde, e os periódicos a Pátria, o Corsário, o Tagarela, a Revolução e o Combate. Os dois diários e a Pátria são de tendências republicanas, mais ou menos francas, posto que de variados matizes; os outros quatro periódicos pregam abertamente a República ${ }^{29}$.

Como podemos ver, A Revolução colocava-se entre os órgãos que "pregam abertamente a República". No mesmo artigo, identifica os redatores e patrocinadores destas folhas que “certamente" não seriam senadores ou deputados, mas iam “(...) desde os pobres artistas operários até os ricos comerciantes e os homens de letras mais ilustrados". Os grandes apelos de sua propaganda seriam, assim, dirigidos "ao povo", conclamando-o à revolução, entendida como derrubada violenta da monarquia. Reconhece, porém, as especificidades deste intento no Brasil. "Somos revolucionários e temos um objetivo: o governo do povo pelo povo; poderíamos ser niilistas se houvesse paralelo entre a Rússia e o Brasil, lá um rei despótico, porém corajoso e destemido, aqui um rei constitucional por ficção e covarde por astúcia, para aquele uma bomba,

28 Gazeta Operária. 8 de janeiro de 1881.

29 A Revolução. 11 de abril de 1881. 
para este um pontapé"30.

No artigo "Rebelião", de 28 de abril de 1881, justifica a necessidade da revolução em função da espoliação à "infeliz pátria” por “(...) um rei safado, sem brio, sem dignidade, sem patriotismo, por um governo imoral (...) por uma canalha graúda que vive roubando os dinheiros públicos e o suor do povo: por uma aristocracia messalina". Ao se furtar da intenção de levar a propaganda revolucionária até os monarquistas ferrenhos, ou aos cidadãos indiferentes, delimita o escopo de sua "missão (...) somente com o povo, mas com o povo miúdo, com o zé povinho a quem pertencemos e de onde viemos".

Num momento de formação das classes trabalhadoras em processo ${ }^{31}$, não estava plenamente definida a identidade deste "povo miúdo", estabelecido no artigo em oposição ao "rei sem brio", à "canalha graúda" e à "aristocracia messalina". Diferente de outros periódicos ligados a associações de trabalhadores por ofício, ou com caráter mais amplo de auxílio mútuo e beneficência, a pauta de A Revolução era, primordialmente, política. Assim que se posiciona contra a reforma eleitoral. Porém, o principal artigo publicado sobre o tema não é de redação própria, mas sim transcrito d' $O$ Cruzeiro, como ao final podemos ler entre parêntese "Ineditorial do Cruzeiro". O artigo intitula-se “A Reforma e os Operários” e foi publicado em 7 de abril de 1881.

O texto coincide em teor com a crítica de Gazeta Operária, A Revolução ao reconhecer a exclusão política com caráter socioeconômico perpetrada pela reforma. A interpretação dada à constituição pela “ (...) administração, o Conselho de Estado, os magistrados (...)” ao afastar do voto “(...) o maquinista, o pequeno fabricante, o tipógrafo, o pintor, o caixeiro, os industriais honestos e trabalhadores que carecem de ser instruídos para exercer os ofícios e que tem incontestavelmente o décuplo da renda marcada pela constituição ${ }^{32}$..." gerava como consequência a seguinte divisão política no país: “(...) de um lado, 200.000 aristocratas privilegiados, políticos e empregados públicos, capitalistas e proprietários e de outro lado, 1.800 .000 despojados de seus direitos e reduzidos à escravidão política". Isso significaria a condução política do país contra os interesses da maioria trabalhadora, em favor das classes privilegiadas: “(...) a prisão pelo menor capricho, a condenação nas lutas judiciais, o próximo imposto de captação, o aumento de todos os encargos em favor da classe privilegiada.... ${ }^{, 33}$.

Da mesma forma que Gazeta Operária aponta como motivo alegado para reforma o de “(...) acabar com a influência das classes iletradas e proletárias que eram meros instrumentos nas mãos

30 A Revolução. 7 de abril de 1881.

31 O Processo de formação da classes trabalhadora é assunto a ser discutido, do ponto de vista da educação, no segundo capítulo desta tese.

32 A Reforma Eleitoral vinha, entre outros motivos, corrigir a renda "defasada" que havia sido estipulada pela constituição.

33 A Revolução, 7 de abril de 1881. 
dos cabos políticos”. E como aquele periódico, sai em defesa da imagem de caixeiros e operários. Porém, para valorizar àqueles, procura os distinguir de outras parcelas das classes populares, tratadas de forma pejorativa no artigo. Onde se lê: "Será aplicável essa classificação [de inconscientes] às honrosas classes de caixeiros e operários? Não de certo. Tratava-se dos capangas eleitorais, capoeiras e faquistas, satélites dos potentados das roças e de libertos vadios. Não é possível equiparar as verdadeiras classes populares a essa minoria ociosa e turbulenta das cidades e do mato..."34.

Por fim, o redator conclama a uma reação ativa dos operários para reaverem o direito que lhe tinha sido tomado, para o que precisariam se organizar. "Se as classes dos caixeiros e operários querem reaver a habilitação de cidadãos brasileiros que perderam, devem associar-se para obterem sufrágio universal dos homens de trabalho unido a representação direta e distrital" ${ }^{35}$. Chama ainda os "deputados do povo", aqueles que deveriam guiar a nação, "gente tão boa como os incapazes portadores de pergaminho". Não seria todo o povo, mas "os artistas e empregados do comércio". O “critério", parafraseando o título do artigo de Gazeta Operária, seria o trabalho, especialmente o trabalho formal. Como já foi dito, este era o "Ineditorial do Cruzeiro". O tom do próprio $A$ Revolução sobre a reforma seria mais enérgico ao afirmar que "Os direitos dos cidadãos ativos da sociedade, dos artistas e operários que são o sustentáculo do Estado, foram espoliados pelas reformas tolas e estúpidas...” e assim propor “(...) para os reconquistarmos precisamos empunhar o bacamarte na praça pública bradando: REVOLUÇÃO!"36.

Estas lutas políticas eram perpassadas pela questão da definição e distribuição dos saberes legítimos. Destas lutas derivou uma concepção hegemônica de analfabetismo usada como prerrogativa para exclusão social, com marcada face étnica, tanto da participação política quanto dos bens materiais e imateriais socialmente produzidos. É no contexto de implantação da chamada forma escolar no Brasil, em meio ao debate sobre civilização, progresso material e educação do povo, inclusive adultos analfabetos que vemos a criação e difusão de uma das mais arraigadas mitologias sociais modernas em nosso país: a da relação direta entre alfabetismo e capacidade de exercício da cidadania política. Concepção e tratamento do analfabetismo que produziram profundas marcas psicológicas e psicossomáticas como mostra o depoimento citado por Galvão e Di Pierro em livro no qual discutem o preconceito contra o analfabeto.

Ser pobre não é defeito, para mim é orgulho. Agora, não saber é um defeito, igual defeito físico, quando você chega num lugar, a pessoa olha pra você e já enxerga logo. (...) Parece que a gente pensa que está escrito na testa da gente. Porque tudo em cima da gente muda. O jeito da gente caminhar, o

34 A Revolução. 28 de abril de 1881.

35 Idem.

36 A Revolução. 15 de abril de 1881. 
jeito da gente pegar numa coisa, o jeito da gente se sentar na mesa, o jeito gente se servir. Quando a gente vai falar uma coisa a pessoa não entende do jeito que a gente fala, porque as vezes a gente fala de um jeito, quem sabe ler fala de outro jeito. Muda nem que seja uma letra, seja lá o que for, aí a gente fica com medo. Na hora que a gente entra num lugar só pensa que está todo mundo olhando para a gente, achando que a gente é, sei lá, um tipo de bicho, um marginal. Sinceramente, eu me sinto assim. (Caxias, Maranhão) (Citado em Brasil 2003: 20 e 27) (GALVÃO \& DI PIERRO, 2007, p. 20).

As persistentes marcas expressas no depoimento vêm, desde, pelo menos dois séculos, abalando a humanidade de sujeitos que se sentem como "um tipo de bicho" por não saberem ler e escrever. Acreditamos que a gênese de tão arraigado preconceito se encontram na gestação do nosso sistema político, do nosso sistema educacional, em suma, junto a formação de nossa própria nacionalidade. Vemos, a seguir, um discurso bastante representativo desta mitologia, no momento mesmo em que ela era instaurada, a justificativa do então ministro dos negócios do Império, Carlos Leôncio de Carvalho para seu decreto 7031 A de 1878 que instituía os cursos noturnos para adultos nas escolas públicas do município da Corte. Não fosse pela data e pelo vocabulário, estaria em condições de conquistar muitos adeptos ainda hoje.

$\mathrm{Na}$ distribuição do ensino, fora injusto o Estado, se, atendendo exclusivamente às gerações que despontam, deixasse no olvido aquela que já ocupa um lugar na cena política do país e que conta em seu seio uma numerosa classe completamente deserdada do benefício da instrução. Faz-se mister, portanto, ao lado das escolas destinadas a infância, promover a criação de cursos para o ensino primário dos adultos analfabetos, e esta necessidade assume uma importância particular quando trata-se da realização de uma reforma como a do sistema eleitoral, para cujo êxito poderosamente contribuirá o desenvolvimento da instrução popular. (...)

No seio dos povos livres nada há tão digno de compaixão como o adulto analfabeto, isto é, o homem que, adiantado na vida física, mas alheio às evoluções da vida moral, está separado da comunhão social pelo negro abismo da ignorância. Sabemos todos que a magna aspiração das sociedades modernas consiste principalmente em alargar, quanto possível, o círculo dos seus associados, pela igualdade no exercício dos direitos e no cumprimento dos deveres. Como, porém, realizar tão nobre aspiração, sem que a noção desses direitos e deveres haja penetrado mais ou menos profundamente a consciência e a razão de todos?

Como garantir um direito a quem não o sabe exercer e impor uma obrigação a quem não pode cumprir? Foi atendendo a essas considerações que empreendi e levei a efeito a criação dos mencionados cursos. A medida foi realizada com a máxima economia para os cofres públicos, visto que os cursos, como já fiz ver, funcionam nas casas ocupadas pelas escolas públicas, e o ensino é ministrado pelos professores das mesmas escolas, mediante razoável gratificação pelo excesso de trabalho ${ }^{37}$.

37 Relatório do Ministro dos Negócios do Império, Leôncio de Carvalho, 1878. Disponível em http://brazil.crl.edu/bsd/bsd/hartness/minopen.html. Grifos meus. 
Confluem as lógicas de 2003 e 1878. Adultos analfabetos estariam separados da comunhão social. O que confere humanidade ao homem e a mulher, se não a "comunhão social"? A justificativa de Leôncio de Carvalho concentrava-se na demonstração da "função formativa do cidadão" pelos cursos, frente a reforma eleitoral. Esta que viria corrigir o fato da renda fixada pela constituição para determinação dos votantes estar defasada era almejada desde antes de 1881. Segundo João Alfredo, também ministro dos negócios do Império, em relatório de 1871,

A quantia que ela [a Constituição] estabeleceu não tendo hoje o mesmo significado real, não pode conservar-se como condição permanente e única da capacidade eleitoral, sem que daí resulte alargar-se demasiadamente esta capacidade, abrangendo-se nela a quase totalidade da população, e convertendo-se em última análise o direito eleitoral em sufrágio quase universal.

Vemos assim uma medida de controle de conflitos e manutenção do poder instituído parecer um ato progressista e humanitário. Ao lutar pela liberdade dos povos, Leôncio de Carvalho assinalava que o exercício da liberdade não poderia se efetivar em uma "sociedade ignorante". A já citada confusão entre instrução e capacidade intelectual. Opunha-se o saber oficial à suposta falta de saber popular, que também implicava em incapacidade de discernimento político, enquanto ratificava o lugar da "escola governamental" como única fonte de saber válido. Deste modo, quem não passasse por ela não saberia exercer seus direitos e deveres, logo não seria digno deles.

É, porém, em sua ressalva final que o discurso insinua toda sua contradição interna. Uma medida tão utilitária, humanitária, e crucial para a vida política da nação apresentava como princípio a máxima economia para os cofres públicos. No tempo e no espaço e com os recursos que sobrassem, o Estado poderia exercer toda sua compaixão ao adulto analfabeto. Este, por sua vez, deveria ser grato e não reclamar caso não estivesse habilitado para exercer seus direitos - o voto pois lhe fora dada a oportunidade. Lá estavam - cursos noturnos de instrução primária para adultos. Os que permanecessem analfabetos, o seriam por vontade própria, afinal eram livres até para optar entre a "luz da razão" e as "trevas da ignorância".

Não apenas ministros monarquistas como Leôncio de Carvalho e João Alfredo Corrêa nutriam esse misto de "pena" e "desconfiança" em relação aos sujeitos focalizados. José Murilo de Carvalho (2006) nos mostra que mesmo os republicanos, idealizadores de um regime democrático, mantiveram incrustados tais preconceitos em relação às classes populares. Preconceitos, como por definição, fruto do desconhecimento, verdadeira ignorância, ignorância do que se teme. Desiludido com a República controlada pelas oligarquias terratenentes, é Raul Pompéia que afirma: "Desenganam-se os idealistas: o povo fluminense não existe. [...] Dirão que povo fez a agitação abolicionista, a agitação republicana [...]. O povo não fez nada disso. Um grupo de homens 
denodados, bastante ativos, é certo...". Ao que Carvalho questiona se a percebida inexistência de povo não era consequência do tipo de povo e de cidadão que se buscava.

Referindo-se à Revolta da Vacina, uma das revoltas populares mais impressionantes do Brasil republicano, o autor expõe qual seria o temor, mesmo de intelectuais, segundo ele, progressistas como Rui Barbosa e Olavo Bilac. Ao caracterizarem os revoltosos atribuem a revolta “às massas incultas que se teriam deixado levar à mazorca, segundo Rui. E, para Bilac, à "matula desenfreada" e os "ignorantes explorados pelos astutos", ou ainda, "uma turba-multa irresponsável de analfabetos". (CARVALHO, 2006) Em tais discursos circulantes na imprensa da época está marcado o papel da educação formal, monopolizada pelo Estado e embalada na ideologia da civilização, como critério de hierarquização social e desqualificação política da massa da população considerada analfabeta. $^{38}$

Qual seria então, o sentido da luta popular por escola quando tal instituição controlava, hierarquizava e desqualificava seus saberes? Discutindo o uso do costume como forma de resistência dos trabalhadores ingleses no século XVIII, quando grande parte da historiografia marxista relegava-o ao descaso, por considerá-lo um traço conservador só superado pelo movimento operário industrial, E. P. Thompson (2008) mostra ambiguidades que também podem nos ajudar a pensar a relação das classes populares com a educação no Rio de Janeiro oitocentista. "Uma cultura tradicional que é ao mesmo tempo rebelde", ou "duas consciências teóricas derivadas de dois aspectos da mesma realidade".

De um lado a, conformidade com o status quo, necessária para a sobrevivência, necessidade de seguir a ordenação do mundo e de jogar de acordo com as regras impostas pelos empregadores, os fiscais dos pobres, etc. De outro lado, o "senso comum", derivado da experiência da exploração, dificuldades e repressão compartilhada com os companheiros de trabalho e os vizinhos, que expõe continuamente o texto do teatro paternalista [referência à classe dominante da Inglaterra setecentista] à crítica irônica e, com menos frequência, à revolta. (THOMPSON, 2008, p.21)

Da mesma forma, não é provável que mães e pais de crianças pobres, gostassem de prescindir da ajuda de seus filhos no trabalho doméstico ou mesmo no trabalho remunerado, nem que adultos gostassem de usar suas horas de "descanso" para aprender a ler e a escrever durante a noite, ou que uns e outros concordassem com estigmas sobre sua inteligência e capacidade reproduzidos por algum professor menos gentil. Entretanto, ainda numa perspectiva thompsoniana, trata-se de um cálculo entre expectativas e necessidades. O modelo de escola implantado pelo

38 O espírito das mudanças eleitorais republicanas era o mesmo de 1881[estabelecia o critério de alfabetização, além da renda para tornar-se eleitor], quando foi introduzida a eleição direta. Até esta última data o processo indireto permitia razoável nível de participação no processo eleitoral, em torno de $10 \%$ da população total. A eleição direta reduziu este número para menos de $1 \%$. Com a República houve o aumento pouco significativo para $2 \%$ da população. 
Estado imperial fez-se vitorioso, logo o novo contexto exigiu uma nova conformidade da luta havia que se obter a mesma escolarização que as outras classes da sociedade possuem, ou aquela que, numa racionalidade realista, possibilite melhores perspectivas de sobrevivência e trânsito naquela sociedade.

Em sua reflexão sobre as relações entre alfabetização e desenvolvimento socioeconômico, ordem social e progresso individual Harvey J. Graff desmistifica o poder conferido, nos dois últimos séculos, a esta que seria nada mais nada menos que uma tecnologia ou um conjunto de técnicas para a comunicação e decodificação de materiais escritos ou impressos. Ciente de que na imaginação popular, a alfabetização é uma das características distintivas mais importantes de um homem civilizado e de uma sociedade civilizada e da suposição da analfabetização como um problema de consequências terríveis, sustentada não apenas por leigos, mas também implícita nos trabalhos dos estudiosos (OLSON, 1975-1976, apud GRAFF, p. 25) o autor defende, baseado em estudos históricos, que não existe uma correlação simplista entre alfabetização e melhores ganhos, maior civilidade, mais participação dos cidadãos em formas superiores de pensamento. O próprio processo industrial e a transição para o sistema fabril teriam dependido muito pouco dela. O que ocorre segundo ele é que o mito da alfabetização como chave para resolução dos problemas sociais teria levado a sua supervalorização por si mesma removendo-a do contexto sociocultural.

Em seu trabalho de desmistificação, o autor afirma antropologicamente que o uso do código escrito não é fator de superioridade intelectual. Basta lembrarmos que das mais de 4000 línguas do mundo, cerca de 300 fazem uso regular da forma escrita. Esta seria uma questão muito mais cultural dessas sociedades que uma questão econômica ou política. E recorrendo a história, mostra que até a década de 1960, o sentido do conceito e do fato da alfabetização estavam de acordo com a teoria da modernização. Era concebida como variável central que diferenciava sociedades mais e menos avançadas e desenvolvidas. Era também vista como variável independente. Tinha a ver com a ideia de infalibilidade e linearidade do progresso e com a crença na ligação entre alfabetização e outros indicadores de desenvolvimento social.

Porém, nos últimos anos da década de 80, já não haveria uma teoria consensual sobre alfabetização. A própria dificuldade de mensurá-la, comparar medidas e índices para diferentes lugares e períodos, as rápidas mudanças nas tecnologias de comunicação, a atenção internacional e os apelos da UNESCO por campanhas de alfabetização no terceiro mundo, reacenderam o debate sobre o tema. A alfabetização passou a ser vista como fio que ligava várias temáticas, bem como um assunto de natureza ideológica. "A palavra alfabetização (...) como conceito, princípio, condição, meta, etc. é ela mesma o produto de sua história” (GRAFF, 1995, p. 17).

Ainda vemos, porém, posições ideológicas opostas como as capitalistas e socialistas ou 
comunistas, e posições teóricas também opostas que defendem, uma a alfabetização mecânica e outra orientada politicamente, comungarem do chamado "mito da alfabetização", ou da supervalorização de seu poder. Ecos de um debate retomado por Graff que, voltando à história, observa argumentos de conservadores e liberais, no século XIX, quando divergiam sobre a educação a ser dada ao povo. Os conservadores consideravam os perigos de alfabetizar as massas temendo que elas se tornassem rebeldes ao trabalho manual e a ordem social. Já os liberais defendiam que a educação do povo era a melhor forma de controle social.

A ideologia liberal saiu vitoriosa e ganhou status de consenso. "Esta visão enfatizava objetivos sociais agregados: a redução do crime e da desordem, a assimilação de valores morais e, em uma extensão mais limitada, a ampliação da produtividade econômica... A alfabetização dificilmente era um objetivo, pois, islado da base moral, era temida como potencialmente muito perigosa" (GRAFF, 1995, p.67 e 68). O que venceu foi uma eficiente substituição à condescendência e ao paternalismo (um conceito chave), na qual a educação produziria disciplina e auxílio ao inculcamento dos valores e hábitos exigidos em uma sociedade urbana industrial.

Os trabalhadores também teriam se inserido neste debate, onde suas representações estariam marcadas por uma tensão entre a "fome" pela escolarização pública e as dúvidas sobre o valor daquela forma de educação. A educação representaria para eles algo mais do que a formação de trabalhadores melhores (GRAFF, 1995, p. 210). Ao analisar jornais operários norte americanos do século XIX, o autor mostra o quanto estes desejavam a educação formal e como o oferecimento desta educação teve influências sobre a redução da quantidade de trabalho infantil, diminuindo assim a concorrência de uma mão de obra barata e dando mais respeitabilidade ao trabalho.

A educação cortou dois caminhos em seus benefícios aos trabalhadores: foi valiosa na elevação e manutenção dos salários e padrões de trabalho, ao mesmo tempo em que restringia a oferta de trabalhadores. Contudo, simultaneamente, trabalhadores educados, trabalhadores especializados e trabalhadores morais, fizeram o trabalho ser respeitado, além de lucrativo. Podemos duvidar que o respeito fosse menos importante do que o lucro (GRAFF, 1995, p. 210).

Ao ter em vista os usos da educação direcionada pelos interesses das classes trabalhadoras, encontramos a inversão do que representaria, na ideologia liberal dominante, uma ferramenta de ascensão e melhoramento individual (os ganhos para o progresso social e o desenvolvimento econômico viriam pelo fato de uma sociedade ser considerada por aquela ideologia como um agregado de indivíduos) a tornar-se um instrumento de luta coletiva, de luta de classes. Uma ferramenta importante, dependente dos usos dela feitos, mas ainda uma ferramenta com seus limites, como podemos perceber no questionamento que se segue.

$\mathrm{O}$ que aconteceria se o mundo inteiro se tornasse alfabetizado? Resposta: 
não muita coisa, pois o mundo é, em grande medida, estruturado de forma tal que é capaz de absorver o impacto. Mas se o mundo consistisse de pessoas alfabetizadas, autônomas, críticas, construtivas, capazes de traduzir as ideias em ação, individual ou coletivamente - então o mundo mudaria. A alfabetização não é o único problema. Ela também não é a única solução (GRAFF, 1995, p. 52).

Em consonância com a crítica realizada por Graff e tendo como ponto de apoio a teoria da história exercida por Thompson, que acrescenta ao materialismo histórico o "termo ausente": a experiência humana, as ideias aqui esboçadas sobre um papel ativo, um educar-se das classes populares oitocentistas pretendem contribuir com a derruba da tese da incapacidade política desses sujeitos, mostrando como a aprendizagem do código alfabético e outros saberes escolarizados não é uma condição indispensável para a interpretação do mundo à volta e para a tomada de decisões sobre a vida coletiva, mas que, de toda forma, é uma ferramenta útil. Pois que "até mesmo esses monstruosos aparelhos, a família e escola têm uma ou duas funções subsidiárias à função de repressão"39. (THOMPSON, 1981, p. 198)

Ainda que os sujeitos aqui estudados não tenham emplacado projetos de educação e sociedade vencedores, eles não deixaram de imaginá-los, propagá-los e, em certa medida, influenciaram seu tempo e, cumulativamente, a nossa história educacional. Ao estudar aquilo que, de um ponto de vista, não passava de ideias e episódios secundários na Revolução Inglesa: “(...) a tentativa de vários grupos formados em torno à gente simples do povo para imporem suas próprias soluções aos problemas de seu tempo, em oposição aos propósitos de seus melhores que os haviam chamado a ingressar na ação política" (HILL, 1987, p. 30), C. Hill nos ensina que, mesmo sendo sempre os letrados a compor o discurso oficial sobre a educação do povo, ou os alfabetizados a delimitarem os analfabetos, cabe buscarmos o próprio discurso das classes populares sobre sua educação. Uma vez que "O historiador se interessa pelas ideias não apenas porque elas influenciam as sociedades, mas também porque são reveladores das sociedades que as originaram..." (HILL, 1987, p. 35). Dessa forma, ainda que não tenham sido as associações de trabalhadores com seus periódicos, nem os "pais de família" ou "chefes de família” promotores de abaixo-assinados a definir os rumos da política educacional do Estado imperial, tampouco do republicano, isso não invalida seu papel histórico e os significados de sua luta por educação.

Tendo nossos olhos bem abertos e dependendo do direcionamento de nossas pesquisas, podemos encontrar um povo menos submisso do que costumamos supor. Ainda que os momentos de ativação de seu poder tenham sido pontuais, as classes populares chegaram mesmo a elaborar algumas teorias contra hegemônicas. No caso dos sujeitos abordados nesta tese, podemos encontrar

39 Cabe alertar para que não se perca a ironia quanto aos "monstruosos aparelhos" de hegemonia no trecho citado contida na crítica de Thompson a Althusser, centro da obra "A miséria da Teoria". 
tais elaborações teóricas em jornais de trabalhadores na segunda metade do século XIX. Podemos pensar ainda o sentido da rebeldia dentro das possibilidades históricas. É rebelde preservar a vida por socorros mútuos quando a ordem prescreve a dependência paternalista, a insegurança social e a ausência de direitos. É rebelde procurar educar-se quando a ordem prescreve a educação segregada e o analfabetismo. E, guardadas todas as proporções dos contextos históricos, podemos encontrar inspirações para nossa análise na experiência humana em sentido mais amplo quando Hill nos mostra que:

O povo comum ... teve uma participação inusitada nas eleições para os dois parlamentos em 1640 votando contra a corte - e muitas vezes exibindo também um elemento de hostilidade de classe. (...) Em Exess, um homem do 'povo vulgar e rude' ameaçou 'fazer os fidalgos em pedaços', se o candidato popular não fosse eleito para representar o condado. Em Great Marlow, barraqueiros, assalariados, lojistas, 'o tipo normal de citadinos' liderados por um 'campônio de roupa comum e mesquinha' - apresentaram um candidato próprio contra o senhor rural local que tinha conexões na corte, ganharam as eleições. (...) Além das tensões de classe, ou expressando-as, havia uma tradição plebeia de anti clericalismo e irreligião. Se organizavam em comunidades como a que foi classificada como anabatista. Defendiam que as crianças não deveriam ser batizadas (o batismo seria um ato voluntário do adulto). Eram contra os dízimos, uns rejeitavam as guerras e o serviço militar. Alguns eram igualitaristas a ponto de rejeitarem a propriedade privada. $\mathrm{O}$ nome anabatista veio a ser usado num sentido pejorativo genérico para referir-se àqueles que acreditava-se opunham-se à ordem social e política vigente (HILL, 1987, p. 39 e 44).

Ao lermos $O$ mundo de ponta cabeça, percebemos o quanto as questões políticas, sociais e em meio a elas as educacionais estavam pautadas, há muito tempo, nas lutas das classes populares. $\mathrm{O}$ autor inglês também nos instiga a comparar movimento social / lutas sociais e políticas com escolas, espaço de aprendizado, ao afirmar que o Exército de Novo Tipo (que lutou em defesa do parlamento contra a monarquia durante a Revolução Inglesa) fora uma efêmera escola de democracia política, ao passo que os comunais, as terras abandonadas e as florestas constituíram escolas mais duradouras, embora menos intensivas de democracia econômica. (HILL, 1987, p. 136).

Ao mesmo tempo, encontramos a consciência popular sobre a relação entre saber e poder político. Na abertura do sexto capítulo do, já citado, $O$ mundo de ponta cabeça, a fonte transcrita explicita, de maneira como hoje não vemos mais, o embricamento entre poder de Estado, conhecimento e riqueza. Trata-se de um escrito de William Walwyn, a "Predição da Conversação e Abjuração do Sr. Edwards", autor de "Gangraena", livro de 1646, que catalogava seitas hereges na Inglaterra.

[Escrevi Gangraena] por orgulho e vaidade do meu espírito, por desprezar os homens simples e sem estudo que tentam obter conhecimento por alguma via diferente de nós... a perder o domínio que exercemos devido a sermos os 
únicos juízes em matéria de doutrina e disciplina, graças a que nossos predecessores foram suseranos de Estados e Reinos, e finalmente de que assim viéssemos a perder as vantagens e o fausto em que vivemos graças aos dízimos... Tudo isso eu vi chegar junto com essa liberdade que os homens comuns foram tomando de querer investigar todas as coisas... (HILL, 1987, p. 99).

Havia, por um lado, a repressão à autonomia intelectual do povo, por outro, a luta deste mesmo contra o monopólio das verdades. O saber legítimo no século XVI era o saber religioso, para manter seu domínio a religião oficial vai reprimir os sujeitos que criticavam e investigavam as verdades cristalizadas. "'A religião é o único alicerce firme para todo o poder' dissera Carlos I. 'A Igreja e o Estado apoiam-se e assistem-se mutuamente', escreveu o bispo Godman. O Estado paga ao clero e assim este depende do Estado, afirmou com mais crueza Hugh Peter. A função de uma Igreja Estatal não se esgotava em orientar os homens para o céu: consistia também em mantê-los subordinados aqui na terra" (HILL, 1987, p. 110). Mais tarde será o saber científico a cumprir o papel antes cumprido, na ordem política, pelo saber religioso.

Segundo Hill, os leitores comuns da bíblia durante os séculos XVI e XVII queriam democratizar os mistérios guardados pelo clero abolindo todo tipo de charlatão da linguagem, quer se tratasse de sacerdotes, advogados ou eruditos. "Acreditavam eles (...) que qualquer um poderia compreender o verbo de Deus, bastando estudá-lo com cuidado e ter dentro de si a graça divina (...). Pois os anos de 1640 e 50 foram a grande época dos 'pregadores operários', leigos como Bunyan, que interpretavam a Bíblia com luzes de autodidatas (...) 'Sou como Paulo deste tempo', exclamava Evans; 'ele era um trabalhador, fabricante de tendas, como diz nos atos dos apóstolos, XVIII, v. 3. Eu sou alfaiate. 'Homens pobres, analfabetos, trabalhadores' - dizia William Dell dos apóstolos - 'viraram o mundo de cabeça para baixo'” (HILL, 1987, p. 106).

O líder radical digger ${ }^{40}$ Winstanley também formulou sua explicação para a dominação do homem pelo homem desde o princípio da criação do mundo. Sua teoria estabelecia um paralelo entre ensinar e governar. Segundo ele,

No princípio dos tempos o grande criador, a Razão, fez a terra:...Porém...imaginações egoístas... impuseram um homem a ensinar e mandar em outros. (...) E assim a terra ... foi cercada pelos que ensinavam e governavam, e foram feito os outros ... escravos. E essa terra que na criação foi feita como um celeiro comum para todos, é comprada e vendida e conservada nas mãos de poucos, o que constitui enorme desonra para o criador...'. Winstanley dizia ainda aos senhores dos solares que foi pela espada que os vossos ancestrais introduziram na criação o poder de cercar a

40 Trabalhadores rurais pobres liderados por Gerrard Winstanley no período da Revolução Inglesa que pretendiam a transformação radical do sistema feudal e propunham um modelo de sociedade que se aproximava muito do que conhecemos como socialismo. Também se denominavam true levellers por pretenderem, além da igualdade política, a igualdade econômica. 
terra e fazer dela propriedade. (...) E, portanto, embora vós mesmos não tenhais pessoalmente roubado ou matado, se conservais essa coisa maldita em vossas mãos é pelo poder da espada... (HILL, 1987, p. 139 e 140).

Os radicais ingleses também elaboraram uma concepção de educação como intervenção organizada, como forma de direcionamento do processo formativo. Aos olhos de Winstanley a educação parecia ter a maior importância.

Deveria prosseguir até que travasse conhecimento com todas as artes e linguagens. Proposta excepcional no século XVII, ela seria universal (para ambos os sexos) e igual: não mais haveria eruditos especializados vivendo dos 'labores dos outros homens'... As crianças deveriam ser treinadas em ofícios e algum trabalho físico bem como aprenderiam línguas ou história'. As meninas estudariam música, aprenderiam a ler, costurar, tricotar e fiar. Haveria incentivos e recompensas para invenções e experiência novas. Até o presente momento, o medo, a pobreza e a preocupação de ter que pagar as taxas aos tiranos impediram que acontecesse muitas preciosas invenções. $\mathrm{O}$ poder régio esmagou a inspiração de conhecer e jamais permitiria que essa se alçasse em toda sua beleza e plenitude. (...) Os segredos das corporações de ofícios também abolidos. Assim, tudo contribuiria para que a República florescesse na paz e na abundância... (HILL, 1987, p. 144 e 145).

Apesar dos esforços dos radicais ingleses, novos encastelamentos do saber se estabeleceram:

...Desejaram tirar os teólogos escolásticos das universidades e por fim à hegemonia do latim, do grego, do hebreu, mas ao proporem isso tampouco queriam que a ciência caísse nas mãos de outro grupo dono de um jargão igualmente incompreensível. (...) Para o operário médio, Newton era tão incompreensível quanto Tomás de Aquino. O conhecimento não estava mais encerrado na Bíblia latina, que eruditos e eclesiásticos deveriam interpretar, mas ia se encerrando cada vez mais no vocabulário técnico das ciências que os novos especialistas deveriam interpretar (HILL, 1987, p. 287).

A realidade construída de hierarquias e saberes sociais herméticos viu, entre tempos e espaços as resistências dos sujeitos cujos conhecimentos eram desqualificados. Junto com Hill, afirmamos que, também no Brasil oitocentista, fazer política e produzir/comunicar conhecimentos, não se restringia ao sistema eleitoral e a forma escolar. Como derradeira argumentação a favor de uma valorização da experiência política popular, por hora, tomo de empréstimo a fonte localizada por Leila Duarte (2002) a partir da qual tece a impressionante história dos padeiros escravos e livres na virada do século XIX em sua luta por "pão e liberdade". A autora descobriu no Arquivo Público do Estado do Rio de Janeiro o Histórico Social escrito pelo padeiro João Mattos em 1934 e apreendido pela polícia política varguista nesta mesma época. O Histórico Social conta a ininterrupta luta de João e seus companheiros desde 1876 até a década de 30 do século XX. "Durante muitos anos João de Mattos foi líder de seu grupo e, com engenhosidade e ousadia, entre 1876 e 1888, conseguiu libertar alguns padeiros escravos e, até 1912, organizou algumas das 
primeiras associações de trabalhadores urbanos em São Paulo e Rio de Janeiro". Não se sabe se ele era ex-escravo, mas impressiona sua capacidade de escrever bem. (DUARTE, 2002, p. 19)

As informações oferecidas pela autora sobre esta trajetória nos permitem tomá-la como subsídio para algumas das hipóteses aqui desenvolvidas, começando pelo fato de ter chegado até nós por meio da escrita, e ao que ela indica, uma boa escrita. Vemos aí o domínio desta ferramenta e seu uso para produção consciente de uma memória que não é só do indivíduo, mas de acordo com seu título, é social.

No relato, João apresenta os motivos pelos quais ele e os companheiros teriam se envolvido em planos de libertação de escravos e como estes teriam sido operacionalizados, fazendo, novamente, uso da escrita. Foram duas as razões principais: 1- não admitir que se vendesse ou leiloasse pessoas como eles; 2- por acharem que enquanto houvesse homens livres e escravos trabalhando juntos os livres não teriam uma vida digna, com estabilidade, pois enquanto o escravo é uma mão-de-obra permanente, o livre pode ser demitido a qualquer momento. "Sempre haveria escravos para continuar o serviço". Assim o fim da escravidão traria benefícios tanto para trabalhadores escravos quanto para os livres. O contato que João possuía com os escravos das casas ao entregar pães de madrugada, que eram recebidos por aqueles, facilitava o conhecimento de seu cotidiano e as possíveis articulações de fugas. Ele e seus companheiros conceberam, então, o plano de falsificar cartas de alforria. A carta de alforria que a princípio exigia muitas informações e a formalidade do registro no cartório foi simplificada a partir de $1871 \mathrm{com}$ a Lei do Ventre Livre. Em seu plano, cada escravo, com a carta falsa em mãos, fugiria para fazendas distantes apresentando-se como trabalhador livre para conseguir emprego. Em 1876, houve o primeiro levante geral, uma greve em que todos os padeiros da cidade abandonaram seus postos e se dispersaram, possibilitando a fuga dos escravos com as cartas. Dois meses depois João foi preso em São Bernardo e conduzido a Santos.

Temos aí a formulação de coerentes concepções políticas a partir da análise do contexto socioeconômico - a escravidão degradava o trabalho escravo e o trabalho livre. A esta compreensão seguia-se a produção da estratégia de atuação - o término da escravidão por meio da libertação dos escravos e da tática - a falsificação das cartas de alforria, o levante geral dos padeiros e a fuga dos escravos para fazendas distantes. E como a ação dos padeiros não se tratava de um arrobo espontaneísta, depois de solto João Mattos deu continuidade ao plano de libertação. Dirigiu-se ao Rio de Janeiro e, em 1880, no Largo do Paço ele e companheiros organizaram o "Bloco de Combate dos Empregados de Padaria" com o lema: "Pelo Pão e Pela Liberdade".

Essas primeiras organizações de trabalhadores adotavam as denominações mais diversas: sociedade, associação, centro, liga, união e até "bloco de combate". Com a qualificação de "bloco de combate", João e seus 
companheiros queriam diferenciar sua entidade de sociedades mutualistas consideradas apenas como beneficentes, pois não combatiam as condições de trabalho e de vida dos trabalhadores. João sublinha em seu texto que a "única sociedade de classe de combate" era a dos padeiros.

Cada padeiro colaborava com uma pequena quantia para o aluguel de uma sala de reuniões. Pendurada na porta da entrada, uma tabuleta anunciava: "Curso de dança". Dessa forma os padeiros visavam não chamar a atenção da polícia e dos donos de escravos pois, como escreveu João, "era um crime terrível guerrear a propriedade escrava".

Antes da reunião começar os diretores daquele original curso de dança penduravam na parede 11 "bases sociais", uma espécie de estatuto da entidade. A primeira dessas bases era preparar "os espíritos dos companheiros, tanto escravizados como livres" para a rebeldia a fim de conseguirem a libertação dos escravos. A luta política dos negros era primeiro pela liberdade. (DUARTE, 2002, p. 36)

O trecho citado nos traz importantes informações sobre a prática política e intelectual destes sujeitos, parte integrante da complexidade aqui referida como "classes populares". Vemos que eles escolhiam nomes para suas organizações, fazendo assim opções políticas representadas de forma simbólica esperando que fossem interpretadas/compreendidas por seus pares, nos ensinando que a leitura vai além da decodificação de palavras. Vemos que empregavam recursos materiais em um projeto de longo prazo organizando e calculando finanças. E ainda, que o disfarce com a tabuleta do curso de dança era uma manobra para lidarem com as adversidades e fraquezas identificadas na interpretação das condições do embate político e da luta de classes. E quando, mesmo após a abolição João continua sua luta contra as péssimas condições de vida e de trabalho dos que chamou “escravizados livres”, compreendendo que a abolição e a República não trouxeram mudança efetiva para suas vidas, temos novamente a mostra da capacidade de análise sócio-política nacional, cunhando, inclusive, conceitos - "escravizados livres" - e adaptando novas estratégias à novas conjunturas.

Cada passo da história de João Mattos, por ele mesmo narrada e legada a nós por escrita de seu próprio punho contradiz o discurso de seu contemporâneo, o ministro Leôncio de Carvalho, anteriormente apresentado. Enquanto para o ministro, o adulto analfabeto é "digno de pena", "caído no negro abismo da ignorância", os padeiros provam que trabalhadores livres e escravos, homens supostamente analfabetos, eram capazes de se emancipar por meio de estratégias e táticas compostas a partir da interpretação de sua realidade e da realidade nacional e usando a escrita como ferramenta. Mostra ainda que as aspirações de igualdade em direitos e deveres atribuídas por Leôncio de Carvalho às sociedades modernas é em seu interior uma falácia, quando cada pequena conquista de direitos dos trabalhadores teve de ser arrancada baixo a repressão. Concluímos, então que se é verdade que o pior analfabeto é o analfabeto político, os padeiros estavam aprovados, pois sabiam fazer política para além do sistema eleitoral que após a reforma de 1881 teve de esperar até 
1988 pelo voto do cidadão analfabeto. Por fim, a história dos padeiros nos deixa supor que negro, como a cor da pele da maior parte dos sujeitos aqui tematizados, não era o "abismo da ignorância", mas os sonhos de liberdade e de uma vida melhor acalentados pelas classes populares oitocentistas. 


\section{Capítulo 2- Formas do educar-se nas organizações das classes trabalhadoras}

Mas fora dos recintos da Universidade, outro tipo de produção de conhecimento se processa o tempo todo. Não sou indiferente aos valores intelectuais nem inconsciente da dificuldade de se chegar a eles. Mas devo lembrar a um filósofo marxista, que conhecimentos se formaram e ainda

se formam for a dos procedimentos acadêmicos. E tampouco eles têm sido, no teste da prática, desprezíveis. Ajudaram homens e mulheres a trabalhar os campos, a construir casas e a manter complicadas organizações sociais, e mesmo, ocasionalmente, a questionar eficazmente as conclusões do pensamento acadêmico. (THOMPSON, E. P. A miséria da Teoria. Ou um planetário de erros. Uma crítica ao pensamento de Althusser).

Apesar do aprofundamento da separação escola e vida característico das sociedades modernas, o saber de experiência resiste. Para além da escola havia e há muitas formas de aprender, inclusive de aprender a cultura letrada. As associações de trabalhadores foram um espaço privilegiado para esse tipo de aprendizado entre meados do século XIX e início do século XX. Acompanhando-as podemos contar um pouco a história da educação das classes populares naquele período bem como a história da formação da classe trabalhadora no Brasil. Associando uma a outra, encontramos à participação da educação no processo de formação desta classe.

Trabalhos historiográficos recentes têm demonstrado a expansão do fenômeno associativo, no Brasil, durante o século XIX (BATALHA, 1999; BARATA, 1999; CHALHOUB, 2007; GONDRA \& SCHUELER, 2008; MOREL, 2005). Movimento de grande importância política e social, compunha-se por diversos formatos - confrarias, irmandades religiosas e leigas, academias, lojas maçônicas, grêmios, sociedades corporativas ou profissionais, beneficentes, filantrópicas, de auxílio mútuo, científicas, literárias, pedagógicas, institutos de pesquisa, a imprensa periódica, tipografias, editoras e livrarias, etc. Marco Morel (2005) assinala a necessidade e ao mesmo tempo a dificuldade de se estabelecer uma tipologia dessas associações heterogêneas, muitas vezes instáveis e efêmeras, em certos casos com múltiplos fins (beneficentes, pedagógicos, filantrópicos, religiosos, culturais, científicos, etc.).

Gondra e Schuler (2008) procuraram realizar uma sistematização das associações envolvidas com a prática pedagógica no império brasileiro. Classificando-as entre as forças educativas ao lado do Estado e da Igreja, destacam as mais proeminentes como a Sociedade Auxiliadora da Indústria Nacional; a Sociedade Amante da Instrução; a Sociedade Propagadora das Bellas Artes (promotora do Lyceo de Artes e Officios); a Sociedade Propagadora da Instrução para as Classes Operárias da Lagoa. Destacam, ainda, as Sociedades que ligavam abolicionismo e instrução, como é o caso do Club dos Libertos Contra a Escravidão, que além de promover alforrias de escravos, mantinha um curso noturno de instrução primária para livres, libertos e escravos. 
A educação mediava, dessa forma, a ação deliberada de determinados sujeitos: intelectuais, parlamentares, beneméritos, profissionais liberais, lideranças abolicionistas, lideranças trabalhadoras $^{41}$ e seus projetos mais ou menos sistemáticos sobre outros sujeitos anunciados como “o povo". O discurso educacional do Estado imperial enfatizava a importância do desenvolvimento da instrução popular como forma de elevar o Brasil ao concerto das nações civilizadas e, não raro, solicitava para isso a contribuição da iniciativa particular associada. Com ares de consenso encontramos entre a opinião pública da segunda metade do XIX um posicionamento muito próximo do que foi caracterizado por Nagle (1976), referindo-se à Primeira República, como entusiasmo pela educação e otimismo pedagógico. A questão que orienta este trabalho vai no sentido inverso: como seria enxergar "o povo" ou "as classes populares" não como objeto da educação, mas como sujeitos que atuam sobre ela, captar sua lutas por instrução, os momentos em que educam a si mesmos, os indícios de suas concepções sobre os significados e a importância atribuída à educação?

Em outras palavras, os intelectuais, parlamentares, beneméritos, profissionais liberais, lideranças abolicionistas e trabalhadoras oitocentistas nos responderiam sem muita dificuldade por que se deve educar o povo e talvez até o como, tendo em vista o vulto que assumiu tal debate, especialmente na segunda metade do século. Gostaria, agora, de escutar deste povo "porque deve procurar ou aceitar receber" a educação, uma vez que, de fato as classes populares a procuravam. E, de fato, podemos dizer que a ideia é de recepção, pois que a educação popular era vista mais como dádiva que como direito e os alunos eram menos produtores de cultura e saberes respeitáveis do que elementos a serem moldados e/ou regenerados.

A análise exposta no presente capítulo privilegia as associações constituídas por trabalhadores (mesmo que contassem em seus quadros com indivíduos de outros extratos sociais). São, em geral, associações de auxílio mútuo e beneficência, muitas delas organizadas por ofício. Ronaldo Pereira (1999), em pesquisa sobre o fundo do Conselho de Estado, depositado no Arquivo Nacional, classificou as associações promovidas por trabalhadores entre: categorias profissionais; associações de classe; de escravos libertos; e sociedades de auxílio mútuo ${ }^{42}$. Àquelas formadas com

41 Identificações não estanques porque algumas delas, na prática, se entrecruzavam em um mesmo indivíduo.

42 As associações classificadas por Pereira foram:

Categorias Profissionais:

1861 - Associação Nacional dos Artistas Brazileiros Trabalho União e Moralidade; 1861 - Associação Thipographica Fluminense; 1868 - Montepio dos Servidores do Estado; 1868 - Sociedade Animadora da Corporação dos Ourives; 1870 - Sociedade Protectora dos Artistas Dramáticos; 1870 - Sociedade Protectora dos Barbeiros e Cabellereiros; 1871 - Associação Dramatica e Beneficente dos Artistas; 1872 - Monte Pio dos Artistas; 1873 Associação Cooperadora dos Empregados da Thypografia Nacional; 1873 - Sociedade Beneficente do Commercio; 1873 - Sociedade Beneficente dos Machinistas; 1873 - Sociedade de Beneficência dos Artistas da Construção Naval; 1874 - Sociedade Philantropica dos Artistas; 1875 - Sociedade Beneficente dos Artistas em São Christovão; 1875 Sociedade Beneficente dos Marceneiros Carpinteiros e Artes; Correlativas no Rio de Janeiro; 1876 - Imperial Sociedade Auxiliadora das Artes Mechanicas e Liberaes; 1876 - Sociedade dos Artistas Alfaiates; 1877 - Sociedade de Socorros Mútuos dos Artistas Sapateiros e Profissões Correlatas; 1880 - Sociedade Beneficente dos Empregados da Gazeta de 
objetivos especificamente culturais e pedagógicos, mesmo que voltadas para as classes populares, na maioria das vezes empreendidas por beneméritos imbuídos de "sentimentos humanitários" ou “princípios civilizatórios" serão aqui tratadas em relação às primeiras.

Tal delimitação no universo da "sociedade civil", a princípio tematizada pela pesquisa de que se origina esta tese, tem a ver tanto com o interesse pela história das classes populares como pela amplitude inapreensível daquela onde se misturam iniciativas de educação "doada" ao povo e "conquistada" ou "promovida" por este. Não se trata de estabelecer uma separação estrita entre estes dois tipos de iniciativa educacional, nem de homogeneizar por um lado "o povo" e por outro “as elites”. É preciso compreender esses sujeitos em relação, nas complexas últimas décadas do século XIX, quando observamos, em meio ao processo de formação do Estado nacional, um momento de crise do sistema escravista e do regime imperial.

Podemos entender a formação das diversas associações como um momento de regulamentação da iniciativa privada tendo em conta que a crise citada assolava o sistema escravista e o regime monárquico, mas não necessariamente o poder público. Entendemos público como o que pertence a todo um povo, ou o que concerne ao Estado. O oposto ao privado. A res-pública engloba o domínio pertencente à coletividade, a res-privada encontra-se na dependência de um poder diferente, o do pater-famílias, principalmente exercido no quadro fechado da casa. O privado estaria no âmbito da família, ou de outros grupos fechados (ARIÈS \& DUBY, 1997).

A tensão e a própria indefiniç̧ão e imbricamento entre público e privado no período imperial deixou suas marcas nos processos aqui pesquisados. As permanências do poder privado herdado dos tempos coloniais e das relações paternalistas existentes numa sociedade escravista se expressavam no universo das próprias associações populares, seja em sua relação com a figura do imperador, ou suas relações internas entre sócios "bem feitores e beneméritos" e sócios "comuns". Tendendo a esgarçar-se, mas ainda vigente, o paternalismo do príncipe e suas formas correlatas eram reflexo da privatização. "Presume-se que todos o servem, todos invocam em troca de seu patronato, esperando

Noticias; 1880 - Soc. de Socorros Mútuos dos Empregados das Capatazias da Alfandega da Côrte; 1880 - Sociedade de Socorros Mútuos Montepio dos Machinistas; 1882 - Sociedade Beneficente dos Empregados no Fumo.

Associações de classe:

1872 - Liga Operária; 1882 - Corpo Colletivo União Operária;

Escravos Libertos:

1862 - Sociedade Beneficente Nação Conga - Amiga da Consciencia; 1871 - Sociedade União Lotérica Cadeira de Ouro; 1873 - Sociedade Beneficente Caldeira de Ferro - Sociedade Loterica; 1874 - Associação Beneficente Socorro Mútuo dos Homens de Cor

Sociedades de auxílios mútuos (populares):

1872 - Associação Asylo da Velhice Desvalida; 1872 - Sociedade Espanhola de Beneficência; 1873 Sociedade de Beneficiência e Socorros Mútuos Redempção; 1873 - Sociedade de Beneficiência Perfeita amizade; 1875 - Sociedade Asylo e Beneficência; 1875 - Sociedade Beneficente União e Fraternidade; 1875 - Sociedade de Socorros Mútuos Igualdade e Beneficência; 1876 - Sociedade Beneficente Caixa de Socorros Mútuos Pedro Segundo; 1876 Sociedade Beneficiente das Famílias Honestas; 1876 - Sociedade União e Beneficência; 1877 - Associação de Socorros Mútuos Phylantropia e Ordem; 1877 - Sociedade União Funerária Primeiro de Julho. 
ser defendidos... como por um pai, e ser também, ocasionalmente sustentados por ele..." (ARIÈS \& DUBY, 1997, p. 33).

Mas o desenvolvimento do Estado moderno é a afirmação do poder público. Se tomarmos a teoria política de Gramsci, temos que a formação do Estado traz consigo a formação da sociedade civil já que, para o filósofo italiano, o Estado é perpassado pelas relações sociais existentes numa formação social incorporando em si mesmo e arbitrando os conflitos vigentes. Seu Estado ampliado seria visto, assim, de forma triádica: como infraestrutura (relações de produção e de trabalho); como sociedade civil (conjunto de indivíduos organizados em aparelhos privados de hegemonia e cerne da ação/pressão política consciente); como sociedade política (Estado, aparelho e agências do poder público propriamente dito).

O Estado, integrado pela sociedade civil e pela sociedade política tem outra dimensão para além da força - a cultura - conjunto de visões de mundo, valores, crenças, auto percepções desenvolvidas por cada grupo social, mas só aqueles que estão organizados nos aparelhos privados de hegemonia. Os grupos que não estão, adotam como sua a visão de mundo de outro grupo dominante - esse é o princípio da hegemonia (MENDONÇA, 1998). E é esse princípio de hegemonia que nos leva a compreender a importância atribuída aos processos educacionais no âmbito das associações aqui estudadas. Os processos educacionais são um dos meios pelos quais os intelectuais, considerados por Gramsci “comissários dos grupos dominantes" viabilizam a hegemonia social, ou a disputam, principalmente o “(...) consenso 'espontâneo' dado pelas grandes massas da população à orientação impressa pelo grupo fundamental dominante à vida social" (GRAMSCI, 1982, p. 11).

Pressupondo a existência dos poderes público e privado e das esferas da sociedade civil e sociedade política como formadoras do Estado, tomo como foco de análise as relações de classe, ainda "frouxas" e não muito distintas, em vias de constituição de seus "aparelhos de hegemonia". É nesse contexto que pretendo observar o processo de formação da classe trabalhadora no Brasil mediado por suas concepções de educação e suas iniciativas educacionais. Mas o termo classe não é compreendido como um dado, surgido no ano $\mathrm{X}$, amadurecido no ano $\mathrm{Y}$ e, atualmente, como pregam algumas teorias sociais, termo obsoleto para uma realidade acabada. Classe é aqui pensada na perspectiva dinâmica inaugurada por E. P. Thompson, como "um fenômeno histórico, que unifica uma série de acontecimentos díspares e aparentemente desconectados tanto na matéria prima da experiência quanto da consciência. (...) Não vejo a classe como uma "estrutura", nem mesmo como uma categoria, mas como algo que ocorre efetivamente (e cuja ocorrência pode ser demonstrada) nas relações humanas" (THOMPSON, 2004, p. 9).

Chalhoub (2001) aponta o período de formação da classe trabalhadora no Rio de Janeiro 
entre 1870 e 1920. Segundo ele, para perceber esta formação seria necessário observar todas as esferas da vida do trabalhador, não só o mundo da produção. O autor defende ainda, que a luta de classes não se restringia aos movimentos organizados. Cita Lima Barreto em Recordações do Escrivão Isaías Caminha: "Admirava-me que essa gente pudesse viver lutando contra a fome, contra a moléstia, e contra a civilização, que tivesse energia para viver cercada de tantos males, de tantas privações e dificuldades. Não sei que estranha tenacidade a levava a viver e porque essa tenacidade é tanto mais forte quanto mais humilde e miserável” (CHALHOUB, 2001, p. 32).

Em função dessas mesmas condições de existência a luta pela sobrevivência se organizará em associações mutualistas e beneficentes. Porém, interessa aqui destacar que, da mesma forma como os trabalhadores associaram-se para autoproteção, também o fizeram para se educarem num contexto em que, nem a assistência, nem a educação eram considerados direitos sociais. Cabe considerar ainda, que a educação também era considerada por aqueles sujeitos como condição de existência e instrumento na luta pela sobrevivência.

Nesse sentido o "fazer-se da classe trabalhadora" (THOMPSON, 2004) tem na educação um de seus aspectos constituintes. O presente texto toma este aspecto como questão central, mas não necessariamente a educação como um projeto exterior, imposto pelas elites às classes trabalhadoras, ainda que as elites possuíssem projetos para educá-las e estes fossem, de fato, hegemônicos. A hegemonia, entretanto, não apaga práticas alternativas no interior da própria classe, nas quais procuro o que venho chamando de um "educar-se da classe trabalhadora" seja nas suas organizações, pela imprensa, por meio da própria forma escolar e na luta reivindicativa por educação formal.

A primeira parte deste capítulo empreende a caracterização das associações pesquisadas. Durante este esforço, foi possível perceber a mudança de orientação no movimento associativo de trabalhadores entre meados do século XIX e início do século XX. As leituras de estatutos, relatórios, periódicos e outras publicações, além da própria historiografia que aborda a temática permitiram observar a passagem de uma realidade marcada pelo paternalismo (tanto dentro das associações quanto nas suas relações com o Estado) para uma realidade em que predominava o classismo. Onde antes a negociação era o mecanismo preferencialmente usado para efetivar interesses, instala-se mais abertamente o conflito, abrindo espaço para mais afirmação de direitos e menos deferência e compromisso com a retribuição das dádivas.

Ciente da imersão num contexto histórico de transformações mais amplas nas relações sociais e políticas, procuro demonstrar que as novas formas assumidas pelas organizações operárias não foram, simplesmente, a aplicação de alguma teoria ou modelo pronto àquela realidade, nem sequer, consequência automática das transformações sociais e políticas gerais. A transformação 
notada no caráter das associações de trabalhadores foi algo aprendido na experiência das lutas cotidianas. Da mesma forma que Thompson (2004) afirma ter sido a cultura radical elaborada entre a experiência e a teorização que vieram a constituir uma consciência de classe na Inglaterra entre fins do século XVIII e as três primeiras décadas do século XIX, podemos arriscar dizer que a cultura mobilizada pelas classes trabalhadora nas grandes greves do início do século XX no Brasil foi elaborada entre experiência e teorização no seu processo de organização desde as últimas décadas do século XIX. As teorias como o anarquismo, socialismo e comunismo "trazidas de fora" precisaram, no mínimo, encontrar aqui um terreno fértil.

\section{1- Caracterização das organizações quanto as fontes}

Trabalho com um universo de cinquenta e duas organizações (apresentadas em tabela a seguir) selecionadas entre centenas existentes no período de atuação que vai de 1835 a 1912 : primeira e última data de fundação no universo abordado. A escolha foi guiada basicamente por quatro critérios: a presença de sujeitos de classes trabalhadoras; o período entre fins do século XIX e início do século XX, no qual se ampliam os debates e implementação de iniciativas de educação para as classes populares ${ }^{43}$; o desenvolvimento de práticas educativas no interior da associação; por fim, a disponibilidade de fontes.

Tabela 1: Nomes das associações e respectiva documentação consultada ${ }^{44}$

\begin{tabular}{|l|l|l|l|}
\hline Nome & Data de fundação & Localização da sede & Tipo de fonte \\
\hline $\begin{array}{l}\text { 1- Associação Bahiana } \\
\text { de Beneficência }\end{array}$ & 4 de julho de 1880 & Município da corte & $\begin{array}{l}\text { Parecer do Conselho de } \\
\text { Estado (1880); } \\
\text { Assistência Pública e } \\
\text { Privada no Rio de } \\
\text { Janeiro }\end{array}$ \\
\hline $\begin{array}{l}\text { 2- Associação } \\
\text { Beneficente do Corpo }\end{array}$ & $\begin{array}{l}29 \text { de dezembro de } \\
1907\end{array}$ & Distrito federal & $\begin{array}{l}\text { Assistência Pública e } \\
\text { Privada no Rio de }\end{array}$ \\
\hline
\end{tabular}

43 Este marco é coerente com a mudança no caráter das organizações de trabalhadores percebida por Batalha (2004) que indica como sinal dos tempos "o sindicalismo a partir de 1917 já não era o das associações de ofício que contavam com um número reduzido de membros, mas o de sindicatos industriais que reuniam milhares de operários". Todas as associações aqui estudadas têm observados sua fundação e período de atuação anteriores a 1917.

44 É necessária uma ressalva quanto ao amplo universo de associações exposto na Tabela 1. Não foi possível constituir séries documentais homogêneas acerca de cada uma delas. Dessa forma, em alguns casos a serem explicitados mais a frente, trabalhamos com estatutos e relatórios, em outros apenas com o estatuto, ou com o relatório e notícias complementares presentes em Assistência Pública e Privada no Rio de Janeiro e no Dicionário do Movimento Operário (BATALHA, 2009). Apenas algumas das organizações presentes na tabela forneceram elementos privilegiados para a constituição do corpo deste capítulo. 


\begin{tabular}{|c|c|c|c|}
\hline $\begin{array}{l}\text { de Oficiais Inferiores } \\
\text { da Armada }\end{array}$ & & & $\begin{array}{l}\text { Janeiro (fundação em } \\
\text { 1907) }\end{array}$ \\
\hline $\begin{array}{l}\text { 3- Associação } \\
\text { Beneficente } \\
\text { Homenagem a } \\
\text { Bithencourt da Silva }\end{array}$ & 8 de maio de 1882 & Município da corte & $\begin{array}{l}\text { Assistência Pública e } \\
\text { Privada no Rio de } \\
\text { Janeiro } \\
\text { (fundação em 1855) }\end{array}$ \\
\hline $\begin{array}{l}\text { 4- Associação de } \\
\text { Classe União dos } \\
\text { Pedreiros }\end{array}$ & $\begin{array}{l}\text { Aproximadamente } \\
1903\end{array}$ & Distrito federal & $\begin{array}{l}\text { Dicionário do } \\
\text { Movimento Operário } \\
\text { (estatutos em 1904) }\end{array}$ \\
\hline $\begin{array}{l}\text { 5- Associação de } \\
\text { Marinheiros e } \\
\text { Remadores }\end{array}$ & 23 de outubro de 1904 & Distrito federal & $\begin{array}{l}\text { Assistência Pública e } \\
\text { Privada no Rio de } \\
\text { Janeiro (fundação em } \\
\text { 1904) }\end{array}$ \\
\hline $\begin{array}{l}\text { 6- Associação de } \\
\text { Resistência dos } \\
\text { Cocheiros Carroceiros } \\
\text { e Classes Anexas }\end{array}$ & 23 de setembro de 1906 & Distrito federal & $\begin{array}{l}\text { Dicionário do } \\
\text { Movimento Operário } \\
\text { (estatutos em 1893) }\end{array}$ \\
\hline $\begin{array}{l}\text { 7- Associação de } \\
\text { Socorro Familiar } \\
\text { Homenagem a Serpa } \\
\text { Pinto }\end{array}$ & $?$ & Município da corte & $\begin{array}{l}\text { Parecer do Conselho de } \\
\text { Estado (1882) }\end{array}$ \\
\hline $\begin{array}{l}\text { 8- Associação de } \\
\text { Socorros Mútuos "Liga } \\
\text { Operária" }\end{array}$ & 1870 & Município da corte & $\begin{array}{l}\text { Dicionário do } \\
\text { Movimento Operário } \\
\text { (parecer do conselho de } \\
\text { estado e almanak } \\
\text { Laemert em 1870) }\end{array}$ \\
\hline $\begin{array}{l}\text { 9- Associação dos } \\
\text { Empregados do } \\
\text { Comércio no Rio de } \\
\text { Janeiro }\end{array}$ & 7 de março de 1880 & Município da corte & $\begin{array}{l}\text { Dicionário do } \\
\text { Movimento Operário } \\
\text { (parecer do conselho de } \\
\text { estado e almanak } \\
\text { Laemert em 1870); } \\
\text { Assistência Pública e } \\
\text { Privada no Rio de } \\
\text { Janeiro }\end{array}$ \\
\hline $\begin{array}{l}\text { 10- Associação dos } \\
\text { Funcionários Públicos } \\
\text { Civis }\end{array}$ & 14 de julho de 1904 & Distrito federal & $\begin{array}{l}\text { Assistência Pública e } \\
\text { Privada no Rio de } \\
\text { Janeiro }\end{array}$ \\
\hline $\begin{array}{l}\text { 11- Associação Geral } \\
\text { de Auxílios Mútuos da } \\
\text { Estrada de Ferro } \\
\text { Central do Brasil }\end{array}$ & 19 de março de 1884 & Município da corte & $\begin{array}{l}\text { Assistência Pública e } \\
\text { Privada no Rio de } \\
\text { Janeiro }\end{array}$ \\
\hline $\begin{array}{l}\text { 12- Associação } \\
\text { Nacional dos Artistas } \\
\text { Brasileiros Trabalho, } \\
\text { União e Moralidade }\end{array}$ & 7 de setembro de 1855 & Município da corte & $\begin{array}{l}\text { Assistência Pública e } \\
\text { Privada no Rio de } \\
\text { Janeiro }\end{array}$ \\
\hline $\begin{array}{l}\text { 13- Associação } \\
\text { Tipográfica Fluminense }\end{array}$ & 1853 & $\begin{array}{l}\text { Município da corte e } \\
\text { província do Rio de }\end{array}$ & Estatutos (1853) \\
\hline
\end{tabular}




\begin{tabular}{|c|c|c|c|}
\hline & & Janeiro & \\
\hline $\begin{array}{l}\text { 14- Centro dos } \\
\text { Operários Marmoristas }\end{array}$ & 19 de julho de 1903 & Distrito Federal & $\begin{array}{l}\text { Dicionário do } \\
\text { Movimento Operário } \\
\text { (ofício de títulos e } \\
\text { documentos e jornais } \\
\text { operários em 1903) }\end{array}$ \\
\hline $\begin{array}{l}\text { 15- Clube dos Libertos } \\
\text { Contra a Escravidão }\end{array}$ & 16 de junho de 1882 & Niterói & Estatutos (1882) \\
\hline $\begin{array}{l}\text { 16- Congresso de } \\
\text { Beneficência e } \\
\text { Instrução (antigo } \\
\text { Operário de } \\
\text { Beneficência) } \\
\end{array}$ & 29 de abril de 1883 & Município da corte & $\begin{array}{l}\text { Estatutos (1889); } \\
\text { Requisição ao } \\
\text { Imperador (1883) }\end{array}$ \\
\hline $\begin{array}{l}\text { 17- Corpo Coletivo } \\
\text { União Operária }\end{array}$ & 05 de março de 1880 & Município da corte & $\begin{array}{l}\text { Programa da Seção } \\
\text { Solene Comemorativa } \\
\text { da Independência do } \\
\text { Império (1885) }\end{array}$ \\
\hline $\begin{array}{l}\text { 18- Imperial Sociedade } \\
\text { Auxiliadora das Artes } \\
\text { Mecânicas Liberais e } \\
\text { Beneficente }^{45}\end{array}$ & 25 de março de 1835 & Município da corte & $\begin{array}{l}\text { Relatório (1864; 1876); } \\
\text { Assistência Pública e } \\
\text { Privada no Rio de } \\
\text { Janeiro }\end{array}$ \\
\hline $\begin{array}{l}\text { 19- Imperial Sociedade } \\
\text { União Beneficente dos } \\
\text { Guardas Nacionais }\end{array}$ & 1860 & Município da corte & Estatutos (1860) \\
\hline $\begin{array}{l}\text { 20- Liga Federal dos } \\
\text { Empregados em } \\
\text { Padaria no Rio de } \\
\text { Janeiro }\end{array}$ & 24 de agosto de 1902 & Distrito federal & $\begin{array}{l}\text { Assistência Pública e } \\
\text { Privada no Rio de } \\
\text { Janeiro } \\
\text { (fundação em 1902) }\end{array}$ \\
\hline 21- Partido Operário & 11 de maio de 1890 & Distrito federal & $\begin{array}{l}\text { Dicionário do } \\
\text { Movimento Operário } \\
\text { (Carone e Pádua, 1890) }\end{array}$ \\
\hline $\begin{array}{l}\text { 22- Partido Operário do } \\
\text { Brasil }\end{array}$ & Agosto de 1892 & Distrito federal & $\begin{array}{l}\text { Dicionário do } \\
\text { Movimento Operário } \\
\text { (Droz, Pinheiro e Hall, } \\
\text { Gomes e Carone, 1892- } \\
1893 \text { ) }\end{array}$ \\
\hline $\begin{array}{l}\text { 23- Partido Operário } \\
\text { Independente }\end{array}$ & 1905 & Distrito federal & $\begin{array}{l}\text { Dicionário do } \\
\text { Movimento Operário } \\
\text { (Arquivo Nacional, }\end{array}$ \\
\hline
\end{tabular}

45 Surgiu de uma reunião de artistas como Sociedade Auxiliadora das Artes e Beneficente dos Sócios e Suas Famílias, associação que também consta nesta relação. O Dicionário do Movimento Operário (BATALHA, 2009) data a aprovação dos estatutos desta primeira associação de julho de 1837 , entretanto, os estatutos localizados na Biblioteca Nacional tem edição em 1835 e afirmam terem sido sancionados em 1833. Ainda segundo Batalha, em 1840 a sociedade adota o nome de Auxiliadora das Artes Mecânicas e Liberais, como resultado da fusão com a Sociedade Mecânica e em 1848 recebe o título de Imperial. "Em maio de 1877, época em que surgiram divergências entre os sócios em torno de uma reforma dos estatutos, sua composição original foi inteiramente alterada, admitindo comerciantes, capitalistas e até negreiros" (BATALHA, 2009). 


\begin{tabular}{|c|c|c|c|}
\hline & & & 1905-1906) \\
\hline $\begin{array}{l}\text { 24- Partido Operário } \\
\text { Socialista }\end{array}$ & 25 de outubro de 1908 & Distrito federal & $\begin{array}{l}\text { Dicionário do } \\
\text { Movimento Operário } \\
\text { (Carone, 1895) }\end{array}$ \\
\hline $\begin{array}{l}\text { 25- Partido Socialista } \\
\text { Brasileiro }\end{array}$ & Dezembro de 1906 & Distrito federal & $\begin{array}{l}\text { Dicionário do } \\
\text { Movimento Operário } \\
\text { (jornais operários, } \\
1906 \text { ) }\end{array}$ \\
\hline $\begin{array}{l}\text { 26- Sociedade Amparo } \\
\text { Operário }\end{array}$ & 1878 & Niterói & $\begin{array}{l}\text { Reforma de Estatutos } \\
(1880) ; \text { Estatutos } \\
(1878)\end{array}$ \\
\hline $\begin{array}{l}\text { 27- Sociedade } \\
\text { Animadora da } \\
\text { Corporação dos } \\
\text { Ourives }\end{array}$ & 1 de abril de 1838 & Município da corte & $\begin{array}{l}\text { Dicionário do } \\
\text { Movimento Operário } \\
\text { (conselho de Estado, } \\
\text { Almanak Laemert, } \\
\text { Imprensa, 1838) }\end{array}$ \\
\hline $\begin{array}{l}\text { 28- Sociedade } \\
\text { Auxiliadora das Artes e } \\
\text { Ofícios e Beneficente } \\
\text { dos Sócios e Suas } \\
\text { Famílias }\end{array}$ & 1833 & Município da corte & Estatutos (1833) \\
\hline $\begin{array}{l}\text { 29- Sociedade Bem } \\
\text { Estar dos Caixeiros no } \\
\text { Rio de Janeiro }\end{array}$ & 1836 & Município da corte & Estatutos (1835) \\
\hline $\begin{array}{l}\text { 30- Sociedade } \\
\text { Beneficente dos } \\
\text { Artistas em São } \\
\text { Cristóvão }\end{array}$ & 21 de agosto de 1875 & Município da corte & $\begin{array}{l}\text { Parecer do Conselho de } \\
\text { Estado (1882); } \\
\text { Assistência Pública e } \\
\text { Privada no Rio de } \\
\text { Janeiro }\end{array}$ \\
\hline $\begin{array}{l}\text { 31- Sociedade } \\
\text { Beneficente Filhos da } \\
\text { Luz }\end{array}$ & 30 de junho de 1880 & $?$ & $\begin{array}{l}\text { Parecer do Conselho de } \\
\text { Estado (1880) }\end{array}$ \\
\hline $\begin{array}{l}\text { 32- Sociedade } \\
\text { Beneficente Litográfica }\end{array}$ & $\begin{array}{l}24 \text { de novembro de } \\
1901\end{array}$ & Município da corte & $\begin{array}{l}\text { Assistência Pública e } \\
\text { Privada no Rio de } \\
\text { Janeiro }\end{array}$ \\
\hline $\begin{array}{l}\text { 33- Sociedade } \\
\text { Beneficente Mútuo } \\
\text { Progresso do Engenho } \\
\text { de Dentro }\end{array}$ & 8 de junho de 1875 & Município da corte & $\begin{array}{l}\text { Assistência Pública e } \\
\text { Privada no Rio de } \\
\text { Janeiro }\end{array}$ \\
\hline $\begin{array}{l}\text { 34- Sociedade } \\
\text { Concórdia Beneficente } \\
28 \text { de Abril }\end{array}$ & 1875 & Niterói & $\begin{array}{l}\text { Estatutos (1875); } \\
\text { Reforma de Estatutos } \\
(1879) ; \text { Pedido de } \\
\text { auxílio sobre } \\
\text { divergência interna } \\
(1877)\end{array}$ \\
\hline
\end{tabular}




\begin{tabular}{|c|c|c|c|}
\hline $\begin{array}{l}\text { 35- Sociedade } \\
\text { Cosmopolita Protetora } \\
\text { dos Empregados de } \\
\text { Padaria }\end{array}$ & $\begin{array}{l}30 \text { de novembro de } \\
1898\end{array}$ & Distrito federal & $\begin{array}{l}\text { Dicionário do } \\
\text { Movimento Operário } \\
\text { (Almanak Laemert e } \\
\text { Duarte, 1898) }\end{array}$ \\
\hline $\begin{array}{l}\text { 36- Sociedade de } \\
\text { Beneficência dos } \\
\text { Artistas da Construção } \\
\text { Naval }\end{array}$ & 30 de maio de 1858 & Município da corte & $\begin{array}{l}\text { Parecer do conselho de } \\
\text { Estado (1879); } \\
\text { Assistência Pública e } \\
\text { Privada no Rio de } \\
\text { Janeiro }\end{array}$ \\
\hline $\begin{array}{l}\text { 37- Sociedade de } \\
\text { Resistência dos } \\
\text { Trabalhadores em } \\
\text { Trapiches e Café }\end{array}$ & 3 de abril de 1905 & Município da corte & $\begin{array}{l}\text { Assistência Pública e } \\
\text { Privada no Rio de } \\
\text { Janeiro } \\
\text { (fundação em 1905) }\end{array}$ \\
\hline $\begin{array}{l}\text { 38- Sociedade de } \\
\text { Socorros Mútuos } \\
\text { Marques de Pombal }\end{array}$ & 29 de junho de 1881 & Município da corte & $\begin{array}{l}\text { Parecer do Conselho de } \\
\text { Estado (1882) }\end{array}$ \\
\hline $\begin{array}{l}\text { 39- Sociedade de } \\
\text { Socorros Mútuos } \\
\text { Protetora dos Artistas } \\
\text { Sapateiros e Classes } \\
\text { Correlativas }\end{array}$ & 10 de maio de 1875 & Município da corte & Relatório (1885-1886) \\
\hline $\begin{array}{l}\text { 40- Sociedade de } \\
\text { Socorros Mútuos União } \\
\text { Familiar e Perfeita } \\
\text { Amizade }\end{array}$ & 1 de janeiro de 1873 & Município da corte & $\begin{array}{l}\text { Relatório (1886); } \\
\text { Assistência Pública e } \\
\text { Privada no Rio de } \\
\text { Janeiro }\end{array}$ \\
\hline $\begin{array}{l}\text { 41- Sociedade dos } \\
\text { Carpinteiros e Artes } \\
\text { Correlativas }\end{array}$ & 27 de maio de 1903 & Município da corte & $\begin{array}{l}\text { Dicionário do } \\
\text { Movimento Operário }\end{array}$ \\
\hline $\begin{array}{l}\text { 42- Sociedade } \\
\text { Industrial de } \\
\text { Beneficência }\end{array}$ & $?$ & $?$ & $\begin{array}{l}\text { Pareceres do Conselho } \\
\text { de Estado (1863) }\end{array}$ \\
\hline $\begin{array}{l}\text { 43- Sociedade Operária } \\
\text { do Jardim Botânico }\end{array}$ & 1903 & Distrito federal & $\begin{array}{l}\text { Dicionário do } \\
\text { Movimento Operário } \\
\text { (imprensa e Azevedo, } \\
\text { 1903) }\end{array}$ \\
\hline $\begin{array}{l}\text { 44- Sociedade Protetora } \\
\text { dos Empregados } \\
\text { Públicos }\end{array}$ & 1906 & Todo o Império & Estatutos (1876) \\
\hline $\begin{array}{l}\text { 45- Sociedade Socorros } \\
\text { Mútuos Montepio dos } \\
\text { Conservadores }\end{array}$ & 1881 & Barra do Piraí & $\begin{array}{l}\text { Projeto de Estatutos } \\
(1881)\end{array}$ \\
\hline $\begin{array}{l}\text { 46- Sociedade União } \\
\text { Beneficente dos } \\
\text { Cocheiros }\end{array}$ & 17 de abril de 1881 & Município da corte & $\begin{array}{l}\text { Parecer do Conselho de } \\
\text { Estado (1872) }\end{array}$ \\
\hline $\begin{array}{l}\text { 47- Sociedade União } \\
\text { dos Foguistas }\end{array}$ & 26 de setembro de 1903 & Distrito federal & $\begin{array}{l}\text { Assistência Pública e } \\
\text { Privada no Rio de }\end{array}$ \\
\hline
\end{tabular}




\begin{tabular}{|l|l|l|l|} 
& & & Janeiro \\
\hline $\begin{array}{l}\text { 48- União Beneficente } \\
29 \text { de Julho }\end{array}$ & 1 de novembro de 1860 & Município da corte & $\begin{array}{l}\text { Estatuto (1861); Parecer } \\
\text { do Conselho de Estado } \\
(1879)\end{array}$ \\
\hline $\begin{array}{l}\text { 49- União Beneficente } \\
\text { Niteroiense }\end{array}$ & $?$ & Niterói & $\begin{array}{l}\text { Relatório (1886); } \\
\text { Requerimento à } \\
\text { Presidência da } \\
\text { Província para extração } \\
\text { de loteria }\end{array}$ \\
\hline $\begin{array}{l}50-\text { União dos } \\
\text { Operários das Pedreiras }\end{array}$ & 1901 & Distrito federal & $\begin{array}{l}\text { Dicionário do } \\
\text { Movimento Operário } \\
\text { (almanak Laemert, } \\
\text { jornais operários em } \\
1901)\end{array}$ \\
\hline $\begin{array}{l}51-\text { União dos } \\
\text { Operários Estivadores }\end{array}$ & 13 de setembro de 1903 & Distrito federal & $\begin{array}{l}\text { Dicionário do } \\
\text { Movimento Operário } \\
\text { (Almanak Laemert, } \\
\text { imprensa, 1 Oofício de } \\
\text { títulos e documentos, } \\
\text { 1903); Assistência } \\
\text { Pública e Privada no } \\
\text { Rio de Janeiro }\end{array}$ \\
\hline $\begin{array}{l}52-\text { União Protetora do } \\
\text { Comércio Volante }\end{array}$ & & $\begin{array}{l}\text { Assistência Pública e } \\
\text { Privada no Rio de } \\
\text { Janeiro } \\
\text { (fundação em 1912) }\end{array}$ \\
\hline
\end{tabular}

A maioria das organizações teve sua fundação durante as três últimas décadas do século XIX e entre os títulos a elas atribuídos temos: associações, centros, clube, congresso, corpo coletivo, imperiais sociedades, ligas, partidos, sociedades beneficentes, sociedades de socorros ou auxílios mútuos, sociedades de resistência, uniões. O termo associação percorre todo período analisado. O termo imperial sociedade, como ele mesmo diz, restringe-se ao período imperial, denota, porém, uma duração mais ou menos longa por serem sociedades mais estáveis. Os termos: ligas, centros e partidos concentram-se nos últimos anos do século XIX e seguem pelo XX. Já as sociedades de beneficência e auxílio mútuo concentram-se na segunda metade do XIX, enquanto o título união é usado prioritariamente a partir do século XX.

As associações apresentam, desde seus títulos, o pertencimento de seus membros: operários, artistas, especialistas em um ou outro ofício. Algumas explicitam seus fins de auxílio e beneficência sem referirem-se a sujeitos, mas todas elas agregavam trabalhadores, cujo traço distintivo bem definiu Savage (2004): uma "insegurança estrutural" derivada da retirada dos seus meios de subsistência. Quanto ao seu local/sede, observamos a proeminência do município da corte/distrito 
federal, com algumas presentes em Niterói, ou seja, os principais centros urbanos da província (no caso da corte, do próprio Império). Espaços de maior concentração de trabalhadores livres assalariados, expostos a maior circulação de ideias nacionais e/ou estrangeiras, em contato com maiores recursos materiais e técnicos. Mesmo assim, algumas dessas sociedades admitiam, socorriam e organizavam trabalhadores de outras partes da província.

As mudanças nas formas de nomear as organizações expressam transformações no caráter deste movimento associativo: de assistência e proteção na esfera da reprodução das condições de vida para reivindicação na esfera da produção. Essas fronteiras não estavam, porém, bem delimitadas no período estudado. Em seu trabalho sobre o mutualismo como estratégia popular de sobrevivência, Cláudia Viscardi (2009) nos mostra o quanto a pobreza era uma realidade constante nos meios trabalhadores e como as formas de enfrentá-la coletivamente foram importantes no processo de formação das classes trabalhadoras. Ou seja, a formação da classe não se dá, apenas, nos espaços formais de trabalho, e os tão constantes questionamentos sobre os limites entre classes populares e classes trabalhadoras podem não encontrar amparo na realidade histórica do Rio de Janeiro oitocentista.

Este era um momento em que se misturavam recursos de superação da pobreza, por um lado, os apelos por proteção a alguém que dispusesse de bens a serem doados, em geral: Igreja, Estado, cidadão benemérito, coronel, e "variações que se encaixam bem no conceito de paternalismo" (VISCARDI, 2009, p. 293). Por outro lado, havia a ajuda mútua que estabelecia uma relação de reciprocidade entre os sujeitos, enquanto a primeira estratégia estabelecia uma relação de poder de quem doa sobre quem recebe.

Interessa destacar, ainda, nas concepções da autora, a importância atribuída à educação como estratégia de superação da pobreza, elemento de troca em relações paternalistas, ou por outro lado, elemento de coesão nas relações mutualistas. Em todo caso, parte relevante da experiência social dos sujeitos ditos pobres - aqueles chamados de classes populares, em geral e classes trabalhadoras, em particular. A presente tese corrobora e procura demonstrar esse papel histórico cumprido pela educação popular.

Em que pese, muitas vezes, as diferenças de acesso à educação (especialmente as primeiras letras) participarem na distinção interna ao universo dos sujeitos mais ou menos marginalizados, pelo fato da instrução representar um "capital simbólico" determinante na obtenção de empregos formais e na própria organização coletiva, Viscardi (2009) defende que a composição das mutuais não se deu por uma "aristocracia operária". Ela não descarta sua existência, nem a presença de "sujeitos bem aquinhoados" no quadro dessas organizações, porém seria

(...) inegável que o movimento associativo mutualista foi composto, sobretudo, por trabalhadores - assalariados ou não - que por não serem 
ricos, precisavam garantir a sua sobrevivência e a de seus familiares em momentos de infortúnio. Dessa forma, as mutuais recrutaram seus sócios preferencialmente entre os trabalhadores humildes, que não fossem totalmente destituídos ou marginalizados, mas que delas necessitassem, por não disporem nem da proteção do Estado nem de riquezas acumuladas. Na ausência das mutuais, só lhes restaria a caridade alheia (VISCARIDI, 2009, p. 294).

As reflexões da autora, ao partir das estratégias dos próprios pobres na luta por sua sobrevivência em suas próprias redes de solidariedade, tão pouco estudadas, permitiram inferir algo que emparelha-se com a afirmação da presente tese sobre as lutas das classes populares por educação. As associações de auxílio mútuo, no universo de suas ambiguidades, teriam contribuído para a formação de uma "cultura de respeitabilidade" (VISCARDI, 2009, p. 312) entre os trabalhadores, que fazia dos benefícios recebidos, não favores, e sim direitos. É o que aqui defendemos - a passagem da educação popular de dádiva a direito se deu por uma ação ativa formal ou informalmente organizada das próprias classes populares ${ }^{46}$.

As fontes utilizadas para o desenvolvimento deste capítulo, como consta na Tabela 1, foram: estatutos e relatórios das associações; pareceres do Conselho de Estado sobre aprovação ou não de estatutos e suas reformas; uma volumosa publicação estatística sobre Assistência Pública e Privada no Rio de Janeiro; e verbetes do Dicionário do Movimento Operário no Rio de Janeiro editado por Cláudio Batalha $(2009)^{47}$.

Em função da dificuldade de obter séries documentais expressivas que possibilitassem o aprofundamento da análise em uma ou algumas associações, embora umas estejam mais documentadas que outras, e pelo fato da investigação não objetivar as entidades em si mesmas, mas o fenômeno educativo por elas protagonizado, optei pela abordagem horizontal de temáticas que perpassam o conjunto da documentação compulsada. São elas: $1^{\circ}$ - os contornos da classe trabalhadora entre às relações paternalistas e conflituosas; $2^{\circ}$ - as normas disciplinares e penalidades definidas pelas associações; $3^{\circ}$ - as práticas democráticas perpetradas por elas; $4^{\circ}$ - a diversidade e estratificação no interior das associações e entre elas; $5^{\circ}$ - a existência de uma cultura mutualista no período estudado.

Encerrando o capítulo apresento o foco principal deste trabalho: os indícios das práticas formativas/educativas desenvolvidas pelas associações, com ou sem o intuito de formação ou educação sistemática. Considero haver uma formação intelectual em sentido amplo com ênfase no

46 Agradeço à Professora Dr $^{\mathrm{a}}$ Irma Rizzini pela indicação do trabalho de Viscardi, já nos momentos finais da escrita da tese.

47 Cabe ressaltar que a obra de Batalha, fonte secundária, foi utilizada em caráter complementar e para cotejar informações sobre as associações de trabalhadores. 
“aprendizado da política". Também é dado destaque às relações dessas instituições e sujeitos com o mundo da leitura e escrita. Tipo de formação intelectual e relação com as letras que se ligava estreitamente à outra importante esfera formativa da classe - a imprensa operária, abordada no capítulo três.

Diante da diversidade de experiências pontuais dessas organizações, o que haveria em comum, o que faria delas, sujeitos de seu tempo? Por que teriam existido daquela maneira, naquele momento? Uma primeira resposta seria lembrar que elas constituem uma opção de pesquisa. A intervenção de um historiador sobre a realidade passada às erige como objeto, fazendo-lhes retornar à vida, ou dando-lhes vida em outros termos. Segundo Certeau, a crítica ao positivismo e sua principal característica - o cientificismo - deixou clara a inexistência de um objeto independente da ação do cientista, pronto para ser apreendido tal como ele é. Mostrou-se que toda interpretação histórica depende de um sistema de referência. (...) Agora sabemos a lição na ponta da língua. Os “fatos históricos" já são construídos pela introdução de um sentido na objetividade (CERTEAU, 1982, p. 67).

Sigamos então, tentando introduzir o dito sentido na objetividade encarnada pelas fontes levantadas. Iniciemos com a série mais extensa e regular: a dos estatutos. É possível notar uma estrutura mais ou menos comum seguida por eles. Esta mesma era garantida pelas normas legais a que estavam submetidos. Lacerda (2008) observa que no ano de 1860 é promulgada a lei 1.083, posteriormente modificada pelos decretos 2.686 e 2.711 que tinham por objetivo estabelecer procedimentos por meio dos quais seriam reguladas quaisquer organizações no Império.

Após solicitar a autorização junto ao chefe de polícia local para realizar as reuniões, os interessados em criar as associações deveriam promover os encontros necessários para confeccionar os estatutos e fundar sociedades, grêmios, clubes ou irmandades. Posteriormente, as atas das sessões fundadoras e os estatutos deveriam ser enviados à Seção dos Negócios do Império do Conselho de Estado, a fim de serem submetidas à avaliação em processo que orientava a criação e o funcionamento das chamadas "sociedades", inclusive as que foram criadas anteriormente ao estatuto da lei. Entretanto, o procedimento burocrático iniciado em 1860 teve fim com a promulgação da lei 3.150 de novembro de 1882. (LACERDA, 2008, p.3)

Ronaldo Pereira ilustra a fundação da sociedade de marceneiros e carpinteiros da corte. A primeira sessão ocorreu a 17 de março de 1875, reunindo na Rua do Príncipe $\mathrm{n}^{\circ}$ 37, quarenta pessoas de diferentes classes.

A segunda sessão ocorreu no dia 29 de março de 1875 e contou com a presença de 75 pessoas. Uma terceira, realizada em 10 de setembro, registrou 157 sócios inscritos. Nesta ocasião elaboraram uma lista em que cada membro presente deixou sua assinatura e endereço. Nota-se que, entre 
os 157 membros, havia 58 sócios que moravam na Rua do Príncipe. Destes, 16 moravam na casa que servia como sede provisória da associação, no 37, e outros 26 no 42. Pode-se supor que tratava-se de uma habitação coletiva uma casa de cômodos que abrigava um grande número de marceneiros e carpinteiros que, além de morarem juntos, sentiram-se dispostos a defender seus interesses coletivos de forma organizada (PEREIRA, 1999, p. 200).

Em linhas gerais, as temáticas tratadas nos estatutos eram as seguintes: 1- objetivos ou fins da Sociedade; 2- organização (quem a compõe, a quem é vedada a participação); 3- deveres da Sociedade para com seus sócios ou direitos dos sócios; 4- a assembleia geral (sua função, como é convocada, procedimentos); 5- eleições (como ocorrem, critérios para votar e ser votado, os cargos eletivos); 6- administração (conselhos, diretorias, comissões: suas atribuições); 7- admissão dos sócios (critérios de admissão, procedimentos); 8- deveres dos sócios (bem como os critérios disciplinares e as penalidades para quem deles se desviasse); 9- fundos da sociedade (como são constituídos, sua aplicação); 10- titulação e classificação dos sócios (efetivos, beneméritos, benfeitores, honorários); 11- em alguns casos havia tópico específico para tratar do tesoureiro, em outros, tópico específico para tratar das beneficências; 12-por fim as disposições gerais.

A configuração desses temas nos diferentes estatutos podia variar, o fato é que abordavam questões semelhantes com alguns acréscimos, ausências ou diferenças de redação ${ }^{48}$. É, porém, importante estar atento para as ênfases e variações que, mesmo sutis, ajudam a compreender a especificidade de cada Sociedade. Já nos relatórios as práticas sociais são expostas mais "livremente". Eles são prestações de contas apresentadas em fins de gestão das diretorias, dão notícia do cumprimento das próprias prescrições dos estatutos, mas possuem um tom mais dinâmico, apontando acontecimentos, sugerindo desde as visões mundo de seus relatores até os conflitos no interior das Sociedades.

É importante ressaltar o caráter legislativo, formalizado e formalizador dos estatutos. Mesmo que não fossem levados ao pé da letra no cotidiano das relações entre os sócios e destes com o governo ou com outras entidades, são limites da ação e servem como organizadores. Podemos, porém, constatar disjunção entre norma e prática no relatório da Imperial Sociedade Auxiliadora das Artes Mecânicas e Liberais e Beneficente, do ano de 1876 quando prescreve eleições e participação dos sócios em mecanismos democráticos como a assembleia geral, ao passo

48 Tratando da institucionalização de uma iniciativa do movimento popular na contemporaneidade, o caso das creches comunitárias em Belo Horizonte, Minas Gerais, na década de oitenta do século XX, Biccas (1995) demonstra como a criação dos estatutos daquelas organizações adotavam como modelo o documento de outras entidades anteriormente formalizadas. Entre outros motivos para tal figurava fato dos sujeitos envolvidos na sua constituição terem pouco trânsito no universo da leitura e da escrita. A autora aponta como estas habilidades (ler e escrever) conferiam poder, naquele contexto, tendo sido um condicionante da participação da comunidade no processo de institucionalização da creche. 
que os diretores reclamam a falta de envolvimento daqueles e mesmo o baixo comparecimento às eleições. Problema momentâneo, derivado de conflitos internos ou situação crônica, serve para demonstrar que a inscrição do preceito na legislação social não é suficiente para que ele seja cumprido. Uma vez interessados em apreender a prática que estes estatutos orientam, devemos atentar para a diferença que elas estabelecem com as prescrições.

As práticas produzem-se como um ato, como uma operação, o que oferece dois tipos de problema ao historiador. O primeiro é a localização de registros. O segundo é a distinção metodológica entre práticas e prescrição/modelação de práticas. (...) Isso provoca como problema metodológico o estabelecimento de séries razoavelmente homogêneas e expressivas. E implica no cuidado em estabelecer mediações entre os níveis micro e macro da interpretação, de sorte a não formularem conclusões gerais a partir de dados, às vezes muito circunstanciados. (...) As prescrições desenham contornos do possível indiciando alguns dos repertórios disponíveis ao sujeito, mas não inibem que outros repertórios sejam ativados, construindo atos não previstos (VIDAL \& BICCAS, 2008, p. 24).

Nesse sentido, os estatutos como as leis em geral, são mediações que nos revelam sobre as relações internas e aquelas entre o governo imperial e as associações, em última análise sobre as tentativas de controle pelo governo de diferentes grupos e classes sociais. Porém, não devem ser vistos simplesmente como imposição vinda de cima, mas sim expressão de conflitos. Se pensarmos a partir da concepção de E. P. Thompson (1987) sobre "o domínio da lei”, talvez possamos vê-los não apenas como uma forma de controle à ação da sociedade civil, mas também como uma forma de viabilização, garantia mesmo da existência das associações, protegendo-as contra arbitrariedades desmedidas do Estado imperial, uma vez que a aprovação reconhecia sua legitimidade.

Ao diferenciar o "domínio da lei" da arbitrariedade institucionalizada aos moldes do absolutismo, Thompson trava um debate contra certo estruturalismo marxista reducionista para o qual a lei seria um instrumento da classe dominante, artefato da superestrutura em função de uma infraestrutura econômica para dominação de classe. Para ele a lei é mais que isso. De fato, uma de suas funções, como demonstra no estudo sobre "A lei negra" é o domínio classista e a mistificação. Mas ela representa também um conjunto de regras em relação com as regras sociais, e apresenta uma lógica interna, específica, técnica. Em muitos casos ela é acionada pelos dominados. E assim vemos artistas, operários e outros sujeitos pertencentes às classes populares formulando os estatutos de suas entidades e submetendo-os ao crivo do governo, instruídos nas formalidades técnicas, pleiteando, a aprovação estatal. Talvez a custa de algumas supressões de ideias e introdução de outras alheias às suas crenças. Certamente a lei mantém-se ao lado do mais forte, não há imparcialidade, sua principal virtualidade. 
Mas, se um excesso disso for verdade, as consequências serão francamente contraproducentes. A maioria dos homens tem um forte senso de justiça, pelo menos em relação a seus próprios interesses. Se é a lei manifestamente parcial e injusta, não vai mascarar nada, legitimar nada, contribuir em nada para a hegemonia de classe alguma. A condição prévia para a eficácia da lei em sua condição ideológica é de que mostre uma independência frente a manipulações flagrantes e pareça justa. Não conseguirá parecê-lo sem preservar sua lógica e critérios próprios de igualdade; na verdade às vezes sendo realmente justa. (THOMPSON, 1987, p. 354).

O processo de aprovação dos estatutos é uma forma privilegiada de captar as complexas relações Estado - sociedade. Um caso paradigmático é o da consulta de $1^{\circ}$ de março de 1882 ao Conselho de Estado, sobre a aprovação dos novos estatutos da Sociedade Beneficente dos Artistas em São Cristóvão. O primeiro ponto crítico dizia respeito à redação que "carecia de ser cuidadosamente revista e corrigida". Além dos aspectos formais, vemos o constante exercício de controle pelo conselho, buscando em cada brecha interferir nas questões internas da organização como mostra a proposta de alteração no parágrafo sexto do artigo décimo primeiro, que estabelecia a necessidade de se "dar recurso para o Governo Imperial da decisão da assembleia geral em caso de violência ou errada interpretação dos estatutos".

Tomando como base este e outros pareceres é possível ainda especular sobre certa intenção do governo imperial de esvaziar o poder das diretorias das associações, procurando em seus reparos proteger os sócios contra os abusos de autoridade. É o que vemos insinuado na proposta de alteração no fim do artigo dezenove: "que a exposição de fatos ocorridos no seio da Sociedade, ou a acusação da administração em geral, ou de qualquer membro por abuso de autoridade, excesso de poder ou infração dos estatutos não pode ser considerada como injúria”. Dentro dessa lógica, busca o reforço do poder da assembleia geral, quando propõe que tendo a administração o direito de nomear, suspender e demitir empregados, "impõe-se lhe a obrigação de na primeira reunião da assembleia geral sujeitar qualquer desses atos à aprovação". Da mesma forma, "onde se dá competência a administração para suspender qualquer beneficência, quando for indevida a sua continuação [deveria] acrescentar-se o seguinte: podendo recorrer para a assembleia geral o beneficiado que se julgar lesado".

Consta nesta consulta outra recomendação recorrente nos pareceres do conselho de Estado que era a ênfase nos crimes contra a honra ou contra a propriedade. Porém, a principal e mais intrigante objeção aos estatutos da Sociedade Beneficente dos Artistas em São Cristóvão diz respeito à restrição em se admitir indivíduos de cor preta e libertos de qualquer cor nos quadros da associação. De fato, o parecer é expedido num momento em que a luta abolicionista avançava e a escravidão já dava sinais de estar com seus dias contados, mas, seis anos antes da definitiva 
abolição fazem dele bastante contraditório para um Estado escravista. Ao mesmo tempo, podemos estranhar tal restrição, excluída a necessidade de cumprimento de critérios explícitos ou tácitos para aprovação governamental, por parte de uma associação de artistas na cidade do Rio de Janeiro, onde a maioria da população era negra e mais ainda entre as classes trabalhadoras. O que teria levado o conselho de Estado a apresentar uma posição aparentemente mais avançada que dos artistas em relação à questão escravista e de cor? De acordo com a interpretação de Chalhoub (2003) em seu estudo sobre associações de escravos e libertos cujos estatutos foram analisados pelo Conselho de Estado, o uso dos critérios restritivos de cor não seriam aceitos pelo Conselho porque este pretendia evitar o perigo de organizações próprias de negros. Ou seja, deveria haver um silenciamento da cor em prol de uma homogeneização com apagamento das causas específicas dos negros numa sociedade escravista. Outra via interpretativa é de que o parecerista estaria sendo legalista, uma vez que a constituição de 1824 teria reconhecido a cidadania aos libertos ${ }^{49}$. Seriam necessários mais dados sobre a Sociedade para se chegar a alguma conclusão, porém segue citado na íntegra o parecer:

Agora, quanto à objeção principal a que a Sessão se referiu no princípio desta consulta, versa ela sobre as disposições dos $\S \S 1^{\circ}$ e $2^{\circ}$ do artigo 5 que proíbe a admissão na sociedade dos indivíduos de cor preta e dos libertos de qualquer cor. Semelhantes disposições equivalem a exclusão sumamente odiosa de duas classes de cidadãos, fundando-se na distinção de cores contraria a índole do nosso sistema de governo e de tal modo injustificável que nem uma (sôrte?) substituindo elas, pode a Sessão aconselhar a aprovação do projeto. São tão óbvias as considerações que para isso se baseia, que não julga necessário expô-las, bastando-lhe pedir permissão para reportar-se às já expedidas em mais de uma antiga consulta contra disposições mais ou menos semelhantes de alguns compromissos de irmandades. - As Sociedades têm, sem dúvida, o direito pleníssimo de recusar a entrada em seu seio de qualquer indivíduo cuja admissão não ache conveniente, mas a exclusão de classes inteiras por motivos de natureza tão ? e ofensiva, tudo por fundamento a diferença de cor dos indivíduos, ou de sua liberdade, não pode jamais ser homologada pelo Governo Imperial pelo fato da aprovação de estatutos em que ela se ? e muito menos hoje, que os libertos estão por nossas leis habilitados para terem assento na representação nacional e ocuparem cargos públicos dos mais elevados. Se, portanto, a Sociedade insistir na conservação dos parágrafos citados não pode ser aprovado o projeto de estatutos de que se trata ainda que ela atenda todas as alterações acima indicadas. É este, senhor, o parecer da Sessão. V. M. Imperial, porém, resolverá com a costumada sabedoria o que for mais acertado.

Um dos motivos que dificulta esta interpretação diz respeito à própria natureza dos pareceres

49 Interpretação sugerida em debate com a Prof. Dra Alessandra Schueler. 
do Conselho de Estado como fonte. Ao menos naqueles acessados ao longo da pesquisa que originou esta tese, não encontramos anexados os estatutos, matérias dos pareceres, o que nos impossibilita o confronto entre o discurso da associação e o discurso do Conselho de Estado. Em geral, citam apenas os trechos a serem reformados, o que os descontextualizam para nós, leitores de outro século. Porém, toda fonte tem seus limites e cabe ao historiador saber lidar com eles.

Cabe um parêntese, antes de seguirmos com a análise da documentação, sobre a constituição do Conselho ao qual os estatutos das associações eram remetidos para que orientasse sua aprovação, alterações ou recusa. Segundo Maria Fernanda Vieira Martins, o Conselho era uma assembleia de notáveis com membros vitalícios que tinha como papel auxiliar o monarca em sua arbitragem de conflitos e conciliações de interesses, facilitando o exercício do poder ao intermediar as relações da coroa com diversos grupos políticos. Ligado diretamente ao poder central, atuou com ampla autonomia política e extensa ação reguladora e normativa. Seria a materialização do poder moderador. Foi instalado a partir da Lei número 234 de 23 de novembro de 1841 e atendia a consulta dos ministros e do próprio imperador. Os setenta e dois conselheiros incluíam ministros, senadores, fazendeiros, negociantes, capitalistas, militares e magistrados, descendentes de antigas famílias que comandavam o país desde o tempo colonial. Ao longo do segundo reinado, o Conselho junto com o senado resistiu como as sólidas instituições monárquicas e só foi suprimido com o fim da monarquia (MARTINS, 2006).

No caso da publicação intitulada Assistência Pública e Privada no Rio de Janeiro (Brasil). História e Estatísticas, produzida pelo governo do município do Rio de Janeiro, em 1922, em comemoração ao Centenário da Independência Nacional e editada pela Typographia do Anuário do Brasil, encontramos dois complicadores. O primeiro é o filtro do olhar de quem produziu as estatísticas. A obra foi mandada publicar sendo presidente da República o Dr. Epitácio da Silva Pessoa, o prefeito do Distrito Federal, Dr. Carlos César de Oliveira Sampaio e o diretor geral do Departamento de Assistência Pública o professor Dr. Luiz Barbosa. Em sua abertura, traz o despacho datado de 26 de junho de 1903 que determina a produção do levantamento estatístico. A “estatística geral de todos os estabelecimentos e instituições de caridade e de assistência, públicos ou privados" teria por objetivo servir de "base de toda e qualquer organização no sentido de se estabelecer a proteção sistematizada aos fracos e necessitados, logo que se torne oportuno providenciar a esse respeito". Ou seja, o Estado republicano preocupava-se em conhecer e controlar as organizações da sociedade civil em visível expansão desde a segunda metade do século XIX mais do que exatamente "providenciar a respeito" da "proteção aos fracos", pois até aquele momento, pelo menos, não havia considerado oportuno atuar nesse ramo de serviços de forma sistematizada. 
A obra que teve início em 1903, só seria concluída na gestão do prefeito Bento Ribeiro (1910-1914) que incumbiu o jornalista e escritor Ataulfo de Paiva de realizar um segundo levantamento geral de todos os estabelecimentos de assistência pública e privada da capital.

Para esse fim, Paiva organizou três tipos diferentes de questionários, que foram enviados às associações de auxílio mútuo, aos asilos e recolhimentos e a hospitais. Ademais, visitou quase todas as instituições sobre as quais obteve informações através do questionário. Foram recenseadas 624 instituições, que se encontravam em funcionamento entre os anos de $1912 \mathrm{e}$ 1920 no Rio de Janeiro. (...) Ataulfo de Paiva fez seu primeiro levantamento em 1912 e depois o completou com dados colhidos entre 1913 e 1920. Mas os critérios utilizados no momento de sistematização dos dados não foram uniformes (VISCARDI, 2009, p. 298, 299, 302).

Vemos que não pertencem à estatística apenas instituições de caridade e assistência e que os sujeitos nelas envolvidos, podem não ser "tão fracos assim". A publicação traz informações sobre inúmeras associações de trabalhadores que além de finalidades assistenciais possuíam finalidades educativas, reivindicativas e mesmo quando apenas beneficentes, não era possível apagar seu efeito de organização dos sujeitos nelas envolvidos. Entretanto, temos aí o segundo complicador, as informações sobre muitas dessas associações são extremamente resumidas, o que no leva a adotar este documento em caráter complementar, com intuito de preencher lacunas abertas na abordagem de estatutos, relatórios e pareceres do Conselho de Estado.

Da mesma forma o Dicionário do Movimento Operário (BATALHA, 2009), fonte secundária aqui utilizada, nos permite preencher algumas lacunas como as citadas anteriormente. Em sua introdução o organizador esclarece o formato da obra que se apresenta “(...) sob a forma de verbetes [com] informações bibliográficas sobre militantes e históricos de organizações da cidade do Rio de Janeiro, como capital (corte) do Império e, da República, como capital federal” (BATALHA, 2009, p. 9). A obra abarca cerca de um século, de 1830 a 1920, desde o surgimento das primeiras sociedades mutualistas na corte ao final da Primeira República. O período representa um recorte político-institucional, além de marcar as mudanças na forma de organização e na geração de militantes.

\section{2- Quem é a classe: paternalismo e conflito no universo das organizações de trabalhadores}

Ao empreendermos uma análise das organizações de trabalhadores como espaço educacional privilegiado, tendo por hipótese a relevância da educação na formação da classe trabalhadora no Rio de Janeiro, impõe-se uma questão mobilizadora de debates na historiografia do trabalho: é legítimo falar de classe trabalhadora no século XIX, imerso ainda num contexto escravista? 
Inicialmente é preciso assinalar que não interessa afirmar tal existência como forma de marcar qualquer posição ideológica, mas sim de pensar como o termo "classe" pode nos ajudar ou dificultar a compreensão da realidade de sujeitos e suas experiências no espaço e tempo propostos. O que mobiliza a presente análise é o que Thompson (2002) definiu, ao estudar o século XVIII inglês, como alguns "padrões de experiência".

De acordo com Batalha (1999) haveria dois motivos para não se considerar a existência de classe operária antes de 1888. Primeiro a presença do trabalho escravo que leva a questionar a existência do capitalismo no Brasil até esta data. E segundo, a concepção de que a classe operária é filha da indústria, logo só surgiria com o surto industrial a partir de 1880 . Em posição crítica a esta concepção, o autor procura mostrar elementos de continuidade e ruptura entre organizações operárias do XIX e do início do XX. É também Thompson, uma das referências para o próprio Batalha, que questiona a tese marxista da centralidade do operariado de fábrica na formação da classe trabalhadora ao remontar a tradição de luta dos artesãos. Os operários, longe de serem "filhos primogênitos da revolução industrial", tiveram nascimento tardio.

Muitas das suas ideias e formas de organização foram antecipadas por trabalhadores domésticos como os que trabalhavam com a lã em Norwick e em regiões do oeste. Ou os tecelões de aviamentos em Manchester. (...) Em muitas cidades o verdadeiro núcleo de onde o movimento trabalhista retirou suas ideias, organização e liderança era constituído por sapateiros, tecelões, seleiros e fabricantes de arreios, livreiros, impressores, pedreiros, pequenos comerciantes e similares (THOMPSON, 2002, p.16).

Seguindo a mesma pista, além de focalizar este estudo nas três últimas décadas dos oitocentos, não é intenção encontrar "a classe" pronta e acabada no período pesquisado. Interessa observar um processo de formação. Mesmo este, ainda não resultaria num produto absoluto e homogêneo, razão pela qual a presente tese não entra na disputa pelo termo "operário", considerando mais seguro o uso de outros como "classes trabalhadoras" ou o mais difuso, porém mais inclusivo "classes populares".

Quais seriam os padrões de experiência anunciados? Em primeiro lugar, trata-se de homens, mulheres e também crianças ${ }^{50}$ que vivem de seu trabalho. Assim estabelece o conjunto dos estatutos que impõem, entre as condições para ser sócio de muitas organizações mutualistas e beneficentes, a exigência do exercício de algum ofício, além de condições físicas para o trabalho. Tomemos o

50 As crianças fazem parte do universo estudado não só como filhos e filhas de sócios das organizações, mas como ativos no mundo do trabalho, por mais que o Estado em seus pareceres aos estatutos das associações procurassem restringir sua participação em prol de uma concepção de infância que não era consensual naquela sociedade. Este mesmo comportamento de delimitação das fases da vida e dos espaços e atividades adequados a cada uma delas é encontrado nos regulamentos dos cursos públicos noturnos para trabalhadores que interditavam a presença de menores, ainda que, na prática, estes frequentassem as aulas noturnas. 
exemplo da Sociedade Auxiliadora das Artes, Ofícios e Beneficente dos Sócios e Suas Famílias, pois nos permite perceber que não se desenvolvia ali tão somente ou prioritariamente a prática de caridade, palavra sem lugar entre sujeitos de condições socioeconômicas muito próximas. De acordo com o artigo quarto: "ninguém poderá ser sócio sem as seguintes circunstâncias: $1^{\circ}$. Ter bons costumes e ser livre; $2^{\circ}$. Ter aprendido alguma arte ou ofício mecânico ou alguma arte mista; $3^{\circ}$. Ter pelo menos, um rendimento de $200 \$$ rs. Anuais".

A Sociedade Concórdia Beneficente Vinte e Oito de Abril admitia como sócios ilimitado número de pessoas de ambos os sexos, idade até 60 anos, sem distinção de cor e nacionalidade, moradores da Província do Rio de Janeiro, Corte e arrabaldes. O recrutamento era amplo tendo, entretanto, que declarar profissão e perfeito estado de saúde. Da mesma forma a Sociedade Bem Estar dos Caixeiros no Rio de Janeiro, não aceitava o ingresso de "desempregados, pronunciados ou sentenciados por todo e qualquer crime". Para os sócios que fatalmente perdessem seu emprego, buscar-se-ia reempregá-los, fornecendo-lhes os meios de subsistência até se encontrarem reempregados. É o que indica o artigo nove de seus estatutos - dos deveres da sociedade para com os sócios: "Aos que se desempregarem, dar moradia, alimento, roupa lavada e engomada, e proporcionar-lhes ocupação adequada a seu préstimo; aos que não for possível empregar ou se não deem bem moral ou fisicamente, pagar as despesas de transporte para qualquer província do império, procurar recomendá-los para serem empregados logo que chegarem a seu destino". O grande problema para os sujeitos que compunham as diversas associações era estarem privados de trabalhar, por doença, idade, desemprego, prisão. Mais tarde, o problema se desdobrará em não só a possibilidade do trabalho como também nas suas condições: jornada de trabalho, salário, direitos trabalhistas.

Direitos, prerrogativa do trabalhador enquanto cidadão. Como entender a luta do maior contingente de trabalhadores da nação - os escravos, alijados da cidadania, e outros em condições muito próximas - os libertos, portadores de uma cidadania restrita e estigmatizada? Tanto a nova historiografia da escravidão como a do trabalho têm mostrado cada vez mais que não havia grande separação no universo de trabalhadores escravos, libertos e livres. Especialmente no ambiente urbano, conviviam muito próximos. Mas, o aspecto que nos interessa ressaltar aqui é o da proximidade de suas lutas e de suas formas de organização. Tanto que, muitas associações regulares e aprovadas pelo Conselho de Estado, precisavam interpor cláusulas em seus estatutos que deixassem bem explícita a vedação aos escravos, excedendo, por vezes, a restrição aos libertos e à pessoas de cor preta. Em que pese esta característica movida, em grande parte, por uma exigência jurídica da lei que regulava a atividade associativa, a partir da segunda metade do século XIX a postura no mundo do trabalho era de solidariedade. 
Em todo caso convém esclarecer que a posição das sociedades mutualistas operárias com respeito à escravidão, sobretudo a partir dos anos 1870 , é muitas vezes abertamente contrária a essa forma de exploração do trabalho. Algumas dessas associações contribuem para a campanha abolicionista, como a Associação Tipográfica Fluminense que, em março de 1879, promoverá conferência de Vicente de Souza intitulada "O Império e a Escravidão; o Parlamento e a Pena de Morte". Da mesma maneira, nas últimas décadas do século, muitas sociedades assumem, quando possível, posições republicanas. Certamente não é coincidência que, em 1880, fizessem parte do "Corpo Consultor" do já mencionado Corpo Coletivo União Operária notórios abolicionistas ou republicanos, tais como André Rebouças, Benjamim Constant, Vicente de Souza, Joaquim Saldanha Marinho (BATALHA, 1999, p. 64).

Mesmo diante da tendência recente da historiografia que argumenta de modo convincente que os escravos devem ser considerados trabalhadores (BATALHA, 1999), ainda é dado maior destaque a organizações de homens livres, entre os quais tinha forte influência o imigrante europeu. Sendo o grande contingente de trabalhadores cativos, num país escravista caberia entrelaçar de modo mais estreito a história de suas formas de autodefesa, resistência e lutas com a formação de nosso "mundo do trabalho". É o que nos leva a pensar o estudo de organizações como o Clube dos Libertos Contra a Escravidão, a leitura de trabalhos como Pão e Liberdade, a história do padeiro liberto João Mattos, que participa de iniciativas de libertação de outros escravos (DUARTE, 2002), ou a biografia de Domingos Sodré, um sacerdote africano (REIS, 2008).

O trabalho de Reis (2008) tem importantes pontos de contato com a abordagem aqui empreendida. Desde as formas de negociação e conflito adotadas por sujeitos subalternizados imersos em relações paternalistas, até a mobilização dos saberes de experiência de tais sujeitos nos seus atos de resistência, passando por meios muito explícitos de organização para conquista da liberdade, como as juntas de alforria. A história de Domingos começa, ou o "encontro" entre Domingos e Reis se dá quando o primeiro é preso por prática de candomblé em ação mobilizada pelo chefe de polícia que resultou num conflito com o subdelegado de área. "Nesse período os chefes de polícia investiram num controle mais rígido das manifestações culturais africanas [pelo potencial de associação a revoltas] ao passo que, muitos subdelegados que tinham que tratar o problema no corpo a corpo do dia a dia optavam por uma política de negociação" (REIS, 2008, p. 25). Desde o princípio temos sujeitos escravos e libertos vistos como detentores de algum poder de barganha nas trocas do corpo a corpo, no dia a dia. E entre as ferramentas de que fazem uso em tais situações está, por vezes, a própria escrita.

Domingos não era adepto da via da revolta para a abolição. "Isso não significa que estivesse satisfeito com a vida de escravizado, apenas que optara por superá-la por outros meios que não a rebeldia aberta e coletiva. Domingos iria investir suas energias na política de alforrias, a tradicional 
forma de emancipação individual negociada - ao mesmo tempo em que estratégia de controle senhorial - no Brasil escravista (REIS, 2008, p. 83). A alforria era a superação de uma das barreiras, talvez a maior delas, na vida desses sujeitos. Após conquistarem a liberdade seguiam-se outras. No caso dos africanos, quando alforriados tornavam-se estrangeiros. A constituição de 1824 não os permitia, como permitia aos libertos nascidos no Brasil, participar da vida política: não podiam votar ou ser eleitos para qualquer cargo, nem exercer ocupação no aparelho governamental em qualquer nível. Era um mundo difícil de sobreviver: só poderiam andar a noite com um bilhete assinado por seu senhor, no caso de escravo, ou por um homem livre, no caso de africano liberto. O mercado de trabalho minguava, entre 1849-50, os escravos e libertos africanos foram proibidos de trabalhar em saveiros que desembarcavam mercadorias dos navios. Houve proibição e cobrança de impostos aos africanos que mercadejavam. Essa pressão fez com que os negros de ganho, em 1857, fizessem uma greve geral de 10 dias contra o imposto para mercadejar, contra a exigência de que um cidadão liberto garantisse seu comportamento e contra o uso da placa com matrícula no pescoço. Mas continuaram não podendo adquirir bens de raiz, não podendo se reunir para festas e rituais. Ainda que algumas autoridades fizessem vista grossa, ficavam sujeitos a gestos de concessão paternalistas. "De nada adiantavam as palavras eloquentes que lemos nas cartas de alforria, segundo as quais os alforriados africanos ou não, seriam a partir dali 'livres como se de ventre livre tivessem nascido'. (...) No entanto, como outros libertos de seu tempo, Domingos conseguiria superar barreiras legais, contornar engrenagens de dominação e negociar algum espaço de autonomia na terra dos brancos" (REIS, 2008, p. 92 e 93).

No que diz respeito às formas de resistência coletiva dos escravos e libertos africanos, Reis aponta o caso da Juta de Alforria chefiada por Domingos e o caso dos Cantos.

Cantos era como se denominava os grupos de negros de ganho que se organizavam de acordo com suas nações para oferecer serviços como carregadores principalmente em locais específicos da geografia da cidade esquinas, braças, becos, cais - que davam o nome desses agrupamentos. (...) A maioria desses trabalhadores dedicava-se a carregar mercadorias e pessoas, mas africanos que tinham outras ocupações também se juntavam nos cantos. (...) O canto era um lugar propício para o papai [Domingos] recrutar clientes e acólitos, para encontrar amigos e instruir discípulos, conversar e saber das novidades daqui e lá da África, tudo feito em língua africana (REIS, 2008, p. 198).

As juntas de alforria eram instituições de crédito dedicadas a libertar africanos escravizados. As juntas, como os cantos eram organizações por filiações étnicas, ou seja, cada nação africana nagôs, hauçás, jejes, congos, angolas, etc. - formavam uma ou mais juntas, a depender do tamanho da nação representada na cidade. A junta dos nagôs, a maior nação da Bahia em meados do século 
XIX, provavelmente se inspirava na esusu, instituição de crédito iorubá. O que vemos aqui é um caso de associação de crédito e auxílio, não como aplicação de um modelo europeu, mas o uso de um costume africano.

No caso da Bahia Silva Campos observou: existiam nesta cidade empresas bancárias africanas destinadas a fazer empréstimos para aquisição de alforrias. Ajustada a quantia e levantado o empréstimo, forro, o devedor passava a trabalhar por sua conta para solver o débito... Os juros pagos pelos devedores permitiam um bom retorno dessas aplicações e ao mesmo tempo promoviam o crescimento do capital disponível para empréstimo a membros escravos... A junta realmente funcionava como mecanismo de solidariedade africana, mas também um negócio em que libertos emprestavam a escravos dinheiro a juros. (...) Não se tratava de filantropia pura ou solidariedade coletiva apenas (REIS, 2008, p. 208 e 209).

Chalhoub $(2003,2007)$ também empreendeu análises sobre organizações de homens negros libertos e, implicitamente, escravos dentro do formato de associações trabalhadoras da época. Tanto a Sociedade de Beneficência da Nação Conga, quanto a Associação Beneficente Socorro Mútuo dos Homens de Cor, remeteram seus estatutos para aprovação do Conselho de Estado, a primeira em 1874 e a segunda em 1873. A primeira tinha como presidente e vice, homens que não sabiam ler e escrever. Situava-se em local de cortiços. Como muitas sociedades da época aceitava "número ilimitado de membros". Seu pedido foi negado com desqualificação de seus membros por aceitarem escravos, serem "da nação conga" e por serem analfabetos. Já o pedido da Associação Beneficente de Socorros Mútuos dos Homens de Cor, causou maior receio ao conselho, por se tratar de livres e libertos que se associavam em torno de sua identidade de cor, o que ia de encontro ao silenciamento desse tipo de conflito imposto pelo governo imperial.

Em primeiro lugar temos aqui associações de trabalhadores negros inseridas num contexto mais amplo de organização de sociedades de trabalhadores com características semelhantes, na Corte, na segunda metade do século XIX. De fato, é incrível a parecença entre essas sociedades de negros e as "sociedades de trabalhadores do Rio de Janeiro do século XIX" estudadas por Claudio Batalha em artigo recente. Lá e cá encontraremos a democracia interna, com grande peso da assembleia de sócios na vida associativa, a igualdade de direitos e deveres, mensalidade baixa, objetivo de angariar novos sócios - "número ilimitado de membros" - tentativa de dar dignidade ao trabalho, garantir a boa conduta moral dos membros e prover auxílios diversos - funeral, doenças, assistência no andamento de processos judiciais. As sociedades negras também tinham artistas nas diretorias, realizavam reuniões a noite ou em casa de associados, congregavam pessoas com pouco ou nenhum acesso à instrução primária. A causa, talvez seja possível resumir assim as metas principais dessas organizações: promover a alforria de escravos e ou apoiar a adaptação de ex-escravos à vida em liberdade. A política dos africanos e seus descendentes era a liberdade própria e de seus companheiros e a organização de tais associações de trabalhadores negros tem de ser reconhecida como capítulo crucial na 
história da formação da classe operária no Brasil (CHALHOUB, 2003, p. 243-265).

O estatuto do Clube dos Libertos Contra a Escravidão, que ao contrário das associações estudadas por Chalhoub, teve a aprovação do governo imperial, é representativo do debate até aqui travado. O Clube tinha por fim a libertação de escravos, a instrução de escravos e libertos, mas também o auxílio mútuo entre seus sócios. Seus sócios, ao que tudo indica, eram libertos, militantes abolicionistas e republicanos, como é o caso do presidente, João Clapp. Inserir o Clube entre as associações de trabalhadores significa considerar o escravo como trabalhador capaz de se organizar e lutar coletivamente por seus direitos. Ainda que o escravo não fosse sócio formal (o era o liberto) e só pudesse frequentar as aulas com consentimento expresso de seus senhores, uma vez ligado à associação, ele se inseria em seu espaço educativo/formativo, não só na prática sistemática das aulas noturnas e oficinas, mas naquela mais difusa que podia acessar ao circular por aquele espaço, estabelecendo sociabilidades. Em geral, as características do Clube eram bem próximas de outras associações mutualistas $^{51}$, exceto no que diz respeito à compra de alforrias. Aproximava-se delas inclusive na estratégia de adequação para obter seus fins dentro da ordem estabelecida, como consta no artigo nono das Disposições Gerais a intenção de "evitar questões judiciais e envidará todos os esforços para conseguir seus fins por meios amigáveis, mediante acordo com os interessados".

Três traços são marcantes nas experiências apresentadas até aqui: a necessidade do trabalho, as precárias condições de vida e um espírito coletivista, aplicado, inclusive, nas tentativas de sanar tais precariedades. Esta sorte não estava presente apenas no cotidiano de sujeitos sem ofícios ou desempregados. Também encontramos queixas do artista, trabalhador especializado, em relatórios de associações e na imprensa operária. É interessante perceber na bela caracterização da situação francesa no século XVI feita por Davis (1990), uma similitude com a realidade tratada aqui. Segundo ela, a pobreza que esperamos encontrar entre os homens que não tinham qualificação alguma, que faziam serviços avulsos quando os encontravam, também era o fardo do oficial qualificado e mesmo entre seus mestres. Circunstâncias da vida como ter muitas bocas para alimentar, ser dispensado, ficar doente, engravidar, poderiam ser catastróficas para a vida daqueles sujeitos. "Visitantes observavam que os lioneses sempre sofriam de resfriados e pleurisia e os oficiais gráficos se queixavam de que o trabalho lhes dava artrite. (...) O período pós-parto para as

51 De acordo com os estatutos: O Club dos Libertos Contra a Escravidão fundado em São Domingos de Niterói aos 28 de março de 1881 tem por fim:§ 1. Libertar o maior número possível de escravos. § 2. Socorrer os sócios em caso de moléstia ou perseguição. § 3. Criar escolas primárias noturnas e gratuitas, oficinas de trabalho para receber os sócios ou pessoas estranhas ao Club, devendo os escravos que as frequentarem apresentar consentimento expresso de seus senhores. § 4. Promover concertos, conferências e quaisquer festas em benefício da caixa social, obtida previamente licença da polícia, quando os atos tiverem de passar-se em lugar público ou como tal considerado em direito. Art. 2: O Club admite sócios de qualquer sexo, nacionalidade e religião tendo capacidade jurídica e só lhes impõe o dever de colaborarem ativa e sinceramente na grande obra da abolição do elemento servil. 
mães pobres também lhes custava caro, já que muitas delas trabalhavam ou ajudavam seus maridos. Os ricos, é claro, também ficavam doentes e tinham filhos, mas os efeitos disso sobre os pobres era devastador" (DAVIS, 1990, p. 28 e 29).

Somados aos imprevistos apontados por Davis, outra situação aparentemente recorrente, pela frequência com que os estatutos das associações beneficentes do Rio de Janeiro oitocentista designam-lhe seus socorros era a detenção do sócio. Segundo os estatutos da Auxiliadora das Artes e Ofícios e Beneficente dos Sócios e Suas Famílias “o sócio que for preso criminalmente, a sociedade deverá tratar da maneira de seu livramento...”. Até que fosse provada sua culpa o sócio teria auxílio. Tal recorrência tem a ver com a tênue fronteira entre o mundo do trabalho e o "mundo da desordem". As condições de pauperismo desses trabalhadores faziam com que, muitas vezes, eles convivessem com sujeitos considerados contraventores, ou mesmo, alguns deles, praticassem pequenos furtos. Isso sem contar o fato de serem eles visados e vigiados pela polícia e pela justiça, sequiosas do controle a seus movimentos e costumes preconceituosamente definidos fora dos limites da civilização que se queria implantar.

Os condicionantes de uma existência percebida de forma mais ampla são usados por Savage (2004) para distinguir a classe trabalhadora, não exclusivamente pelos processos de trabalho, mas pelo que chamou de "insegurança estrutural" vivida por todos eles.

Essa formulação nos possibilita reconhecer certas pressões estruturais sobre a vida do operário, embora também pontue a urgência de encaminharmos a enorme variedade de táticas que os trabalhadores podem escolher para cuidar de seus problemas - da luta contra seus empregadores à formação de cooperativas, à demanda de amparo estatal, a tessitura de redes de apoio nas vizinhanças e por aí vai. É tão relevante olhar para as estratégias de vida atualizadas nos bairros urbanos e nos lares quanto o processo do trabalho enquanto emprego, não carece ser visto como o único ou o principal eixo da classe social (SAVAGE, 2004).

Contra essa "insegurança estrutural" se organizavam as associações de auxílios mútuos e beneficência no século XIX como temos visto inscrito em seus fins. O conflito de classes no mundo da produção não era o central naquele momento, nem por isso deixava de existir e já se expressar sutilmente. Sutileza ou ambiguidade entre autoproteção do homem pobre trabalhador e a busca de tal proteção nos círculos da elite. Entre a crítica da estrutura social desigual e a necessidade de deferência aos poderes que mantinham tal ordem. Tal quadro nos remete à caracterização feita por Thompson da ambiguidade de consciência teórica popular como mecanismo de preservação da sobrevivência tendo, de um lado, a "necessidade de seguir a ordenação do mundo e jogar de acordo com as regras impostas...” de outro, "o 'senso comum' derivado da experiência da exploração, 
dificuldades e repressão compartilhada com os companheiros de trabalho e os vizinhos..." (THOMPSON, 2008, p. 21).

Assim se comportavam associações fundadas por trabalhadores, mas com composições, muitas vezes, interclassista. Era o caso da Sociedade Montepio dos Conservadores, fundada por "Joaquim Ferreira dos Santos, João da Silva Augusto e José da Costa Corrêa entre si e outros operários empregados na conservação da via permanente e material rodante da Estrada de Ferro de D. Pedro II e domiciliados na Barra do Piraí, onde a Sociedade tem sua sede e foi instituída em 1881". Como era comum entre outras sociedades beneficentes de trabalhadores, procurava evitar discussões "que não tenham por fim estes princípios [humanitários e beneficentes] e a fraternal convivência entre os sócios". Tal discurso estaria perceptivelmente relacionado ao "abafamento" de conflitos, especialmente de divergências políticas.

A sociedade de Socorros Mútuos Montepio dos Conservadores representaria, então, uma composição de mutualismo ligado à condição de classe e beneficência, expressão de uma relação entre classes. Podemos distinguir, na leitura de seus estatutos, três tipos de sócios: aqueles que apenas pagavam as mensalidades e recebiam as beneficências; os fundadores e envolvidos na administração da sociedade; finalmente, os beneméritos/filantropos, de diferentes categorias, distribuidores de dádivas. Estes são caracterizados no artigo dezoito do projeto de estatutos:

São beneméritos (honorários): $1^{\circ}$ - Os correspondentes a outras pessoas de ambos os sexos quando prestarem serviços ou fizerem donativos estimados em mais de $100 \$ 000$ (cem mil réis).

$2^{\circ}$ - Os médicos, farmacêuticos, advogados, procuradores ou solicitadores que gratuitamente prestarem os serviços de sua profissão estimados em mais de $100 \$ 000$.

$3^{\circ}$ - Os diretores ou empresários de teatro, companhias dramáticas, ou de cavalinhos que derem mais de uma representação em benefício da Sociedade, fazendo o oferecimento com antecedência de mais de 5 dias.

$4^{\circ}$ - Os proprietários, gerentes, ou administradores de estabelecimentos industriais, agrícolas, ou vias férreas que durante um ano derem ocupação a 30 sócios desempregados.

$5^{\circ}$ - As pessoas que por um ano derem asilo, vestuário e sustento a algum órfão protegido pela Sociedade.

$6^{\circ}$ - Os professores e mestres de ofício que por mais de dois anos derem gratuitamente instrução a um órfão protegido pela Sociedade.

Já o artigo vinte e nove do mesmo projeto nos esclarece sobre o tipo de relação prevista entre os sócios - as dádivas promovidas por sujeitos "afortunados" em suas atitudes "humanitárias" deveriam ser retribuídas com "respeito e gratidão". É interessante notar que a sociedade considera a possibilidade dos beneméritos "por sua infelicidade, algum dia virem a precisar [de seus auxílios]". Apesar de sua utilidade para a compreensão das relações dentro e fora das associações pesquisadas é preciso levar em consideração alguns alertas ao uso do termo paternalismo e suas práticas de 
dádiva e deferência. O primeiro alerta está no fato de ser muito genérico, o segundo, está no risco de assumirmos a autoimagem do paternalista como se de fato o "calor humano", a caridade, a "responsabilidade de pai" dos senhores para com os plebeus criassem uma sociedade de uma só classe e apagassem os conflitos. Durante todo o período abordado não deixou de haver divisões entre os governantes e os governados, os da alta e os da baixa posição social.

Apenas se poderia atribuir uma identidade política plena a alguém que fosse 'independente' da necessidade de se submeter a bem feitores: tudo isso é um ponto a favor da visão de uma sociedade de uma só classe. Mas a classe não se define apenas pela identidade política. Para Fielding, a evidente divisão entre os da alta e os da baixa posição social, os bem nascidos e os sem berço, estendia-se como uma fissura colossal por todo o país. (...) Esse é um mundo de patrícios e plebeus. Mas essa polarização das relações de classe não priva os plebeus de toda existência política. (...) A plebe não é, talvez, a classe trabalhadora. Os plebeus talvez não tenham uma definição consistente de si mesmos no que diz respeito à consciência, à clareza de objetivos, à estruturação da organização de classe. Mas a presença política da plebe, 'turba', ou 'multidão' é manifesta. [É a chamada luta de classes sem classes]. Eu hesitaria antes de descrever essa cultura como uma cultura de classe, no sentido em que se pode falar de uma cultura da classe trabalhadora no século XIX. (...) Ao analisar as relações gentry-plebeus descobre-se menos uma batalha encarniçada e inflexível entre antagonistas sociais irreconciliáveis que um campo de força societal. (...) Portanto estou empregando a terminologia do conflito de classe, embora resista a atribuir identidade a uma classe (THOMPSON, 2008, p. 56, 57 e 69).

Mesmo com características corporativas, concepções caritativas e atitudes que empregam ou submetem-se ao paternalismo, é possível perceber a dimensão do conflito em que se inseriam estas práticas associativas, do qual seus membros estão cientes. No relatório da Sociedade de Socorros Mútuos Protetora dos Artistas Sapateiros e Classes Correlativas, vemos expressa a compreensão de que a caridade é obra dos ricos objetivando seu próprio enaltecimento. Os relatores afirmam sua condição material distinta de tais benfeitores "bafejados pela aura da fortuna" demonstrando a existência da divisão social ao se inscreverem ao lado dos "sem pujança". Além dos termos que denotam separação, encontramos em seu discurso outros que expressam agregação, como “companheiros da administração" ou "nossos irmãos enfermos”.

Senhores da Assembleia Geral, da Sociedade de Socorros Mútuos e Protetora dos Artistas Sapateiros e Classes Correlativas, sabeis perfeitamente que não tenho a pujança desses indivíduos a quem as auras da fortuna bafejaram-lhes, por isso não pude fazer rasgos de caridade nem tive nunca em mente essa ideia: a de envolver meu nome em ouropéis! - mas somente cumprir o dever que me impusestes.

Guiado pelos bons companheiros da administração, soubemos observar tudo quanto a nossa lei predisse e impôs, corremos pressurosos às casas de nossos irmãos enfermos, e fazendo justiça fomos levar o socorro a que eles 
tinham direito. Àqueles a quem os dignos filhos de Hipócrates aconselharam outras plagas, prontamente lhes demos transporte, àqueles a quem a existência fora arrancada pela morte, lhes demos sepultura.

No espaço dedicado pelo mesmo relatório ao "Necrológio" vemos mais nitidamente um discurso pesaroso em relação às desigualdades sociais.

Como uma lâmpada que se extingue pouco a pouco, assim finda-se a existência do homem! O que é a vida se não um conjunto de quimeras e alternativas?! Para uns o riso fagueiro da brisa, o contínuo gargalhar entre as flores, o ouro; para outros a opressão tristonha da miséria, o trabalho cotidiano cheio de privações e a libação do mais amargo fel! E assim passam os dias do pobre como os de um condenado arrastando pesadas correntes! Mas a morte, envolvendo todos esses sorrisos e essas lágrimas no seu lectuoso manto, precipita-os no caos enorme do túmulo! Descansem em paz! Morrer é findar o sofrimento!

Apesar de crítica sutil à caridade, ou talvez, à prática interessada da caridade, utilitariamente, ela era bem aceita e premiada por todas as associações pesquisadas. O próprio relator dos sapateiros presta homenagem ao médico, Dr. Cardoso Fontes, "digno e humanitário", "que nunca se negou a dar uma informação, a examinar um sócio, e com sorriso nos lábios e $a$ caridade no coração, tem sido o amigo verdadeiro". Da mesma forma, o artigo décimo dos estatutos da Auxiliadora das Artes e Ofícios e Beneficente dos Sócios e Suas Famílias traz o estímulo ao estabelecimento de laços com Sociedades de idênticos fins, porém também as relações utilitárias com determinadas pessoas que, mesmo fora do seu universo identitário, poderiam prestar auxílios aproveitáveis52.

Uma concepção de classe com necessidades e interesses próprios também aparece nos estatutos da Sociedade Bem Estar dos Caixeiros no Rio de Janeiro que visava indagar, conciliar, promover e asilar a "classe caixeiral". Tais verbos nos remetem ao estímulo da consciência, coesão, ação da classe e solidariedade diante do que os estatutos chamam "as inconstâncias da vida". Entretanto, flagramos a presença de uma ambiguidade entre avanço e conservação, crítica social sem ruptura diante das conveniências práticas, não rara nas bases legais de muitas associações de trabalhadores oitocentistas com fins de auxílio mútuo e beneficência. Ao mostrar-se extremamente política no citado segundo artigo: “dos fins da Sociedade", relega no artigo terceiro a politização em prol de fins materiais de beneficência que não poderiam ser ameaçados. "O fim da Sociedade é puramente a beneficência e por isso não pode admitir em seu círculo, sob qualquer pretexto, discussão ou controvérsia alguma política"53. É importante notar que os estatutos da Bem Estar dos Caixeiros são aprovados em 1835, momento em que ainda se sentia as tensões relativas às agitações

52 Art. $10^{\circ}$ : Compete ao conselho: $\S 10^{\circ}$ : Corresponder-se com mais Sociedades de idênticos fins e conservar relações com as pessoas que possam ser úteis à Sociedade, tanto no Império como fora dele.

53 Grifo meu. 
políticas do período Regencial.

O conflito de classes não se pronunciava apenas na delimitação dos lugares de pobres e ricos, ou na lamentação quanto às injustiças sociais, mas também nas práticas de identificação e coesão percebidas pelo uso de termos como companheiros, irmãos ou o próprio classe que apesar de não se tratar de "classe social" no sentido marxista, denota ainda assim coesão. Além de outras formas de construção identitária como cerimônias e solenidades. A ocasião da tomada de posse de novas diretorias cercava-se de simbolismos, enfeitava-se o salão, contratava-se orquestra, inauguravam-se retratos do presidente, por vezes dos sócios benfeitores ou beneméritos, não raro do Imperador, tido como protetor maior de algumas Sociedades. Dessa forma, laços emocionais eram criados ou reforçados pelos sócios em torno da entidade, ao passo que se demarcava seu lugar na cena pública, especialmente entre outras associações. Era muito comum a presença das "co-irmãs", associações voltadas para os mesmos fins, além da presença da imprensa. O relatório da Sociedade de Socorros Mútuos Protetora dos Artistas Sapateiros e Classes Correlativas aponta a presença de vinte e uma "co-irmãs", entre elas o Congresso Operário de Beneficência, e outras ligadas à comunidade portuguesa, bem como o comparecimento das redações do Jornal do Commercio e do Diário de Notícias.

A prática de historiar a própria associação também revela preocupação com a construção do ser sócio, mas que não deixava de fazer referências a um pertencimento mais amplo - o de operário ou artista. O relatório da Imperial Sociedade Auxiliadora das Artes Mecânicas Liberais e Beneficente apresentado em $1^{\circ}$ de março de 1876 , é aberto por um histórico que se estende desde a formação da entidade, em 1835 até a entrega dos cargos pela presente diretoria.

Tomando distância dos fundadores, o relator mostra que a motivação para a criação da Sociedade por "benevolentes e honrados artistas, pobres filhos do povo" situava-se entre a necessidade aliada à compreensão de uma condição social comum que lhes apontava uma saída coletiva e, por outro lado, a caridade, motivada por sentimentos religiosos cristãos. Porém, conclui que a maior motivação fora, de fato, o auxílio mútuo, uma vez que a caridade é uma moeda que "pertence de direito exclusivamente ao pobre inválido", dos quais se distinguem os obreiros, qualificados como "intrépidos", "robustos" e "fortes". Estes poderiam tirar de sua atividade os meios de sua "subsistência módica".

A questão é que de tão módica, essa existência os sujeitava aos riscos e incertezas de virem a se tornar indigentes, sujeitos à beneficência. Para surpresa do relator, os obreiros, fundadores da associação, estavam cientes disso. Cabe-nos questionar se sua demonstração de espanto ocorrera por tratar de uma geração de sócios diferente, ou se era ele, o relator, quem estava afastado socialmente do mundo dos obreiros. Estes que: 
(...) compreenderam, e, com admirável discernimento, que exaustas as forças pela decadência precoce ou natural de suas faculdades, sempre em movimento afanoso, bem difícil, senão impossível, tornar-se-ia a sua manutenção em tais circunstâncias, e o por vir de seus descendentes, que não previam auspicioso, lhes aumentava os cuidados do presente.

Em tal emergência, apelar para seus irmãos, aqueles para quem a ventura jamais sorria com melhor aspecto, implorando-lhes auxílios ou sobras, que a pobreza não acumula, seria impor-lhes um pesado ônus, não poupando a si mesmos o vexame e os pesares, consequência certa e inevitável das situações dependentes a que seriam condenados sem o menor recurso, não lhes pareceu judicioso alvitre.

Recorrer aos poderosos e abastados, entre os quais o número dos beneficentes era assaz limitado, porque esses felizes da terra, envoltos nas pompas e magnificências, que a opulência ministra e a ociosidade embeleza, indiferentes e soberbos, olvidavam alheios sofrimentos, não se tornaria proveitosa, pois teriam de arcar com a força indômita de impávido egoísmo, de que os resultados prováveis seriam negativos, ou quando muito, de vantagens precárias.

Ao passo que procura construir uma imagem positiva desses "intrépidos obreiros", exaltando sua capacidade de trabalho e organização, também explicita o conflito social que os opõe aos "poderosos e abastados", "envoltos em pompas e magnificências", "opulentos e ociosos", “indiferentes e soberbos", em suma "egoístas". Não chega a questionar o porque da opulência de uns e da modicidade de outros, conformando-se com "a sorte" que teria feito à alguns "felizes e afortunados", sem tocar nas relações de exploração. As relações de exploração eram expostas, mas num limite do discurso de deferência. Aproxima-se levemente da ideia ao indicar que a associação era uma forma desses "corajosos antepassados trabalharem para si", meio pelo qual formaram "o patrimônio dos artistas". Este "trabalho para si" no interior da Sociedade, reconhece o fato de que em seu dia a dia trabalhavam para o empregador.

Se não torna explícita a crítica da estrutura social escravista e capitalista pelo uso do conceito de exploração, pretende por seus atos responder aos problemas que aquela sociedade colocava. Em busca de reconhecimento e elevação moral na cena pública, os relatores defendem o uso deste mesmo patrimônio para fins de caridade aos menos afortunados: "criaturas fracas e tímidas", em risco de serem “engolfadas no imensurável e asqueroso lodaçal do vício”. Vemos estabelecer-se uma disputa simbólica pela construção das representações e da memória social num terreno onde se opõe os "indômitos conquistadores, que inundaram o orbe de sangue e conspurcaram a dignidade humana, tornando escravos os que nasceram livres" e "os desconhecidos obreiros a quem temos aludido". Estes últimos ainda disputariam espaço na memória nacional com aqueles que "conseguiram fundar suntuosos asilos de mendicidade". Mais valorosa, entretanto, seria a beneficência fruto do "[entesouramento de] restos mínimos de exíguo salário para instituírem igualmente um prêmio à virtude". 
Remidas pelos socorros da origem acima designada, muitas criaturas fracas e tímidas, deixaram de engolfar-se no imensurável e asqueroso lodaçal do vício.

A prostituição infrene não esmagou em seus braços de ferro a mulher honesta e honrada que açoitada pelo latego cruento da penúria, ia precipitarse no abismo, porque já prestes a lançar-se na voragem, encontrou ante si a mão calosa e firme do artista para sustê-la, evitando-se assim a desastrada queda.

O enfermo e o moribundo prostrados no leito de dores, envoltos nos andrajos da indigência e abandonados ao acaso, achavam importante lenitivo e conforto para seus acerbos sofrimentos nos recursos dispensados pelos cofres da associação.

Para o órfão, atirado à lama das calçadas, após a morte de seus progenitores, fez-se a luz da inteligência, e farto pão da vida lhe foi distribuído.

Estaríamos diante de uma história de auto-organização dos trabalhadores, consciência dos conflitos entre pobres e ricos constitutivos daquela sociedade, disputa pela memória social entre os obreiros e a história oficial dos conquistadores e escravocratas, porém os valores arraigados da caridade e da moral cristã eram persistentes, ocupavam o lugar do valor da igualdade de direitos e de sua conquista por meio de um processo de transformação social. Nesse sentido a intervenção social dos "artistas mecânicos e liberais" deveria se dar pela proteção benevolente, caridosa, àqueles refugos da sociedade, que não eram "fortes e robustos", dignos, ainda que módicos. Todo um conjunto de "outros" habitantes da cidade, objetivados pelo olhar dos bons obreiros, tornavam-se indistintos, objetos, como talvez o fossem, ao olhar dos ditos afortunados, assemelhados também os obreiros. Há que se lembrar, entretanto que a dádiva ou caridade e a conquista de direitos não eram, naquele momento, termos completamente opostos. Thompson (2008) delimita três traços gerais acerca da caridade: 1- como sinal de sacrifício perante Deus; 2- como sinal de prestígio, implica subordinação; 3- a obrigação da retribuição gerando controle social. Mas a dádiva vista a partir de baixo revela outros aspectos, como sendo um modo dos pobres tirarem o máximo que podem dos ricos, além de que o beneficiado pode não se sentir em obrigação com o doador. Ele lembra ainda que há contextos específicos de dádivas, e até exemplos de generosidade desinteressada, ou seja, “não existe essa constante no 'ato de doar', com caracteres constantes, passível de isolamento dos contextos sociais particulares" (THOMPSON, 2001, p. 248).

Outro caso de Sociedade de operários dedicada a atos de beneficência mais extensivos é o do Congresso Operário de Beneficência, criado em 29 de abril de 1883 e convertido em Congresso de Beneficência e Instrução em 1889. A requisição de proteção ao Imperador ${ }^{54}$, datada de janeiro de 1884, dá notícia de sua fundação por "um conjunto de operários crentes no futuro e fortalecidos no trabalho diário da oficina". Em sua primeira sessão estavam presentes em número superior a cento e

54 Localizada entre os documentos da Casa Imperial, caixa 17, pacote 9, documento 134 do Arquivo Nacional. 
cinco, unidos pelos intuitos de "Proteger as viúvas dos operários, educar os órfãos deixados por estas, auxiliá-las nas suas enfermidades longas, em fim, procurar por todos os meios lícitos a proteção para esses heróis obscuros que conquistaram nas oficinas a honra de uma vida trabalhadora e limpa".

As alterações realizadas nos estatutos, em 1889, expressas também na mudança do nome da entidade, não descartam os fins anteriores, entretanto, acrescentam novas atribuições e suprimem a identificação específica de "operário". Sua composição, de acordo com a nova versão é ampla: “ilimitado número de sócios, de qualquer sexo, nacionalidade e religião, nas condições previstas no artigo 1655”. Sobre a presença das mulheres este artigo atesta que eram aceitas caso fossem propostas ou tivessem autorização dos que "legalmente as patrocinem": pais, irmãos, maridos, tutores ou filhos.

Entre as novas atribuições da Sociedade estava a manutenção de "um curso teórico e prático para os associados e seus filhos, podendo o conselho administrativo do congresso desenvolvê-lo e até declará-lo público desde que o permita os recursos da respectiva caixa especial”. É importante perceber, para os fins desse estudo, o fato de uma organização de caráter popular, visível em sua amplitude de admissão, seus fins de auxílio aos sócios enfermos, às viúvas e órfãos de sócios falecidos, o socorro aos sócios inválidos, baixo valor para o diploma de sócio contribuinte, além da "não indiferença a seus associados sob pressão da justiça ou de meios de subsistência por falta de trabalho", atribuir elevada relevância à instrução de seus membros, estabelecendo para isso meios formais de difusão.

A dimensão desta preocupação pode ser percebida pela existência de uma caixa específica para o financiamento do curso56, a manutenção de uma biblioteca e a titulação de professores e

\section{Art. 16. Para ser admitido no Congresso é preciso:}

$\S 1$. Ser de bons costumes, nunca de idade menor de 15 anos nem maior de 70 , sendo que os candidatos de mais de 60 só poderão ser recebidos entrando de uma vez com a quantia de $100 \$$, além da quota do diploma de remido.

$\S 2$. Estar no gozo de perfeita saúde, podendo contudo, ter algum defeito físico, contanto que deste não se prevaleça mais tarde para requerer os socorros sociais.

$\S 3$. Residir no Município Neutro ou em Niterói, dentro dos perímetros servidos por linhas de bonds ou pelo trem de subúrbios da Estrada de Ferro D. Pedro II.

$\S 4$. Ser proposto pelo conselho administrativo por qualquer sócio no gozo de seus direitos e sob a responsabilidade deste (não compreendida a falta de pagamento de mensalidades) declaradas na proposta o nome, naturalidade, idade, estado, profissão e residência do candidato, e se tem algum defeito físico. Esta proposta depois de discutida será votada em conselho.

As propostas para sócias apresentadas por outros que não sejam seus maridos, pais, tutores, filhos ou irmãos, deveram acompanhar autorização daqueles que legalmente às patrocinem.

56 Art. 40. A contar da data destes estatutos, formarão receita da Carteira escolar:

$\S 1$. A quota de $25 \%$ do produto das entradas, mensalidades e remissões dos sócios do Congresso e a de $50 \%$ do que trimestralmente produzir a Caixa de beneficência das sessões.

$\S 2$. Subvenção do governo geral ou municipal, benefícios e qualquer auxílio ou coleta especialmente destinados a manutenção do curso.

$\S 3$. Produto de venda de objetos.

$\S 4$. Dito de $2 \$$ por certidão extraída dos livros de escrituração do curso. 
consultores do curso como beneméritos, benfeitores e honorários, lembrando que entre os sócios honorários estava o próprio Imperador. Bem organizado, havia um capítulo inteiro dos estatutos que prescrevia seu funcionamento, confirmando o regulamento criado em 1888 para as aulas. Indicava também a existência de uma congregação que o regia, dando-lhe certa autonomia, mesmo sendo o diretor indicado pelo Congresso, como podemos observar no parágrafo 5 do artigo 69 - Do Curso onde se lê que: "As sessões da congregação não serão secretas para os membros da diretoria do Congresso, que nelas não poderão, entretanto, discutir, sem que a isto sejam especialmente convidadas, e nunca votar".

$\mathrm{Na}$ economia dos dons e contra dons, aplicada de alto a baixo na sociedade imperial, ter o Imperador como protetor era uma forma de conquistar aceitação social e proteção para estas entidades, além de favores pessoais, dádivas que deveriam ser retribuídas com a devida deferência. Em seu relatório a Imperial Sociedade Auxiliadora das Artes Mecânicas e Liberais e Beneficente marca a homenagem feita à Sua Majestade, no ano de 1863.

O Conselho, desejando manifestar à Sua Majestade o Imperador, augusto protetor da Sociedade o quanto a mesma se achava cheia de júbilo por ter a Divina Providência preservado a sua augusta pessoa do desastre ocorrido na Fortaleza de São João no dia 7 de agosto do ano próximo passado, enviou uma comissão para felicitar o mesmo augusto senhor por tão plausível motivo, e querendo mais dar um público testemunho do quanto prezamos a preciosa existência do nosso augusto protetor, que tantas graças nos tem prodigalizado, resolveu mandar celebrar um solene Te Deum em ação de graças, que teve lugar na Igreja dos Terceiros do Carmo no dia 23 de agosto do ano próximo passado.

A proteção do Imperador derivava favores bem concretos, o que nos permite ver como as Sociedades eram catalisadoras de laços/redes mais amplas, ligando alguns de seus membros às esferas do poder em maior ou menor escala, dependendo de como era composta e do caráter da Sociedade. Havia, entretanto, gradações nos favores e limites ao trânsito dos indivíduos nessas redes. A nomeação do Sr. Antonio de Pádua e Castro para lente da cadeira de escultura e ornatos da Academia de Bellas Artes pode ser um caso exemplar. Dificilmente veríamos um membro de uma Sociedade de artistas mecânicos e liberais ser nomeado para um alto cargo no Império.

Nomeou-se igualmente uma comissão para agradecer à Sua Majestade Imperial por ter-se dignado nomear ao sócio benemérito, o Sr. Antonio de Pádua e Castro para lente da cadeira de escultura e ornatos da Academia de Bellas Artes, e bem assim para felicitar o nosso consócio por tão justa escolha de Sua Majestade, o que muito lisonjeia a nossa Sociedade, por ter

$\S 5$. Dito de $2 \$$ de cada certificado impresso de exame de ex-alunos.

$\S 6$. Juros de apólices compradas em nome do curso.

$\S 7$. A quota de $25 \%$ líquida de despesas, donativos, benefícios, quermesses, matinées e qualquer outra coleta ou auxílio em favor do Congresso, sem designação especial de Carteira. 
sido feita em um dos seus dignos membros.

Podemos ver neste episódio motivações adicionais para alguns sujeitos empenharem-se em serviços no interior das Sociedades onde havia trocas de proveitos entre coletividades e indivíduos. Talvez, como sócio comum, não benemérito, Antonio de Pádua Castro não tivesse obtido a atenção do Imperador. A lógica dos favorecimentos e da caridade, entretanto, era apenas uma das faces do complexo universo das associações populares em um período de mudanças políticas e sociais em curso.

Essa complexidade dos últimos anos do século XIX no Brasil tem expressão no Programa da Seção Solene do Corpo Coletivo União Operária Comemorativa da Independência do Império em 7 de Setembro de 1885, tipo de fonte que consegue resumir o espírito de uma época. Ao lê-lo encontramos um poeta republicano - Otaviano Hudson - recitando uma poesia dedicada à Princesa Isabel, numa solenidade de uma União Operária que exorta "Deus, trabalho e patriotismo". O documento registra, antes de mais nada, um exercício prático de deferência daqueles operários aos poderes paternalistas ainda hegemônicos no momento. Não seria mais o paternalismo do senhor de escravos, centro do poder privado colonial, pois honrar a figura do imperador como protetor, não significava necessariamente apoiar o sistema escravista ${ }^{57}$.

Em meio a esta ebulição, entre a corrosão do regime monárquico a partir de sua base de sustentação, a escravidão, e a proteção à figura do imperador e do arcabouço do Estado preservado com a República, vemos transformarem-se também as características das organizações de trabalhadores. Temos na Sociedade Beneficente Amparo Operário um exemplo de associação classista antes da primeira década do século XX. Seus fins eram os mais amplos possíveis: "Amparar e socorrer os operários seus associados em todos os casos que necessitarem e socorrer suas famílias". O número de membros era ilimitado, mas restrito a operários e artistas, e entre eles os de "comportamento reconhecido". Não se distinguia cor, idade ou nacionalidade, mas não se

57 O Programa da Sessão realizada no Imperial Teatro S. Pedro de Alcântara à 1 hora da tarde consistia em: 1- Hino da independência executado pelas Exmas alunas do conservatório de música e por bandas marciais sob a direção do cavalheiro Archangelo Fiorito. 2- Abertura da seção - solicitando a vênia imperial pelo presidente do Exmo Conselho Sr. Conselheiro Manoel Francisco Correia. 3- Discurso oficial - orador o Exmo Sr. Conselheiro d'Estado, Senador João Lins Vieira Cansansão de Sinimbú. 4- Saudação poética a S. M. A Imperatriz, pelo operário do Arsenal de Marinha da Corte Manoel Benevenuto de Lima. 5- Carmem- Fantasia, pela banda de artífices da Marinha sob a direção do professor José de Campos. 6- Agraciados pela União Operária. 7- Poesia dedicada a S. A. a Princesa Imperial, recitada por Otaviano Hudson. 8- Fuber, de Weber - Ouvertura pelas bandas dos menores do Arsenal de Guerra, Corpo de Polícia da Corte, Batalhão de Engenheiros e Escola Militar, sob a direção do professor Joaquim P. De Carvalho. 9- Felicitação aos agraciados pelo membro honorário Dr. Arthur Fernandes Campos da Paz. 9- Deus Trabalho - Patriotismo - Poesia distribuída. 10- Pout-pourri da ópera Trovador, pela banda de Artífices do Arsenal da Marinha, sob a direção do professor João Alves. 11- Manifesto da União Operária oferecido à S. M. O Imperador. 12- Marcha D. P. II - composição do saudoso membro honorário maestro Romualdo Pagani, sob a direção do professor Joaquim P. De Carvalho. 13- Agradecimento da Presidência. 14- Hino da Independência - sob a direção do cavalheiro Archangelo Fiorito. 15- Levantam-se as saudações de estilo à Família Imperial. 16- Hino Nacional por todas as bandas regidas pelo professor J. P. De Carvalho. 
mencionava a diferença de sexo. É interessante notar que aceitam sócios "logo que estejam em pleno gozo de seus direitos civis e políticos". Esse condicionamento de tempo poderia ser tanto uma espera para que o sócio atingisse idade adequada, ou talvez para que o sócio obtivesse a liberdade, ao que temos a expectativa do ingresso de trabalhadores ex-escravos.

O artigo décimo reafirma a necessidade de ser "artista ou operário" para associar-se. E no artigo décimo quarto se lê: "Poderão ser admitidos sócios todos os artistas e operários de todas as artes e ofícios". Em nenhum momento se faz restrição expressa à presença de escravos. As mensalidades são baixas e não há diferença entre as quantias pagas pelas diferentes categorias de sócios. Estas categorias se distinguem por títulos obtidos por serviços prestados. Havia ainda uma titulação de benfeitor àqueles que prestassem relevantes serviços à sociedade, como: médicos, boticários, advogados. Estes não seriam, porém, incorporados como sócios, como acontecia em muitas outras sociedades, descaracterizando o pertencimento de classe daquelas. Outro fator interessante, que distingue esta da maioria das associações correlatas é o da nomeação dos funcionários da sociedade. Esta se daria, segundo as Disposições Gerais, prioritariamente entre "os sócios que saibam exercer a função", mas em nenhum momento vincula "saber exercer a função" ao elemento alfabetização, aspecto restritivo em várias sociedades no período estudado.

Entrando pelo século XX já se torvam mais visíveis os contornos da classe trabalhadora, o que ela valorizava e almejava: coesão, harmonia entre seus pares, proteção para si e para a família, uma casa, instrução para os filhos e também para si. É o que nos informa o resumo sobre a Associação Beneficente do Corpo de Oficiais Inferiores da Armada na publicação sobre Assistência Pública e Privada no Rio de Janeiro. Os fins dessa associação fundada em dezembro de 1907 seriam:

Promover a harmonia entre os diversos elementos de que se compõe o corpo de oficiais inferiores da armada, auxiliar despesas de funeral e luto das famílias, criar uma caixa de previdência doméstica para socorrer os sócios enfermos sob forma de empréstimo, manter um montepio para quem queira participar, uma caixa predial que faculte ao associado ou seu herdeiro a aquisição de prédio, por sorteio, para sua própria moradia. Estabelecer aulas gratuitas de ensino primário e secundário e cursos militares, profissionais e de educação física para os associados, seus filhos e tutelados, empenhar-se por colocação em instituição de ensino ou trabalho os filhos tutelados dos associados falecidos, manter biblioteca para gozo dos sócios com uma comissão para os visitar quando enfermos, finalmente prestar, nos limites da disciplina, todo auxílio moral que necessite o associado em qualquer emergência da vida civil. Aos associados sujeitos a processo criminal no foro civil ou no militar, presta a associação socorros judiciários.

No mesmo sentido a Associação de Marinheiros e Remadores, fundada em outubro de 1904, 
buscava a união dos sujeitos trabalhadores de um mesmo ofício, era democrática, não fazia distinção de raça, religião, ou nacionalidade, marcas discriminatórias naquela sociedade. Atribuía importância à educação primária e profissional, além de meios mais ou menos autônomos para se educarem como a publicação de uma revista e manutenção de uma biblioteca. Encontramos a constante contradição entre não poder tratar de assuntos políticos sob a justificativa de serem esses, causa de divisão do operariado deixando ver o embate entre os fins políticos e os fins "práticos" assistenciais.

A hegemonia de um caráter classista tendendo ao formato sindical entre associações de trabalhadores na passagem para o século XX não exclui suas funções de auxílio mútuo, nem muitas das contradições existentes em seu interior durante o período imperial. A Liga Federal dos Empregados em Padaria no Rio de Janeiro era uma das que, além do objetivo da união de classe, preocupava-se com o socorro às moléstias, a defesa judicial quando presos ou processados, $\mathrm{o}$ enterro dos sócios, garantia de ocupação para eles, manutenção de biblioteca e escolas para estudar o português. Até aí não se distingue tanto de outras associações. Distingue-se ao propor aulas de esperanto (considerado como possível língua veicular entre a classe operária) e avança ao propor uma cooperativa operária de panificação.

A Sociedade de Resistência dos Trabalhadores em Trapiches e Café fundada em abril de 1905, segue essa mesma linha com um caráter mais reivindicativo. Segundo os dados apresentados na publicação estatística sobre Assistência Pública e Privada no Rio de Janeiro:

É uma associação de classe, compondo-se exclusivamente de trabalhadores em trapiches e café e tendo por divisa "um por todos e todos por um". Em seus estatutos aprovados em assembleia Geral de 20 de maio de 1905 e reformados em assembleia geral de 30 de junho de 1906, há o seguinte artigo que define na íntegra sua composição e fins: art. 2: esta associação é de ilimitado número de sócios, sem distinção de nacionalidade, cor, e religião, pois os seus fins são procurar a união de todos os trabalhadores e organizar sociedade de classe que tenham os mesmos fins. Seus associados são exclusivamente adultos do sexo masculino. [E tem por fins]: proteger e defender os seus associados, como trabalhar pelo levantamento moral, intelectual e material da classe; organizar o trabalho de trapiche e café e a diminuição das horas de trabalho e aumento do salário, tanto no trapiche quanto no café e outros trabalhos correlativos ao mesmo. Prestar defesa gratuita obrigatória em caso de prisão, perseguição injusta, ou abusos de que seus associados possam ser vítimas, fundar uma caixa de resistência para auxiliar e defender seus associados em caso de greve ou quando se virem coagidos em sua liberdade, em defesa da classe, de acordo com a letra d do artigo 2. Esta associação é federada a Federação Geral dos Transportes Marítimos e manterá a sua representação junto à mesma. Os delegados junto a federação serão eleitos por maioria de votos e com plenos poderes para defenderem os direitos da Sociedade à Federação. Envidar todos os esforços para resolver amigavelmente todos os atritos que se derem entre trabalhadores e patrões, submetendo-os em caso de arbitramento à juízo da 
federação já consignada. Esta associação procurará por todos os meios lícitos firmar pacto de solidariedade com todas as associações congêneres no Brasil como no estrangeiro dando livre admissão aos seus associados. Festejar o dia 15 de abril como data de sua fundação e o dia $1^{\circ}$ de maio. Criar aulas de instrução, jornal de propaganda, uma biblioteca quando os recursos sociais o permitirem e promover conferências e publicações que interessem à classe e sejam para ela outros tantos elementos de instrução e educação cívica. Fornecer auxílio pecuniário aos sócios enfermos como também para o funeral dos mesmos dentro da capital ou Niterói.

O Dicionário do Movimento Operário organizado por Claudio Batalha (2009) acumula exemplos de associações, nos primeiros anos do século XX que definem seu caráter de classe sem perder as funções mutualistas. É o caso da Associação de Classe União dos Pedreiros que tem em seus estatutos a norma: “A associação será composta exclusivamente de operários pedreiros. Os mestres poderão ser admitidos desde que conforme $a l e i^{58}$, ficando, porém, privados de votar e ser votados". Logo em seguida encontra-se a Associação de Resistência dos Cocheiros Carroceiros e Classe Anexas, fundada em 1906. "Nessa época os fins da associação eram intervir nos conflitos entre patrões e associados, criando para isto uma caixa de resistência; defender os interesses dos profissionais, procurando obter por meios legais o aumento de salário e a diminuição de trabalho, prestar auxílio médico, farmacêutico e pecuniário em casos de acidente de trabalho, defender os associados, caso fossem presos por delito profissional e comemorar o $1^{\circ}$ de maio". O que se conseguia, antes, "pedindo humildemente" pelo apoio de figuras ilustres em forma de favor, agora se procurava obter por embate direto com os patrões, forma de luta por reconhecimento de direitos. A grande mudança que se observa neste momento é o fim da estratificação socioeconômica no interior das associações de trabalhadores de cujo vocabulário a palavra beneficência vai sendo eliminada.

\section{3- As normas disciplinares e penalidades}

Os estatutos de todas as Sociedades pesquisadas dão ênfase aos critérios disciplinares tanto para admissão como para a manutenção dos sócios. Questões de moralidade e ordem eram muito importantes entre organizações que pleiteavam reconhecimento público e jurídico, compostas por sujeitos tidos pela ideologia dominante como viciosos, desordeiros, perigosos. Práticas como o alcoolismo eram passíveis de penalidades prescritas, como o caso de Vitorino da Costa Mó, sócio da Protetora dos Sapateiros e Classes Correlativas, diagnosticado pelo Dr. Cardoso Fontes como sofrendo de alcoolismo crônico, por este motivo teve suspensa a beneficência de que desfrutava por

58 Grifos do autor. 
meio dos cofres da Sociedade.

Já as leis da Sociedade dos caixeiros demonstram um corporativismo exacerbado e rígidos critérios de admissão baseados nas concepções de ordem vigentes. O artigo sexto indica que apenas caixeiros, guarda livros e feitores de comércio podem ser propostos para sócios efetivos. Seu número é ilimitado excetuando-se:

$\S 1^{\circ}$ : Os desordeiros, os de maus costumes e os que não tenham uma ilibada, ou regular conduta na carreira comercial.

$\S 2^{\circ}$ : Os desempregados, pronunciados e sentenciados por todo e qualquer crime.

Diante desses critérios penalidades eram estabelecidas àqueles que "se derem a prática de maus costumes" ou "forem presos por crime infamante". Desde o momento que não definem o que são "maus costumes" ou "crimes infamantes" instalam em nós, observadores de outro tempo, a dúvida se tal redação colocava seus sujeitos em consonância com o sistema de valores e penas do Estado nacional brasileiro ou se, em sua generalidade, abriam brechas para a adoção de um código próprio.

Eram comuns as exigências quanto à condição de liberdade - é preciso ser livre, e a condição de moralidade, é preciso ser "bem morigerado". Fora qualquer outro motivo de ordem ideológica dos membros, a reafirmação dessas restrições era condição para atendimento das exigências do governo imperial para aprovação dos estatutos, logo, do reconhecimento da existência da própria entidade. A tênue linha que separava, nas relações sociais, trabalhadores livres e escravos levava a uma constante preocupação dos primeiros em afastar-se daquilo que pudesse os vincular aos segundos.

Por mais baixas que fossem e, em alguns casos, por serem mais altas que a média, as joias de entrada, as mensalidades e critérios de renda anuais também podem ser considerados fatores restritivos, ainda que compreendido o elemento protecionista nestas medidas. Elas nos sugerem a heterogeneidade no universo das classes populares, tanto em termos de condições materiais quanto de hábitos. Os sujeitos que optavam por se associar a outros não pareciam estar completamente à margem da sociedade, tendo condição e predisposição em reservar recursos, mesmo que pequenos, em função de prevenções para o futuro. Esses em geral, eram os que também se mobilizavam em torno da instrução como estratégia traçada em direção a melhores condições de vida. E, por fim, encontravam-se, de fato, mais protegidos contra o empobrecimento excessivo e mais propensos aos processos de ascensão social.

Apesar de formalidades e rigor para admissão de sócios e dos critérios disciplinares para sua manutenção, depois de admitido é possível observar um sentimento solidário mais pronunciado em 
algumas Sociedades, como é o caso da Auxiliadora das Artes e Ofícios e Beneficente dos Sócios e Suas Famílias que permitia o pagamento da beneficência mesmo sem quitação de mensalidades em atraso nos casos em que a indigência fosse comprovada. A entidade fazia uma avaliação da situação do sócio enfermo e dos recursos em caixa para estabelecer o valor da beneficência e aconselhava que este se mantivesse participativo no desempenho de alguma atividade compatível com suas condições em seu interior. No tratamento ao sócio que fosse preso criminalmente auxiliava-o até que fosse provada sua culpa.

O mesmo documento nos permite perceber que a grande preocupação das autoridades em relação às classes populares não recaía sobre "qualquer crime": o furto estava literalmente previsto, e ganhava destaque nos estatutos. Nos pareceres dados pelo Conselho de Estado era recorrente a ênfase nas medidas disciplinares contra os ataques à propriedade, à vida e à honra. No caso da aprovação aos documentos da Associação Bahiana de Beneficência, em dezembro de 1880, vemos um parecer, no mais dos aspectos, favorável, com a recomendação de que "no $34^{\circ}$ artigo se substitua a palavra - infamantes - por estas: contra a vida, a honra e a propriedade". "Crimes infamantes" seria um termo muito genérico quando deveria ficar bem claro o sentido do controle sobre as classes populares.

O governo imperial, representado pelo Conselho de Estado, procurava interferir e direcionar as regras e funcionamento internos daquelas associações, mas estou de acordo com Thompson (2002) quando constata, na formação da classe operária britânica, que a organização interna das sociedades, a tomada de consciência dos trabalhadores, sua disciplina, não eram impostos por uma força externa, mas fruto de suas necessidades ${ }^{59}$. Segundo ele, "o movimento dos trabalhadores

59 Não é a intenção avolumar este trabalho com citações, mas reproduzo em nota o trecho a seguir, embora extenso, interessante para observarmos similaridades, guardadas as muitas e devidas proporções entre o processo de formação da classe operária britânica trazido à luz no clássico trabalho de E. P. Thompson e a realidade das associações de trabalhadores no Rio de Janeiro a partir de meados do século XIX aos primeiros anos do XX. "Pequenos artífices, artesãos e trabalhadores, todos tentavam garantir-se frente aos riscos de doença e desemprego, e às despesas funerárias, participando de box clubs ou de sociedades de auxílio mútuo. A disciplina necessária para a custódia dos fundos, para a condução organizada das reuniões e para a resolução de situações controversas exigia um autocontrole tão grande quanto a nova disciplina de trabalho (grifo meu). (...) Todas as Sociedades Gerais impunham multas sobre qualquer membro que "censurasse" outro por estar recebendo o auxílio enfermidade, que bebesse durante o Sabbath, batesse em algum colega, chamasse alguém pelo apelido entrasse embriagado na sala da associação, ou invocasse o nome de Deus em vão. A Fraternidade dos Preparadores de Malte acrescentava multas por embriaguez em qualquer ocasião e por não cumprimento aos funerais dos companheiros ou de suas esposas. Os vidreiros (cuja associação foi criada em 1755) pagavam multa sempre que faltassem às reuniões, se recusassem a cumprir seu turno na escala de serviços, não mantivessem silêncio quando ordenado, falassem simultaneamente, replicassem ao moderador nas reuniões, fizessem apostas dentro da sociedade, ou (uma regra comum) revelassem os segredos da sociedade. (...) Os remadores, para não ficarem atrás, acrescentavam uma regra excluindo do benefício todo membro que adoecesse por ter se deitado com uma mulher imoral e que contraísse gonorreia ou sífilis. A Sociedade Unânime interrompia o pagamento do auxílio enfermidade de qualquer membro que fosse encontrado em cervejarias bebendo ou jogando. Com a finalidade de manter sua unidade, havia multas para os membros que propusessem discussões ou discursos sobre assuntos políticos ou eclesiásticos, ou sobre o governo e os governantes. A Sociedade de Auxílios Mútuos de Todos os Ofícios tinha sua regra semelhante a respeito dos acessos de raiva nos jogos de dama e uma multa para todo membros que deixasse de denunciar um companheiro quando tivesse oportunidade. Os sapateiros criaram ainda outras regras para os que pediam bebida ou tabaco sem autorização do 
exigia novos atributos como autodisciplina, auto respeito e treinamento educacional. Uma minoria que o possuía parecia lutar arduamente abandonada pela própria classe tendia a olhar ocasionalmente para seus companheiros trabalhadores com aversão e desprezo" (THOMPSON, 2002). Havia, também 'uma expectativa, inclusive, de que, quando os 'cavalheiros e magistrados' constatassem a sua disciplina, 'tenderiam a reverenciar ao invés de punir semelhante sociedade"' (THOMPSON, 2002, p. 309).

Diante de possíveis relativizações não se deve pensar que haveria um abandono da ordem estabelecida, pois tendo sido o sócio julgado e condenado, lhe seria negado o benefício e a Sociedade se desobrigaria de sua defesa em caso de reincidência, porém, ainda assim o conselho lhe prestaria os benefícios "que julgasse convenientes". É o que mostram os seguintes artigos da Auxiliadora das Artes e Ofícios e Beneficente:

Artigo $37^{\circ}$ : O sócio que for preso criminalmente, a Sociedade deverá tratar da maneira do seu livramento com a maior atividade possível, bem como lhe prestará uma quantia que o Conselho julgar conveniente durante sua prisão. Estes socorros lhes serão dados caso seja pobre, à requisição sua, e depois da informação do Filantropo de seu distrito, suspendendo-se-lhe todos os socorros logo que por sentença lhe for verificado o crime de furto.

Artigo $38^{\circ}$ : Se, porém, o crime for verificado, e pela reincidência no mesmo, ou noutro qualquer por mais de duas vezes, no mesmo ano, se conhecer que o sócio o costuma perpetrar por hábito, ou espírito de maldade, neste caso a sociedade não terá obrigação de o defender, porém o conselho lhe prestará os benefícios que julgar convenientes.

Nas leis da mesma associação podemos encontrar novas restrições disciplinares em consonância com o resguardo da moral e da ordem presentes na sociedade nacional, é o caso da recusa expressa de benefícios às viúvas ou filhas órfãs que se entregarem à prática da prostituição. Da mesma maneira que a representação corrente sobre a periculosidade do homem das classes populares era materializada no furto, forma comum de ataque à propriedade, percebemos que a representação da mulher das classes populares estava na ameaça à "família" à "moral” e "aos bons costumes" concebida na figura da prostituta.

\section{4- Indícios de práticas democráticas}

Apesar dos limites acima expostos à participação nas associações, elas representaram muito

representante. A Casa dos Marceneiros e dos Carpinteiros proibia os sentimentos desleais e as canções políticas. (...) Considerados em conjunto, eles [sindicatos e clubes de trabalhadores] indicam a aquisição de autodisciplina e a difusão de experiências, num grau impressionante" (THOMPSON, 2002). 
mais um movimento de abertura da ação política às classes subalternizadas da sociedade. Prova disso estava na determinação presente em quase todos os estatutos: "a sociedade é composta por ilimitado número de sócios..." e nos baixos valores de joias de entrada, subscrições ou mensalidades, situações também encontradas por Thompson (2004) nos estudos sobre a formação da classe operária inglesa. Para ele, esta era uma das características que permitiam identificar uma “organização operária", e entre os anos de 1790 a 1850 significou o término das noções de exclusividade e de política como reserva de uma elite hereditária ou de um grupo proprietário.

Eis o trabalhador como secretário. Eis a baixa subscrição semanal. Eis o entrecruzamento de temas políticos e econômicos. Eis a função da reunião tanto como ocasião social quanto centro para a atividade política. Eis a atenção realista para as formalidades de procedimento. Eis, acima de tudo, a determinação de propagar opiniões e de organizar os adeptos, contida na diretriz: "Que o número de nossos membros seja ilimitado". (...) Abrir as portas à propaganda e à agitação dessa forma "ilimitada", implicava numa nova noção de democracia que punha de lado as velhas inibições e confiava nos processos de auto-ativação e auto-organização da gente simples (THOMPSON, 2004, p. 20).

A relevância do papel da assembleia geral que funcionava como espaço democratização de informações e tomada de decisões fundamentais: política de finanças, reformas de estatutos, bem como quaisquer assuntos para os quais fosse convocada pelo conselho60 fundamenta a afirmação que a gestão dessas associações destoava da macropolítica imperial que punha a margem a maioria daqueles que eram os "sócios comuns" dessas entidades, fosse pelo critério de renda, ou pelo critério de alfabetização estabelecido com a reforma eleitoral de 1881.

No item "Patrimônio" do relatório da Protetora dos Artistas Sapateiros e Classes Correlativas é apresentada a quantia em caixa de 3:038\$874 e em seguida a afirmação de que "a assembleia geral ordenará a sua colocação mais acertada”. A assembleia também era espaço de regulação da gestão em vigor por análise de seus relatórios e balanços que prestavam contas por ocasião do seu encerramento, além de deliberar sobre reformas nos estatutos. É difícil dizer qual o uso feito pelos sócios comuns de tais informações, ou qual seu grau de ingerência sobre o destino desses fundos, cabe salientar que faz diferença, para a possibilidade de uma prática democrática, a disponibilização desses dados num fórum coletivo.

60 Art 20: Compete à Assembleia Geral: $\S 1^{\circ}$ : Ouvir e examinar o relatório dos trabalhos do Conselho que finda, e o balanço geral da receita e despesa que este lhe apresentar, tomando a este respeito, todas as medidas necessárias a bem da Sociedade, sempre em observância dos estatutos.

$\S 2^{\text {o: }}$ Aproveitar ou rejeitar em todo, ou em parte, e de modo prescrito nos estatutos a reforma ou modificação dos mesmos, proposta pelo conselho.

$\S 3^{\circ}$ : Resolver todas as proposições feitas pelo conselho, quando por este convocada ou consultada. (Estatutos da Auxiliadora das Artes e Ofícios e Beneficente dos Sócios e de Suas Famílias) 
Todos os cargos das direções, conselhos e comissões eram exercidos por sócios. No caso da Auxiliadora das Artes e Ofícios e Beneficente dos Sócios e de Suas Famílias, o artigo sétimo indicava que "o conselho é composto de 31 membros, eleito pelos sócios em colégio eleitoral, de seis em seis meses”. Nesta mesma entidade, todo sócio podia votar, mesmo os ausentes podiam enviar suas cédulas assinadas e fechadas ao colégio eleitoral. Ainda após a transmutação desta associação para Imperial Sociedade Auxiliadora das Artes Mecânicas e Liberais e Beneficente sua diretoria demonstra perfeito conhecimento de exercer um mandato submetido aos mandatários: os sócios, operários, que poderiam julgar se "a gerência da associação, respeitou e fez observar todas as disposições de nossa lei orgânica; manteve ilesos os direitos e deveres dos sócios, e aumentou os capitais dos cofres, limitando as despesas às proporções legais”.

Além de democráticas estavam previstas também práticas de direitos. No que diz respeito aos empregados das associações, todos os estatutos apresentam a disposição de caso houvesse um processo de demissão, abrir espaço para a defesa do funcionário em questão. No parágrafo terceiro do artigo décimo dos estatutos da Sociedade Auxiliadora das Artes e Ofícios e Beneficente dos Sócios e Suas Famílias estabelece-se que: “Compete ao Conselho: suspender a todos os empregados em geral e demitir unicamente os de sua nomeação: tudo por causa motivada e depois de ouvidos os acusados". E quanto aos sócios: "assim como todos aqueles que não o sendo, estiverem a serviço da sociedade, podem reclamar seus direitos perante o conselho". Aos sócios desta entidade estava previsto ainda o direito de formular propostas e defendê-las junto ao conselho. Segundo os estatutos "todo conselheiro tem direito de propor ao Conselho medidas que sejam úteis à Sociedade". Mas, vai além:

Em geral, todo sócio pode propor ao conselho, medidas em benefício da Sociedade, e terá assento no Conselho em lugar separado na ocasião em que se discutir sua proposta e então gozará de todas as prerrogativas concedidas aos conselheiros, aos quais, todavia é privativo o direito de votar, devendo ele retirar-se do círculo do Conselho logo que se conclua a discussão.

Reconhecendo as "inovações" na cultura política vigente própria do Antigo Regime, é importante salientarmos que essas organizações eram sujeitos de seu tempo e tanto democracia como direitos tinham limites em seu interior. As próprias assembleias realizavam-se, em quase todos os casos, uma ou duas vezes ao ano, em geral nas datas de aniversário de fundação das associações, quando também se encerravam gestões das diretorias. Em todo o restante do tempo, eram os conselhos diretores que dirigiam as entidades. Mas, outros limites mais explícitos interpunham-se a democracia. O próprio voto era restringido de diferentes formas nas associações e tanto a presença como a participação de mulheres era reduzidíssima. A Sociedade União Beneficente Niteroiense é uma das poucas onde encontramos maior expressividade da presença 
feminina. Nos anexos entre os muitos nomes de sócios que ali aparecem, encontramos de 10 a 15 mulheres, ao que parece, em geral, fazem parte de casais que se associavam juntos (marido e mulher). Entre os sócios que têm direito ao título de benfeitor encontramos duas mulheres: Anna Luiza do Coração de Jesus e Maria da Glória e Silva.

Havia mais ou menos um padrão para a restrição de votos, como também observamos haver para as penalidades e perdas de direitos. Constituía este padrão elementos como não estar quite com suas mensalidades ou estar preso. Entretanto, não raro, encontramos restrições ao voto feminino nas associações que aceitavam mulheres. O Congresso de Beneficência e Instrução, antigo Operário de Beneficência, determinava em seus estatutos que "as sócias maiores de 18 anos poderão votar mas não ser votadas para os cargos administrativos do Congresso". Surpresa maior foi, porém, encontrar em algumas associações a restrição ao voto de analfabetos antes mesmo da reforma eleitoral, como na Sociedade de Beneficência dos Artistas da Construção Naval, cuja reforma dos estatutos impondo tal limite foi submetida ao Conselho de Estado em 1879.

Seguindo a mesma lógica, vemos os estatutos da Sociedade Concórdia Beneficente Vinte e Oito de Abril estabelecerem em seu artigo onze que "Todo sócio tem direito a votar e ser votado excetuando-se: 1- Os menores de 21 anos e os que não souberem ler e escrever que poderão votar, mas não ser votados; 2- Os que não estiverem quites de suas contribuições, ausentes, ainda que com participação, e os que residirem fora de Niterói; 3- Os que estiverem presos ou pronunciados; Os do sexo feminino". Vemos somarem-se a reprodução de antigos preconceitos difundidos por uma sociedade de origem patriarcal que vedava a cidadania ativa às mulheres com novos preconceitos contra aqueles que não sabiam ler e escrever, parte do processo de construção do analfabeto como sujeito ignorante, incapaz politicamente como alguém que não tivesse atingido a maturidade.

As limitações prescritas na legislação podiam ser surpreendidas por ações imprevistas dos sócios, como pode ser constatado no relatório da Sociedade União Beneficente Niteroiense, que registra, no ano de 1885, a organização dos sócios para revogar uma decisão do conselho. "A quinta sessão efetuou-se em 23 de agosto em virtude de requerimento assinado por vários associados, no qual protestavam fazendo um apelo a mesma assembleia, contra o ato do conselho que eliminara do grêmio social a $\mathrm{Sr}^{\mathrm{a}} \mathrm{D}$. Herculana da Silva Nunes, por achar-se em débito das suas mensalidades. Essa assembleia em sua sabedoria entendeu destruir o ato do conselho". Dessa forma, entre interesses comuns e situações conflituosas, entre desacordos e consensos era tecido o "aprendizado da política" entre as classes trabalhadoras do Rio de Janeiro oitocentista. Tais diversidades e divergências serão abordadas no item a seguir.

\section{5- Diversidade e estratificação das organizações de trabalhadores e nas organizações de}




\section{trabalhadores}

Era comum encontrar, até fins do século XIX, organizações mutualistas e beneficentes de seus sócios que agregavam sujeitos de diferentes status sociais relacionados ou não aos ofícios ali representados. Por vezes, as compunham juntos mestres em determinada arte e operários contratados para executá-las. Ou donos de pequeno comércio, ao lado de caixeiros e guarda livros, em suma, trabalhadores assalariados. Sócios mais ou menos empobrecidos e os ilustres aceitos como beneméritos e bem feitores em condições diversas daqueles "sócios comuns".

O caso dos caixeiros tratado por Popinigis (1999) é bastante ilustrativo. Segundo a autora, havia diferentes tipos de caixeiros, organizados hierarquicamente de acordo com a função que desempenhavam (caixeiro de balcão, de fora, o vassoura, o guarda livros). Geralmente trazidos de Portugal, eles viviam o mundo ideológico dos patrões. Sonhando em ter seu próprio negócio, tinham-lhes fidelidade. A sociedade caixeiral da qual os estatutos foram aqui analisados previa a possibilidade de mudança de "condição ou posição social ou comercial" dos sócios, legislando o artigo quarenta e cinco que mesmo ocorrendo tais mudanças "os sócios uma vez admitidos, não perderiam seus direitos". Ou seja, aqueles que ascendessem socialmente, tornando-se proprietários, poderiam continuar associados na mesma entidade. Mas isso não apagava a situação de conflito de classes. Fabiane Popinigis aborda esta tensão ao discutir o movimento pela redução da jornada de trabalho nos estabelecimentos comerciais, conhecido como movimento pelo fechamento das portas no Rio de Janeiro em fins do século XIX.

Em Trabalho Lar e Botequim, Sidney Chalhoub salienta, antes das diferenciações e conflitos nos processos organizativos, as rixas envolvendo trabalhadores por questões de trabalho e habitação, ou na hora do lazer e do amor. Para o autor, "existem facções dos mais diferentes tipos entre qualquer grupo humano", isso implicaria "uma permanente possibilidade de confrontos a partir das tensões e divergências entre as facções. No nível da sociedade mais ampla essas tensões são expressas nas lutas de linhagens, de classes, etc. Mas essas tensões e lutas aparecem, também, em situações microscópicas do social, como nos grupos de trabalho, de vizinhança, na família, etc. De fato, uma verdadeira política do cotidiano". (CHALHOUB, 2001, p. 55 e 56). Cabe ressaltar, no caso da cidade do Rio de Janeiro, como bem mostra Chalhoub, as rivalidades étnicas, principalmente entre negros e portugueses. Estes últimos acabavam por encontra maior amparo na ordem instituída.

É essa diversidade interna às classes trabalhadoras que faz com que Batalha (2004) adote termo "culturas de classe" no plural. O papel da classe, no conjunto de estudos de uma nova história social do trabalho é problematizado, mas não negligenciado. Nesse sentido é que afirma que “divisão e unidade coabitam a classe, não se excluem, e a análise da relação entre os dois aspectos 
deve ser sempre contextualizada e submetida à lógica da mudança histórica” (BATALHA, 2004, p. 15). O mesmo autor nos informa que:

Os conceitos de classe e cultura operários têm sido submetidos a forte exame crítico, sobretudo por pressuporem, na visão de alguns, a existência de comunidades de sentido integradas e culturalmente estáveis. A ênfase nas relações de produção, no processo e mercado de trabalho, como elementos estruturantes da coesão política dos trabalhadores, fez com que, por muito tempo, o acento recaísse nas lutas, nas formas de organização e nos movimentos políticos. Ao enfocar o ativismo e a consciência de classe, os estudos tenderam a idealizar as comunidades operárias, concebendo-as como coletividades relativamente indiferenciadas e homogêneas, enquanto subestimavam os aspectos que indicavam dispersão e variabilidade de referências e comportamentos sociais (BATALHA, 2004, p. 12 e 13).

As associações de trabalhadores da segunda metade do século XIX em diante eram organizações de amplo recrutamento e, em geral procuravam deixar explícito o interesse de agregação entre três dimensões que costumavam dividir a classe: distinção de sexo, cor e nacionalidade (em alguns casos cita-se também credo religioso). Mas a aceitação desse amplo ingresso não significa que no interior das organizações não houvesse distinção desses membros. É o caso da Sociedade Concórdia Beneficente Vinte e Oito de Abril que se dividia em cinco classes de sócios, uma delas era separada para as sócias do sexo feminino: "A primeira dos fundadores; a segunda dos instaladores; a terceira dos efetivos ou contribuintes; a quarta, do sexo feminino; a quinta dos beneméritos e benfeitores" ${ }^{\prime 61}$. De acordo com a lei que regulamentava as associações, não era permitido escravos se associarem, logo, vários estatutos vedavam sua participação, porém havia alguns de caráter ainda mais excludente, como o da Sociedade União Beneficente Vinte e Nove de Julho onde se estabelece que "para ser sócio dessa sociedade é preciso: ser de condição livre e não ser de cor preta".

No que diz respeito às relações interclassistas no interior das associações de beneficência e auxílio mútuo, temos o caso exemplar da Imperial Sociedade Auxiliadora das Artes Mecânicas e Liberais, em seu relatório apresentado à assembleia geral no ano de 1864. Naquele ano havia sido promovido evento para angariar fundos para a sociedade. Houve uma subscrição entre membros do conselho e os sócios para as despesas com o evento, mas o registro remetido à assembleia enaltece em destaque um dos sócios beneméritos com tom e termos que não caracterizam uma relação entre iguais.

Com todo prazer vos cientificamos que se reverteu a favor da caixa acima 
referida, um saldo tão elevado, foi ele devido ao valioso donativo feito pelo muito digno sócio benemérito Sr. José Duarte Fonseca e Silva que espontaneamente ofereceu toda cera que foi precisa para a cerimônia, patenteando, com tanta generosidade, que é dotado de um grande coração, e o quanto é útil em nossa sociedade ter em seu grêmio um varão tão bondoso o qual é muito digno de nossa gratidão.

Segundo Batalha (2009) a citada associação teria surgido de uma reunião de artistas como Sociedade Auxiliadora das Artes e Beneficente dos Sócios e Suas Famílias, cujos estatutos também analisamos aqui. Em 1840 a sociedade adotara o nome de Auxiliadora das Artes Mecânicas e Liberais como resultado da fusão com a Sociedade Mecânica, recebendo em 1848 o título de Imperial. "Em maio de 1877, época em que surgiram divergências entre os sócios em torno de uma reforma dos estatutos, sua composição original foi inteiramente alterada, admitindo comerciantes, capitalistas e até negreiros" (BATALHA, 2009). Se no ano de 1877 é notada uma mudança radical na constituição da sociedade, já vemos no relatório de 1864 indícios das relações paternalistas fundamentadas em práticas caritativas e da estratificação entre sócios. Constatamos que honorários e beneméritos possuíam, em geral, títulos de nobreza como Visconde de Albuquerque, Comendador Antonio Fernandes Vaz, etc. Junte-se ainda a informação sobre sócios que adoeceram, mas dispensaram "os recursos que lhes seriam garantidos" - objetivo principal para o qual se ingressava numa associação de auxílios mútuos - marcando as diferenças de condições financeiras entre os sócios. Outro dado que reforça esta interpretação é o da proposta do sócio conselheiro da Auxiliadora das Artes Mecânicas e Liberais e Beneficente, Dr. Antonio José de Souza Rego, de criação de aulas de latim e francês para os filhos dos membros, recusada com o argumento das grandes despesas que iria acarretar. Fato que nos leva a questionar que sócios considerariam necessária a instituição destas aulas e quais poderiam, ou deveriam prescindir disso.

Além de heterogeneidade alguns documentos nos deixam perceber possíveis divergências internas. A leitura do relatório da Imperial Sociedade Auxiliadora das Artes Mecânicas e Liberais e Beneficente aponta para um conflito entre o caráter de auxílio mútuo e o de beneficência no momento em que, comemorando o sucesso da caixa para o estabelecimento pio (espécie de asilo que acolheria órfãos, enfermos, etc.), remete-se ao "espírito malévolo daqueles que muitas vezes diziam que esta caixa não passaria de uma ficção". A conclusão do relatório de 1863/64 transparece uma tensão quanto a aprovação dos atos do conselho.

Quanto aos atos do conselho a quem incumbiste de cultivar essa frondosa árvore de beneficência, plantada no íntimo de nossos corações, de colher tão melífluos e grandiosos frutos e distribuí-los por aqueles que se abrigam à sua sombra, se não corresponderam à vossa expectativa, cobrai-a como julgadores convenientes! Fazei justiça se erramos! Porém ficai certos de que 
se assim procedemos, foi involuntariamente, pois jamais nos dominou outro desejo que não fosse o de promover o engrandecimento de nossa Sociedade! Jamais nos dominou outro desejo que não fosse o de denodado, com valor, sustermos o nosso grande estandarte, o qual, graças ao criador, às Suas Majestades Imperiais, nossos augustos protetores e a vós outros, vai tremulando ao sopro do mais propício favonio pela senda do progresso social!

Tensões assim poderiam levar a embates mais diretos já prevenidos por alguns estatutos. Nenhuma lei prescreve medidas para algo que não esteja na realidade de determinada coletividade. Se virmos a regulação e penalidade para caso de "distúrbios que perturbem a ordem dos trabalhos", como no caso do Congresso de Beneficência e Instrução, cuja pena seria admoestação pela primeira vez e a suspensão de direitos sociais no período da reunião, isso indica que as divergências internas poderiam ser levadas ao limite dos consensos estabelecidos. Interessa aqui salientar tais "distúrbios" como possíveis meios de participação não autorizados pelos estatutos, passos também significativos no aprendizado da prática democrática pelo qual acreditamos que em tais entidades educava-se e formava-se a classe.

Além das diferenças "nas" associações havia diversidade e divergências "entre" elas. Um dos motivos de disputa dizia respeito à busca de recursos financeiros junto ao Estado, geralmente sob a forma de extração de loterias. A prioridade de cada associação na extração de loterias demonstra também uma hierarquia entre elas.

Não obstante ter S. M. Imperial, que tanto tem cooperado para a prosperidade de nossa sociedade, ordenando que se extraísse no ano próximo passado a terceira loteria, não foi possível em razão de não ter se extraído as que estavam designadas antes da nossa, mas tendo o conselho exuberado todos os esforços, conseguiu que ela fosse inserida no quadro organizado pelo governo, por isso podemos nutrir a esperança de que seja extraída até junho a terceira loteria confirmada por decreto n. 3203, de 24 d dezembro de 1863, graças à S. M. Imperial, nosso magnânimo protetor (Relatório da Imperial Sociedade Auxiliadora das Artes Mecânicas e Beneficente).

Novamente o trabalho de Popinigis sobre os caixeiros nos ajuda a compreender os conflitos entre associações. A autora encontra no jornal $O$ País, uma enquete cujo resultado mostrava que a Associação dos Empregados do Comércio não vinha protegendo os caixeiros. "Segundo os entrevistados, o fausto palaciano da associação teria afastado os mais humildes, que não se atreviam a estar entre os casacas, muitos não confiavam na associação por ali estarem também os patrões. Consoante um deles, 'ao lado do patrão, só no balcão'. E por isso, organizavam-se outras entidades de classe, das quais apenas caixeiros pudessem fazer parte, e nas quais não permaneciam aqueles 
que se tornassem patrões" (POPINIGIS, 1999, p. 118).

Destoando de todas as associações aqui estudadas encontramos a Sociedade Protetora dos Empregados Públicos. Nela também estava bem clara a estratificação entre altos e baixos cargos públicos daqueles que a associação pretendia agregar, inclusive com diferenças de contribuições e benefícios. Como mostra da diversidade no universo das associações promovidas por trabalhadores, temos nos estatutos da Sociedade Protetora dos Empregados Públicos algumas dissonâncias cruciais em relação às associações de artistas embora seus fins fossem bem próximos aos de outras associações62, uma vez que, pela sua alegação, não tinham do Estado garantias trabalhistas. É preciso notar, primeiro, que havia grande estratificação entre os empregados públicos. Na exposição "Das vantagens da Sociedade Protetora dos Empregados Públicos e análise demonstrativa e comparativa de seu movimento social" o relator diferencia os pequenos e altos funcionários do Estado, todos ligados pelo fato de não terem outros recursos que não “os seus vencimentos".

No civil, não só os pequenos empregados, mas também os altos funcionários do Estado, se não tem outros recursos além dos seus vencimentos, não poucas vezes deixam suas famílias com deficiências de meios para manterse em medíocre abastança.

Há funcionários que não têm vencimentos, e que embora tenham prestado serviços ao Estado, com a criação de um simples montepio, não poderiam curar do futuro da família.

Os operários dos diversos estabelecimentos públicos, depois de longos anos de trabalho, sem direito à aposentadoria e menos a estabelecer montepio para suas famílias, por sua morte elas ficarão de braços com a miséria.

$\mathrm{Na}$ classe militar, o oficial do exército deixa a metade do seu soldo e o oficial da armada, por meio de montepio, igualmente deixa o equivalente a meio soldo à família. Hoje, este meio soldo não é o suficiente para o necessário de mulher e filhos.

É possível ver uma ênfase maior que de outras sociedades, nas pensões aos empregados aposentados e às suas famílias, às quais marcam como valor "a metade de seus vencimentos". Outras importantes diferenças dizem respeito ao seu vulto e valor de sua joia de entrada e mensalidades. A Sociedade atendia a todo o Império, possuía empregados e escritórios em diferentes localidades do Brasil. As contribuições dos sócios eram consideravelmente mais altas se comparadas às associações de artistas. Os sócios eram divididos em primeira, segunda, terceira e quarta classes, de acordo com as quantias pagas, as quais regulariam proporcionalmente as pensões

62 Art. $2^{\circ}$. Esta sociedade tem por fins:

$\S 1^{\circ}$. Assegurar o futuro dos empregados públicos e de suas famílias, pela instituição de pensões vitalícias equivalentes a metade de seus vencimentos.

$\S 2^{\circ}$. Assegurar meios de subsistência aos empregados públicos que perderem seus lugares por motivos não desonrosos.

$\S 3^{\circ}$. Socorrer aos empregados públicos que por moléstia e durante ela perdem os seus vencimentos.

$\S 4^{\circ}$. Fazer funerais aos sócios que morrerem na indigência. 
a serem recebidas.

Podem, igualmente, ser membros da associação, todos os altos funcionários públicos e os empregados de qualquer categoria de todas as repartições ou ministérios, em exercício ou aposentados; os membros de magistratura em todas as classes ou categorias, os escrivães, tabeliães e todos os outros empregados forenses, os empregados das municipalidades, até os guardas fiscais, os empregados de polícia, desde os chefes de polícia, delegados, subdelegados, suplentes de um e outro, escrivães e até os inspetores de quarteirão, os empregados eclesiásticos desde os prelados, corpo eclesiástico do exército e armada, cônegos e outros e outros empregados das Sés episcopais, até os vigários e coadjutores, os professores e professoras da instrução primária e secundária, os lentes e demais empregados das academias e mais escolas do Estado. Os empregados das vias férreas do governo, os médicos e farmacêuticos do exército e da armada, ou empregados pelo governo em qualquer comissão, os enfermeiros e mais empregados dos hospitais miliares ou de outros estabelecimentos sanitários do governo, os empregados do corpo diplomático, residentes em país estrangeiro, os empregados exercendo simples comissões do governo: finalmente os empregados dos arsenais, casa da moeda, tipografia nacional, e outros estabelecimentos do Estado.

Ora, todos os indivíduos compreendidos em qualquer das classes e categorias acima indicadas podem inscrever-se na sociedade com quantias correspondentes a formarem para si e suas famílias as pensões que lhes aprouver.

Esta ambiciosa empresa tinha como garantia o nome de seu presidente Sua Excelência o Visconde de Inhomirim. Projetava um alto número de sócios - vinte mil inscritos num período de cinco anos, que se assim permanecesse por trinta anos renderia um capital de 85.497:545\$874, com a despesa de 8.586:680\$000 o que equivaleria a nove por cento sobre o fundo social. Grande negócio... Ainda porque não contavam com um perfil de sócio pobre, que exigisse socorros frequentes.

Quanto ao socorro dos sócios desempregados e enfermos, a pouco podem montar, não só porque não avultam os casos em que podem ter lugar, como porque segundo a prática demonstra, não será longo o tempo que os socorridos deles carecerão.

Note-se também que os sócios socorridos não prejudicam a sociedade, porque não só perdem o tempo que não podem entrar com a mensalidade, o qual não lhes é contado para o tempo das pensões, suas ou da família, como ainda terão de entrar oportunamente, no tempo marcado nos estatutos, com as mensalidades atrasadas.

Quanto aos funerais, estes a pouco montão, e o seu número não pode ser grande, visto que só são feitos aos sócios que falecem na indigência.

Ao nos aproximarmos primeiras décadas do século XX e daí em diante, mesmo sem perder o caráter mutualista, vemos cada vez mais o crescimento das associações chamadas "de classe" que apresentavam menor grau de estratificação social interna. Entretanto, já é possível encontrar tais 
associações durante o século XIX, como é o caso da Sociedade de Socorros Mútuos Protetora dos Artistas Sapateiros e Classes Correlativas. Em seu relatório do ano social de 1885 a 1886, não consta entre os quadros de sua diretoria nenhum título de Doutor, Comendador, qualquer título de nobreza ou patente militar. Também entre seus beneméritos não constam tais distintivos. A conquista das benemerências na Sociedade dos Sapateiros se dava por outras vias que não as doações em somas em dinheiro ou bens, ainda que estas também existissem. A via principal era a prestação de serviços, ou seja, a participação na administração da própria associação, como o próprio relatório registra: “Continuam como cobrador e escriturário, o sócio benfeitor Urbano José Ferreira e escriturário, o sócio benemérito graduado Hermenegildo Damásio Lourenço da Silva; vede senhores sócios, que ninguém conquista um título sem prestar serviços”. Logo a seguir, na divulgação das benemerências, encontramos oito agraciados por terem servido, cada um deles, por três anos consecutivos no conselho. Ou seja, as posições de benemérito ou bem feitor, expressas pelas mesmas palavras, poderiam ter significados diferentes para diferentes associações no momento estudado - ser o portador de tal título numa associação de classe não seria o mesmo que o ser em uma sociedade caritativa, instrutiva ${ }^{63}$. Códigos de uma cultura mutualista, ou mais adequadamente de "culturas" no plural, assunto do tópico que se segue.

\section{6- Relações entre sociedades e cultura mutualista}

As sociedades de auxílio mútuo, por existirem em muitas comunidades diferentes, representavam uma influência cultural unificada (THOMPSON, 2002). A diversidade de experiências anteriormente comentada não se opõe ao que Batalha (2004) classifica como "cultura associativa" portadora de um duplo significado. O primeiro como "hábito de associar-se" conferindo institucionalidade a formas de sociabilidade diversas. O outro significado é de cultura das associações. "Por cultura entende-se não apenas a produção cultural, no sentido de peças de teatro, conferências, música, mas as celebrações, os costumes, as normas que regiam as associações operárias. Em outras palavras, como através dessas práticas e desses rituais os membros das associações percebiam o mundo e a si mesmos" (BATALHA, 2004, p. 96 e 97).

Foi possível até aqui detectar algumas expressões desta cultura mutualista como a importância atribuída às relações entre Sociedades. Quase todos os estatutos e relatórios pesquisados, principalmente os de associações de artistas, prescrevem ou fazem referência à ligação

63 No estudo sobre as escolas noturnas para trabalhadores no Município da Corte durante a segunda metade do século XIX que desenvolvi no mestrado (COSTA, 2007), encontrei a figura do benemérito em associações civis promotoras de tais escolas como o homem de elite que procurava, de forma condescendente, "civilizar o povo" por meio da instrução. 
com outras entidades de interesses e objetivos semelhantes. Era comum delegações destas chamadas Sociedades "coirmãs" estarem presentes em eventos como tomada de posse de diretorias, missas encomendadas, inaugurações, eventos para levantamento de fundos, etc., como mostra o trecho do relatório abaixo.

Concluindo, Senhores, agradeço do fundo d'alma àqueles companheiros que tão bem souberam representar a sociedade perante às nossas co-irmãs, dando provas de que a Sociedade de Socorros Mútuos Protetora dos Artistas Sapateiros e Classes Correlativas existe a boa ordem e a união fraternal, que é a base de todas as associações.

Nesse mesmo registro parecia haver uma rede de informação entre as associações que ia além daquelas obtidas durante a presença de delegações de umas sociedades convidadas a participar de eventos e solenidades promovidos pelas outras. Havia o hábito do envio de correspondências e materiais ordinários entre as chamadas coirmãs, como consta no Relatório da Sociedade União Beneficente Niteroiense agradecendo por:

Ofício da Sociedade Amparo Operário, capeando a relação dos membros da administração que tem de servir no exercício de 1885 a 1886. Relatório da Sociedade Concórdia Beneficente Vinte e Oito de Abril. Ofício do secretário da Associação dos Empregados do Comércio do Rio de Janeiro, apresentando a relação da administração que tem de gerir essa associação durante o exercício de 1885 a 1886. Relatório da Associação Beneficente da Colônia Portuguesa. Em 26 de dezembro foi recebida a nominata dos membros da administração da S. M. Memória a Santa Izabel, rainha de Portugal. Relatório da Sociedade Beneficente Amparo do Operariado.

O universo ritualizado e simbólico das associações gerava coesão interna e "davam ao público externo impressão de coesão e unidade" (BATALHA, 2004, p.103). Usava-se e abusava-se do simbolismo para garantir a coesão e a identidade entre as associações de trabalhadores. No relatório da Sociedade dos Sapateiros e Classes Correlativas encontramos entre as "ofertas e donativos" dos sócios: "De João Rebelo Gonçalves, um quadro com a opinião da imprensa sobre nossa posse; de João Antonio Lopes Marinho, vinte e uma encadernações dos estatutos com dísticos dourados; de Antonio dos Santos Vieira, o retrato a óleo do nosso digno presidente". Na construção dessa identidade que se fazia para dentro, mas também para fora da sociedade, a relação com a imprensa era de fundamental importância, tanto que algumas delas procurarão editar seus próprios jornais, como veremos no capítulo seguinte.

Os órgãos da imprensa eram também forma de comunicação entre sociedades e entre sócios, como vemos no estatuto da Sociedade Socorros Mútuos Montepio dos Conservadores em seu artigo noventa e dois: "Logo que houver mais de 3 sócios falecidos o conselho mandará rezar uma missa no dia 2 de novembro pelas almas dos sócios falecidos, convidando pela imprensa todos os sócios para assistir a esse ato de religião". Convocação que nos mostra que além dos auxílios materiais, 
tinham importância os auxílios morais e espirituais como as missas mandadas rezar por alma de associados falecidos, o acompanhamento de enterros de associados pelos demais membros, práticas que reforçavam a coesão e faziam parte de uma cultura dessa classe.

Outra forma prevista de manifestação dessa cultura era a centralidade dada ao aniversário das associações que procuravam "Solenizar anualmente com a possível pompa"64. Nestas solenidades os sócios deveriam, muitas vezes, usar paramentos especiais. No caso do Congresso de Beneficência e Instrução, uma medalha de ouro pendente de fita branca para os sócios de maiores títulos, para os demais, na casa da sobrecasaca, roseta formada de fitas nas cores sociais. Para as sócias, quem o estatuto afirma não ficarem excluídas, os distintivos, embora iguais os dos sócios deveriam ser sempre usados no lado esquerdo do peito. Os retratos de presidentes e benfeitores, quando possível, expostos em galeria, também eram símbolos valorizados. Essa simbologia aproximava organizações diversas. Na Sociedade Montepio dos Conservadores os sócios também faziam uso "no recinto ou em solenidades (...) de um distintivo colocado ao peito, do lado direito do fraque, o qual constará um pequeno laço de fitas seguro com alfinete ou grampo com a letra C". E, além disso, "na casa onde estiver funcionando a Sociedade, nos dias santificados e de sessão, será arvorada uma bandeira azul com um quadrângulo branco no centro, tendo sobre este um escudo vermelho com a letra C azul, adotada como emblema da sociedade".

Por fim importa ressaltar a questão simbólica da construção da imagem do trabalhador na qual participam as associações estudadas. Tanto o Estado imperial quanto o Estado republicano tinham um projeto de cidadão trabalhador tornado hegemônico após o fim da escravidão, que foi incorporado, de certa forma, pela própria classe organizada. Entretanto, é possível perceber na documentação investigada, um embate entre concepções e visões de mundo de Estado e trabalhadores, cenas de lutas simbólicas que aparecem nas formulações de estatutos e relatórios. No parecer do Conselho de Estado sobre os estatutos da Sociedade Beneficente dos Artistas e São Cristóvão pede-se “Acrescentar mais um parágrafo ao artigo $4^{\circ}$, declarando que os menores devem ser propostos por seus pais ou tutores, os quais se responsabilizarão por todas as obrigações pecuniárias do menor". E “Ao artigo 74, para que fique bem claro é compreender só as filhas e filhos legítimos como se deve supor que é a intenção”. Ainda, na Associação de Socorro Familiar Homenagem a Serpa Pinto indica-se que "No final do artigo dois deve acrescentar-se que os menores serão propostos por seus pais, tutores ou curadores, os quais serão responsáveis por todas as obrigações pecuniárias dos seus propostos". O que vemos são diferentes concepções de infância e família. Entre as classes trabalhadoras o universo da criança não se apartava do universo do adulto, dividindo os espaços, as responsabilidades, ambos inseridos no mundo do trabalho. Ao 
mesmo tempo, a família não era necessariamente regulada pela formalidade cristã e civil, podendo ser extensa e compreender e acolher como legítimos membros que para o Estado não o eram.

Chalhoub (2001) afirma que o projeto da República (com o início de gestação ainda no período imperial) para o homem livre pobre era transformá-lo em trabalhador, fonte de acumulação de capital. Exploração econômica vinculava-se, ou mesmo dependia de mudança espiritual. O Estado contou com o aparato policial que vigiava o trabalhador possível de ser rotulado como "vadio". A polícia visava todos os indivíduos que se encontrassem nos botequins e nas ruas e não tivessem como provar sua condição de trabalhadores. Podemos acrescentar à reflexão de Chalhoub o papel da própria educação escolar voltada ao trabalhador com o intuito de "reforma espiritual" desses sujeitos. Porém, havia na época, na cidade do Rio de Janeiro, uma cultura popular vigorosa e insubmissa que resistiu ao projeto dominante. Resistência esta que também se fez a partir da apropriação da imagem de trabalhador ideal veiculada pelas autoridades.

As associações de trabalhadores procuraram construir, dessa forma, a imagem do trabalhador com intuito de obter credibilidade e aceitação social em busca de melhores condições de vida. Alguns termos utilizados em estatutos e relatórios são bastante representativos: ao se referir ao enterro dos sócios da Sociedade Montepio dos Conservadores adota-se o predicado "simples, mas decente". Ao tratar da vida dos fundadores do Congresso de Beneficência e Instrução, fala-se de uma "existência trabalhadora e limpa". Esse discurso materializa-se na exigência para ingresso nas sociedades operárias de ser "bem morigerado". A todo o momento pretende-se mostrar o trabalho como forma de regenerar a "natureza" do sujeito trabalhador. As adversidades expostas em "trabalhador, mas descente"; "trabalhador, mas limpo"; "trabalhador, mas de boa moral", nos levam a crer numa estratégia de parcela organizada da classe em incorporar o discurso dominante para em seguida subvertê-lo.

\section{7- Práticas educacionais formativas entre a experiência e a escolarização}

Para captar as concepções educacionais próprias das classes populares e suas ações educacionais é necessário ir além da forma escolar. É com esse intuito que o presente trabalho considera a educação com um sentido mais amplo. Por isso se volta para a experiência nas práticas internas das associações sem deixar de estabelecer seus pontos de contato com os saberes escolarizados.

Leis escritas, atas, relatórios, vemos a estreita ligação dos sujeitos aqui caracterizados com o mundo da escrita e da leitura. Mesmo os que possivelmente não soubessem ler e escrever presenciavam e escutavam a leitura de relatórios e balanços de gestão em assembleia. No relatório sobre o ano de 1863/64 da Imperial Sociedade Auxiliadora das Artes Mecânicas Liberais e 
Beneficente identificamos o costume de ser apresentado pelo secretário o livro de atas das sessões do conselho nas solenidades de posse dos novos conselheiros. Nos estatutos da Sociedade Bem Estar dos Caixeiros estabelecia-se como um dos deveres dos sócios, "o tributo dos seus conhecimentos que deveriam ser dirigidos ao conselho, por escrito65, sob forma de quaisquer indicações das quais se possam tirar utilidade". A crença implícita aqui é aquela narrada por Thompson na história da formação da classe operária inglesa de que

"um homem é um homem, apesar de tudo". (...) Esperava-se que todo cidadão, num comitê, desempenhasse alguma tarefa, a presidência dos comitês geralmente era ocupada por rodízio; mantinha-se sob observação as pretensões dos líderes, os procedimentos baseavam-se na crença deliberada de que todo homem era capaz de raciocinar e de aumentar suas capacidades, e que a submissão e diferença de status eram um insulto à dignidade humana (THOMPSON, 2004, p. 202).

No desempenho das funções sociais, leitura, escrita e cálculo eram de grande importância, ao passo que organizavam, também humanizavam. As formalidades da escrita já estavam presentes na vida de um associado desde o seu ingresso, uma vez que, como consta nos estatutos da Auxiliadora das Artes e Ofícios e Beneficente dos Sócios e Suas Famílias e de outras entidades pesquisadas, ele deveria "apresentar ao conselho um requerimento em que declare seu nome, naturalidade, idade, estado civil, arte ou ofício que exerce, rua e número da casa". Mas, ser aceito em uma dessas organizações era só o início da vida associativa. No momento seguinte já se fazia necessário entrar em pleno contato com suas leis.

Os estatutos eram respeitados como a lei máxima das entidades, o que notamos nas frases de diversos relatórios como o da Protetora dos Artistas Sapateiros e Classes Correlativas - "sabemos observar tudo quanto nossa lei predisse e impôs" - nesse caso temos uma escrita organizadora da classe. Para além desse artefato mais cristalizado, permanente, em que pesem as reformas que volta e meia neles se faziam, a escrita e o cálculo são ferramentas organizativas de extrema importância no dia a dia das associações. Segundo o mesmo relatório, era "o cobrador quem [nivelava] os destinos de uma associação! [Era] o escriturário quem [garantia] o bem estar dos sócios pela fidelidade e clareza dos seus livros". Outras habilidades necessárias para a administração de uma associação expressam-se em alguns verbos presentes nos estatutos da Auxiliadora das Artes e Ofícios e Beneficente dos Sócios e Suas Famílias que apontam entre as funções do tesoureiro: “organizar a conta geral da receita e despesa da sociedade. (...) Apresentar mensalmente ao conselho uma demonstração da receita e da despesa. (...) Assistir às seções do conselho e opinar em qualquer matéria financeira, dando a este respeito, de vida voz ou por escrito, as informações que o conselho exigir... Habilidades estas que também se remeteriam ao plano coletivo, ao conjunto 
dos sócios reunidos em assembleia geral. De acordo com a lei da Associação Tipográfica Fluminense onde observamos no que compete à assembleia geral, verbos como: examinar se a associação tem sido bem administrada; tomar todas as medidas que julgar úteis à associação; resolver sobre acusações de infração dos estatutos; aprovar ou rejeitar as reformas dos estatutos propostas pelo conselho. Discutir, deliberar, aprovar, rejeitar, etc. Este conjunto de verbos que pode ser cotejado entre todas as sociedades aqui estudadas, se listados, nos darão notícia de uma intensa ação reflexiva no interior destas organizações.

O já citado histórico da Sociedade Auxiliadora das Artes Mecânicas Liberais e Beneficente por si só é um importante exemplo de esforço intelectual formalizado pela escrita no interior destas organizações. Além do fato representado pela própria iniciativa encontramos neste documento alguns termos indicativos das práticas de produção e transmissão de conhecimento. Antes de entrar nos relatos administrativos nosso "historiador" introduz a nova seção indicando que seria hora de "falar de nós [diretoria], de que havemos feito" e "de vós [os sócios]" e "[de suas] necessidades que o estudo e a experiência nos fizeram conhecer e de que vos daremos as convenientes explicações". Em seguida indica que ao longo do mandato, “Os atos praticados pelos que geriram os interesses sociais nos últimos anos passaram pelo cadinho da crítica, a mais severa, e ainda, na atualidade, sofrem a análise dos que os aplaudem ou rejeitam”. Possibilidade existente uma vez que “... Deus, ao mesmo homem deu a consciência". Vemos que estes homens estudam, aprendem com a experiência, dessa forma conhecem e explicam o que conhecem a outros os quais possuem, da mesma forma, capacidade de crítica e de análise usadas ao aprovarem ou rejeitarem o que lhes é apresentado: um exercício da consciência "dada por Deus" a todo homem.

A história era considerada uma fonte de aprendizagem, não necessariamente a História como disciplina, mas a memória das próprias organizações por um lado, e uma "grande história universal" a qual muitas vezes a intelectualidade anônima ligada aos periódicos e associações de trabalhadores recorria. Os quarenta e um anos de existência da Imperial Sociedade Auxiliadora das Artes Mecânicas e Liberais e Beneficente seria a matéria de conhecimento e fundamentação para os argumentos dos novos sócios.

Para corroborar o raciocínio temos a prova manifestamente verídica e irrecusável na própria Associação, que fundada no ano da graça de 1835, existe a 41 anos, robusta e florescente, prossegue impávida pela estrada do progresso que se lhe augura majestoso. Estudemos, pois, os acontecimentos e compulsando a tradição e ouvindo o testemunho dos que ainda vivem e foram os primeiros na organização, aproveitemo-nos da lição fecunda que a todos e a cada um de nós podem ministrar.

Não era uma prática rara, "estudar, compulsando a tradição e ouvindo o testemunho dos primeiros", verbos que se repetem em relatórios, estatutos e periódicos de mais de uma associação. 
A fonte e o momento dos estudos era a própria vida da entidade, a própria experiência dos sócios. $\mathrm{O}$ registro escrito de tais conhecimentos pela necessidade de relatar e analisar uma gestão administrativa não se opunha, antes, se alimentava do saber falar e escutar.

Pensando sobre as construções intelectuais citadas interrogo o que significava para os indivíduos ocuparem cargos nas diretorias das sociedades. A experiência na direção de uma Sociedade poderia ter forte resultado educativo para um trabalhador, em função do próprio esforço para elaborar e comunicar o pensamento, os cálculos para tomada de decisões envolvendo variáveis complexas presentes nos assuntos de interesse coletivo, até a própria necessidade de lidar com as técnicas veiculadas pela escola, principalmente a leitura e escrita. Mesmo para os que apenas votavam em seus "administradores" ou "diretores", número que não deve ser superestimado, uma vez que o funcionamento da associação contava com o serviço dos próprios sócios, não deixavam de refletir e avaliar os companheiros a serem eleitos, estavam imersos nesse jogo político. O que podemos afirmar com margem de segurança é que um trabalhador não seria o mesmo após a experiência associativa, ela era formativa, seria uma marca em sua trajetória e desse ponto de vista, educativa.

Ao questionarmos o presente corpus documental sobre a concepção educacional própria das classes populares tendo como pressuposto de serem estes sujeitos pensantes e ativos e não simplesmente "um problema" posto pelo projeto civilizatório do Estado nação brasileiro: "o problema da instrução do povo" ou "o problema do analfabeto" encontramos a valorização do mundo do conhecimento e das letras. Ao mesmo tempo vemos um movimento em busca da instrução formal como estratégia de acesso aos aspectos técnicos da leitura e da escrita. Saberes esses, necessários e úteis no cotidiano das classes populares, como mostram as práticas associativas.

Para alguns sujeitos o conhecimento adquirido da leitura e escrita podia ter papel vital. É o que conta a citada trajetória do sacerdote Domingos Africano na Bahia oitocentista contada por Reis. Já de início, durante o episódio da prisão de Domingos, vemos algumas mulheres africanas encontradas na mesma casa em que o sacerdote e também levadas à cadeia "defenderam-se muito bem, encabeçadas por Aniceta Rita Junqueira. No dia seguinte à prisão, escreveram petição ao Sr. Chefe de Polícia que explicava não passarem de honestas lavadeiras...” (REIS, 2008, p. 24). É o mesmo caso do escravo Florêncio em carta publicada no Correio Mercantil. Além de fazer uso da palavra escrita, compreende o papel da imprensa naquela sociedade e mobiliza tais recursos para protestar contra a retirada de um direito que considerava seu - fora alforriado, mas continuava a ser tratado como cativo. "O anúncio de sua liberdade, publicada por Florêncio, ao mesmo tempo em que traz um sentimento de subordinação a senhores legítimos e ilegítimos, constitui um protesto contra esses escravistas" (REIS, 2008, p. 63). 
Entretanto, não se tratava só da escrita como saber técnico e sim um "saber o que fazer com ela", que derivava da esperteza dos que precisam se adaptar às mais difíceis condições de vida. Tipo de experiência desvalorizada pela ordem vigente era frequentemente mal interpretada. Restituindo àqueles seres sociais a capacidade de pensar, a história contada por Reis opera algumas inversões. Primeiro, mostra que foram as autoridades baianas que não compreenderam os usos do candomblé. A preocupação dessa autoridade é que o candomblé do africano se transformasse numa organização subversiva que atuasse na promoção da revolta escrava. Porém a relação entre candomblé e resistência escrava seguia, sobretudo, outros caminhos. "A ideia de lançar mão de recursos rituais para controlar o poder senhorial, para 'amansar o senhor', por exemplo, tinha certa idade. (...) Para proteger duas escravas, suas clientes, do mau humor das respectivas senhoras (...) recomendou banhos com a infusão de certas folhas maceradas, um chocalho e dente de onça... Misturas domésticas para amolecer o coração de seus senhores" (REIS, 2008, p. 147 e 148). Segundo, aponta a influência dos rituais do candomblé sobre os brancos que procuravam seus serviços. Há registros, como o de Nina Rodrigues, da frequência de brancos e "pessoas de certa ordem" às reuniões do candomblé. O próprio Domingos também atenderia a brancos. "Seu envolvimento com gente engravatada, no entanto deve ser visto como uma conquista naquela sociedade que marginalizava sua crença. Ao assistir os 'civilizados' na solução de seus problemas, Domingos, de algum modo, escravizava suas mentes aos valores africanos" (REIS, 2008, p. 186).

Se a escrita era usada como ferramenta para sobrevivência das classes populares em contextos adversos, a oralidade mantinha seu peso cultural. Manoel Querino e Brás do Amaral falam da lisura dos compromissos firmados oralmente nas juntas de alforria, o não uso da lei e do contrato escrito, além de costume eram formas de impedir interferência dos senhores em seus negócios de compra de liberdade.

De acordo com Domingos Sodré, os membros da junta por não saberem ler se reuniam - se ajuntavam em assembleia para tomar decisões. E ali, a palavra acordada por todos tinha foro de contrato coletivo. Há, contudo, uma outra razão para que fosse assim, além da inexperiência africana com a escrita ocidental: os escravos não podiam contratar legalmente por si próprios daí serem sempre representados por curadores em questões judiciais. Essa era a lei do branco. Na lei dos pretos a palavra do africano valia. Havia interesse africano em que os dois universos continuassem separados porque isso impedia que os senhores metessem o vigilante nariz nos assuntos relacionadas à conquista da liberdade por seus escravos... (REIS, 2008, p. 211).

De acordo com o que tentamos mostrar ao longo deste capítulo, as associações pesquisadas também somavam saber de experiência, ligado ao cotidiano e à tradição, com a valorização da escolarização. Dessa forma, os estatutos da Sociedade Auxiliadora das Artes e Ofícios e Beneficente 
dos Sócios e Suas Famílias situam a instrução entre os meios de vida que deveriam ser providos aos órfãos dos sócios. Em seu artigo quarenta e sete a entidade estabelece: "Aos filhos órfãos menores de 15 anos, compreendidos no artigo quarenta e cinco, a sociedade promoverá a sua instrução primária e depois os fará aprender a aplicar a alguma ocupação, cessando de prestar-lhes os alimentos logo que por seus ganhos não precisarem". Tal artigo veicula ainda uma concepção de instrução, não como algo genérico, mas uma formação para o trabalho. Esta concepção também estava presente na Associação Tipográfica Fluminense cujos fins “... [cifravam-se] unicamente no desenvolvimento e progresso da arte tipográfica, na instrução artística, bem-estar e auxílio mútuo a cada um de seus membros e suas famílias”. Ou seja, a instrução era novamente posta lado a lado às necessidades de sobrevivência material, representadas pelo conteúdo dos auxílios mútuos, e configura-se não como qualquer instrução, uma instrução generalista, mas uma "instrução artística" emaranhada ao mundo do trabalho. Em todo caso, a valorização da cultura letrada é inegável. Ela seria mais que um aspecto utilitário, um traço de sua cultura de classe, uma vez que encontramos na cerimônia de posse das novas administrações que "terá lugar no aniversário da Associação, e os Conselheiros empossados brindarão nessa ocasião à Sociedade com uma obra manuscrita ou impressa para sua biblioteca", biblioteca esta composta "das ofertas de obras que lhe forem feitas e com as que o Conselho puder obter com os esforços que empregar".

Além desse esforço para desenvolver a arte tipográfica por meio de uma instrução artística, encontramos ainda outro processo de ensino aprendizagem, na linha da experiência ou vivência cotidiana. Trata-se de uma "educação dos costumes" aparente no artigo dezenove dos estatutos da associação onde se determina que "Se algum sócio se entregar à prática de más ações, o Conselho fará todo esforço para corrigi-lo, se o sócio, porém, durante o espaço de seis meses, não apresentar emenda em sua conduta, será desligado da Associação, o que terá lugar em Assembleia Geral”. Esse papel do Conselho "educador" também é encontrado em outras associações, como a Sociedade de Socorros Mútuos Montepio dos Conservadores que se dispõe a punir com a perda dos direitos sociais àqueles que "se entregarem à prática de maus costumes e que apesar dos esforços do conselho ${ }^{66}$ não apresentarem emenda em sua conduta no prazo de um ano".

Notamos entre os aprendizados amplos no interior das associações de trabalhadores o de normas e valores de convívio social, uma vez que, entre os motivos para a perda de direitos estava o de promover falsas acusações aos colegas motivadas por ódio ou vingança assim que comprovadas. Ou ainda, o de causarem "tumultos ou distúrbios no seio da sociedade de onde possa vir o descrédito e desmoralização". Mas também sofreriam suspensão os que fizessem maus usos dos poderes que lhes fossem confiados e os que "[injuriassem] qualquer membro da administração no 
desempenho de suas funções ou [agredissem e causassem ofensas físicas em qualquer pessoa seja sócio ou não". Seria um aprendizado do que os próprios estatutos chamam de "urbanidade" pela qual os sócios deveriam "portar-se com respeito quando acharem-se em reuniões ou em comissões da sociedade e tratar com delicadeza os sócios e suas famílias por mais pobres e humildes que sejam”. Entretanto, os mesmos estatutos nos informam sobre um aprendizado de subordinação aos superiores e autoridades constituídas. Segundo o artigo trinta e seis: "não se tolerará que qualquer associado, sejam quais forem os motivos, se insubordine ou falte ao devido respeito a seus superiores ou às autoridades legalmente constituídas. Logo que, com certeza, tão desagradáveis ocorrências chegarem ao conhecimento do conselho serão consideradas como faltas graves e dignas de serem punidas". Cabe pontuar que nem todo aprendizado é positivo e a palavra "experiência" não justifica qualquer tipo de prática.

As tabelas a seguir nos informam mais sobre as formas de ensino e aprendizagem levadas a cabo pelas associações estudadas.

Tabela 2: Práticas educacionais das associações atuantes de 1870 até 1889

\begin{tabular}{|c|c|c|c|c|}
\hline Nome & $\begin{array}{l}\text { Periódico/impres } \\
\text { so }\end{array}$ & Biblioteca & Instrução formal & $\begin{array}{l}\text { Conferências/exp } \\
\text { osições, etc. }\end{array}$ \\
\hline $\begin{array}{l}\text { 1- Associação de } \\
\text { Socorros Mútuos } \\
\text { "Liga Operária" }\end{array}$ & & & Oferecia "cursos" & $\begin{array}{l}\text { Conferências sobre } \\
\text { temas diversos }\end{array}$ \\
\hline $\begin{array}{l}\text { 2- Associação dos } \\
\text { Empregados do } \\
\text { Comércio no Rio } \\
\text { de Janeiro }\end{array}$ & & $\begin{array}{l}\text { Possui biblioteca } \\
\text { (em 1897, com } \\
6.000 \text { volumes) }\end{array}$ & $\begin{array}{l}\text { Ensino elementar; } \\
\text { Ensino de direito } \\
\text { comercial para } \\
\text { sócios; aulas de } \\
\text { línguas }\end{array}$ & $\begin{array}{l}\text { Conferências sobre } \\
\text { higiene e direito }\end{array}$ \\
\hline $\begin{array}{l}\text { 3- Associação } \\
\text { Nacional dos } \\
\text { Artistas } \\
\text { Brasileiros } \\
\text { Trabalho, União e } \\
\text { Moralidade }\end{array}$ & & $\begin{array}{l}\text { Intuito de manter } \\
\text { biblioteca }\end{array}$ & & $\begin{array}{l}\text { Intuito de } \\
\text { promover } \\
\text { exposições } \\
\text { artísticas e } \\
\text { industriais }\end{array}$ \\
\hline $\begin{array}{l}\text { 4- Associação } \\
\text { Tipográfica } \\
\text { Fluminense }\end{array}$ & O Tipógrafo & Possui biblioteca & Instrução artística & \\
\hline $\begin{array}{l}\text { 5- Clube dos } \\
\text { Libertos Contra a } \\
\text { Escravidão }\end{array}$ & Boletim do Clube & & $\begin{array}{l}\text { Cursos noturnos } \\
\text { de primeiras letras }\end{array}$ & $\begin{array}{l}\text { Realiza } \\
\text { conferências }\end{array}$ \\
\hline $\begin{array}{l}\text { 6- Congresso de } \\
\text { Beneficência e }\end{array}$ & & & $\begin{array}{l}\text { Curso teórico e } \\
\text { prático para }\end{array}$ & \\
\hline
\end{tabular}




\begin{tabular}{|c|c|c|}
\hline Instrução ${ }^{67}$ & & associados e filhos \\
\hline $\begin{array}{l}\text { 7- Imperial } \\
\text { Sociedade } \\
\text { Auxiliadora das } \\
\text { Artes Mecânicas e } \\
\text { Liberais }\end{array}$ & & $\begin{array}{l}\text { (Proposta de aulas } \\
\text { de francês e } \\
\text { latim68 }\end{array}$ \\
\hline $\begin{array}{l}\text { 8- Sociedade } \\
\text { Animadora da } \\
\text { Corporação dos } \\
\text { Ourives }\end{array}$ & $\begin{array}{l}\text { Compra de livros } \\
\text { de mecânica, } \\
\text { química, física e } \\
\text { metalurgia }\end{array}$ & Ensino do Ofício \\
\hline $\begin{array}{l}\text { 9- Sociedade } \\
\text { Beneficente } \\
\text { Filhos da Luz }\end{array}$ & $\begin{array}{l}\text { Intuito de } \\
\text { biblioteca (nos } \\
\text { estatutos) }\end{array}$ & $\begin{array}{l}\text { Intuito de escola } \\
\text { de ensino primário } \\
\text { (nos estatutos) }\end{array}$ \\
\hline $\begin{array}{l}\text { 10- Sociedade } \\
\text { Beneficente } \\
\text { Mútuo Progresso } \\
\text { do Engenho de } \\
\text { Dentro }\end{array}$ & & $\begin{array}{l}\text { Intuito de criar, } \\
\text { em tempo } \\
\text { oportuno, um } \\
\text { serviço de } \\
\text { instrução para } \\
\text { associados e seus } \\
\text { filhos }\end{array}$ \\
\hline $\begin{array}{l}\text { 11- Sociedade } \\
\text { Industrial de } \\
\text { Beneficência }\end{array}$ & & $\begin{array}{l}\text { Intuito de colégio } \\
\text { de instrução } \\
\text { primária e } \\
\text { secundária }^{69}\end{array}$ \\
\hline
\end{tabular}

Tabela 3: Práticas educacionais das associações fundadas a partir de 1890 até 1917

\begin{tabular}{|c|c|c|c|c|}
\hline Associação & Periódico & Biblioteca & Aulas & Conferências \\
\hline $\begin{array}{l}\text { 1- Associação } \\
\text { Beneficente do } \\
\text { Corpo de Oficiais } \\
\text { Inferiores da } \\
\text { Armada }\end{array}$ & & $\begin{array}{l}\text { Intuito de manter } \\
\text { biblioteca para } \\
\text { sócios }\end{array}$ & $\begin{array}{l}\text { Intuito de aulas } \\
\text { gratuitas de ensino } \\
\text { primário e } \\
\text { secundário e } \\
\text { cursos militares, } \\
\text { profissionais e de } \\
\text { educação física } \\
\text { para os } \\
\text { associados, seus } \\
\text { filhos e tutelados }\end{array}$ & \\
\hline
\end{tabular}

67 Antigo Congresso Operário de Beneficência.

68 A proposta foi recusada pelos sócios que consideraram a grande despesa advinda destas aulas para a Sociedade.

69 Era comum a intenção, expressa nos estatutos, de criar as escolas "quando fosse possível": "propõe igualmente criar um colégio de instrução primária e secundária para a educação gratuita dos filhos dos sócios pobres e por metade das pensões ordinárias para os sócios que tenham fortuna". 


\begin{tabular}{|c|c|c|c|c|}
\hline $\begin{array}{l}\text { 2- Associação de } \\
\text { Marinheiros e } \\
\text { Remadores }\end{array}$ & $\begin{array}{l}\text { Intuito de manter } \\
\text { uma revista oficial }\end{array}$ & $\begin{array}{l}\text { Intuito de manter } \\
\text { biblioteca e sala } \\
\text { de leitura }\end{array}$ & $\begin{array}{l}\text { Intuito de criar } \\
\text { aulas primárias e } \\
\text { profissionais para } \\
\text { associados }\end{array}$ & \\
\hline $\begin{array}{l}\text { 3- Associação de } \\
\text { Resistência dos } \\
\text { Cocheiros } \\
\text { Carroceiros e } \\
\text { Classes Anexas }\end{array}$ & $\begin{array}{l}\text { Intuito de jornal } \\
\text { de propaganda } \\
\text { (em estatutos de } \\
1922 \text { ) }\end{array}$ & & $\begin{array}{l}\text { Intuito de fundar } \\
\text { escolas para } \\
\text { associados e seus } \\
\text { filhos (em } \\
\text { estatutos de 1922) }\end{array}$ & \\
\hline $\begin{array}{l}\text { 4- Associação dos } \\
\text { Funcionários } \\
\text { Públicos Civis }\end{array}$ & & & $\begin{array}{l}\text { Encaminhava } \\
\text { educação } \\
\text { profissional e } \\
\text { literária dos filhos } \\
\text { do associado } \\
\text { necessitado }^{70}\end{array}$ & \\
\hline $\begin{array}{l}\text { 5- Centro dos } \\
\text { Operários } \\
\text { Marmoristas }\end{array}$ & & & $\begin{array}{l}\text { Ensino teórico e } \\
\text { prático em escola } \\
\text { noturna }\end{array}$ & \\
\hline $\begin{array}{l}\text { 6- Liga Federal } \\
\text { dos Empregados } \\
\text { em Padaria no Rio } \\
\text { de Janeiro }\end{array}$ & & $\begin{array}{l}\text { Intuito de manter } \\
\text { biblioteca }\end{array}$ & $\begin{array}{l}\text { Intuito de fundar } \\
\text { escolas onde os } \\
\text { sócios possam } \\
\text { aprender o } \\
\text { português e o } \\
\text { esperanto }\end{array}$ & \\
\hline $\begin{array}{l}\text { 7- Partido } \\
\text { Operário }\end{array}$ & Echo Popular & & & \\
\hline $\begin{array}{l}\text { 8- Partido } \\
\text { Operário do Brasil }\end{array}$ & $\begin{array}{l}\text { O Socialista (São } \\
\text { Paulo) }\end{array}$ & & & \\
\hline $\begin{array}{l}\text { 9- Partido } \\
\text { Socialista } \\
\text { Brasileiro }\end{array}$ & Gazeta Operária & & & \\
\hline $\begin{array}{l}\text { 10- Sociedade } \\
\text { Cosmopolita } \\
\text { Protetora dos } \\
\text { Empregados de } \\
\text { Padaria }\end{array}$ & O Panificador & & & \\
\hline $\begin{array}{l}\text { 11- Sociedade de } \\
\text { Resistência dos } \\
\text { Trabalhadores em } \\
\text { Trapiches e Café }\end{array}$ & $\begin{array}{l}\text { Intuito de jornal } \\
\text { de propaganda }\end{array}$ & $\begin{array}{l}\text { Intuito de } \\
\text { biblioteca }\end{array}$ & $\begin{array}{l}\text { Intuito de aulas de } \\
\text { instrução }\end{array}$ & $\begin{array}{l}\text { Intuito de } \\
\text { conferências e } \\
\text { publicações que } \\
\text { interessem à classe } \\
\text { e sejam fonte de } \\
\text { instrução e } \\
\text { educação cívica }\end{array}$ \\
\hline 12- Sociedade dos & Acordem! & & & \\
\hline
\end{tabular}

70 Procurava promover a admissão dos filhos dos sócios em estabelecimentos educacionais enquanto a associação não possuísse um congênere. 


\begin{tabular}{|c|c|c|c|c|}
\hline $\begin{array}{l}\text { Carpinteiros e } \\
\text { Artes Correlativas }\end{array}$ & & & & \\
\hline $\begin{array}{l}\text { 13- Sociedade } \\
\text { Operária do } \\
\text { Jardim Botânico }\end{array}$ & & & $\begin{array}{l}\text { Cursos para } \\
\text { operários }\end{array}$ & \\
\hline $\begin{array}{l}\text { 14- Sociedade } \\
\text { União dos } \\
\text { Foguistas }\end{array}$ & & $\begin{array}{l}\text { Instruir e orientar } \\
\text { por meio de } \\
\text { biblioteca }\end{array}$ & & $\begin{array}{l}\text { Instruir e orientar } \\
\text { por meio de } \\
\text { conferências }\end{array}$ \\
\hline $\begin{array}{l}\text { 15- União dos } \\
\text { Operários das } \\
\text { Pedreiras }\end{array}$ & $\begin{array}{l}\text { O Congresso } \\
(1905-1906)\end{array}$ & & & \\
\hline $\begin{array}{l}\text { 16- União dos } \\
\text { Operários } \\
\text { Estivadores }\end{array}$ & $\begin{array}{l}\text { Intuito de jornal } \\
\text { de propaganda }\end{array}$ & $\begin{array}{l}\text { Intuito de criação } \\
\text { de biblioteca }\end{array}$ & $\begin{array}{l}\text { Intuito de aulas de } \\
\text { instrução primária }\end{array}$ & $\begin{array}{l}\text { Intuito de } \\
\text { realização de } \\
\text { conferências }\end{array}$ \\
\hline $\begin{array}{l}\text { 17- União } \\
\text { Operária do } \\
\text { Engenho de } \\
\text { Dentro }\end{array}$ & & & $\begin{array}{l}\text { Escola primária } \\
\text { para crianças dos } \\
\text { dois sexos }\end{array}$ & \\
\hline $\begin{array}{l}\text { 18- União } \\
\text { Protetora do } \\
\text { Comércio Volante }\end{array}$ & & $\begin{array}{l}\text { Intuito de criar } \\
\text { biblioteca }\end{array}$ & $\begin{array}{l}\text { Intuito de criar } \\
\text { escolas de } \\
\text { instrução }\end{array}$ & \\
\hline
\end{tabular}

As informações que figuram na tabela a cima foram organizados de acordo com as atividades educacionais mais comuns nos períodos estabelecidos para análise da formação da classe trabalhadora no Rio de Janeiro (manutenção de aulas, de bibliotecas, promoção de conferências e edição de jornais). O recorte, como já foi salientado, abarca a passagem do caráter beneficente/mutualista e estratificado para um mais classista e reivindicativo. Nem todas as associações tabuladas foram analisadas profundamente no corpo do texto, pois o que presidiu a composição da tabela foi o dado (mesmo que pontual) do desenvolvimento daquelas atividades educativas percebidas nas variadas fontes já citadas na abertura deste capítulo.

A sistematização desses dados mostra, mais uma vez, a importância atribuída à cultura letrada e à instrução tanto pelas associações atuantes entre 1870 e 1890, como naquelas fundadas entre 1890 e 1917. O desenvolvimento, ou o intuito de desenvolver aulas sob o formato escolar é uma constante desde a segunda metade do século XIX até os primeiros anos do século XX e ocorrem na maioria das organizações tabuladas: $90 \%$ no primeiro período e $61 \%$ no segundo período. A manutenção de bibliotecas e promoção de conferências são mais raras em ambos os períodos: $45 \%$ e $38 \%$ respectivamente para bibliotecas e $36 \%$ e $16 \%$ respectivamente para conferências. Podemos imaginar que o menor número de iniciativas de bibliotecas em relação às aulas seja condicionado pelo próprio custo de sua montagem e manutenção. Já o menor número de conferências talvez possa ser atribuído à preferência pelo investimento em um formato escolar de 
ensino representado pelas aulas. Enquanto as conferências se caracterizariam mais por uma expressão de cultura oral, as aulas introduziriam a escrita como forma de saber que vinha se tornando hegemônica.

Por fim, encontramos uma disjunção entre o primeiro e segundo período no que tange aos periódicos. Dezoito por cento das associações atuantes entre 1870 e 1890 editavam periódicos, enquanto cinquenta e seis por cento das fundadas a partir de 1890 até 1917 possuíam ou tinham intenção de possuir um órgão de propaganda. Esse dado expressa claramente a citada mudança no caráter das organizações de trabalhadores, mas além disso nos sugere que, avançando em seu processo de educação, as classes trabalhadoras passaram a sentir necessidade de educar também o restante da sociedade.

Estas são, porém, dimensões da existência das classes populares geralmente subestimadas, especialmente ao se tratar da educação voltada para elas no século XIX, situação bastante contingenciada pelo acesso às fontes, mas também pelos caminhos interpretativos. $\mathrm{O}$ cotidiano e a experiência são deslegitimados como forma de saber, nada óbvios, e ainda fugidios. Costuma-se repetir que existem, mas, ao menos em história da educação, ainda carecemos de pesquisas que os tragam à vida. Muitas vezes, o pesquisador imerso no universo acadêmico, naturaliza sua condição escolarizada, deixando de ver os "saberes dos outros", ou vendo-os sob o signo da falta: aqueles a quem falta/faltou escola. $\mathrm{O}$ aspecto cotidiano da educação do povo não tem muita expressão na história, carecendo do mesmo apelo de episódios das lutas econômicas ou políticas que emergem para cena pública. Quando aparece sob a forma de reformas e políticas promovidas pelo Estado, a educação ganha maior visibilidade, mas este é apenas um de seus sentidos, o que parte das elites governantes para as classes populares.

O contato sistemático com a bibliografia tem mostrado não o alijamento da questão educacional popular, mas uma dispersão de dados. A discussão dos saberes de experiência e mesmo das diferentes formas de escolarização das classes populares pode ser encontrada de forma difusa, ainda que mais ou menos abundante na historiografia que aborda temas como escravidão e classes trabalhadoras na segunda metade do século XIX. Seu processo educacional e o exercício de seus saberes emerge na fala dos historiadores ainda que não seja destacado. Nesse sentido, o caso dos estudos sobre os tipógrafos é bastante exemplar. Primeiro pela própria natureza do "objeto", além do fato da categoria ${ }^{71}$ possuir uma sólida associação portadora do título de "imperial", de terem realizado a primeira greve da história da nação e de terem lançado, nesse contexto, um jornal para expor seus motivos e demandas, sabemos que eram uma das parcelas mais letradas no universo das classes trabalhadoras. Essa característica fez com que legassem mais ampla documentação escrita,

71 Usamos hoje o termo categoria para referirmo-nos a um determinado segmento profissional. No século XIX, era mais comum o uso do termo "classe" para tal finalidade. 
não só para nós historiadores, mas, na própria época, para trabalhadores de outros ofícios. Os tipógrafos foram difusores de ideias e importantes no processo de educar-se das classes trabalhadoras na segunda metade do século XIX.

No estudo feito por Artur Vitorino sobre a greve dos compositores tipógrafos em 1858, a dimensão educativa da associação e da própria greve aparecem como importantes, embora não destacadas. Segundo ele,

...a Associação Tipográfica Fluminense foi utilizada pelos compositores tipográficos e favoreceu: suas lutas reivindicatórias; a incrementação cultural (conferências, instalação de biblioteca, que teve seu início em 1854); a intervenção nos problemas técnicos e econômicos do setor gráfico (a questão das tarifas alfandegárias do papel impresso, das tintas das máquinas, a defesa da reorganização da Tipografia Nacional, incentivos à estética tipográfica, promoção para o melhoramento da instrução artística, etc.) (VITORINO, 1999, p. 72).

Alguns termos que no texto de Vitorino compõe o quadro mais amplo da exposição sobre os tipógrafos e a greve, seu objeto de estudo, podem nos remeter às formas de construção intelectual prontas a serem compartilhadas: "O jornal dos tipógrafos assim funciona como um intérprete da greve iniciada pelos compositores, pois nele se avalia, se julga, interpreta, em suma, dá-se um sentido às causas e às consequências da greve dos compositores junto à opinião pública" (VITORINO, 1999, p. 86). Avaliar, interpretar, julgar, dar sentido, não se fala aqui de bacharéis formados em Coimbra, ou literatos formados em faculdades de direito, mas sim de tipógrafos. Mais do que imprimir, eles também formulavam ideias.

Outros trabalhadores por toda corte e província associavam-se procurando resolver seus problemas imediatos, esforço que era extrapolado à medida que os levava a articularem visões sobre a sociedade em que vivam e aspirações para a coletividade em que se inseriam. A maioria desses trabalhadores não formulou projetos universais e expansionistas para a sociedade nacional e sua educação. O que pode parecer "alienação", talvez, simplesmente, não fosse seu interesse. A final, a que custos, projetos de poder centralizadores e expansionistas, cujos representantes máximos nas sociedades modernas são os Estados nacionais, conseguem governar desejos tão diversos e até divergentes.

Era outra política, que sem se isolar do plano macro dos Estados, encontrava seus contornos no cotidiano, onde esta mesma era aprendida, porque vivenciada. Vivência como a dos caixeiros na busca pela redução de sua jornada de trabalho durante o movimento pelo fechamento das portas de estabelecimentos comerciais estudado por Popinigis (1999). Em seu texto podemos observar na organização e luta desses trabalhadores uma experiência formativa que faz uso da palavra escrita como ferramenta. Segundo a autora, "Nas cartas enviadas aos membros do conselho municipal e à 
imprensa, os caixeiros assumiam um discurso que construía sua imagem de trabalhadores honestos. Assim habilitavam-se para exigir a recíproca relação. Ou seja, utilizavam-se do direito de pedir, para, de fato, exigir providências contra patrões que insistiam em manter suas portas abertas em domingos e feriados" (POPINIGIS, 1999, p. 113). Os caixeiros sabiam interpretar a realidade social e as relações de poder nas quais estavam imersos. Em sua escrita "pediam",72, quando de fato estavam a "exigir". Mas, talvez, em dado momento, ao reavaliarem suas forças, o perfil do movimento observasse uma mudança. “... de lutas para dentro das portas das lojas passa-se a um cunho reivindicativo e coletivo: abaixo assinados, comícios. Conseguiram que aos poucos os patrões negociassem e fechassem as portas às 8 da noite e aos domingos, seguiram reivindicando garantia legal para essa conquista" (POPINIGIS, 1999, p. 114).

Varela e Uria (1992) ao tratarem do desenvolvimento da escola moderna consolidada e difundida desde a Europa entre fins do século XIX e início do XX identificam a "escola pública e obrigatória" como uma das principais formas de socialização então adotadas pelas sociedades modernas. Os autores explicam que tal modelo constituiu-se numa "maquinaria de governo da infância" destinada, principalmente, a civilizar a massa da população, as classes trabalhadoras. Este modelo educacional teria começado a se formar desde o século XVI e teria como condições de aparecimento seis aspectos principais: a definição de um estatuto de infância; a delimitação de um espaço específico; o aparecimento de especialistas da infância; a destruição de outros modelos de educação; e a obrigatoriedade escolar. Estas condições de existência também são usadas por Vincent, Lahire e Thin (2001) em seu trabalho de referência em que defendem a emergência de uma "forma escolar" por volta do mesmo período ${ }^{73}$.

Interessa ressaltar aqui o quarto aspecto delimitado por Varela e Uria, "a destruição de outras formas de socialização", pois nos leva a pensar de que maneira a escolarização dos saberes sociais contribuiu na deslegitimação de formas educacionais próprias das classes populares como as que procuro identificar no interior das associações.

A partir de agora a memória dos povos, os saberes adquiridos no trabalho, suas produções culturais, sua lutas, ficarão marcadas com o estigma do erro e desterradas do campo da cultura, a única legítima porque está legitimada pelo mito da "neutralidade" e da "objetividade" da ciência. (...)

Obviamente as formas de saber e de socialização do campesinato, e em geral das classes populares, serão qualificadas sem piedade pelos novos propagandistas da verdade legítima de "néscios princípios", "vulgares opiniões" e "mentecaptas superstições".

72 O que pode parecer sinal de submissão, mas que era a forma possível de interlocução numa sociedade monárquica de antigo regime em que vigoravam as relações paternalistas e a restrição de direitos de cidadania para as classes subalternizadas.

73 Para o caso específico do desenvolvimento da forma escolar no Brasil/São Paulo ver Hilsdorf (2006). 
Os artesãos socializavam-se na mesma comunidade de pertencimento, formavam grêmios, irmandades ou corporações dotadas de determinados privilégios e usavam seus direitos para intervir na coisa pública do mesmo modo que as universidades medievais. A aprendizagem implicava neste caso num sistema de transmissão de saber que se fazia de forma hierarquizada na oficina, aquela, além de ser lugar de trabalho, era lugar de educação, instrução e habitat; nela coexistiam transmissão de saberes e trabalho produtivo. (...) A imposição da escola obrigatória romperá de forma definitiva esses laços (VARELA \& URIA, 1992, p. 86).

Falta a Varela e Uria abordar o sentido inverso da relação, o da ressignificação dos saberes escolarizados pelas classes populares e das formas de resistência dos saberes de experiência. A historiografia e a historiografia da educação em particular, ao repensar o estigma de obscurantismo educacional imposto à sociedade brasileira do século XIX têm buscado ressaltar uma racionalidade/consciência das ações de diferentes sujeitos da sociedade civil, bem como suas práticas de leitura e escrita e as formas de obtenção de instrução seja no circuito das instituições públicas ou de iniciativas particulares.

Para Faria Filho (2003), discutir outras instituições e outros locus do educativo nos ajuda a compreender a própria escola, o que remete a necessidade de pesquisarmos "de forma mais decidida os processos socializadores que ocorreram na família, na igreja e no trabalho, para que possamos compreender as apropriações realizadas pela escola em relação a essas 'outras culturas' e formas de socialização quanto dimensionar as transformações nelas efetuadas a partir do advento da escola" (FARIA FILHO, 2003, p. 95). Avançando na reflexão, Vidal e Biccas (2008) tematizam uma escolarização que vai além da educação formal obtida por meio da escola estatal ao entenderem a escolarização como estratégia instaurada pelo Estado, mas não apenas. "Para nós, evidencia-se como importante atentar para os vários projetos educativos colocados em jogo por movimentos e grupos sociais (movimento negro, igreja católica, lojas maçônicas, imigrantes, dentre outros) na criação de escolas, na definição de modelos educacionais e no funcionamento de iniciativas em permanente diálogo e negociação com os investimentos oficiais” (VIDAL \& BICCAS, 2008, p. 28, 29). Visões que ajudam a relativizar o senso comum do povo adverso à educação e mesmo à escola, do que decorreria sua "ignorância".

Maciel (2006) parte da compreensão que a afirmação do povo como analfabeto, portanto ignorante, reforçada por estatísticas e indicadores educacionais (níveis de alfabetização, etc.) acaba por justificar o domínio e condução desse mesmo "povo" pelas "elites governantes". A partir daí seu trabalho busca outras possibilidades de reflexão sobre o processo de difusão da cultura letrada em nossa sociedade. Em um texto sugestivamente intitulado como Do "o povo não sabe ler" para uma história dos trabalhadores da palavra a autora identifica na passagem do século XIX para o XX, uma ampliação da comunicação social com novos grupos produtores, difusores e leitores, pondo em 
cena muitos dos sujeitos referidos no presente tese.

Outra constatação é a participação de indivíduos, grupos e organizações populares em congressos, campanhas e movimentos para expansão do ensino e formulação de projetos educacionais populares. (...) A frequência com que flagramos referências a trabalhadores como carteiros, telegrafistas, funcionários de estradas de ferro, do corpo de bombeiros ou compositores e músicos populares atuando em distintos espaços e iniciativas letradas ou defendendo com insistência a expansão do ensino, tanto primário quanto técnico, nas páginas de seus periódicos, são também indicações da crescente alfabetização da população, por meio da expansão da instrução pública e particular sem esquecer das escolas mantidas por associações de classe. Indicam, também, a intensificação do movimento que permitiu que "a escrita descesse do pedestal" e invadisse a vida cotidiana ampliando a rede potencial de leitores não só de jornais e revistas, mas também de livros. Se considerarmos que inúmeras outras profissões - trabalhadores gráficos, professores, empregados do comércio, caixeiros, funcionários públicos, guarda-livros - exigiam, em maior ou menor grau, o domínio da leitura e da escrita, podemos supor que o crescimento e a maior complexidade das atividades econômicas nos grandes centros urbanos foram acompanhados por maiores demandas de trabalhadores aptos para registrar suas experiências e ações, merecendo pesquisas mais amplas além dos trabalhos já existentes sobre algumas categorias. (MACIEL, 2006, p. 212)

De acordo com as pesquisas de Maciel a representação dos sujeitos trabalhadores anônimos como analfabetos, avessos à leitura, incapazes de compreender o mundo ao redor, corrente ainda hoje e mais exacerbada se nos referimos à épocas anteriores à segunda metade do século XX é contradita pela análise de fontes literárias como a crônica de João do Rio sobre operários leitores apresentada por ela. O que nos leva a crer que tais estigmas não sobrevivem quando perscrutada a experiência daquela sociedade.

O trabalho da autora, bastante inspirador para o desenvolvimento desta tese, coloca a questão educacional no centro de sua construção histórica. Ela pesquisa a luta dos trabalhadores pela expansão do ensino, seja por reivindicação, seja por criação de suas próprias alternativas. E questiona: o quanto projetos dissidentes foram incorporados à políticas públicas de educação popular? Era a instrução um meio de fazer-se presente no cenário político? Estratégia de luta dos trabalhadores? Em busca de repostas para as questões ela procura:

(...) definir e trilhar caminhos de pesquisa que revelem iniciativas de grupos e associações de trabalhadores na cidade do Rio de Janeiro com a luta pela expansão do ensino, seja por meio de pressões pela ampliação do número de escolas e cursos por parte do Estado ou mapeando experiências em que trabalhadores assumiram eles mesmos essa tarefa criando escolas, bibliotecas, aulas noturnas, centros de cultura etc. Ao mesmo tempo em que registro, busco indagar sobre o que essas experiências indicam: o que 
propunham, desejavam, reivindicavam esses trabalhadores? Em que medida recuperar esses projetos nos ajuda a repensar possibilidades alternativas, diferentes projetos de presente naquele passado e, inclusive, avaliar se projetos dissidentes foram incorporados em políticas públicas para a educação popular? Será que por meio dessas reivindicações por educação e alfabetização podemos recuperar significados políticos da leitura/escola/educação como condição para presença pública desses trabalhadores na cidade e de sua participação em embates políticos? Em que medida reivindicar o direito à educação e empenhar-se na criação de escolas e bibliotecas, periódicos e outras publicações, constitui estratégias de luta contra a exclusão política desses trabalhadores"? (MACIEL, p. 216 e 217).

Seguindo essa trilha na busca do papel educacional ativo das classes populares na sociedade oitocentista, não pretendo, entretanto, negar a dominação cultural existente, as restrições de acesso à escola e demais bens do conhecimento humano sofridas por estes sujeitos, nem negar as altas taxas de analfabetismo do período, quanto menos esvaziar a importância dos saberes escolarizados. Existia, na segunda metade do século XIX, bem como existe hoje, uma ordem instituída a favor de elites proprietárias e governantes que dificultava ao povo trabalhador e pobre o desenvolvimento da instrução, principalmente uma trajetória escolar além do nível primário. Essa ordem condicionava, porém não determinava completamente as ações dos sujeitos. O raciocínio, desenvolvido por E. P. Thompson (1981) em sua crítica ao estruturalismo de Althusser é profícuo no que nos ajuda a refletir sobre as intervenções intelectuais e políticas das classes populares como produtoras de conhecimento e propostas políticas. Isto porque restitui aos "seres sociais", principalmente os trabalhadores, a capacidade de pensar, de dar "respostas mentais e emocionais" a "muitos acontecimentos inter-relacionados ou a muitas repetições do mesmo acontecimento". (THOMPSON, 1981, p. 15)

Valorizando a experiência menosprezada muitas vezes como pura ação sem reflexão ele mostra que

A experiência surge espontaneamente no ser social, mas não surge sem pensamento. Surge porque homens e mulheres (e não apenas filósofos) são racionais, e refletem sobre o que acontece a eles e ao seu mundo. Se tivermos que empregar a (difícil) noção, de que o ser social determina a consciência social, como iremos supor que isso se dá? Certamente não iremos supor que o "ser" está aqui, com uma materialidade grosseira da qual toda idealidade foi abstraída, e que a "consciência", (como idealidade abstrata) está ali. Pois não podemos conceber nenhuma forma de ser social independentemente de seus conceitos e expectativas organizadores, nem poderia o ser social reproduzir-se um único dia sem o pensamento. $\mathrm{O}$ que queremos dizer é que ocorrem mudanças no ser social que dão origem à experiência modificada, e essa experiência é determinante. Talvez pudesse argumentar que a experiência é realmente um nível muito inferior de mentação; que ela só pode produzir o mais grosseiro "senso comum", "matéria-prima" ideologicamente contaminada, que dificilmente se 
qualificaria para ingresso no laboratório de Generalidades I. Não creio que seja assim - pelo contrário, considero tal suposição como uma ilusão muito característica dos intelectuais, que supõe que os comuns mortais são estúpidos. Em minha opinião a verdade é mais nuançada: a experiência é válida e efetiva, mas dentro de determinados limites: o agricultor conhece suas estações, o marinheiro conhece seus mares, mas ambos permanecem mistificados em relação à monarquia e à cosmologia. (THOMPSON, 1981, p. 16 e 17)

O termo seria, então, não uma concessão de um intelectual condescendente com os seres sociais, especialmente as "pessoas comuns", mas uma forma de imprimir dinâmica ao olhar histórico. Ela nos permitiria ver como as mudanças ocorrem quando os seres refletem e agem sobre sua própria vida e o mundo à volta, pois que se não, seriam autômatos. Ela nos permite ver como as classes populares na Corte e Província do Rio de Janeiro participaram da instauração de determinados projetos educacionais, fossem eles projetos vencedores ou vencidos, em todo caso fruto de lutas. 


\section{Capítulo 3- A educação das classes trabalhadoras na imprensa e pela imprensa}

E todos os que me ouviam ler o jornal, estavam como que perplexos diante da grave descoberta que lhes ia ser anunciada; eu mesmo suspendi a leitura um instante a fim de prepara-me para a surpresa. Pois ao fim daquele exordio todo, diz ele, semelhante à montanha que pariu um rato, que a culpa é dos donos de padarias que não controlam seu pessoal.

Toda a indignação acumulada nos meus ouvintes pronta a explodir contra o mau que ia ser apontado a seu conhecimento, desfez-se numa sonora gargalhada, que me fez compreender o meu engano em tomar a sério uma coisa que só deveria ser encarada pelo lado pitoresco. (A Mercúrio.

In: O Panificador. Órgão dedicado aos interesses da classe dos empregados em padaria)

\section{1- Caracterização da imprensa dos trabalhadores}

Desde o movimento de ampliação do conceito de fonte histórica impulsionado pela École dos Annales, a imprensa vem se apresentando como meio privilegiado de acessar o universo de experiências humanas. As últimas décadas do XIX e início do XX no Rio de Janeiro são marcadas por extraordinária ampliação do número de periódicos. Segundo Barbosa (2010) no ano de 1881, no Rio de Janeiro, apareceram 95 novos periódicos e no ano seguinte mais 64. Em 1900, o Rio possuía pouco mais de 500 mil habitantes e os 5 principais jornais faziam circular cerca de 150.000 exemplares. Todo esse material traz indubitáveis contribuições às nossas buscas pelos saberes populares no período. Uma mostra desse vasto universo é apresenta na tabela de jornais que se segue. Ela contém títulos operários catalogados na década de 1970, por Maria de Nazareth Ferreira (1978) que trabalhou com o Arquivo Edgar Leuenroth, do Departamento de Ciências Sociais da Universidade Estadual de Campinas.

Tabela 4: Jornais operários editados em português entre a segunda metade do século XIX e início do século XX no Rio de Janeiro

\begin{tabular}{|l|l|l|l|}
\hline Ano & Título & Editores & Local \\
\hline 1858 & Jornal dos Tipógrafos & $\begin{array}{l}\text { Associação dos } \\
\text { Tipógrafos }\end{array}$ & RJ, capital \\
\hline 1868 & O Tipógrafo & & \\
\hline 1875 & A Gazeta Operária & Arsenal da Marinha & RJ, capital \\
\hline 1876 & A Revolução Social & - & RJ, capital \\
\hline 1878 & O Socialista & - & RJ, capital \\
\hline 1879 & O Trabalho & - & RJ, capital \\
\hline 1880 & A Revolução & - & RJ, capital \\
\hline 1881 & O Carbonário & - & RJ, capital \\
\hline 1881 & Gutemberg & - & RJ, capital \\
\hline
\end{tabular}




\begin{tabular}{|c|c|c|c|}
\hline 1883 & O Niilista & $\begin{array}{l}\text { Operários do Exército e } \\
\text { Armada }\end{array}$ & RJ, capital \\
\hline 1885 & Jornal dos Alfaiates & Liga dos Alfaiates & RJ, capital \\
\hline 1888 & Revista Tipográfica & Luis de França & RJ, capital \\
\hline 1890 & A Voz do Povo & - & RJ, capial \\
\hline 1893 & O Despertar & $\begin{array}{l}\text { Grupo Anarquista } \\
\text { Angiolillo }\end{array}$ & RJ, capital \\
\hline 1894 & O Operário Italiano & - & RJ, capital \\
\hline 1895 & O Operário & - & RJ, Campos \\
\hline 1896 & A Nova Revista & - & RJ, capital \\
\hline 1899 & O Liberalista & - & RJ, capital \\
\hline 1899 & O Protetsto & J. Motta Assumpção & RJ, capital \\
\hline 1899 & O Mensageiro & - & RJ, capital \\
\hline 1900 & O Golpe & - & RJ, capital \\
\hline 1900 & Tribuna Operária & - & RJ, capital \\
\hline 1902 & Asgarda & - & RJ, capital \\
\hline 1902 & Emancipação & Liga das Artes Gráficas & RJ, capital \\
\hline 1903 & A Greve & $\begin{array}{l}\text { Sindicato dos } \\
\text { Estivadores }\end{array}$ & RJ, capital \\
\hline 1903 & Gazeta Operária & - & RJ, capital \\
\hline 1903 & A Federação & $\begin{array}{l}\text { Federação das } \\
\text { Associações de Classe } \\
\text { do Rio de Janeiro }\end{array}$ & RJ, capital \\
\hline 1903 & O Gráfico & Associação Gráfica & RJ, capital \\
\hline 1903 & A Voz do Marmorista & União dos Marmoristas & RJ, capital \\
\hline 1903 & O Trabalhador & - & RJ, capital \\
\hline 1903 & O Alfaiate & Alfredo Vasquez & RJ, capital \\
\hline 1904 & Kultur & - & RJ, capital \\
\hline 1904 & União Operária & - & RJ, capital \\
\hline 1904 & O Marmorista & - & RJ, capital \\
\hline 1904 & O Libertário & $\begin{array}{l}\text { Manuel Moscoso, } \\
\text { Neno Vasco e E. Dias }\end{array}$ & RJ, capital \\
\hline 1905 & Acordem! & $\begin{array}{l}\text { Associação dos } \\
\text { Carpinteiros }\end{array}$ & RJ, capital \\
\hline 1905 & A Luz Marítima & $\begin{array}{l}\text { Associação de } \\
\text { Resistência dos } \\
\text { Marinheiros e } \\
\text { Remadores }\end{array}$ & RJ, capital \\
\hline 1905 & O Congresso & $\begin{array}{l}\text { Liga de Resistência dos } \\
\text { Operários em Pedreiras }\end{array}$ & RJ, capital \\
\hline
\end{tabular}




\begin{tabular}{|c|c|c|c|}
\hline 1905 & Novo Rumo & $\begin{array}{l}\text { Joel de Oliveira, Luiz } \\
\text { Magrassie M. } \\
\text { Assunção }\end{array}$ & RJ, capital \\
\hline 1906 & O Veículo & $\begin{array}{l}\text { Associação dos } \\
\text { Empregados em } \\
\text { Ferrovias }\end{array}$ & RJ, capital \\
\hline 1906 & Gazeta Operária & Mariano Garcia & RJ, capital \\
\hline 1907 & O Sindicalista & União dos Barbeiros & RJ, capital \\
\hline 1907 & Gazeta de Notícias & - & RJ, capital \\
\hline 1907 & Floreal & Lima Barreto & RJ, capital \\
\hline 1907 & O Baluarte & $\begin{array}{l}\text { Liga de Resistência dos } \\
\text { Chapeleiros }\end{array}$ & RJ, capital \\
\hline 1907 & Semana Operária & - & RJ, capital \\
\hline 1907 & O Trabalho & - & RJ, Campos \\
\hline 1908 & Não Matarás & $\begin{array}{l}\text { Liga Antimilitarista } \\
\text { Brasileira }\end{array}$ & RJ, capital \\
\hline 1908 & Ecos de Caserna & - & RJ, capital \\
\hline 1908 & A Voz do Trabalhador & $\begin{array}{l}\text { Confederação Operária } \\
\text { Brasileira }\end{array}$ & RJ, capital \\
\hline 1908 & A Voz do Povo & - & RJ, capital \\
\hline 1908 & A Liberdade & Manuel Moscoso & RJ, capital \\
\hline 1908 & O Lutador & - & RJ, capital \\
\hline 1909 & Liberdade & Paul Berthelot & RJ, capital \\
\hline 1909 & O Independente & - & RJ, capital \\
\hline 1911 & A Vanguarda & J. Motta Assunção & RJ, capital \\
\hline 1911 & A Guerra Social & $\begin{array}{l}\text { João Arzua, Gigi } \\
\text { Damiani e Everardo } \\
\text { Dias }\end{array}$ & RJ, capital \\
\hline 1912 & O Progresso & $\begin{array}{l}\text { União da Central do } \\
\text { Brasil }\end{array}$ & RJ, capital \\
\hline 1913 & A Voz do Padeiro & União dos Padeiros & RJ, capital \\
\hline 1913 & A Liberdade & - & RJ, capital \\
\hline 1913 & A Época & - & RJ, capital \\
\hline 1913 & Coluna Operária & - & RJ, capiatl \\
\hline 1914 & A Vida & $\begin{array}{l}\text { José Oiticica e } \\
\text { Francisco Viotti }\end{array}$ & RJ, capital \\
\hline 1914 & A Rebelião & Florentino de Carvalho & RJ, capital \\
\hline 1914 & A Careta & $\begin{array}{l}\text { Domingos Ribeiro } \\
\text { Filho }\end{array}$ & RJ, capital \\
\hline 1914 & O Cosmopolita & - & RJ, capital \\
\hline
\end{tabular}




\begin{tabular}{|c|c|c|c|}
\hline 1915 & A Voz do Padeiro & - & RJ, capital \\
\hline 1915 & Na Barricada & Orlando Correa Lopez & RJ, capital \\
\hline 1916 & O Gráfico & $\begin{array}{l}\text { Associação das Artes } \\
\text { Gráficas do Rio de } \\
\text { Janeiro }\end{array}$ & RJ, capital \\
\hline 1917 & Liberdade & Pedro Matera & RJ, capital \\
\hline 1918 & Crônica Subversiva & Astrogildo Pereira & RJ, capital \\
\hline 1918 & Clarté & Grupo Clarté & RJ, capital \\
\hline 1918 & $\begin{array}{l}\text { Boletim da Aliança } \\
\text { Anarquista }\end{array}$ & $\begin{array}{l}\text { Aliança Anarquista do } \\
\text { Rio de Janeiro }\end{array}$ & RJ, capital \\
\hline 1919 & Voz Operária & - & RJ, Campos \\
\hline 1919 & Spartacus & $\begin{array}{l}\text { Salvador Alcid, José } \\
\text { Oiticica, e A. Pereira }\end{array}$ & RJ, capital \\
\hline 1919 & A Seara & - & RJ, capital \\
\hline 1919 & O Germinal & $\begin{array}{l}\text { José Oiticica e } \\
\text { Astrogildo Pereira }\end{array}$ & RJ, capital \\
\hline 1919 & Folha Nova & Nestor de Oliveira & RJ, capital \\
\hline 1919 & A Aurora & Santos Jr. & RJ, capital \\
\hline 1920 & A Voz do Povo & $\begin{array}{l}\text { Federação dos } \\
\text { Trabalhadores do Rio } \\
\text { de Janeiro }\end{array}$ & RJ, Petrópolis \\
\hline 1920 & Nova Sociedade & José Nascimento & RJ, capital \\
\hline 1920 & Evolução & - & RJ, capital \\
\hline 1920 & Diário & - & RJ, capital \\
\hline 1921 & A Renovação & Mancio Teixeira & RJ, capital \\
\hline 1921 & O Trabalho & Marques da Costa & RJ, capital \\
\hline 1921 & O Tecelão & - & RJ, Petrópolis \\
\hline 1921 & O Metalúrgico & $\begin{array}{l}\text { União dos } \\
\text { Metalúrgicos }\end{array}$ & RJ, capital \\
\hline 1921 & O Intransigente & Arbaldo Benjamin & RJ, capital \\
\hline 1921 & $\begin{array}{l}\text { Boletim da Liga } \\
\text { Operária da Construção } \\
\text { Civil }\end{array}$ & $\begin{array}{l}\text { Liga Operária da } \\
\text { Construção Civil }\end{array}$ & RJ, Niterói \\
\hline 1921 & Alvorada & - & RJ, Petrópolis \\
\hline 1921 & Solidariedade & $\begin{array}{l}\text { Comitê de Socorro aos } \\
\text { Flagelados Russos }\end{array}$ & RJ, capital \\
\hline 1922 & Movimento Comunista & Astrogildo Pereira & RJ, capital \\
\hline 1922 & Voz Cosmopolita & $\begin{array}{l}\text { Sindicato dos } \\
\text { Empregados em Hotéis } \\
\text { e Similares }\end{array}$ & RJ, capital \\
\hline
\end{tabular}




\begin{tabular}{|l|l|l|l|}
1922 & Luta Social & $\begin{array}{l}\text { Grupo de Propaganda } \\
\text { Social }\end{array}$ & RJ, capital \\
\hline 1922 & O Panificador & $\begin{array}{l}\text { Sindicato do Ramo } \\
\text { Alimentício em Geral }\end{array}$ & RJ, capital \\
\hline 1923 & O Nosso Jornal & $\begin{array}{l}\text { Grupo Emancipação } \\
\text { Feminina }\end{array}$ & RJ, capital \\
\hline
\end{tabular}

Fonte: Tabela de jornais operários editados no Rio de Janeiro, transcrita da obra de Maria de Nazareth Ferreira. A Imprensa Operária no Brasil, 1880 - 1920.

A tabela 4 nos dá a dimensão do grande volume de títulos editados por indivíduos ou associações operárias nas últimas décadas do século XIX e primeiras décadas do XX, período que, como já chamamos a atenção, foi delimitado pela historiografia relacionada ao "mundo do trabalho" como da formação da classe trabalhadora no Rio de Janeiro. Estes e outros periódicos foram testemunhos e atores nesta formação. É interessante lembrar que, de acordo com Ferreira (1978), os títulos aqui expostos eram os editados em português. A autora apresenta, ainda, uma tabela que optamos por não reproduzir, como o quadro dos jornais editados, no Rio de Janeiro, em língua estrangeira.

A imprensa é encarada, nesta tese, em continuidade com a abordagem das associações empreendida no capítulo 2, como fonte privilegiada para acessar a experiência das classes populares, também por ser uma forma de relação com o mundo da leitura e escrita que não estava necessariamente na escola. Meio de comunicação, circulação de ideias, ela não está restrita à população alfabetizada. Informa-nos sobre acontecimentos de um determinado tempo, sobre quem os publiciza e especulativamente sobre o público que os recebe e sobre os efeitos daquilo que foi veiculado em determinada formação social.

Tomo de empréstimo a concepção de Marialva Barbosa (2010) para quem a imprensa seria "testemunho e protagonista, peculiar agente histórico", da qual deriva a questão de "como os impressos periódicos interagem na complexidade do contexto"? Questão representativa do que Marco Morel classificou, no prefácio da mesma obra, como "história social e cultural da comunicação impressa”. Pontos chave desenvolvidos ao longo da obra de Barbosa como a ruptura da barreira entre oralidade e escrita; o foco no público; a auto referência da própria imprensa; além da escolha dos protagonistas de sua história: "não apenas os membros da elite letrada de escribas, mas a ampla gama da desigual hierarquia da sociedade, inclusive os escravos que merecem um capítulo especial" (BARBOSA, 2010, p. 10) dão a medida das possibilidades de interlocução com o presente texto.

Ao debruçar-se sobre a imprensa oitocentista, Barbosa (2010) questiona: como a informação era transformada em notícia? Quem era o público leitor? Para quem as letras impressas passam a ter 
significado? Os jornais eram uma arena pública para as polêmicas da Corte: falavam uns com os outros, uns contra os outros, teatralizavam a política. Um dos públicos para quem esses jornais assumiram um significado particular foi os trabalhadores, tanto escravos como livres. Atenta a relação entre imprensa e escravos a autora defende o papel ativo dos cativos naquele terreno.

Imersos num mundo da oralidade, os escravos participavam do mundo do letramento e da leitura. Eram leitores de primeira, segunda e terceira naturezas. Eram leitores por ouvir dizer, porque escutavam as notícias e, também, de fato porque muitos sabiam ler e escrever. (...) Escravos leitores, escravos letrados, escravos mergulhados em um cotidiano em que as letras impressas passavam aos borbotões a fazer parte da vida" (BARBOSA, 2010, p. 13).

A preocupação com o papel ativo do público leitor, bem como a concepção de que também sujeitos analfabetos poderiam ter acesso e fazer uso das notícias e ideias veiculadas pelos jornais e revistas, nem sempre esteve presente na historiografia da imprensa. A obra de Maria de Nazareth Ferreira, publicada no ano de 1978, sobre a imprensa operária no Brasil entre 1880 e 1920, adotada aqui como rica fonte de informações sobre o tema, é um exemplo da ausência de tal perspectiva. Sua abordagem faz com que a figura das lideranças operárias, os redatores dos jornais, segundo a autora, imigrantes europeus, em geral, obscureçam a importância do restante da classe naquele contexto.

A obra em questão é o livro que derivou de dissertação de mestrado apresentada à Escola de Comunicação e Artes da Universidade de São Paulo e é uma representante dos primeiros esforços dos trabalhos que seguiam o rumo da história social. Na introdução afirma que seu ponto de partida é "uma História que privilegia o homem". Maria Nazareth Ferreira trabalhou com o Arquivo Edgar Leuenroth do Departamento de Ciências Sociais da Universidade Estadual de Campinas, desenvolvendo além da dissertação, onde analisou "o operário gráfico como agente comunicador dentro da formação da classe operária brasileira” (FERREIRA, 1978, p. 14) a organização e indexação de seus periódicos.

Num momento em que ainda não havia se consolidado o campo de conhecimento da história da educação, a autora adota a concepção da ausência de iniciativas institucionais de educação para trabalhadores. Ela afirma que "Durante todo o século XIX, se formaram gerações operárias, graças à atividade individual de seus líderes, de instruir-se, sem que as instituições nada fizessem a seu favor." (FERREIRA, 1978, p. 14). O estado das pesquisas em história do mundo do trabalho também não havia avançado a ponto de destacar a importância do trabalhador nacional, livre, liberto ou cativo nos processos organizativos da classe, do que resulta outra ideia de fundo adotada por Ferreira, de que "todos os elementos pioneiros na organização dos trabalhadores brasileiros eram imigrantes". Uma vez que estes seriam a parcela politizada, imbuída das ideias socialistas e 
anarquistas trazidas da Europa. Seria essa parcela da classe, a liderança que guiaria os demais, segundo a dissertação. Para tanto, teriam criado uma rede de jornais, muitas vezes ligados a uniões e ligas operárias. Eles seriam o veículo pelo qual "a liderança operária orientava as massas trabalhadoras".

A utilização do jornal como veículo de comunicação foi de grande proveito para a organização da classe trabalhadora brasileira. Basta averiguar a intensa rede de jornais que surgiu com a fundação das ligas e uniões e a grande tiragem que esses jornais atingiam nos períodos que antecederam aos movimentos grevistas. Em todos os acontecimentos importantes que empolgaram os trabalhadores brasileiros o jornal mostrou-se o principal veículo de comunicação. Através de suas páginas a liderança operária orientava as massas trabalhadoras (FERREIRA, 1978, p. 15).

Consoante com a perspectiva já apresentada, Ferreira divide o movimento operário no Brasil em dois períodos distintos, sendo o segundo uma "evolução" do primeiro. Durante o século XIX teria havido um movimento "mutualista" menos politizado que "evoluíra", no início do século XX para um movimento mais politizado de "resistência". Os responsáveis por esta "evolução" teriam sido os intelectuais e os operários imigrantes.

Em sua dissertação sobre a imprensa negra no século XIX: De pele escura e tinta preta, defendida na Universidade de Brasília, Ana Flávia Magalhães Pinto (2006) também discute a dissertação de Ferreira (1978). Ao explicitar as diferenças entre imprensa negra e imprensa abolicionista, Magalhães Pinto nota que confusão semelhante não se dava entre imprensa negra e imprensa operária, mesmo diante da participação dos negros seja na produção de notícias, ou na massa para a qual poderia dirigir-se e envolver os impressos do mundo do trabalho. E critica o fato de Ferreira (1978) restringir o movimento operário e a imprensa operária à base de participação do imigrante europeu de marcada orientação anarco sindicalista.

Ana Flávia Magalhães Pinto demonstra, por outro lado, a presença negra nas lutas operárias oitocentistas. Toma como ícone, Manoel Querino, nascido na Bahia em 1851. Lá ele teria se envolvido com a luta operária como passo seguinte à emancipação dos trabalhadores escravizados. Querino, que atuou na Liga Operária Baiana (1874-1875) “(...) uma das primeiras cooperativas de trabalho do Brasil, composta basicamente por trabalhadores da construção civil (...)" (PINTO, 2006, p. 29), fundou também o jornal A Província, em 1887, a serviço da causa operária, e mais tarde $\mathrm{O}$ Trabalho, em 1892, “Atento à prevenção contra os políticos partidários (...)” (PINTO, 2006, p. 30).

A autora segue destacando outros negros, proeminentes figuras do jornalismo oitocentista como: José do Patrocínio, Luiz Gama e Machado de Assis, antes de apresentar a análise dos títulos da imprensa negra por ela estudados, quais sejam: O homem de cor ou O mulato; Brasileiro pardo; O cabrito; O Lafuente, no Rio de Janeiro, em 1833. O homem: realidade constitucional ou 
dissolução social, de Recife, em 1876. A pátria: órgão dos homens de cor, de São Paulo, em 1889. O exemplo, de Porto Alegre, em 1892. E O progresso: órgão dos homens de cor, de São Paulo, em 1899.

Ainda sobre a obra de Ferreira (1978), observamos que a autora destaca além dos jornais, outras iniciativas educacionais do movimento operário. Para ela, as sedes de ligas e uniões podem ser consideradas centros irradiadores da cultura operária. "Os imigrantes fundaram em cada associação escolas para alfabetização de adultos e escolas modernas para os filhos dos operários" (FERREIRA, 1978, p. 57). Mas, adotando o discurso de uma liderança operária - o espanhol Carlos Escobar - Maria Nazareth Ferreira destaca a gravidade do analfabetismo entre os trabalhadores. Escobar tivera frustrado seu plano de alfabetizar operários em São Paulo. Em artigo no jornal $A$ Questão Social, de primeiro de maio de 1896, o militante desabafava:

(...) consegui então que se criasse em Ribeirão Pires um curso noturno (na liga local) para adultos. Eu estaria a noite com os obreiros, ensinar-lhes-ia a leitura, falar-lhes-ia da questão social. Matriculei 14 obreiros. A minha primeira decepção foi encontrá-los com inteligência demasiado entorpecida... a minha segunda decepção foi verificar praticamente que esses homens não podem aprender a leitura nem as contas. Trabalham 12 horas por dia, a noite estão cansadíssimos. Não aturam meia hora de explicação. Lembro-me dos escritores anarquistas provando que a instrução não será para os operários, enquanto não houver redução nas horas de trabalho. E chego à conclusão de que o operário conservar-se-á inculto enquanto dominar o capitalismo. (FERREIRA, 1978, p. 58).

O discurso de Escobar seria uma constante até antes da década de sessenta do século XX, enquanto dominava a perspectiva marxista de cunho estruturalista, que defendia a rígida separação da formação social entre estrutura econômica e superestrura ideológica, sendo a segunda determinada pela primeira. Por esse prisma, enquanto dominasse o sistema capitalista, a mente trabalhadora estaria condenada à dominação, aos véus da ideologia e da ignorância expressos na passagem "o operário conservar-se-á inculto". Não se concebia uma cultura própria a esses sujeitos, mesmo porque os estudos culturais ainda não haviam se difundido. Segundo E. P. Thompson (1981) o termo "cultura" fizera falta ao próprio Marx, bem como a "experiência" seria termo ausente em sua obra, ela que mais tarde faria a ligação entre "um modo de produção altamente conceitualizado e abstrato dentro do qual o determinismo surge como absoluto, para as determinações históricas como exercícios de pressões, como uma lógica do processo...” (THOMPSON, 1981, p. 181).

Sem desconsiderar as razões expostas no trecho citado é preciso questioná-lo como fonte na qual Ferreira, talvez, tenha "confiado" um pouco além da conta. Seria preciso interpor ao desabafo de Escobar a problematização acerca de outras formas de leitura de mundo e saberes daqueles operários, além das possibilidades abertas a diferentes apropriações do ensino propagado pelas 
aulas noturnas facultadas a eles desde o Império (ainda que elas não representassem um acesso universal à instrução). O depoimento nos coloca diante do que Thompson (2002) afirma ser, como vimos no capítulo 2, a diferença de experiências da maior parte da classe operária e de suas lideranças que muitas vezes percebiam com desprezo as condutas e visões de mundo do operariado.

A crítica das fontes levada a cabo por Ferreira poderia ser mais incisiva ao discutir as possibilidades da imprensa para o estudo histórico. De acordo com outros historiadores, entende o jornal como importante fonte histórica desde que considerados fatores como "dependência econômica, mistura do imparcial e do tendencioso, do certo e do falso" (FERREIRA, 1978, p. 87). É neste momento que ela ameniza a perspectiva ao afirmar que "no caso da imprensa operária esse problema fica descaracterizado pelo fato de que ela sempre foi (...) totalmente desvinculada da ordem instituída. (...) É evidente que, mesmo nestas condições, os deslizes da parcialidade e do tendencioso existiram e precisam ser considerados...” (FERREIRA, 1978, p. 87). Porém, não se trata de deslizes da parcialidade e sim da impossibilidade de neutralidade num universo da classe extremamente heterogêneo, onde havia conflitos entre operários e por vezes ligações mais estreitas com representantes da própria ordem estabelecida ${ }^{74}$.

O debate acima proposto tem que considerar, antes de mais nada, o contexto de produção do trabalho discutido. E cabe ressaltar que o contato com a obra de Maria de Nazareth Ferreira foi de grande importância para o desenvolvimento do presente capítulo, a medida que estabelece o nexo entre classes trabalhadoras, imprensa e educação, associando estes três elementos a outras formas educacionais como escola, teatro, literatura, além de trazer valiosas informações estatísticas sobre jornais operários. Encontramos, ainda, visão consoante sobre o papel do jornalismo para além de documento de um determinado grupo social ou de uma época. "Sua importância pode ser encontrada também nos estudos da sociedade, como valioso instrumento de orientação coletiva; como um militante com certa prática na área notou: 'A missão do jornalismo não se limita, entretanto, a difundir ideias, a educar politicamente e atrair aliados políticos. O jornal não é somente um agente coletivo de propaganda, mas também um organizador social'.” (FERREIRA, 1978, p. $88)$.

Devemos acrescentar aos termos do nexo citado no parágrafo acima, as associações. $\mathrm{Ou}$ seja, a pesquisa aqui relatada, constatou estreita ligação entre educação, imprensa e associações no universo das culturas de classe trabalhadoras. Para além da expansão numérica paralela entre o fenômeno associativo e da imprensa operária, observamos que muitas características e conclusões formuladas a partir da análise das organizações trabalhadoras apresentadas no capítulo 2 também são válidas para os periódicos aqui estudados. Mesmo porque parte desses periódicos representava

74 Não pretendo entrar no mérito do tipo e propósito das ligações estabelecidas e não cabe um juízo moral sobre elas. 
órgãos de propaganda das associações, veiculava informações sobre elas, além de defender a importância e a expansão do movimento associativo.

A ligação entre periódicos e associações é destacada por historiadores preocupados com uma história social da imprensa. Segundo Morel,

(...) entre os atores que dão base ao periodismo estão: associações secretas, reservadas ou públicas que surgem já no século XVII e ganham novo impulso a partir da independência, com altos, baixos e uma explosão quantitativa a partir de 1831. (...) Havia associações com funções diversificadas: culturais, científicas, pedagógicas, por ofício, benemerentes e etc. A cada um desses grupos, apesar de alguma heterogeneidade e mudanças de posição, equivalem quase sempre publicações espalhadas pelas províncias e unificadas por determinadas bandeiras, interesses e palavras de ordem. (...) A imprensa constituiu-se como formuladora de projetos de nação distintos entre si (apesar de convergências) e de uma cena pública cada vez mais complexa da qual emergiam atores políticos diferenciados (MOREL, 2011, p. 26 e 42).

Na pesquisa documental ficou explícito que a edição de periódicos se constituía em política de várias organizações de trabalhadores. A Revista da Associação dos Guarda Livros representa um desses casos. Em seu número de 31 de janeiro de 1874 informa que sua criação significava “... o cumprimento de uma das disposições de seus estatutos e justo desejo de (...) contribuir e firmar o espírito de associação quase nulo neste país gigante...". Ela teria sido publicada tardiamente, prevista desde abril de 1869, realizada apenas em 1874, o que é atribuído ao "indiferentismo" e "falta de espírito de classe" dos guarda livros.

A estreita ligação com as associações de trabalhadores não se dá apenas à medida que alguns jornais são promovidos por elas. Também era comum a divulgação geral das atividades e documentos dessas organizações nas páginas dos periódicos que não se declaravam como órgão de qualquer associação. O Proletário, Hebdomadário artístico, literário e recreativo traz publicado o resumo de conferência promovida pela Liga Operária, além de atas do Clube Literário Gonçalves Dias. O Três de Abril abria espaço para comunicação da União Operária do Engenho de Dentro com seus sócios, transparecendo em suas páginas, até mesmo, as disputas internas àquela associação como na nota "Galvas (sic.) a Mostra", de 16 de abril de 1905, em que o editor do jornal e presidente da União Operária cita o caso de indivíduos expulsos pelos sócios em assembleia geral. Usa as seguintes palavras: “A União Operária do Engenho de Dentro, hoje mais que nunca, em pleno progresso, avisa a todos os consócios e ao operariado em geral, que não devem ligar importância às considerações que faz um velho demente, que foi eliminado por incapaz e má figura, conjuntamente com os seus sectários”.

Enquanto órgãos de associações, os jornais operários tinham funções como as narradas na 
“Carta Aberta à Diretoria do Centro dos Operários Marmoristas", publicada na edição de 1 de dezembro de 1906 de O Marmorista: seriam veículos do levantamento moral da classe, disporiam os espíritos à luta, informariam sobre os acontecimentos relacionados à associação.

Cumpre-me levantar aqui um voto de louvor, que, pela alevantada ideia de editar um jornal da classe, merecem não só aqueles que em tão boa hora tiveram essa feliz lembrança, como ainda a quantos a ampliaram com seu esforço prático.

Dedicando como ides fazer esse jornal a propagar o levantamento moral e material da classe, dispondo os espíritos para a luta, torna-se a publicidade do periódico uma das primeiras necessidades. É preciso porque a cada um de nós caberá um exemplar, no qual veremos consignados os acontecimentos sociais econômicos do operariado, assim como quando não tenhamos tempo de ir à nossa sede, em dias de expediente, o número a seguir nos porá ao correr de tudo.

No amplo universo da imprensa fluminense foram selecionados jornais e revistas com caráter manifestamente popular, especialmente voltados para o mundo do trabalho. É importante pontuar o volume de títulos e a impossibilidade de lê-los em sua totalidade.

\section{2- Caracterização dos impressos analisados}

Os títulos analisados compõem a tabela 5, apresentada a seguir, estruturada por informações mais ou menos fragmentadas em virtude do próprio caráter das fontes, a irregularidade de sua publicação e mais ainda de sua preservação. Estes jornais não tinham como objetivo a arrecadação financeira por vendas ou anúncios. É raro encontrar, neles, anúncios de produtos e serviços ${ }^{75}$. Quase sempre afirmavam que sobreviviam com dificuldade e pediam auxílio ao público leitor. A Revista da Associação dos Guarda-Livros era distribuída por diversas casas comerciais rogando-lhes o favor de subscrevê-la. Porém, “... não entrou nisso cálculo de interesse de colaboração, mesmo porque não temos a honra de ser jornalistas. Buscamos, é certo, cobrir as despesas de impressão com o preço da assinatura, porém apetecemos mais que nossa gazeta seja lida e apreciada pelo respeitável corpo de comércio" (Revista da Associação dos Guarda Livros. 15 de agosto de 1875). Enquanto $O$ Três de Abril informa aos associados da União Operária do Engenho de Dentro que a impressão do jornal não era custeada pelos cofres sociais e sim corria por conta de dois sócios signatários. De acordo com Morel,

O que se conhecia como imprensa periódica é bem diferente do que hoje se

75 Uma das exceções é o Jornal dos Tipógrafos que publicava anúncios a pedidos "mediante a retribuição usual nas mais folhas". Além de publicar dados sobre o comércio (importação e exportação), movimentos do porto, avisos da repartição de polícia; anúncios de leilões, vários anúncios de aluguel e compra de escravos. Os anúncios tomavam quase todo o jornal que foi criado, durante a greve dos tipógrafos de três grandes folhas diárias, com objetivo principal de suprir a falta destas. 
compreende como tal, inclusive em seu suporte físico: apesar de algumas iniciativas estáveis havia grande número de títulos efêmeros. Mesmo demandando alguns recursos financeiros, não era preciso ser muito rico para fazer circular um jornal que tinha formato pequeno, poucas páginas, com anúncios escassos. Tanto um jornal governista quanto um oposicionista tinham um alcance, em princípio semelhante. E não era necessário ser um privilegiado social para comprar eventualmente um exemplar cujo preço estava acessível até mesmo para um escravo de ganho que se interesse em sua leitura" (MOREL, 2011, p. 36).

Apesar dos custos da publicação das folhas não ser elevado, o que se observa na circunstância de serem editadas até mesmo com recursos de dois indivíduos trabalhadores, a falta de um financiamento substancial provocava a publicação com irregularidade ou desaparecimento de muitas delas em curto espaço de tempo. Fato tratado com ironia no cabeçalho d' $O$ Panificador que indica aparecer "quando pode", porém seu preço também seria “à vontade" por subscrição voluntária. Por esse motivo Força Nova lançava o apelo aos leitores: “Aos camaradas que julgam útil nossa propaganda pedimos que façam todos os esforços remetendo-nos suas contribuições pecuniárias o mais breve possível a fim de darmos regularidade à tiragem dessa folha" (Força Nova. 24 de julho de 1904).

É importante salientar que a mesma estratégia utilizada, no capítulo 2, para tratar das associações foi adotada para tratar dos jornais voltados para a classe trabalhadora, qual seja, uma entrada horizontal, compondo um quadro de informações a partir de um número relativamente grande de periódicos. Os objetivos e condições materiais excluíram a opção pelo estudo verticalizado, aprofundado de um ou outro título. Nesse sentido, os jornais foram utilizados como fonte e não tratados como objeto em sua materialidade, ainda que esta materialidade possa ser evocada em um ou outro instante na abordagem das formas de educar-se pela imprensa.

O recorte temporal utilizado seguiu aquele estabelecido no capítulo anterior, uma vez que a análise dos periódicos do mundo do trabalho também revelou o processo de transição já citado entre os dois momentos da história operária (sem perder de vista continuidades entre eles e a heterogeneidade de experiências existentes nos dois momentos). Nas últimas décadas do século XIX haveria um caráter mais mutualista das organizações, ações e culturas de trabalhadores, onde o conflito de classes convivia com a perspectiva da negociação e proteção buscada junto a poderes paternalistas. Já nos primeiros anos do século XX, as classes trabalhadoras se encontravam mais agregadas, com contornos mais delimitados pelo e para o embate direto com capitalistas e poderes do Estado. A partir de 1917, entretanto, esse formato ainda mudaria, segundo Batalha (2004), das associações de ofício para os grandes sindicatos industriais. Sem a pretensão de tratar de organizações sindicais, esta tese marca o último periódico no ano de 1914. 
Tabela 5: Periódicos da imprensa operária analisados

\begin{tabular}{|c|c|c|c|c|}
\hline Nome do impresso & Data & $\begin{array}{l}\text { Periodici } \\
\text { dade }\end{array}$ & Editor & Local \\
\hline $\begin{array}{l}\text { 1- Jornal dos } \\
\text { Tipógrafos }\end{array}$ & $\begin{array}{l}\text { Janeiro } \\
\text { a Março } \\
\text { de } 1858\end{array}$ & Diário & $\begin{array}{l}\text { Imperial Associação } \\
\text { Tipográfica Fluminense }\end{array}$ & Município da corte \\
\hline 2- O Artista & $\begin{array}{l}1870- \\
1871\end{array}$ & & $\begin{array}{l}\text { Os engenheiros: Tenente } \\
\text { Coronel Fernando Luiz } \\
\text { Ferreira; Dr. Miguel } \\
\text { Vieira Ferreira; Dr. Luiz } \\
\text { Vieira Ferreira e Dr. } \\
\text { Joaquim Vieira Ferreira }\end{array}$ & $\begin{array}{l}\text { Município da corte e } \\
\text { Niterói }\end{array}$ \\
\hline $\begin{array}{l}\text { 3- Revista da } \\
\text { Associação dos } \\
\text { Guarda Livros }\end{array}$ & $\begin{array}{l}1874 \mathrm{e} \\
1875\end{array}$ & Mensal & $\begin{array}{l}\text { Associação dos Guarda } \\
\text { Livros }\end{array}$ & Município da corte \\
\hline $\begin{array}{l}\text { 4- Gazeta dos } \\
\text { Operários }\end{array}$ & $\begin{array}{l}\text { Dezemb } \\
\text { ro de } \\
1875\end{array}$ & Diário & Propriedade de Operários & Município da corte \\
\hline 5- O Proletário & $\begin{array}{l}1877- \\
1878\end{array}$ & Semanal & $\begin{array}{l}\text { “.. alguns poucos } \\
\text { artistas..." }\end{array}$ & Município da corte \\
\hline $\begin{array}{l}\text { 6- A Consciência } \\
\text { Nacional. }\end{array}$ & \begin{tabular}{|l|}
2 de \\
dezemb \\
ro de \\
1877
\end{tabular} & & & Município da corte \\
\hline 7- O Socialista. & 1878 & Semanal & Clube Socialista & Município da corte \\
\hline 8- Gazeta Operária & $\begin{array}{l}\text { Janeiro } \\
\text { de } 1881\end{array}$ & $\begin{array}{l}\text { Quartas- } \\
\text { feiras e } \\
\text { sábados }\end{array}$ & & Município da corte \\
\hline 9- A Revolução ${ }^{76}$ & \begin{tabular}{|l|} 
Abril e \\
Maio de \\
1881 \\
1882
\end{tabular} & $\begin{array}{l}\text { Quartas- } \\
\text { feiras e } \\
\text { domingos }\end{array}$ & Favila Nunes & Município da corte \\
\hline 10- Lincoln & \begin{tabular}{|l|} 
Janeiro \\
de 1883
\end{tabular} & & $\begin{array}{l}\text { Clube Abolicionista } \\
\text { Gutemberg }\end{array}$ & Município da corte \\
\hline 11- Gazeta Suburbana. & $\begin{array}{l}25 \text { de } \\
\text { março } \\
\text { de } 1884\end{array}$ & & & Município da corte \\
\hline $\begin{array}{l}\text { 12- Vinte e Cinco de } \\
\text { Março }\end{array}$ & \begin{tabular}{|l|}
25 de \\
março \\
de 1884
\end{tabular} & & $\begin{array}{l}\text { Arthur José } \begin{array}{r}\text { Ferreira, } \\
\text { funcionário do Diário } \\
\text { Oficial }\end{array} \\
\end{array}$ & Município da corte \\
\hline 13- O Domingo & 1888 & & Órgão da classe caixeiral & Município da corte \\
\hline
\end{tabular}

76 O jornal "A Revolução" possui duas épocas, a primeira em abril de 1881 quando para de ser editado e retorna em 1882. 


\begin{tabular}{|c|c|c|c|c|}
\hline 14- Echo Popular & 1890 & & Luiz da França e Silva ${ }^{77}$ & Distrito federal \\
\hline 15- O Panificador & \begin{tabular}{|l|} 
Janeiro \\
e \\
Fevereir \\
o de \\
1900 \\
\end{tabular} & Irregular $^{78}$ & $\begin{array}{l}\text { Sociedade Cosmopolita } \\
\text { Protetora dos Empregados } \\
\text { em Padarias }\end{array}$ & Distrito federal \\
\hline 16- Força Nova & $\begin{array}{l}24 \text { de } \\
\text { julho de } \\
1904\end{array}$ & & & Distrito federal \\
\hline 17- O Três de Abril & \begin{tabular}{|l|} 
abril e \\
setembr \\
o de \\
1905 \\
\end{tabular} & Semanal & $\begin{array}{l}\text { Órgão da União Operária } \\
\text { do Engenho de Dentro }\end{array}$ & Distrito federal \\
\hline 18- O Marmorista & \begin{tabular}{|l}
1 de \\
dezemb \\
ro de \\
1906 e \\
1 de \\
janeiro \\
de 1907
\end{tabular} & Mensal & $\begin{array}{l}\text { Centro dos Operários } \\
\text { Marmoristas }\end{array}$ & Distrito federal \\
\hline 29- A Redenção ${ }^{79}$ & \begin{tabular}{|l}
25 de \\
março \\
de 1914 \\
a 25 de \\
julho de \\
1914
\end{tabular} & Mensal & $\begin{array}{l}\text { Administração da } \\
\text { Penitenciária do Estado } \\
\text { do Rio de Janeiro }\end{array}$ & Niterói \\
\hline
\end{tabular}

De acordo com os dados expostos na tabela 5, foram selecionados 29 títulos entre órgãos de propaganda de associações operárias e publicações com público mais amplo, destinadas a toda classe trabalhadora, como O Artista; A Revolução; Força Nova; etc. Como observado no capítulo 2 sobre as associações, também a maioria dos jornais eram editados na cidade do Rio de Janeiro, sendo a única exceção A Redenção, periódico produzido na Penitenciária do Estado do Rio de Janeiro, localizada em Niterói. Este não destoava, apenas, pelo local de edição, mas pelo próprio caráter da publicação, voltada para os trabalhadores ali detidos, era produzida pela diretoria da penitenciária e estava de acordo com a ordem político social vigente. Foi inserido na série documental por se declarar voltado para aqueles trabalhadores, por tematizar o trabalho e por servir de contraponto ideológico aos demais.

Nas próximas páginas se tornará mais explícita a discussão sobre a heterogeneidade

77 Seu diretor era Luiz da França e Silva e ao que tudo indica representava o Partido Operário do Brasil.

78 "Aparece quando pode", era o que se lia no próprio jornal sobre sua periodicidade.

79 Jornal da Penitenciária do Rio de Janeiro, faz um contraponto ao caráter dos outros periódicos. Se dirigia aos presos com intuito de regenerá-los para a vida de trabalhadores honestos. 
existente no universo que estamos denominando como imprensa operária. Ele abarcaria, ao mesmo tempo, tipógrafos ou guarda livros, ofícios que requeriam maior grau de instrução e conferiam status social mais elevado e padeiros, cujo trabalho era predominantemente manual. Quanto mais recuamos no tempo, apresenta-se uma maior dificuldade em encontrar publicações escritas por categorias de trabalhadores ligadas ao trabalho predominantemente manual. A tabela nos mostra que, no século XIX, as associações que editavam jornais eram as de tipógrafos, guarda livros e caixeiros, porém o fato de outras categorias não publicarem seus periódicos, não quer dizer que não lessem (de diversas formas) as publicações da imprensa operária tais como: O Proletário, Gazeta Operária, Gazeta Suburbana, etc.

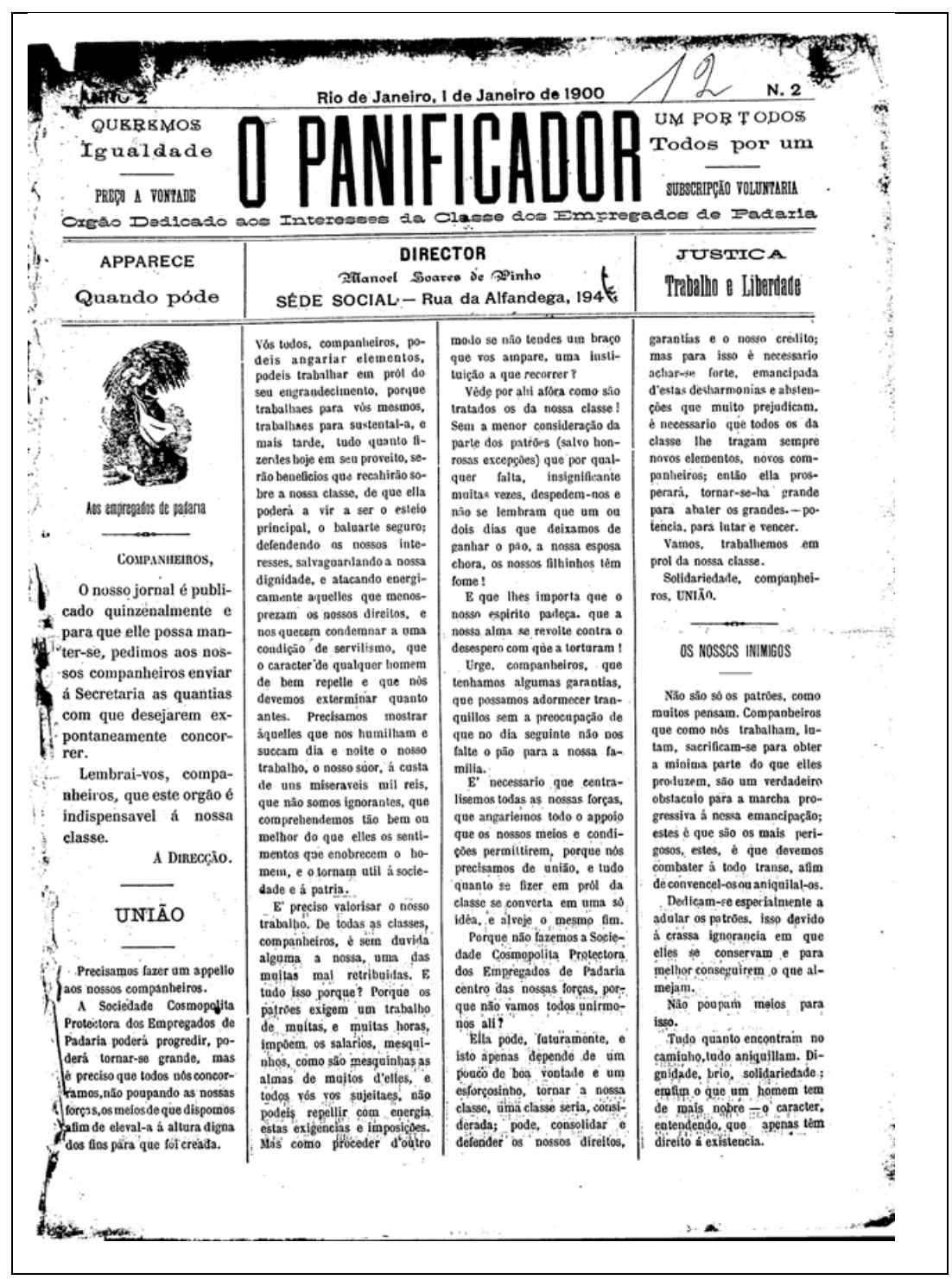

Figura 1- No cabeçalho de $O$ Panificador, de 1 de janeiro de 1900, uma referência bem humorada à irregularidade da publicação: "Aparece quando pode".

Ao escolher publicações que delimitam as classes populares como público, especialmente no 
mundo do trabalho, tive como intenção principal observar a que tipo de leitura e a que universo de ideias esses sujeitos estavam expostos. Possibilidade corroborada pela perspectiva de Barbosa (2010) que, apoiada em Barthes e Darton afirma:

O leitor, tal como o autor, implicado no texto, também é construído no e pelo texto, por essa razão, lendo os textos que eles leram podemos nos aventurar, no universo desconhecido de suas leituras e interpretações. (...) As memórias, romances, contos e crônicas são ricos em indicações que possibilitam o mapeamento desse leitor e dessas leituras de outrora. Não apenas os ricos industriais, os políticos, os fazendeiros, público tradicional do Jornal do Commercio, mas os trabalhadores, empregados do comércio, ambulantes, vendedores, militares de baixas patentes, funcionários públicos, mulheres, presidiários, leitores habituais ou esporádicos dos jornais que se autodenominam populares" (BARBOSA, 2010, p. 203 e 204).

Além de pensar a imprensa como fonte privilegiada de informações sobre a vida da corte e da Província Fluminense, também procuro considerar o valor educativo/formativo que ela representava para o público leitor. Considerando que o jornal, ou mesmo a revista, tem uma circulação mais ampla e democratizada que o livro, seja por seu formato, linguagem ou custo, dimensionaremos seu papel educativo para essa parcela da sociedade. Entretanto, não se trata aqui de quaisquer jornais ou revistas ou de quaisquer temáticas por eles abordadas. São aqueles que nos permitem verificar as manifestações das classes trabalhadoras acerca de suas experiências e concepções educacionais.

Os títulos escolhidos permitiram compreender o uso da imprensa como uma ferramenta pelas classes populares em sua experiência educacional. Tal afirmação é possível, por um lado, porque estes sujeitos são escolhidos como público, erigidos assim em interlocutores legítimos. Ainda que, como veremos a seguir, insista-se em sua apatia, inércia ou inconsciência, os editores só se dirigem a eles porque creem poder "acordá-los". Por outro lado, os próprios editores se auto definem como pertencentes à classe de artistas e operários.

Em suas páginas encontramos a positividade da instrução, a valorização da escola, mas também a valorização da capacidade do trabalhador em se instruir fora dela. Encontramos, ainda, a relação com o associativismo, tanto uma ligação direta, por representarem órgãos de propaganda de diversas associações, algumas delas tratadas no capítulo 2, como pelo incentivo dado a esta prática.

Antes de discutir a relação mais direta, objetivo central do presente capítulo, entre imprensa operária e educação expressa nos "recursos pedagógicos" e as concepções sobre a educação para o povo veiculadas no conjunto de jornais analisados é importante caracterizá-los brevemente. Estes periódicos, além de desenvolverem seu próprio programa em textos mais densos de análise e opinião, procuravam noticiar os acontecimentos cotidianos da cidade. Traziam, ainda, variedades, com objetivo de "ilustrar" e entreter o leitor, tais como: biografias, folhetins, charadas, poemas. 
Geralmente, em seus primeiros números encontramos o editorial, onde se divulga o programa do jornal. Num momento em que a imprensa era considerada uma tribuna, uma arena de debate político, tal tomada inicial de posição era considerada muito importante.

"Tribuna da humanidade no caminho do progresso e da liberdade", observando a autoimagem da imprensa, encontramos representações contraditórias, pois também se usava a imagem de "arena de lutas" para se referir a ela. Segundo O Proletário (7 de outubro de 1877), "a imprensa para nós é um gládio". Dessa forma os redatores alternavam a representação da defesa dos interesses das classes trabalhadoras entre formas legais e formas "violentas". O Proletário (17 de novembro de 1877), em artigo que pede o auxílio da classe para a manutenção de sua missão, é emblemático: “O jornal é o advogado dos direitos do povo, e não é só isso, é também uma trincheira difícil de romper para aqueles mandões que sofismática e calculadamente tentam executar leis absurdas". Caso não fosse suficiente ir aos tribunais, concebia, ao menos retoricamente, a ida às trincheiras. Certamente essas são metáforas usadas pelos redatores, o que é, inclusive, um traço importante da produção textual aqui analisada. Porém, a escolha da metáfora a utilizar não é por si mesma, neutra e indiferente.

O Socialista identifica-se como "órgão de pugilo de homens convictos e fortes". Esses homens não seriam os trabalhadores em geral, mas sim intelectuais postos ao lado das classes operárias, sujeitos que se colocavam num papel de liderança, de vanguarda. Eles combateriam "em favor dos párias sócias, os operários, uma classe lembrada pelos grupos políticos de nossa pátria, nos momentos em que precisam de vitória; e por eles esquecida na hora gloriosa em que se apossam do poder".

A maioria dos jornais e revistas analisados não possuem imagens, apenas textos corridos. Temos a exceção n'O Artista, cujo objetivo era propriamente instrutivo, havia desenhos de máquinas e ilustrações de processos produtivos, mas não eram em grande número. Encontramos em O Proletário, O Socialista e Gazeta Operária anúncios comerciais e seções abertas à manifestação do público: cartas, recados, reclamações. 


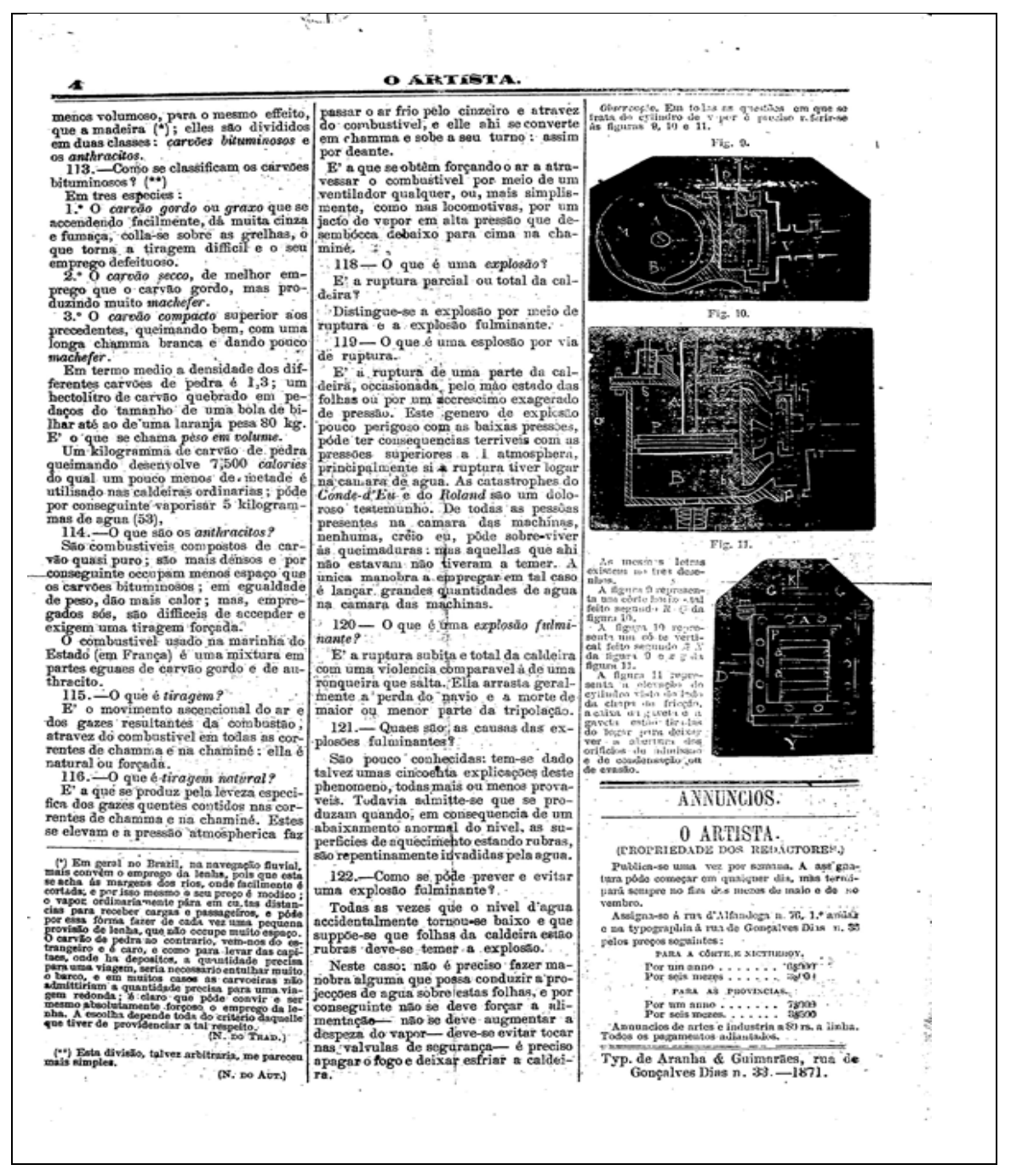

Figura 2- Ilustrações do artigo "Catechismo de Máquinas a Vapor" por C. H. Bellanger, em $O$ Artista, de 29 de janeiro de 1871.

As colunas da maioria dos periódicos aqui estudados propunham-se a abrigar denúncias dos arbítrios sofridos pelos "colegas operários". Nesse sentido, faculta-se: "Para esse fim, podem dirigir suas reclamações em carta fechada à Rua Teófilo Ottoni, número 151, livraria do Sr. A. T. de Castro Dias, subscritas à redação do Proletário". Força Nova solicitava aos trabalhadores de todas as categorias que tivessem queixas a fazer se dirigir à redação do jornal onde encontrariam pessoas habilitadas para registrá-las. Não só denúncias, mas todo tipo de recados dos leitores encontravam espaço naquelas páginas, deixando-nos perceber uma intensa interlocução entre jornais e público. $O$ Socialista (20 de julho de 1878) possuía uma seção dedicada aos recados, onde se publica: “Um pai de família pede escadas nos centros das arquibancadas [referindo-se as condições de certo estádio]”; "Pede-se providência contra a prostituição"; "Denuncia-se golpista que agora é funcionário em delegacia". Gazeta dos Operários (8 de dezembro de 1875) apresenta serviço de utilidade pública de forma bem humorada, procurando surtir efeito a denúncia dos moradores do morro de Paula Mattos que “... já estão sentindo falta de água. Água, Sr. Ministro. Assinado: A Sede”. 
Quanto ao pertencimento social dos redatores, nota-se que procuram se aproximar o máximo possível do público leitor, talvez em busca de maior legitimidade para falar por ele. O Proletário (7 de outubro de 1877) afirma que "seu aparecimento na imprensa é o resultado da firme vontade de alguns poucos artistas que desejam melhorar sua condição social pela instrução”. A Consciência Nacional pretende falar pelo operário, artista nacional, mas não fica claro o pertencimento do redator que nem mesmo usa o recurso de Gazeta Operária ao pronome "nós" para se referir à classe operária. Este último se define como manifestação dessa classe e apesar do redator não deixar explícita sua identidade podemos inferi-la em frases como: "E nós que constituímos parcela desse grande todo e que representamos a maioria - o povo”. Já $O$ Artista não deixa dúvidas sobre quem são seus redatores. Na primeira página encontramos a informação de que é "propriedade dos redatores, os engenheiros: Tenente Coronel Fernando Luiz Ferreira; Dr. Miguel Vieira Ferreira; Dr. Luiz Vieira Ferreira; e Dr. Joaquim Vieira Ferreira". Em algum dos textos do jornal cita-se o Tenente Coronel Fernando Luiz Ferreira como "engenheiro, artista ele mesmo".

Nos periódicos de fins do século XIX e, principalmente nos primeiros anos do XX, os redatores fazem questão de registrar seu pertencimento de forma bem explícita, como em Força Nova (24 de julho de 1904) que afirma ser “... dirigido exclusivamente por homens trabalhadores, sendo, porém, colaborado por todos que se interessam pela questão social, não cedendo nunca suas colunas para discussões pessoais". Supomos que os redatores daqueles jornais que são órgãos de propaganda de associações de ofício já teriam seu pertencimento social demarcado por esse mesmo fato. De qualquer forma, a luta de classes é expressa em todo o conjunto analisado uma vez que a imprensa, nesse momento, especialmente aquela voltada para as classes trabalhadoras, era uma imprensa de opinião, que incluía em seus objetivos a propaganda ideológica. São constantes as imagens de conflito entre ricos corruptos e pobres que "ganham o pão com o suor de seu rosto"

Politicamente encontramos redatores críticos ao status quo, à classe política no poder por corrupta e desgastada, ou declarando-se neutros, desligados das questões partidárias. O Proletário (7 de outubro de 1877) trata os governantes por "camaleões políticos elevados às altas regiões do funcionalismo, magistratura e representação nacional". Considera que o poder pouco a pouco solapa os homens públicos e instituições, porém acredita em um tempo mítico quando havia bons políticos defensores dos interesses da nação, ao contrário do momento atual em que "não se trata mais nessa casa [Parlamento] do bem comum do povo. O interesse individual é a divisa desses senhores que dirigem a grande nau do Estado". Por outro lado, defende o progresso da nação, a cidadania, bem estar, instrução, proteção para o povo e moralidade. Em sua opinião, concorreria para tudo isso uma representação operária no Parlamento inexistente até então. "Só lançarmos um golpe de vista para a

80 O Proletário. 
representação nacional, ficamos maravilhados, porque entre os 120 lugares do Parlamento não encontre o operário uma cadeira para si, tendo, no entanto, parte ativíssima nos comícios eleitorais". Essa representação operária seria uma alternativa à "camarilha calabrense que tudo promete e nada faz".

A Consciência Nacional (2 de dezembro de 1877) segue o mesmo tom de ataque ao regime instituído, mas acrescenta às suas críticas uma forte coloração nacionalista, considerando o reinado de Pedro II como um reinado estrangeiro. "Deve ser mais: um protesto consciente e vigoroso do sentir popular, convencida e desenganada a nacionalidade brasileira da prestabilidade moral de uma instituição exótica e anacrônica aí artificiosa e fraudulentamente enxertada, em tronco que a repelia...”. Porém o jornal também não se ligava a nenhum dos partidos existentes considerados corrompidos. Nenhum deles representaria verdadeiramente o operário nacional. Pelo contrário, diz que "o trabalho mecânico que se representa no pessoal operário, da fortuna ou infortúnio do qual ninguém cogita se não para vexá-lo e explorá-lo em todos os períodos da vida pública, e só invocado nominalmente nos dias do nominal exercício da ridícula suposta soberania popular". Apesar do discurso político profundamente crítico, deseja evitar o que chama de "desastres sociais", como uma revolução social, talvez, que poderiam ser causados pelo "desespero das classes laboriosas".

Semelhante ao periódico acima referido, Gazeta Operária não se vincula aos partidos existentes. Fala ao povo e pretende contar apenas com a força deste na luta por seus direitos. Declara-se neutra nos interesses partidários e crenças políticas e em vez da luta de classes opta pela participação na vida política do país ao lado das outras corporações. Seu posicionamento político mais marcante diz respeito à ferrenha crítica feita à reforma eleitoral de 1881 por excluir a maior parte do povo do pleito.

Mas, qual, engano; o Sr. Saraiva é de um tino... A prova é que fez passar o artigo $8^{\circ}$ enquanto excluía a maior parte dos legítimos cidadãos que mais concorrem para o progresso e engrandecimento da pátria, pretextando a inconsciência com que exerciam o sacratíssimo direito de cidadãos. (...)

O proletariado, único mercadejador da consciência, na opinião de S. Ex. o Sr. conselheiro Saraiva, está para todo sempre condenado e despojado do supremo direito de cidadão!...(...)

Acabaram-se os capangas, os fósforos jamais terão extração e as baionetas do governo não farão correr mais o sangue do turbulento, inconsciente e miserável mercadejador do voto, o operário!...(...)

Concluiu, finalmente, V. Ex. a sentença que há muito sonhava para lavrar sobre as classes menos favorecidas e sobre o povo pobre - A Reforma Eleitoral!

De modo que só os Srs. proprietários e capitalistas são os considerados cidadãos. E podem gozar dos direitos que lhes são facultados pela reforma eleitoral! (...)

Pois bem, Sr. conselheiro. V. Ex. que passa em toda sua carruagem pelas ruas da cidade, lançando olhares para as multidões, encontrará muitos operários pobres, mas honrados, porque tem a consciência sã e o caráter nobre, não estão ainda 
corrompidos pelo vício torpe da bajulação como aqueles que descem ao balcão da venalidade, olvidando os mais sacrossantos princípios da sociedade e da natureza, alugando a consciência podre para empolgar as altas posições sociais .

É necessário, pois, que V. Ex. e todos quantos se acham colocados nas altas posições sociais, compreendam que o operário é um homem que tem um cérebro que pensa e não uma máquina...

O operário de 1881 não é o mesmo operário de 1850 nem de 1860 que só cuidava em trabalhar, comer e dormir.

O operário de 1881 trabalha, come, lê folhas diárias, vai ao teatro, estuda nas aulas noturnas, desenvolve seu talento em reuniões literárias, nas imprensas e nas tribunas populares, inocula no coração os verdadeiros germens das doutrinas sociais e não deixa passar impunemente as afrontas que lhe são feitas, aceita sempre o reto, quando lhe é atirado em face, porque conhece o que é reação (Gazeta Operária. 12 de janeiro de 1881).

A justificativa para exclusão do operário bem como da maior parte da população, na reforma que aumentou a renda que habilitava a votar ao passo que instituiu o critério de alfabetização para o voto era a necessidade de elevar a capacitação, e a consciência política dos votantes. A resposta do redator da Gazeta à tal justificativa é uma excelente oportunidade para percebermos as disputas políticas em torno do "capital cultural" das diferentes classes da sociedade e as representações em torno dos saberes, educação e instrução dessas classes. Primeiro argumento: seria o operário o único a mercadejar sua consciência? Segundo, enquanto suprime o direito de voto do operário, nada é feito contra outros graves problemas que acometiam as eleições como os capangas, a violência, a repressão expressa pelas "baionetas do governo".

Ao longo do artigo, a divisão de classes e seus efeitos políticos se estabelecem com nitidez: concretizara-se o desejo do Sr. Saraiva, chefe do gabinete ministerial responsável pela reforma - só os "senhores proprietários e capitalistas são considerados cidadãos". Porém, a reação se esboçaria em função da injustiça, já que se caçara o direito de sujeitos "pobres, mas honrados". Se esboçaria ainda, porque o operário é um ser pensante. E não se trata de um operário atemporal, mas sim de uma classe que viu mudanças, progressos no campo do acesso ao conhecimento letrado, desde mais ou menos 1860. É um operário que vem se educando por diversos meios, dentro ou fora da escola: nas aulas noturnas, mas também nas folhas diárias, no teatro, nas imprensas, nas reuniões literárias.

A crítica ao governo e a defesa dos interesses das classes trabalhadoras eram feitas a partir de diferentes matizes ideológicos mais ou menos definidos. Temos O Socialista e Echo Popular como exemplos de periódicos que se declaravam defensores do socialismo, enquanto Força Nova e A Revolução filiavam-se ao anarquismo, mantendo-se de fora das disputas eleitorais. Porém, havia os casos em que alguns órgãos de organizações de trabalhadores, como os guarda livros e tipógrafos, veiculavam ideias consoantes ao liberalismo, ainda que não se declarassem liberais.

A Revista da Associação dos Guarda Livros (30 de abril de 1874), apesar de dizer-se 
politicamente neutra, critica a doutrina econômica do governo pelo ponto de vista do liberalismo econômico. Segundo aqueles profissionais que se reuniam em associação com o fim de estudar o funcionamento do comércio no país, o governo não procurava atender os interesses econômicos do povo. Não apenas o comércio, mas a indústria, as letras, artes e ofícios e, morbidamente, a lavoura, estavam desprotegidos pelos poderes públicos.

A doutrina econômica da administração pública é entre nós uma, única, imutável: a elevação dos tributos como único meio meio para elevação das rendas do Estado. (...) Se repararmos para o comércio vemos que nenhum princípio, nenhum espírito liberal e protetor domina a administração pública, com intuito de fazê-lo desenvolver, crescer e nobilitar-se; pelo contrário, só a prevenção, a desconfiança, a suspeita se denunciam dos atos dela fazendo recair sobre ele pesados tributos e fatigantes e embaraçadoras formalidades fiscais...

Os altos impostos não pesariam apenas sobre os produtores e comerciantes, mas principalmente sobre "o consumidor pobre que constitui a maioria do povo". Segundo o redator, a criação de novas taxas e o aumento das existentes deu-se em função da Guerra do Paraguai. Usando, porém, a lógica, argumenta que, cessada a guerra, deveriam sessar as taxas.

Por outro lado, os poderes públicos devem convencer-se do erro econômico e político que cometem onerando com altos tributos as fontes produtoras do país, e abusando da mansuetude e ignorância do povo que tudo suporta silenciosa e resignadamente; porquanto, quando por tal meio o erário venha a nadar em dinheiro, o que em todo caso não será duradouro, os magnatas terão também grossas propinas, haverá mais calor bélico nos governos e as despesas improdutivas serão espantosamente aumentadas, mas o povo!... o povo afogar-se-á na miséria e as fontes emanadoras por fim serão exaustas! (Revista da Associação dos Guarda Livros. 30 de abril de 1874).

$\mathrm{Na}$ continuidade da interposição de argumentos lógicos sobre a política econômica do império, os guarda-livros representavam-se como capazes de influenciar o Estado, aconselhando os poderes públicos e sugerindo modelos de desenvolvimento como nas medidas econômicas liberais tomadas pela Inglaterra e Estados Unidos. Diferente de outras associações que conclamam os operários ou o povo, os guarda livros dialogam com o Estado procurando "empurrá-lo" a rumos de mudanças na ordem vigente, já que seriam os governos, guias de um povo "ignorante e manso" do qual não deveriam abusar.

No artigo "Conferências Públicas", de 30 de junho de 1874, percebemos a ambiguidade da concepção de "povo" dos guarda livros. Faziam parte de seu circuito intelectual, parlamentares e doutos como Ferreira Viana e Duque Estrada, oradores nas tais conferências públicas sobre temas como "... o grande chanceler francês, Francisco D'Aguesseau" ou “... O Prometeu, de Ésquilo". As falas de tais conferências tiveram lugar em instituição chamada "Escola do Povo", no edifício "Ao 
Povo o Governo". O que nos indica a contradição entre a generalização da palavra contida no "povo ignorante e manso" e o caráter restritivo que ela assume ao requerer "para o povo o governo". Essa pretensão fazia parte de um discurso idealista liberal que aparece explicitamente em artigo transcrito do Echo Americano sobre a imigração, manifestando a “... convicção de que os fatos que se realizam espontaneamente, sem intervenção de autoridades nem governos, são mais fecundos e proveitosos por serem os mais naturais".

Esta filiação ideológica pode ser, em parte, entendida como função do pertencimento social dos guarda livros, profissionais liberais, dedicados ao chamado "trabalho intelectual". Ainda que seja uma categoria heterogênea, trabalham estreitamente ligados aos patrões, enquanto o sucesso de sua atividade tem a ver com o sucesso do desenvolvimento comercial, na prática, nos moldes capitalistas. No artigo sobre o falecimento de um dos membros da associação, a revista nos dá uma pista sobre a profissão dos guarda-livros que nos permite associá-los a administradores, mas também a economistas ${ }^{81}$. Segundo o artigo, Bernardo de Souza Franco era:

Liberal em política como em ciência econômica e religiosa, e sobretudo o mais adiantado economista do Brasil, Souza Franco deixa um vácuo que dificilmente poderá ser preenchido nas fileiras dos operários das grandes ideias. (...) vindo d'entre o povo e elevado pelo seu esforço e talento e pela sua dedicação aos interesses públicos, à mais eminente posição social pelo voto do povo e do monarca que o condecorou ultimamente com o título de visconde (Revista da Associação dos Guarda Livros. 15 de maio de 1875).

Motivada ou não por divergências político-ideológicas, da mesma forma que entre as associações, a imprensa voltada para os trabalhadores apresentava, além da diversidade em seu universo de sujeitos e opiniões, conflitos e disputas entre seus periódicos. A oposição mais comum e esperada se dava entre as folhas ligadas às classes operárias e a grande imprensa diária com fins mercantis, vinculadas às empresas e ao poder governamental. Entretanto, O Proletário, (17 de novembro de 1877) em sua rixa com União do Povo, utiliza-se da comparação com a grande imprensa para desmoralizar aquele periódico que, a princípio, seria seu par. A União do Povo os teria chamado de "preguiçosos, de doutos, de vizinhos de sábios universais, etc, etc". Ao que responde $O$ Proletário compreendendo que "a ilustrada redação teve origem no mercantilismo e que sua lógica é a do algarismo, e por isso o tempo que leva a discutir conosco, falta-lhes para coisas mais proveitosas, por isso a deixamos em paz para explorar companhias Garys e outras, e também ser eco de nossa imprensa diária”. Essa mesma grande imprensa que, segundo O Socialista (3 de agosto de 1878), “com raras exceções, apinham-se nas ante salas ministeriais e aí mendiga migalhas que caem das mesas dos ministros".

O fato de se oporem à grande imprensa diária não impede esses periódicos de reproduzirem

81 A definição mais comum da função exercida pelos guarda-livros é a que a assemelha a atual função de contador. 
notícias veiculadas por aquela. Melhor dizendo, as notícias não eram simplesmente "reproduzidas", mas sim ressignificadas, uma vez que não deixam de ser comentadas. É o caso da denúncia de violência policial que lia-se "na Gazeta de Notícias de ontem", a que O Proletário (2 de dezembro de 1877) interpõe sua reiterada crítica à arbitrariedade policial.

Ontem, pelas 10 horas da manhã, em frente à Estação do Mangue, uma autoridade policial no exercício das suas funções, esbofeteou um preto que lhe foi apresentado preso só porque este não tirou o chapéu quando chegou à sua presença.

Este fato reclama a séria atenção das autoridades superiores.

Vai sem comentários.

Não é essa a primeira vez que a polícia do Sr. Dupin pratica dessas brilhaturas. São frutas do tempo, como dizia o Constitucional de catoníssima memória; le monde marche disse Peletan, e desde caceteiro e a flor da gente que se assentavam nas bancadas da temporária até o subdelegado que espanca cidadãos, ou a autoridade que no exercício de suas funções espanca presos, caminha-se gradativamente.

E: ave César.

Apesar de anunciar que o artigo iria "sem comentários", não se furta a debater o caso diretamente com o chefe de polícia, de quem cita o nome e ironiza sua prática de "brilhaturas". Ao analisar a notícia não restringe o fato à sua pontualidade, seriam "frutas do tempo", o uso de violência generalizada, tanto de "caceteiros", "flor da gente", ou "autoridades" não só contra presos, mas também contra cidadãos.

As divergências e conflitos entre periódicos voltados para trabalhadores existiam em uma conjuntura na qual os mesmos desenvolviam redes e apresentava traços de uma cultura comum, parte das culturas de classes referidas no capítulo 2. Muitas folhas apresentavam seu agradecimento pelo recebimento de outras. O Proletário recebe e agradece: “A coleção do Contemporâneo; o último número do Psit; A República; O último número de Comédia Popular; o primeiro número da Gazeta Semanal publicada nessa Corte; O último da Escola; o Guaratinguetense; um opúsculo intitulado Cenas verdadeiras". Além da circulação de jornais, havia o consentimento da transcrição e publicação de textos de uns pelos outros. $O$ Três de Abril agradece “... à ilustrada redação d' $O$ Operário de Juiz de Fora a publicação desse belo artigo que com a devida vênia transcrevemos gratíssimos. É essa a missão da imprensa operária - guiar, aconselhar sempre...”. De uma ou outra forma, muitos periódicos faziam propaganda de seus correlatos. Força Nova indicava: O Livre Pensador; O Amigo do Povo. Periódico Semanal de Propaganda Libertária; Despertar. Periódico Semanal Anarquista, entre outros.

Os programas e posicionamentos políticos descritos encontram coerência com o público para qual são destinados os jornais, a quem visam sensibilizar, representar, educar. Ao mesmo 
tempo em que escolhem os sujeitos para quem dirigem seu discurso, apontam outros em posição conflituosa. É o caso d' O Proletário que se destina ao - operário, proletário, povo, homem livre - a quem opõe, de certa forma, as carreiras científicas, os empregos públicos e os políticos. A Consciência Nacional defende os operários, artistas mecânicos nacionais diante das letras, ciências, comércio, indústrias artificiais, funcionalismo e estrangeiros. Já $O$ Socialista fala ao povo, aos parias sociais, operários contra as classes privilegiadas, classes predominantes. O Artista, apesar da categoria social expressa no nome, pretende educar e instruir os artistas, mas não é marcado por forte pertencimento de classe, sua causa não é a classe, mas a instrução.

Ao falar para as classes populares os redatores dos periódicos estudados colocam-se à distância, em certos momentos objetivando-as e nos deixando perceber em suas páginas as concepções que possuíam sobre "o povo", "os operários", "proletários", “artistas” ou demais faces desse complexo conjunto. Para $O$ Proletário (7 de outubro de 1877), seu público apresenta-se como indiferente às questões políticas e sociais. Esta indiferença era atribuída, porém, ao monopólio da política por sujeitos corruptos. Assim o periódico viria auxiliar um povo, a princípio sem voz, falando por ele. O grande problema desse povo, desse operariado seria, então, a apatia, a inércia, a descrença, a indiferença, principalmente com "as letras". Eles se contentavam em "vencer diariamente o produto mal retribuído de seu trabalho". Somado ao problema da indiferença estaria o do próprio modo de vida do operário: o esbanjamento de dinheiro, a preferência dos "prazeres noturnos nocivos ao espírito", em vez "do estudo do seu futuro". Apesar de tudo isso, tem confiança no povo para fazer progredir a nação, pois este ainda não estaria corrompido como as classes no poder.

Em A Consciência Nacional (2 de dezembro de 1877), o operário é apresentado como vítima de suas condições materiais, da exploração, injustiçado. Ele que sustentava a nação vivia mal remunerado, vexado, morando em "mansarda de estalagem imunda", convivendo com "más companhias".

Não tanto na posição de vítima, em $O$ Socialista (3 de agosto de 1878) o povo é "versátil, indiferente, apaixonado às vezes". Possui um "espírito pouco vidente", mas também, "instinto de liberdade". Qualidades instintivas são as que, em princípio, poderiam advir de um povo formado como o brasileiro: nascido de uma composição condenada - do estrangeiro depauperado moralmente, o africano selvagem da escravidão, o índio livre reduzido a escravo. Nada que favorecesse uma vida produtiva, uma existência político social, uma fraternidade social. Seria necessário esforço para reverter à situação, mas o autor só consegue ver indiferença. Baixo a essa visão pejorativa da composição do povo brasileiro, o jornal e o clube que ele representa colocam-se a tarefa de regenerá-lo contra a corrente dos poderosos que teriam criado e mantido tal degeneração. 
Na mesma linha pejorativa dos outros periódicos, Gazeta Operária (8 de janeiro de 1881) classifica o povo como inativo quedado em marasmo.

O estado do país é desanimador, mas os brasileiros quebram os remos e deixam-se levar pela corrente, cruzam os braços e na mais completa inação reduzem-se a uma sorte lastimável.

Os ânimos estão abatidos, não há grandes ambições, não há forças reconhecíveis exteriormente, dizemos, a precisa energia para que os brasileiros possam quebrar de um só golpe os grilhões de ferro que os subjugam.

Por outro lado, ao tratar da reforma eleitoral e da capacidade de reação do povo, caracteriza esse operário, identificado todo o tempo com o povo, como ser que pensa, ativo, que busca instrução, busca leituras e informação e capaz de dar respostas à lei do conselheiro Saraiva. Ao necessitar do apoio deste mesmo povo como base política vemos as representações se alterarem.

Destoando um pouco dos demais, $O$ Artista não parece conceber características intrínsecas ao povo. Parece defender a capacidade de aprendizagem e o acesso à instrução. Chega a afirmar que não se deve pensar que para ser popular um periódico deve ser frívolo. A instrução seria assim a medida de classificação dos sujeitos. Entretanto, ao se considerar como "periódico civilizador" indica que estaria lidando com um povo bárbaro.

Dessa forma os diferentes periódicos justificavam sua missão educativa junto ao público a quem se destinavam. É novamente Morel a afirmar que a imprensa de opinião fez entrar em cena o redator panfletário, homem público, visto como portador de uma missão ao mesmo tempo: política e pedagógica (MOREL, 2011, p. 35). Essa missão educativa será decomposta para análise em duas frentes. A primeira trata de como a imprensa educa, forma o público leitor, que recursos pedagógicos podemos flagrar em suas páginas. A segunda diz respeito às concepções educacionais que ela veicula.

\section{3- A imprensa no educar-se das classes trabalhadoras}

Se as associações de trabalhadores para fins econômicos ou políticos fossem escolas, os jornais seriam seus materiais didáticos. Barbosa (2010) considera, inclusive, que os jornais do período aqui estudado evocavam muito mais o formato de livros, como obras a serem lidas gradualmente. Mas esta é uma simplificação pueril, uma vez que, tanto associações como jornais surtiam um efeito educativo, alguns declaravam até mesmo ser esta sua missão, porém seus objetivos eram muito mais amplos.

Tomando a história da imprensa operária vemos, no momento aqui abordado, o princípio da organização e formação das classes trabalhadoras como agentes políticos dispostos a interferir nos 
rumos do Estado e da nação. Este se entrecruza com a formação de uma "opinião pública" que, segundo Marco Morel (2011), começa a surgir no Brasil nas duas primeiras décadas do século XIX. $\mathrm{O}$ autor se questiona sobre seu significado.

A expressão opinião pública é polissêmica - e também polêmica. (...) Ou seja, a opinião pública era um recurso para legitimar posições políticas e um instrumento simbólico que visava transformar algumas demandas setoriais numa vontade geral. (...) Desempenhou um papel de destaque na constituição dos espaços públicos e de uma nova legitimidade nas sociedades ocidentais a partir de meados do século XVIII. (...) Ou seja, a opinião pública com peso para influir nos negócios públicos, ultrapassando os limites dos julgamentos privados. Ou era vista como "rainha do mundo", fruto da elaboração dos sábios ilustrados e enciclopedistas como sinônimo de soberania da razão (...) ou então num sentido mais jacobino ou revolucionário afirmada como resultado da vontade da maioria de um povo (...) vinculada à ideia de democracia direta. (MOREL, 2011, p. 33 e 34).

Também Barbosa (2010) aponta a importância desse novo agente.

Observamos, portanto, que as letras impressas passam a ser vistas como possibilidade de difusão de ideias, usadas particularmente com sentido político. Elaborados por indivíduos letrados, esses periódicos, folhetos e panfletos amplificam os debates e polêmicas políticas. Há, portanto uma cultura política no nascedouro e começa-se a visualizar a imprensa como locus privilegiado do espaço público. (...) A partir da abolição da censura, cria-se um espaço privilegiado para a difusão das ideias e participar desse debate é não apenas se sentir incluído, mas ser ator fundamental no processo em constituição, das ideias em formação no país. Ter a força da pena, por outro lado, é tornar-se visível, reconhecido e distinguido. Muitas vezes o jornalismo é palco intermediário para se ingressar no patamar mais elevado e almejado: a política (BARBOSA, 2010, p. 51 e 52).

Diferentes categorias de trabalhadores compreenderam o poder da imprensa e, mais ou menos organizados, dispuseram-se a disputar naquela "arena", para dentro e para fora da classe em formação, os "corações e mentes" do público. Se o dito efeito educativo não é o único objetivo desses periódicos, tem extrema relevância, não só em sua dimensão instrutiva - exercício da leitura, conhecimentos gerais - mas, principalmente pelo aprendizado da política. Notícia lida, comentada, debatida. Agregava ou opunha pessoas. Levava o cotidiano de uma oficina, ou de um bairro, para toda a cidade, para toda a província e trazia o panorama nacional e internacional para dentro dos locais de trabalho, salas de associações, tavernas, cafés, quaisquer lugares onde houvesse operários leitores.

Ao tomar como fonte os jornais, entramos em contato com experiências já tratadas na consciência e na cultura (THOMPSON, 1981). Optei por pesquisar o aprendizado da política não em obras teóricas dos filósofos de esquerda do século XIX e início do XX, mas nos periódicos que, 
embora citassem e debatessem trechos de obras de Marx, Proudhon, Luis Blanc, estavam no cotidiano do trabalhador comum. Os jornais se nutriam com a matéria da experiência: os acontecimentos tratados pela consciência e pela cultura de quem os contava e de quem os escrevia. Estes conhecimentos selecionados, analisados, opinados, formatados pelo discurso, tornavam-se notícias e fatos que circulavam, eram lidos e/ou escutados, alimentando novos e velhos pensamentos, mais experiências.

A experiência não acontece sem reflexão e o efeito educativo dos jornais não acontecia ao acaso. Quando me refiro a alguns recursos pedagógicos utilizados por eles, tenho como intenção captar uma possível atividade educacional não formal, não sistemática, desenvolvida também em espaços como o cotidiano das associações de auxílio mútuo e resistência, e que encontramos, sutilmente, nos periódicos.

Não defendo que o uso do que nomeio como recursos pedagógicos, termo inexistente na documentação estudada, fosse algo previamente preparado, estratégia consciente de seus redatores. Nem eles eram jornalistas profissionais, nem o campo profissional do jornalismo encontrava-se tão desenvolvido. Barbosa (2010, p. 63-65) apresenta, brevemente, o formato dos jornais oitocentistas. Seu reduzido número de páginas, nas quais as letras se distribuíam por duas colunas, separadas, muitas vezes, por um fino traço. Entre uma e outra matéria, um pequeno fio ou vinheta mostrava a troca quase imperceptível de assunto. A limitação do espaço físico fazia com que a continuação de algumas publicações se desse no número seguinte. Ou seja, não se desenvolvera o apelo à atenção de um mercado consumidor de notícias. Mas, havia características do discurso, afinadas com os próprios códigos culturais das classes trabalhadoras que propiciavam sua apreensão pelo público leitor e ouvinte.

Os próprios jornais voltados para as classes trabalhadoras apresentavam-se conscientes e teorizavam sobre o papel educativo que cumpriam ao lado das associações e partidos operários. Em artigo enviado como colaboração por P. Caldeira ao Echo Popular (13 de março de 1890), podemos depreender que o movimento de "reformas econômicas" que deveriam ser reclamadas ao governo tinha uma dimensão pedagógica. Uma "grande reforma econômica" exigia que os trabalhadores se organizassem política e economicamente em um partido operário e em associações operárias e por meio destes se educassem e disciplinassem para aquela tarefa.

Economicamente, pois, os trabalhadores, o povo, que mourejam dia e noite sem que possam vencer as enormes dificuldades da vida principiam de conhecer que só pelos seus esforços poderão levantar-se e reclamar ordeiramente justiça para destruir os seus sofrimentos. É claro que para organizar-se uma grande reforma econômica os trabalhadores precisam organizar-se política e economicamente.

Precisam educar-se, disciplinar-se. Precisam da organização de um grande partido operário apenas composto de trabalhadores, lançando fora de si tudo 
quanto for estranho à sua classe, e precisam na parte econômica da organização de associações de ofícios, todas reunidas por uma federação.

Partido e associações eram espaços em que a classe educava-se e disciplinava-se. A julgar pelos objetivos propostos por Caldeira - uma grande reforma econômica - haveremos de convir que o alcance do sucesso desse movimento fosse uma tarefa bem mais complexa do que a obtenção de diplomas escolares. Segundo o mesmo Echo Popular (6 de março de 1890) no artigo "Associação para Luta”, estas formas de organização poderiam promover mudanças não só no sistema social, mas nas próprias vidas dos deserdados e desprotegidos. Elas seriam meios de desenvolvimento do espírito e das faculdades mentais do indivíduo.

... [a associação] estimula e promove o gosto, a vontade, o desejo ardente de saber e bem avaliar o peso enorme das injustiças e dos sacrifícios infligidos por uma sociedade que embora condenada, somos obrigados a suportá-la!

Não é só a força pelo número que o proletariado encontra na associação, é a força pela inteligência e pelo número.

A associação instrui, regenera e moraliza os costumes, obriga os seus membros a abandonar os vícios, sempre perniciosos e funestos para o proletariado, desvia-os da taverna que bestializa e corrompe e que, além disso é o instrumento mais poderoso da sua ruína o maior inimigo dos seus interesses e da sua família.

Na taverna é onde o indivíduo mais se degrada e envelhece, na associação o ignorante instrui-se, o fraco torna-se forte e o digno mais se dignifica.

Em que pese o tom otimista do discurso, o papel educativo das associações tem se mostrado historicamente verdadeiro, tanto na promoção do aprendizado da política como dos conhecimentos gerais, inclusive os saberes formais de leitura e escrita. Um caso exemplar é o do Clube Protetor dos Chapeleiros em sua luta por melhores condições de trabalho nas fábricas de chapéus da Capital Federal. A partir da realidade sensível, identificaram as causas de seus problemas e procuraram estratégias para lidar com eles. Constatando a necessidade de remover as fábricas de chapéus do centro da cidade, pois se encontravam apertadas em espaços quentes, aglomerados, sem luz e ventilação, redigem e dirigem à intendência municipal "um judicioso e longo memorial sobre o assunto" publicado no Echo Popular de 15 de março de 1890. Dessa forma os chapeleiros interferiam na política de higiene. Apesar de longa a citação, vale a pena travar o contato com a escrita bem elaborada e fundamentada dos artistas.

Imaginemos os processos movidos neste memorial como tática de luta. O estudo da realidade daqueles trabalhadores, o estudo da legislação sobre o tema, o debate entre os membros da associação e, a redação do memorial. Em sequência, a identificação de seus interlocutores e a ampliação do debate tornando-o público com seu envio à imprensa. Uma vez publicado já não se 
tem mais controle sobre ele: lido e ouvido, poderia fomentar discussões indignações, críticas e até mesmo, servir de exemplo.

Cidadãos membros da Inspetoria Geral de Higiene da Capital Federal,

A classe dos chapeleiros, representada pela diretoria do Clube Protetor dos Chapeleiros, vem recorrer à valiosa proteção dessa humanitária inspetoria de higiene, a fim de mandar executar a salutar medida já adotada pelo Código de Posturas elaborado pela Intendência Municipal dessa Capital que, infelizmente para essa classe sofredora, a sua execução foi suspensa, isto é, de mudar as fábricas de chapéus para fora do centro populoso desta cidade.

É demasiado o sofrimento dessa classe, que é obrigada, em uma estação tão calmosa, como a que atravessamos, rodeada de diversas moléstias próprias da quadra, a trabalhar ao pé de grandes maquinismos movidos a vapor, em espaço acanhadíssimo, sem nenhuma entrada para o ar e mesmo sem luz do dia, aglomerados assim os operários e em pleno contato uns com os outros, porque as atuais fábricas de chapéus, todas edificadas em ruas estreitas e em edifícios pequenos e impróprios, não tem espaço para distância dos mesmos operários; o vapor que move os maquinismos e espaça uns dos outros e, finalmente, não podendo ventilar as suas oficinas, porque estão rodeados de outros edifícios que não permitem, por exemplo, a abertura de janelas e outras medidas de pura higiene.

Nestas fábricas anti-higiênicas e verdadeiros consumidouros (sic.) de tantas vidas que, diariamente, pouco a pouco, vão perdendo a força e o vigor, extinguindo lentamente a existência pela acumulação de diversas moléstias adquiridas em um meio tão infeccioso, ilustres cidadãos, emprega-se um número muito superior a mil operários e entre estes conta-se grande número de mulheres e crianças, jovens que procuram meio de subsistência, mas que se não velardes pela saúde dessa classe, principalmente desses entes ainda na flor dos anos, em breve ver-se-ão inutilizados de ganhar o pão cotidiano como tem já acontecido até hoje a grande número de membros dessa classe. A medida da mudança das fábricas de chapéus para fora da cidade, arrabaldes ou subúrbios, e a sua execução, não será muito difícil, pois alguns dos proprietários dessas fábricas, reconhecendo a necessidade de tão humanitária medida, apreciando diariamente a luta travada entre a necessidade de ganhar o pão e os sofrimentos que suportam os seus operários nesses verdadeiros fornos crematórios, estão prontos, possuidores de maior boa vontade, a fazer a referida mudança logo que seja obrigatoriamente para todos os proprietários de fábricas de chapéus.

Muitos países da Europa, entre eles, a grande República francesa, atendendo aos motivos de higiene dos operários consignou no seu regulamento municipal a medida de serem estabelecidas fora do perímetro da cidade não só as fábricas de chapéus como também outras reputadas incômodas à saúde pública.

A imprensa desta capital federal, entre ela o simpático e popular jornal $\mathrm{O}$ País, sempre benignamente ao lado das classes sofredoras, em diversos artigos em claras e mui sensatas ponderações tem chamado a atenção da Municipalidade e da Inspetoria de Higiene para as fábricas de chapéus.

Tem por sua vez mostrado quanto em um trabalho pesadíssimo e em uma quadra epidêmica sofrem mil e tantos operários. Assim tem feito igualmente o Diário do Commercio, a Gazeta da Tarde, etc. 
Por um minucioso exame e vistoria que essa Inspetoria proceder nestas fábricas de chapéus verá com exatidão e facilidade a verdade de quanto tem dito a imprensa e nós aqui respeitosamente repetimos em reclamação.

Cidadãos - a classe dos chapeleiros, ante nós representada pelo seu Clube, espera que esta Inspetoria de Higiene composta dos mais distintos apóstolos da ciência médica, a quem está confiada a nobre missão de velar pela saúde pública desta grande Capital da República dos Estados Unidos do Brasil, amigos da humanidade sofredora, não deixareis de atender à súplica de mil e tantos operários promovendo a mudança das fábricas de chapéus para fora da cidade.

Saúde e fraternidade.

Sala de Seções do Clube Protetor dos Chapeleiros, na Capital dos Estados Unidos do Brasil, aos 14 de março de 1890.

O documento apresentado pelos chapeleiros segue os protocolos de escrita de petições e demonstra conhecimento de legislação como o Código de Posturas. Descreve sinteticamente as duras condições a que as classes operárias estavam submetidas e procura sensibilizar a junta de higiene usando-a como recurso de pressão aos donos de fábricas sem precisarem, ou tendo o cuidado, para não se oporem frontalmente aos seus patrões. Usa um discurso de contemporização de conflitos ao afirmar que "alguns donos de fábricas reconhecem a necessidade de tão humanitária medida", qual seja, retirar as fábricas do centro para arrabaldes e subúrbios. Demonstra conhecimento da causa não só no Brasil, estabelecendo comparações e tomando como exemplo a realidade a esse respeito em países da Europa, além de reforçar seus argumentos com dados da imprensa.

Reconhecendo seu papel educativo, os periódicos estudados adotavam recursos discursivos, formas de levar o público às aprendizagens desejadas. Seguimos destacando estes recursos e os traços peculiares da produção intelectual das classes operárias presentes nas fontes. Apesar da centralidade dada às matérias de opinião, em função do interesse pelas concepções educacionais e o "aprendizado da política" das classes trabalhadoras, é importante considerar o acesso à informações, o desenvolvimento da leitura e do raciocínio lógico, da cultura geral, possibilitadas por seções diversas contidas nos jornais como: divulgação sobre literatura e ciências; folhetins; e outras seções lúdicas onde se publicavam charadas e poemas, estes últimos eram mais constantes.

Além de expressão lírica, a própria poesia era um veículo de conscientização política. Diferentes periódicos publicavam poesias que tinham como temas a vida do trabalhador, a escravidão, entre outras questões sociais. Vejamos a criação do poeta anônimo, provavelmente um operário autodidata, Ceserino da Rosa, no jornal O Proletário (6 de janeiro de 1878). Desde seu título já denotava o propósito de levar o leitor à "Meditação" sobre a condição de pobreza associada ao trabalho, oposta a condição de opulência dos senhores.

\section{Meditação}


Debalde tento o futuro

nos mês sonhos descobrir

não vejo no céu escuro

nem uma estrela a luzir!

Que triste desaventurança,

Onde vais tu, esperança,

que não vens distrair?..

Ó mundo! Tuas grandezas

não passam de ilusão

Quiméricas realezas

que surgem como o vulcão!

Porém a brisa soprando

vão-se em breve dissipando

e fogem com a visão!

Guardas no seio opulentos, que bem pequeninos são

nos virtuosos intentos

porém grandes na ambição!

Que pensão dourar-te ó mundo

mas que são o foco imundo

gerando-te a podridão!

Aqui - soluça uma pobre, vergada ao peso da dor, desgraçada, porém nobre, vertendo a vida, o suor, para manter na virtude, embora sem luz e rude, a filha do seu amor!

Ali um velho curvado (que os anos passados são) pede uma esmola (coitado!) mas nem a esmola lhe dão!... Era ontem no trabalho! Hoje não tem agasalho! Caiu exausto no chão!

Por toda parte a desgraça monstro cruel a raivar! E o pobre a sorver na taça o fel que o há de matar! Sem que um só, um só instante venha um riso palpitante a sua vida enflorar! Ai! pobre! Tu és a vida um tapete multicolor enquanto a franja florida não desbota a linda cor vais o salão enfeitando mas o peso suportando do teu soberbo senhor! E depois, velho e manchado 


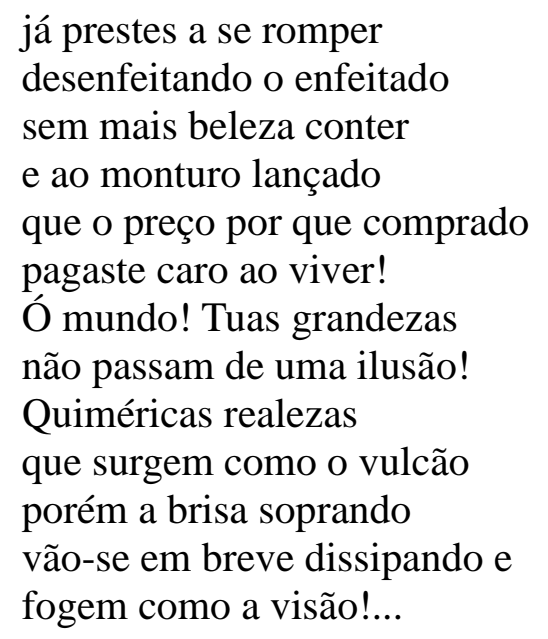

\section{Ceserino da Rosa}

Outros exemplos se repetem criados por artistas desconhecidos, em função de sua sonoridade, estavam mais próximos de uma cultura oral ainda robusta. Intercalados aos textos mais densos e extensos, falavam não só à razão, mas também à sensibilidade das classes trabalhadoras, combustível para utopias de liberdade e de um mundo novo. A Gazeta Suburbana (25 de março de 1884), em edição comemorativa da abolição da escravidão na Província do Ceará, fala em versos da "Ideia-povo". Eram muitas as ideias lançadas, passíveis de serem interpretadas e apropriadas de diversas maneiras.

A ideia-povo

Simpático avoluma-se o grande pensamento A transbordar justiça, progresso, caridade Santo desidertatum da justa humanidade, Imenso como o mar, possante como o vento!... Nos voos da razão se eleva ao firmamento Resplende de sublime divina claridade De espaço a espaço cresce o brado Liberdade! Que alegra ao d'alma nobre e exalta-lhe o talento.

Não mais senhor e escravo, mas sim um cidadão

A trabalhar sorrindo na grande comunhão

Se ver em cada homem no vasto mundo novo

Trocar gemidos e ais por hinos de louvor

Em vez do ódio de raça, leal fraterno amor

Em fim ... Abolição! Tal é a ideia-povo

O Três de Abril. Órgão dos Interesses em Geral (16 de abril de 1905), traz em uma de suas edições, o poema de Joaquim dos Anjos, em homenagem a Luiza Michel ou Louise Michel, militante anarquista francesa. Contando as histórias de personagens das lutas dos trabalhadores, a poesia também informava e contribuía para formação das culturas de classe.

Luiza Michel 
Combateu toda a vida! A santa criatura

Nunca desanimou, não trepidou sequer

Queria levar ao povo o riso da ventura

Que coragem soberba, heroica de mulher

O seu belo ideal tão sacrossanto e puro

Tinha pra ela um culto, o culto mais sagrado

Se pudesse rasgar as trevas do futuro

E alcançar a final o sonho desejado

E morreu sem o ver! Cansada de lutar

Caiu no pó da terra, inerme, enfraquecida

Morreu como Moisés e sem poder mostrar

Aos filhos de Israel a terra prometida

Combateu a torpeza, a corrupção, o crime

Tem obras de valor e coroas de glória

Povo respeitador dessa mulher sublime

No coração lhe guarda a vívida memória

Joaquim dos Anjos

O mesmo periódico traz outras marcas dessas culturas, que ele próprio fomentava. Em notas breves publicava felicitações pelo aniversário de filhos de militantes da União Operária do Engenho de Dentro: "Faz anos hoje a menina Jandira, filha de nosso companheiro, Manoel Joaquim de Queiroz, conselheiro da União Operária do Engenho de Dentro. As Nossas felicitações”. Ao fim das edições fazia uma breve apresentação da União, contendo sua data de fundação, o endereço da sede, o horário de expediente "a qualquer hora, todos os dias", e o nome de seu presidente - Pinto Machado. Por fim informava ser "a maior associação operária do Brasil, sócios em todos os locais do interior".

Quando as associações mutualistas oitocentistas, mas principalmente as associações de resistência criadas nas últimas décadas daquele século e nos primeiros anos do século XX, apontam em seus estatutos, a importância da criação de jornais como órgãos de classe, estão defendendo uma ferramenta, não só de propaganda, mas de organização interna. A publicação a cima e outras aqui citadas mostra como o jornal propiciava coesão interna, comunicação entre os próprios associados, ao mesmo tempo em que era uma ferramenta na atração de "um número ilimitado de membros".

Os assuntos culturais mobilizavam diversas habilidades que não apenas as literárias, desde a confecção de estandartes, passando pela organização de festas e eventos variados, até a própria análise política sobre a elaboração de estandartes... É o que podemos observar na pequena nota " $O$ Estandarte", publicada n' O Panificador. Órgão dedicado aos interesses da classe dos empregados em padaria (1 de janeiro de 1900).

Ei-lo que saiu das oficinas de um homem de trabalho, de um simples companheiro, de um devoto do Socialismo, que por amor ao trabalho não 
fez a mínima questão, só disse: pois não, rapazes, se faz sem ser preciso grande sacrifício. E ei-lo que cumpriu o seu dever, e nos regozijamos porque foi confeccionado por um companheiro e não por uma dessas fábricas que com o suor dos nossos companheiros se regozijam. Só nos resta a satisfação de dizermos que não demos [nada] a um fabricante agiota. José da Silva, secretário do dia e Amadeu Miranchel, que não poupou esforços para o bom êxito do estandarte, um aperto de mão. Os companheiros vos respeitam, pois sois merecedores.

Aos companheiros Martins, José da Silva, A. N. Gomes, J. S. Rocha, H. G. Hander, José de Mattos, M. Santiago, M. V. Do Valle e outros que tão poderosamente concorreram para esta festa, um abraço.

Pinho

O saber confeccionar a bandeira da organização em sua própria oficina cumpria um papel na luta de classes, por meio dele, evitava-se recorrer ao inimigo, não seria necessário comprar o estandarte em "uma dessas fábricas que com o suor de nossos companheiros se regozijam". Aquele "companheiro" teria aprendido, além da técnica da confecção, a disciplina de cumprir seu dever. A técnica da escrita cumpriria também seu papel a perpetuar tal experiência e propagá-la.

Era, entretanto, uma escrita perpassada pela oralidade, e este é um traço importante dos recursos pedagógicos que pretendemos destacar. Para além dos textos longos, havia espalhadas pelos jornais citações curtas, frases de autores reconhecidos ou não, que pretendiam sintetizar verdades sociológicas, políticas ou morais, fixando-se na memória do leitor. O Três de Abril (16 de abril de 1905) apresenta uma coleção delas, como: “A divisão do trabalho centuplica as forças de produção - Louis Blanc"; "O maior cancro da sociedade é o jogo, faz do homem de bem o maior criminoso, arrasta a honra ao lodaçal da infâmia" (sem autoria); "A melhor religião do mundo é o apoio mútuo entre os homens" (sem autoria); "Ninguém possui bastante imaginação para sentir a fome de seu próximo" - Wertheimer; entre outras.

Presente em grande parte da produção escrita, as metáforas eram recursos bastante usados nestes jornais, estimulando a capacidade de interpretação e imaginação do leitor. É o caso do "Requerimento Curioso" publicado em O Proletário (7 de outubro de 1877), na seção de variedades. Os leitores podiam se divertir com um humor inteligente, tomando contato, ainda, com um desenho de petição formal.

Requerimento curioso

Diz um coração amante nascido no lugar Tormento, termo da Vila da Aflição, freguesia dos Martírios, bispado do distrito do Desgosto e residente na cidade de Penas, que passando o suplicante pela Rua dos Mistérios, encontrou-se com a ronda de seus olhos, sendo preso à ordem de seus afetos achando-se, pois recolhido às cadeias de sua ausência, carregado com os duros e pesados grilhões do seu amor, o suplicado vem perante a sua alta beleza, requerer que o faça soltar do tirano degredo de sua ingratidão pelo 
que:

P. V. Exc. Se digne a chamá-lo a sala livre do seu peito a fim de ser interrogado e confessar o crime de amá-la eternamente.

E.R.M.

Despacho

Lastimando seriamente tal acontecimento, seja o suplicado posto em liberdade, devendo consolar-se com o presente despacho e tendo mais cautela em não se encontrar com a ronda de meus olhos para não ter a desventura de que ia sendo vítima.

No artigo "Cautela!..." de O Três de Abril (16 de abril de 1905), ao comemorar o aumento do número de associações de trabalhadores pelo interior do Brasil, a redação afirma estarem felizes "porque da árvore que plantamos já tem surgido frutos em quantidade". As metáforas criavam imagens que davam concretude ao discurso dos jornais operários. Ao lermos a transcrição de um discurso $^{82}$ proferido em meeting, relatado pelo Marmorista, quase podemos visualizar a cena dos “...privilegiados da sorte [a passear] nos seus faustosos coches, salpicando de lama a face dos operários...".

Na divulgação da doutrina de O Socialista (10 de agosto de 1878) o redator faz uso da comparação entre a estrutura social vigente de desigualdade entre ricos e pobres e o pai de família que deserda uns filhos e beneficia outros.

Imaginai uma família de irmãos, cujo pai abastado em fortuna deserdara alguns e locupletara a outros.

Mesmo que os deserdados fossem péssimos e os aquinhoados fossem ótimos, eram filhos do mesmo pai, o que é serem irmãos.

Julgareis de injustiça, julgareis de iniquidade... o que é sempre um mal, um semelhante ato.

A disparidade que aí vai na imposição da pena aos deserdados e da riqueza entregue aos aquinhoados é um fato familiar, doméstico, que pode quando ampliado dar a medida exata da injustiça, da iniquidade da doutrina antisocialista.

Saí da família e entrai no município, na comuna, no estado; observai que aqui há duas classes extremadas, uma herdeiros permanentes e outra deserdados perpétuos.

Uma a dos ricos, dos abastados, dos capitalistas, a outra a dos pobres, dos miseráveis, dos indivíduos que não tem trabalho ou que produz capital e muito menos capital para utilização do trabalho...

As histórias exemplares também tornavam mais concretas as lições a serem ensinadas e os valores a serem incutidos. N' O Panificador (1 de janeiro de 1900), o texto "Uma Lição!" conta o caso, ao que tudo indica, fictício, de José de Azevedo, um rapaz empregado num banco da capital onde ocupava um lugar modesto. "Pela sua índole um tanto vaidosa e tendo alguma instrução,

82 Mais uma mostra dessa estreita ligação entre escrita e oralidade na imprensa, especialmente na operária, é o hábito de publicar transcrições de conferências e discursos. 
ligava pouca importância àqueles que viviam do trabalho material, do trabalho rude; e se alguma vez tinha de tratar ou conversar com eles, deixava sempre transparecer nas suas palavras e nos seus modos desdenhosos uma tal sobranceria que dir-se-ia um deputado ou ministro dando ordens a seus lacaios".

Ao longo da redação é possível observar não uma, mas várias lições. A primeira, de que o grau de instrução era um fator de distinção não só econômico, pois o rapaz ocupava um cargo modesto no banco em que trabalhava, mas principalmente cultural. Por tais motivos Azevedo não era bem quisto entre as "classes menos favorecidas de instrução e que conviviam numa sociedade muito mais humilde e modesta, porém, sem dúvida, menos hipócrita e mais sincera”. A segunda lição seria de que mais instrução não era considerada naquele periódico, sinônimo de mais valor humano, uma vez que classes menos instruídas seriam menos hipócritas e mais sinceras.

No desenrolar da história, Azevedo recebe uma herança que investe em negócio próprio: uma padaria. Como dono, ele "Pagava muito mal aos seus empregados e exigia-lhes serviços fora das horas que havia determinado para o trabalho, vigiava-os constantemente, repreendia-os severamente, severamente não digo bem porque pode um homem ser severo sem ser grosseiro e sem ferir o brio e a dignidade de qualquer...”. A terceira lição, não é exatamente uma lição, mas uma caracterização do perfil do patronato: explorador, desconfiado, repressor..., aproveitando para apontar-lhes as contradições contidas no fato de, por um lado, considerarem-se superiores em sua civilidade, por outro, destratarem grosseiramente seus empregados. "Azevedo nas suas admoestações usava de uma linguagem tão baixa e ofensiva, servia-se de termos tão imorais, que não parecia um homem acostumado a pisar os salões atapetados, a tratar com pessoas educadas".

Por ironia, traço comum dos textos operários, a irmã do patrão se apaixona por um funcionário seu. Este operário é apresentado como homem digno, respeitador, sensível, vertia lágrimas por um amor impossível diante do qual mantinha sua postura de humildade. Tudo isso o fazia merecedor do amor da moça que era recíproco. A ironia maior viria ao final, quando após ser despedido e readmitido, o operário salva os negócios do patrão à beira da falência. O desfecho é um tanto inverossímil, pois o dono da padaria concede a mão de sua irmã, comemorando com um abraço em seu funcionário. Estaria assegurada a vitória da capacidade e moralidade do operário, enfim este seria reconhecido. Uma inversão foi operada: o patrão passou a ocupar o lugar de quem precisa de ajuda e o operário pode se mostrar benevolente. Mas, no fim, a ordem foi mantida, os negócios do patrão foram salvos pelo próprio operário, que, ao que parece, continuou em seu posto, embora com um reconhecimento importante: recebeu a mão da irmã do patrão em casamento. Última lição, o patrão precisava do operário e no fim das contas, pertenceram todos à mesma família, talvez à família humanidade. Esta é uma leitura possível, imaginemos outras tantas reações 
daqueles padeiros ao lerem ou escutarem esta história.

As lições exemplares poderiam vir de mais longe, como é trazido pel' O Socialista, de 3 de agosto de 1878, no artigo "Um Grande Exemplo", onde se conta o caso do operário alemão, ao que parece um militante anarquista, que seria condenado a morte por atentar contra a vida do rei Guilherme.

Condenar a morte um operário que pretende arrancar-se a si, a seus irmãos, a seus compatriotas, da miséria em que vivem.

Condenar a morte o homem das multidões, o ludibrio da pobreza, e porventura a vítima de omniosos poderes.

Condenar a morte aquele que tornou-se criminoso diante da corte por tentar ser grande libertador diante da pátria.

Condená-lo a morte é um ato criminoso se não a maior covardia de um crime.

Por que levam-no ao patíbulo?

Por que vão executá-lo?

Além do exemplo da abnegação de um operário que arriscou e provavelmente perdeu a vida por uma causa, vemos outro recurso comum utilizado pelos textos veiculados por essa imprensa, o questionário como forma de conduzir o leitor no julgamento da questão complexa. O próprio jornal adota uma posição dual, condena a tentativa de assassinato do rei pelos operários, já que a sua luta deveria ter se dado "pela imprensa, pela tribuna, pelo colóquio, pela conversa", mas também condena a pena capital, especialmente na situação limite da luta daqueles homens contra as desigualdades sociais.

Não era só pelo conteúdo veiculado, mas também pela forma da linguagem utilizada que se contestava a ordem instituída. A Revolução, de 11 de abril de 1881 noticia as condecorações ao ministro dos negócios estrangeiros sob uma forma que desafiava os padrões instituídos de moralidade e civilidade.

O sr. Pedro Luiz, digno ministro dos negócios estrangeiros, além das condecorações da Roumania e da Legião de Honra, vai ser condecorado pela Itália, pela Espanha, e cremos que até pelo Marrocos, Benguela, Afeganistão, Beluquistão, Egito, Conchinchina, Luanda e Saara. S. ex. ficará coberto de medalhas, quando elas cobrirem todo corpo, desde a ponta do nariz até os dedos dos pés, aonde mete as outras?

$\mathrm{O}$ uso do humor ácido transmitiria de forma eficaz a crítica àquela autoridade e à instituição representada por ela. A "piada" acessada por um leitor, provavelmente seria difundida, contada a tantos outros, ajudando a formar um tipo de opinião sobre o ministro em questão.

No mesmo sentido de uma escrita mais rebelde, encontramos em alguns jornais o tom de advertência ou ameaça usado contra patrões e o governo. É o caso da seção "Correio Panificador" (O Panificador. 1 de janeiro de 1900) no jornal da Sociedade Cosmopolita Protetora dos 
Empregados em Padarias. Nesta lemos: "João Maggi por causa de uns maus companheiros teve de se retirar de uma casa na Rua do Lavradio. Srs. Patrões, cuidado. Por causa de um empregado afeiçoado não se manda embora outro que está nos casos de bem servir". Ou ainda "Qual será o meio usado para se poder vender pão a 400 réis o quilo? Cuidado Farinheiros ${ }^{83}$... Assinado: O pão barato".

Outros recursos de linguagem como frases de efeito e muitos pontos de exclamação, se espalham pelos textos dos jornais, aproximando aquela escrita das formas da oralidade. Em $O$ Socialista (20 de julho de 1878) o tom indignado do editorial nos leva a imaginar as possíveis reações de homens e mulheres trabalhadoras ao lerem ou escutarem tal leitura.

Pois bem, vencendo a repugnância que nos inspiram eles, desceremos, desceremos até eles... Não importa! Se nos sujarmos, nos lavaremos na límpida e cristalina do povo (sic), que esses miseráveis turbaram para que ostentasse o aspecto das coisas repugnantes pela sordidez... E daí surgiremos de novo imaculados e mais vigorosos para esvurma-los (sic) novamente. (...) Poderão proclamar que o nosso fim é desmoralizar. Pois, é mesmo, o desmoralizar os imorais. Por isso nos transformaremos muitas vezes em poste em que esses serão atados para serem vergastados.

O mesmo periódico nos dá ainda outros exemplos da ligação entre sua redação e o mundo da linguagem oral no momento em que mantém uma seção onde publica "boatos" e mantém a prática, como em outros periódicos do seu gênero, de transcrever conferências proferidas por diversos sujeitos. No número de 20 de julho de 1878 anuncia que "Brevemente aparecerá um discurso do ilustrado Sr. Dr. Lopes Trovão...”. O Marmorista (1 de dezembro de 1906), por sua vez, publica resumo de discurso proferido por Carlos de Araújo, o Cavaco, secretário do republicano Petit Journal, acompanhado de perto pelo operário Francisco Xavier da Costa, provavelmente quem relatou o discurso para o jornal dos marmoristas, num momento em que "A Praça da Alfândega" regurgitava de povo às 4:30 horas da tarde".

Barbosa (2010) mostra a simbiose entre oral e escrito pela qual surge a imprensa no Brasil, no início do século XIX. Suas fontes de informação seriam, segundo a autora, além das notícias de jornais estrangeiros compiladas, o "ouvir dizer", "por se falar", "por chegar aos nossos ouvidos", “...expressões que mostram a contaminação do mundo oral nas letras impressas. (...) Os boatos se transformam em fonte privilegiada de informação. Mas, é preciso descobrir o que de fato está acontecendo. (...) E quando ganham nova materialidade, é como se tivesse sido desfeita a imprecisão das informações. (BARBOSA, 2010, p. 23 e 28).

A seção "Telefonia Padeiral” de O Panificador (1 de janeiro de 1900), é mais um indicativo da simbiose citada a cima. Temos ali a reprodução de sons do telefone e de diálogos ao telefone.

83 Grifos meus. 
Cada pequena "esquete" começa com o toque do aparelho: "Trim-lim-lim", ao que se responde: “Alows. Quem fala?”. Cada chamada é a deixa para uma sátira à sociedade carioca, ou para uma propaganda do próprio jornal dos padeiros. Seguem citadas algumas, para compartilhar a diversão.

Trim-lim-lim

- Alows. Quem fala?

- $\quad$ Padaria Rua de São Pedro.

- Que quer?

- Um padeiro que ature o patrão de manhã.

- Ao Paciência.

Trim-lim-lim.

- Alows. Quem fala?

- Padaria Fábrica das Chitas.

- Que deseja?

- O Jornal "O Panificador".

- Subscreva na lista voluntária.

Trim-lim-lim.

- Alows. Quem fala?

- $\quad$ Padaria Rua D. Ana Nery

- Que deseja?

- Tratar bem os empregados.

- $\quad$ Não faça questão de dar mais 500 réis ao cozinheiro.

A ironia era um traço importante da produção intelectual que compunha os jornais de trabalhadores. No artigo "Acautelem-se”, O Proletário (17 de novembro de 1877) discute o caso, publicado n' $O$ Globo, "folha neutra na luta de partidos", de um operário punido por tentar impedir que "certos vizinhos abusassem infamemente de suas irmãs menores". Ele foi acusado de capoeira e enviado para assentar praça nos corpos da marinha. Sentença que, segundo o redator, representava o mito da lei no Brasil. "Ela tudo pode e tudo empreende contra o pobre. Para os ricos, a lei é cega e sem valor". A forma encontrada de reforçar a conclusão ao fim do texto é, exatamente, a apresentação das contradições em que estavam inseridas as autoridades mantenedoras da lei, a quem ironiza. A ironia aparece assim como uma forma mais sutil de desmoralizar outrem, sem atentar contra os ideais de civilidade em voga à época.

(...) atrás do devasso e impudico que conta com influência veremos o espectro da polícia com seu braço armado de milhares de meios ilegais e vexatórios e entre eles - a polícia que vive com capoeiras e capangas, tem o poder de prender qualquer cidadão por capoeira e vagabundo!!

E ai dele hoje que há uma lei que regula o sistema de recrutamento o pobre diabo pode ser remetido e é para a marinha e sujeito ao calabrote!!

Boa polícia!

Poderoso empenho!

Melhor chefe de polícia ainda! 
A desconstrução da autoridade da polícia suscita, por fim, a proposição, outra característica dos jornais aqui estudados. "Acautelem-se os chefes de família é necessário uma polícia do povo com moralidade que policie a polícia do governo desde o chefe até o último beleguim”. A força pública era, sem dúvida, um dos alvos prediletos da ironia dos periódicos operários. É o que percebemos nas pequenas notas críticas de $O$ Socialista (20 de julho de 1878) que não poupam também o Correio da Corte. "Esta polícia é de uma atividade extraordinária, porém, para quem possui amigos... Boas! Assinado: Onde está o Valente?”. “As cartas que são enviadas do interior, por que não entregam logo depois da chegada do trem? Assinado: O inimigo da preguiça”.

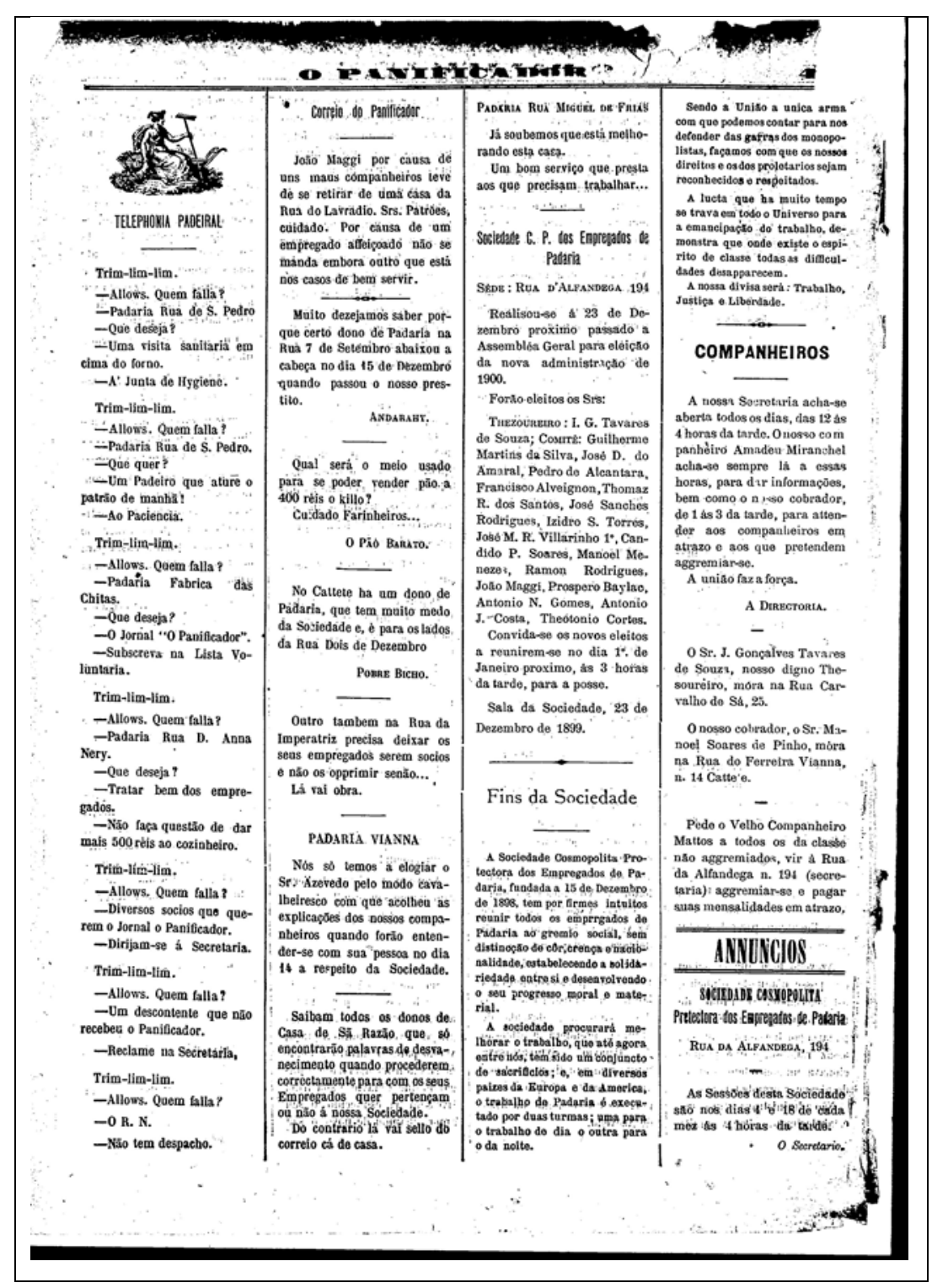

Figura 3- A irônica seção “Telephonia Padeiral”, em O Panificador, de 1 de janeiro de 1900.

O tom propositivo citado a cima, quanto à criação de uma "polícia do povo", estava presente 
no artigo seguinte do mesmo jornal. Em "O Capital” o modo de vida dos operários que "preferiam os prazeres noturnos nocivos ao corpo e ao espírito (...) ao estudo de seu futuro", é criticado. A situação requeria, do próprio periódico, todo um discurso destinado a educar os costumes de seu público, o que faz solicitando do operário "um pequeno cálculo". Sugere que as "despesas inúteis" fossem empregadas na fundação de um banco, e segue demonstrando alguns cálculos não tão pequenos... Solicitando, ao final, que os operários mais habilitados desenvolvessem e estudassem a proposta.

Criando-se uma associação com um capital de 100:000\$000, dividido em 10.000 ações de $10 \$ 000$ e uma vez realizado o capital, ser empregado em apólices da dívida pública, que obtivesse a renda de $6 \%$ ao ano, daria um resultado de 60:000\$000, que podiam ser empregados em empréstimos com um juro regular, fazendo-se depois o dividendo das ações e no fim de 10 anos teríamos o seguinte resultado:

Juros de capital: 600:000\$000

Juros de empréstimo 5\% ao mês: 720:000\$000

Total sem o capital: 1.320:000\$000

Que repartidos entre as ações de $10 \$$ cada uma tocaria $32 \$$ por ação.

Entendemos que não seria difícil capitalizar-se no fim de cada ano $100 \$ 000$ e no final de 10 anos um capital de 1:000\$000 com um lucro de 2:200\$000 e assim progressivamente.

A primeira vista nos parecerá difícil a acumulação de $100 \$ 000$ por ano, mas o gosto pela associação, a ideia de um progresso traria um bom resultado e facilitaria a amortização.

Semelhante empresa depende tão somente de uma reunião de operários e da escolha de uma comissão que desenvolvendo bem a ideia confeccione uns estatutos capazes de prever todas as lacunas.

Só assim acabar-se-ia com essa súcia de abutres que especulando com as necessidades do operário rebatem férias com até 15 e $20 \%$ ao mês, pois dado que fosse a realização da ideia apresentada o operário recorreria a seu banco.

Não queremos ser os incorporadores da companhia, porém, expondo a ideia, desejamos que operários mais habilitados do que nós e desenvolvam e estudem.

Além do constante estímulo ao estudo e à associação, o estímulo à crítica era um traço da ação educacional destes periódicos. O Proletário se apresentava como "órgão dedicado aos interesses do povo, crítico e literário", disposto a "discutir princípios" e "apontar erros e abusos", levando o leitor à reflexão e, possivelmente, à formulação de suas próprias opiniões sobre as polêmicas veiculadas. Nesse sentido a construção do conhecimento passava quase sempre por um exercício analítico, fosse da experiência vivida ou de textos veiculados pela grande imprensa e por outros órgão voltados para as classes trabalhadoras. Mesmo quando um periódico transcrevia matéria de outro, esta nunca ia sem cometários, ainda que breves, sem manifestar suas opiniões. É o 
que acompanhamos nas discussões sobre as "Casas para Operários" extraídas do Jornal do Brasil. O redator de $O$ Três de Abril considerou que o tema tinha sido habilmente discutido, mas parecia “não sair do terreno da teoria”. A crítica do Três de Abril (16 de abril de 1905) ao Jornal do Brasil deixa transparecer, novamente, o traço propositivo das formulações operárias, que preconizam a associação constante entre teoria e prática.

Ninguém - operário ou proletário - espera que o capital construa habitações para o trabalho o capital quer avolumar e crescer a custa do braço do homem trabalhador, o que pensa é só em explorar cada vez mais os homens que tudo produzem, mas dar-lhes mais conforto, mais ar, mais luz e mais pão, isso nunca. $\mathrm{O}$ capital quer o operário escravo, não pode ver com bons olhos o operário consciente e livre, teme-o e faz-lhe guerra quando o vê a caminho de sua emancipação.

Esperar pois que o capital - governo, ou capital indústria - faça alguma coisa a favor dos operários é uma utopia.

Não esperamos por tal. Agimos nós, fundemos, ou levemos avante a ideia de fundar um congresso operário onde se reúnam todas as associações operárias da capital, e ali devemos esposar a causa de maior necessidade para o operário, que tanto se faz sentir a sua falta.

Ao "Jornal do Brasil" nossos aplausos pelo abrigo dado a esse momentâneo assunto.

Operários!... A caminho da prática!...

A formulação citada não é, pois, contrário a teoria. Ela utiliza a ferramenta da teoria, nos termos de uma sociologia com traços marxistas, já ventilada por aqui, mas ao fim, convoca a classe à ação. O saber se completaria no fazer.

Sem o abandono da teoria, a experiência é valorizada nas páginas dos jornais estudados e por isso mesmo consideravam que deveria ser compartilhada. Segundo a redação de $O$ Três de Abril 16 de abril de 1905), "nos compete avisar o que de ciência própria conhecemos". Estes conhecimentos não eram encarados pelos operários como verdades válidas apenas em seus círculos, mas que deveriam atingir a sociedade que os desqualificava e forçá-la a reconhecer seu valor. "Para providenciar sobre a reforma em nosso bem, dessa sociedade que procura desconhecer o nosso valor, só o número. Para a força, força, mas a força das nossas convicções, a força dos nossos méritos e dos nossos conhecimentos".

Os saberes adquiridos no fazer cotidiano eram matéria-prima da "prática pedagógica" desenvolvida pela imprensa voltada aos trabalhadores. O mesmo Três de Abril (3 de setembro de 1905) traz no artigo "Lar Operário", os ensinamentos sobre administração do lar e bem viver, dados por uma mãe e esposa operária. Esses ensinamentos tomavam forma de conselhos dados por uma mulher que cumpria seu papel de forma exemplar. A mulher exemplar era resumida à boa mãe e esposa.

Tem a palavra para aconselhá-los, a excelente companheira de um operário 
nosso consócio e digna de ser o modelo da mãe e das esposas.

"Nossos vizinhos se admiram do nosso bem estar, no entanto eles podem agir tal como nós.

Não gastamos nem um vintém em álcool, somos inimigos do enorme cancro social - o jogo - só compramos o necessário e somente o que podemos pagar. Evitamos sempre dever. Acautelamos o que é nosso porque representa nosso trabalho. Eu e meu marido temos um só modo de pensar antes de tudo somos muito amigos.

Trabalhamos os dois - um auxilia o outro na medida de suas forças. Se isto é felicidade, aí tens o segredo, só não é feliz quem não quer.

Sim, a felicidade do lar, só a mulher se poderá encarregar, e só a ela compete fazê-lo alegre não se tornando exigente quando não o possa ser.

Felicidade com tão pouco se faz; carinho e amor mútuo entre os dois indivíduos que se ligaram, ei-la.

Albina e Gil

Diretora da União Operária

Ocupando prioritariamente os bastidores do lar, as mulheres seriam as conselheiras práticas. As lideranças que desenvolviam a escrita e produziam teoria, consideradas "conselheiras mentais" eram, em geral, figuras masculinas. Entretanto, o caso de Elisa Schide, militante homenageada pelo Três de Abril, chama atenção por se tratar de uma mulher que não vem a público como mãe e esposa, portadora de um saber prático, mas considerada como "um dos cérebros privilegiados, de mais talentos e conhecimentos científicos". Mas mesmo ela, uma "intelectual orgânica", a frente da formação de um partido operário, teria realizado seu grande aprendizado sobre a vida operária no terreno da experiência.

Filha dum distinto engenheiro alemão, que brasileiro de coração, foi por muitos anos funcionário da Estrada de Ferro Central do Brasil, aprendeu com seu pai, no verdadeiro campo da miséria e do sofrimento, em meio dos trabalhadores, a defender os pobres e humildes sempre sedentos de justiça.

(...) E foi o fato dela conhecer bem que o progresso ferro carril foi conquistado a custa de centenas de vidas de batalhadores pelo pão pro lar que essa genial senhora se tornou o eco dos que sofrem, colocando sua esclarecida inteligência e talento superior ao serviço da nossa causa que representa a batalha do bem futuro. (...) Em homenagem ao nome de tão excelente amiga do operariado, as escolas que sustenta a União, tem o nome de Escolas Operárias Elisa Scheid (O Três de Abril. 10 de setembro de 1905).

M. D. De Almeida, n' O Marmorista (1 de janeiro de 1907) estende o debate sobre a relação teoria e prática à crítica que faz ao próprio Movimento Operário, principalmente às suas lideranças. Se por um lado, vemos a maior parte dos redatores das folhas operárias caracterizarem "o povo", ou, "os operários" em seu conjunto, como apáticos e ignorantes, vemos nas palavras de Almeida que "Os operários sabidos, os orientadores daqui, são aqueles que, ou demasiadamente míopes, não 
veem como sofre o trabalhador, ou não lhe reconhecem o direito à vida senão como uma concessão dos açambarcadores do capital”. Segundo ele, faltava às lideranças operárias o estudo da realidade e da história do movimento. Seria um estudo de doutrinas e da prática, já que ele próprio teria aprendido com ela. "Aos poucos anos que me envolvo no movimento operário, me ensinaram pela prática, que a ação deve ser de rebeldia e só me levaria a fazer o contrário por falta de inteligência para compreender que nada se obtém dentro das normas até hoje mantidas...".

A crítica do marmorista se torna severa.

Ora, eu não sou um espírito excepcional senão medíocre e creio que todos os indivíduos que escrevem e orientam, sabem melhor do que eu como devem proceder e é claro, se não o fazem, é porque só querem saber de si e não se sacrificar por este ou aquele, não querendo aturar a burguesia absorvedora procuram por qualquer meio viver independentes, explorando opiniões, preparando terrenos para serem jornalistas e propagandistas, pagos por operários que não saindo do círculo de ferro onde os fecharam se deixam levar por eles com suas doutrinas que fazem sucesso entre grande massa de analfabetos que são os trabalhadores; e merecendo o elogio da burguesia, representada pela grande imprensa que acata a sua ação por não atacar diretamente o capitalismo.

Representando-se retoricamente como "um espírito medíocre", com intuito de destacar a imagem de brilhantismo feita dos "indivíduos que escrevem e orientam", considera que muitas lideranças operárias, ao separarem teoria e experiência, não viviam o que pregavam em seus escritos. Dessa forma estariam compactuando com patrões e apenas aplainando o terreno para viverem do jornalismo e propagandismo pago pelos operários, desenvolvendo doutrinas exteriores à "massa de analfabetos que são os trabalhadores", sem atacar diretamente o capitalismo.

Diante dos motivos expostos, M. D. Almeida finaliza seu artigo propondo aos leitores que assumissem papel de protagonistas em sua reflexão e em sua ação, uma vez que, só os próprios trabalhadores possuiriam o saber, vedado até mesmo aos seus advogados, sobre as próprias necessidades. Estas necessidades, bem como os movimentos anteriores, e as palavras de todos aqueles que não fossem seus companheiros de trabalho, deveriam ser matéria para estudo criterioso, do qual se extrairia a conclusão sobre o caminho a seguir, rumo a emancipação, que entende, citando Karl Marx, ser "obra dos mesmos trabalhadores".

Como se faz disto quando consideramo-nos incapazes de parlamentar com os patrões e legamos os nossos direitos a advogados que nunca poderão saber exatamente a intensidade das nossas necessidades, e vemos os nossos companheiros de trabalho arredios da sindicalização por falta de estudo e propaganda? É que no Rio de Janeiro nada disso se cogita, a não ser quando nos achamos em dificuldades, uma vez dela saídos, embora mal, já aquilo nos passa como um sonho.

Lembrai-vos companheiros o que disse Karl Marx: A emancipação dos trabalhadores será obra dos mesmos trabalhadores. 
Procurai nos movimentos anteriores e nas vossas necessidades o verdadeiro guia. Dos vossos orientadores, não sendo os vossos próprios companheiros de trabalho não devem merecer a sua palavra se não um prolongado estudo criterioso que de acordo com a vossa situação, tirareis a conclusão sobre o caminho a seguir, isto sendo eles advogados, ou trabalhadores conscientes, sendo que os vossos advogados só podem desempenhar o papel de empregados e nada mais (O Marmorista. 1 de janeiro de 1907).

A prática e a experiência eram consideradas mestras, mas as próprias ideologias revolucionárias, como o anarquismo, eram representadas nestes periódicos como fruto da ciência, do estudo e do conhecimento. É o que afirma Felix Pereira em Força Nova (24 de julho de 1907).

Mas, graças à ciência moderna chegamos à conclusão que para os estômagos cheios não há mais que o Deus-Ouro; que o Estado só serve para que vivam dele uns quantos degenerados, que cometem toda sorte de infâmias para com o povo, sobrecarregando-o de impostos para sustentar uma massa inconsciente, armada de fuzis prontos para nos fuzilar caso não queremos submeter-nos a seus caprichos.

Os que mais sofrem com seus impostos são unicamente as classes trabalhadoras.

Entretanto, nós, os anarquistas, queremos que cessem todas as infâmias, que não existam irrisórias preocupações, que desapareça a exploração do homem pelo homem, desaparecendo por completo tudo que perpetua os deserdados da sociedade, elevando-os a altura de escravos modernos sujeitos a seus senhores.

Tais conhecimentos deveriam ser apresentados ao público leitor de maneira didática. É assim que Fábio Luz explica, no mesmo periódico, o mecanismo e significado da acumulação de capital de forma lógica e em poucas linhas.

Ideólogo

Para reunir "capital" tem de explorar o trabalho alheio. Figura um operário que monta uma oficina, se o trabalho lhe vier em abundância ele tomará aprendizes, formará mais tarde oficiais e poderá chegar a ser chefe de uma fábrica. Se, pelo contrário, aceitar só o trabalho de que possa dar conta com seu único esforço, apenas ganhará o suficiente para que possa não morrer de fome com os seus. Todo capital acumulado quando não está manchado de sangue está umedecido de lágrimas e suor.

Fábio Luz (Força Nova. 24 de julho de 1904)

O Socialista (20 de julho de 1878) também se preocupa com o didatismo na abordagem da “doutrina socialista". A sua explicação do que ela quer e do que ela nega é feita sob a forma de perguntas e respostas, recurso que o jornal usa frequentemente.

O que quer ela? O que pede o socialismo?

Verdade nas teorias sociais, verdade nas práticas sociais, verdade nas consequências sociais.

O que nega ela? O que é que a doutrina socialista repele?

A mentira, o absurdo. 
O que quer ela? O que pede o socialismo?

Verdade nas teorias sociais, verdade nas práticas sociais, verdade nas consequências sociais.

O que nega ela? O que é que a doutrina socialista repele?

A mentira, o absurdo.

O direito de conquista, o direito de herança.

Quem pode negar que aí existe muito fundo bom?

Ninguém.

A sede de conquista é um princípio que de absurdo que é, deriva consequências absurdas.

Ponde Ciro de frente de Baltazar, tereis a covardia e o assassinato... Mas chamareis conquista.

Colocai Alexandre diante de Tebas e vereis ruínas sucedendo a cidade.

Tereis a morte sucedendo a vida; o incêndio sucedendo a habitação; da ruína sucedendo a edificação.

Situais Dario, Xerxes diante de Esparta e de Atenas extasiai-vos aos gritos tumultuários, ao sangue, aos ferros em Maraton, Platéa, Termópilas e Salamina.

Procurai Roma e os soldados; a conquista e o roubo, a devassidão e o furto.

Evocai os Césares, evocai os Antoninos, desenterrai Macrino (...) e dizei que foram bons, que tiveram o exercício de um direito, defendei esse parto monstruoso da cabeça e do braço e... tereis defendido a doutrina antisocialista; isto é, tereis sustentado o direito de conquista junto ao direito de ruínas; tereis absolvido a culpa o direito de hereditariedade dinástica e o direito de herança doméstica.

É isso um bem? É isso aceitável? Mil vezes que não.

(...)

É preciso dizer aos reis: Nascestes dos conquistadores, sois absurdos sociais.

É preciso dizer aos que herdam: individais a nossa pátria perdulais a fortuna que não adquiriste porque não trabalhaste, sois indignos de possuí-la, entregai-a ao estado... dai à sociedade por meio do tesouro público da comuna.

Sede socialistas.

Além da repetição de sentenças e do uso do imperativo para reforçar a argumentação e afirmar a doutrina, outro recurso bastante usado é a história como exemplo e como mestra explicadora, nesse caso o exemplo do abuso das conquistas e da origem do direito de herança. No Editorial de 27 de junho de 1878 o autor sugere: "Recordai a história, a boa mestra". E, ainda usando este mesmo argumento, no artigo intitulado Princípios e Consequências dá conta do percurso da humanidade até o estágio atual de desenvolvimento, momento em que a propriedade privada teria surgido como consequência brutal e violenta da luta do homem contra o homem, precedida por um estágio anterior da luta do homem contra as feras pela sobrevivência. Neste mesmo artigo reafirma o sustentáculo de suas verdades - "Se não, indagai da história, a mestra de todos os povos, companheira imperecível de todas as ações. Indagai impertinente e ela vos responderá". 
Para algumas correntes do movimento de trabalhadores, os jornais eram instrumentos de ação revolucionária, enquanto a revolução era, ela mesma, um processo pedagógico em que se "preparavam homens". "A ferocidade com que a infame burguesia sustenta a sua tirania sobre os homens do trabalho, terá a sua recompensa no mais pequeno movimento de solidariedade que se agite entre nós, mas para chegarmos ao termino desse movimento precisamos preparar homens ${ }^{84}$ conscientes dos seus atos para quando se der o grito da REVOLUÇÃO todos sigam o mesmo caminho enfrentando a luta em todos os terrenos".

Não só o processo revolucionário seria pedagógico, mas também o processo decisório democrático, adotado em algumas associações operárias ${ }^{85}$, como divulga $O$ Marmorista. Órgão de Propaganda dos Operários Marmoristas, que segundo o articulista A. C. Christino era lido pelos seus companheiros "com avidez". Ao convocar a categoria a participar das atividades da organização de classe, afirma que "ali não prevalece a vontade deste ou daquele, todas as ideias são discutidas e formadas em leis, que nós podemos e devemos respeitar, como também nos é dado discutir e confeccionar". Trabalhadores que leem, que têm ideias e que escrevem essas ideias. A criação de uma legislação naqueles moldes era trabalhoso e complexo. Podemos imaginar que envolvesse uma análise da sociedade em que estavam inseridos e da condição de sua categoria. Envolvia o cálculo das diversas opiniões e interesses internos, o conhecimento das formalidades da linguagem jurídica e por fim a formalização escrita. É importante salientar que, de fato, segundo registra o próprio jornal, havia toda quarta-feira, no endereço da Praça Tiradentes, número 71, a reunião do conselho administrativo do Centro dos Marmoristas, composto por representantes das oficinas, a quem era solicitado assistir "ao maior número de reuniões que lhes seja possível”.

Dessa forma, os trabalhadores do mármore se educavam pela sua própria experiência em elaborar uma legislação social, mas também pela experiência de outras categorias relatada e analisada em seu periódico. Na seção "Movimento Operário", O Marmorista (1 de dezembro de 1906) noticia a greve dos sapateiros considerada "um belo ensinamento".

Longo tempo se mantiveram em greve estes companheiros. Quiseram implantar um regulamento e uma tabela geral, o que muito lhes custou e que, aliás, não parece ter dado o resultado satisfatório, mas foi um belo ensinamento para todos os operários. Provou que não só se torna necessário a organização onde todos sejam associados, como ainda que sejam sempre tratadas com cuidados as resoluções a tomar procurando sempre uma tática para se obter resultados.

O processo da greve dos sapateiros, mesmo malograda, e talvez por isso mesmo, serviu de

84 Grifo meu.

85 Sobre uma pedagogia dos movimentos sociais ver Arroyo (2003). 
aprendizagem não só para aquela categoria ${ }^{86}$, mas para o movimento operário. De onde podemos extrair que o saber de experiência não é apenas aquele que o indivíduo vivencia pessoalmente, mas aquele gerado na realidade histórica de sujeitos que podem ser individuais ou coletivos. Vemos que aquela experiência e os ensinamentos gerados a partir dela sobre a necessidade de organização e de uma tática para obter resultados, circulava de forma oral (o que não precisamos de "provas" documentais para afirmar) e de forma escrita, disponível para ser apropriada pelos trabalhadores imediata e posteriormente.

Situações de outras categorias como foguistas, carroceiros, carpinteiros, pedreiros e empregados em bondes também eram tomadas como exemplos, ou material para análise, pelo Marmorista. Mas, sua própria greve resultaria em "fecundos ensinamentos". O periódico relata o embate que se deu nas "oficinas de Friederichos".

De lá muito vinham se sentindo lesados aqueles operários, e dir-se-ia que com as privações que viram-se obrigados a sujeitar-se, adquiriram também energia para a luta quando julgassem oportuno o momento de agir.

Este momento chegou e a greve manifestou-se com a espontaneidade que caracteriza entre operários que não esperam ordens nem obedece a outros gênios para as suas ações, que não a própria consciência do seu valor e a firme convicção dos direitos que lhes pertencem.

Os marmoristas demonstraram a força que somos quando solidários para a defesa dos nossos interesses imediatos e fizeram compreender aos patrões, que nós não somos simplesmente as máquinas passivas das quais apenas se ouve o surdo rumor das engrenagens e que com uma regularidade matemática lhes dão um tanto por cento sobre o capital; sobre homens, pensamos e sabemos agir (O Marmorista. 1 de dezembro de 1906).

Os ensinamentos da ação relatada não foram apenas para a classe, que aprendeu sobre o poder da união. Os marmoristas também "fizeram compreender os patrões" que não eram máquinas. Mas tais aprendizados podiam ser dolorosos. A mesma edição do periódico, conta sobre as consequências da greve, em que alguns marmoristas foram demitidos e mandados para fora da Capital Federal, tendo de ir buscar trabalho em outra parte. Exemplar foi o castigo e foi também a atitude dos trabalhadores. Muitos outros estavam presentes para ver a partida dos marmoristas.

Grande número de trabalhadores de todas as classes compareceu ao trapiche a fim de levar suas despedidas e demonstrar solidariedade aos marmoristas. Diversas associações operárias se fizeram representar tendo feito uso da palavra alguns operários, despedindo-se dos companheiros que partiam e em enérgicas palavras concitando os trabalhadores em geral a continuarem a luta encetada pelos marmoristas em prol das 7 horas.

Uma comissão composta dos operários: Arquimedes Fortini, Henrique A.

86 Cabe lembrar, como no capítulo anterior, que não se fazia uso do termo "categoria" à época, o seu uso pontual neste texto tem a ver com a necessidade de não confundir classe (usada à época da forma que entendemos categoria, hoje) e classe social, em sentido mais amplo. 
Martins e Armando A. Martins, apresentou despedidas e ofereceu um ramalhete em nome dos operários das Oficinas do Jornal do Commercio (O Marmorista. 1 de dezembro de 1906).

Dois casos podem ser considerados emblemáticos dos processos de auto formação intelectual das classes trabalhadoras, parte do educar-se a que nos referimos. A Revista da Associação dos Guarda-livros que expõe de forma bastante detalhada a prática daquela organização, bem como $O$ Tipógrafo, que apresenta o desenrolar da greve de sua categoria e o próprio desenvolvimento do periódico. Serão estes os dois exemplos tratados a seguir.

Os guarda-livros, empregados no comércio, portadores de uma formação técnica específica que poderíamos localizar, hoje, entre o ofício de contador e administrador, reuniam-se em associação com o principal intuito de estudarem, nas horas que lhes sobravam do trabalho, as questões relacionadas ao mundo do comércio e da produção, adotando para isso metodologia própria.

No Editorial de 31 de janeiro de 1874 da Revista dos Guarda-livros, informa que "fazem parte do nosso programa social, as discussões de teses relativas à corporação que pertencemos, dando elas ensejo para nossos consócios mostrarem quanto é proveitoso e útil o emprego das curtas horas de suas árduas e nem sempre apreciadas obrigações que ficam vagas". Porém, deixa claro que as discussões de teses não versariam sobre questões políticas "e se o comércio não estivesse filiado e dependente dessas circunstâncias que o tem muito prejudicado, sem dúvida não tocaríamos em tão ingratos assuntos".

As seções da associação começavam por volta de oito horas da noite, quando a ata da seção antecedente era lida e aprovada dando início às discussões de teses. As teses partiam de perguntas propostas à mesa coordenadora, em seguida o presidente da associação nomeava sócios para a tarefa de estudarem e desenvolverem respostas que seriam avaliadas por pareceristas. Estes resultados eram também levados à apreciação dos sócios em reunião, onde eram aprovados ou reprovados em votação.

Além do processo de construção e debate das teses e de sua publicação na revista, havia outros recursos utilizados pelo periódico dos guarda-livros na educação da classe, como a publicação de traduções de obras técnicas feitas pelos próprios guarda-livros. Atividade intelectual desenvolvida no curto tempo que restava de seus afazeres.

Aproveitando o diminuto tempo que dos nossos afazeres fica disponível, empreendemos esse trabalho, se nos guiássemos pelos ditames da consciência era certo o desânimo, porquanto ela é a primeira a evidenciarnos a falta de habilitações para esta tarefa.

O desejo, porém, de estudo e o de preencher a importante primeira parte, tão olvidada, dos nossos trabalhos semanais e a convicção do real 
aproveitamento para todos os senhores sócios desta útil Associação: encorajam-no na presente conjuntura.

Não só as habilitações como a falta de tempo, impedem-nos apresentar tradução correta, o que não afeta a essência das doutrinas de H. Macleod, expostas pelo autor do livro, Henri Richelot, concernentes à importante ciência denominada - Economia Política (Revista da Associação dos Guarda Livros. 31 de janeiro de 1874).

Além da publicação de teses e traduções de obras, disponibilizavam-se outros meios informativos e instrutivos para o ofício como tabelas de taxas de câmbio, volume de exportação e preço do café, açúcar, algodão, charque, farinha de mandioca, feijão, milho, água ardente. Junta-se o movimento das apólices gerais e das ações de companhias.

No editorial de 28 de fevereiro de 1874, a Revista da Associação dos Guarda-livros expunha sua missão educativa ${ }^{87}$ e convocava os sócios a contribuírem com seus conhecimentos e publicarem seus escritos.

Cremos que não se nos levará em conta de ostentação o empenho que nutrimos de procurar moralizar a classe a que pertencemos por meio de um centro que lhe dê importância e força moral e de fazer com que a associação só por si, possa imprimir nos Guarda-Livros, seus associados, o merecimento que uns regateiam, outros lhes contestam e muito poucos reconhecem. (...) Venham, pois, todos aqueles que se prezam de honrar a nossa classe, e que dispõe de um maior ou menor cabedal de conhecimentos, auxiliar-nos com o seu apoio, com o contingente de suas luzes, na gloriosa cruzada em que nos empenhamos, venham aqueles que se ufanam de possuir o bem entendido espírito de associação ajudar-nos na obra do nosso próprio engrandecimento moral, aproximem-se do nosso grêmio todas aquelas aptidões que tanto se distinguem no comércio como Guarda-Livros práticos e de mérito real, e venham ilustrar as colunas de nossa Revista com seus escritos ...

Quando falamos em educação de trabalhadores via imprensa ou associações, é importante ter em mente que não se trata necessariamente de uma educação de nível primário ou de primeiras letras, mais comumente designado à época. Não é possível fazer tal equiparação com os níveis de escolarização formal quando se trata do movimento mais ou menos difuso do "educar-se" pela experiência, no cotidiano dessas instituições. Pelo exemplo dos guarda-livros podemos ver que há

87 Esta sociedade que se descrevia o tempo todo sob o signo da atividade intelectual, não deixava de se identificar com o universo de trabalhadores, mas seriam trabalhadores intelectuais. Viviam uma situação ambígua que transparece no artigo "O Comerciante e o Guarda-livros" de 30 de abril de 1875, entre sua proximidade com o comerciante, o patrão, e a falta de reconhecimento daquele a que se ressentem a todo momento. Esta associação reafirma incessantemente a sua missão educativa, como no artigo Sociabilidade no mesmo número: “A nossa associação tem apenas o orgulho de dizer que faz nascer a sua origem na classe daqueles que se nobilitam pelo trabalho acurado e honesto. Ela vem, portanto, daqueles que envolvidos de contínuo em um labirinto infernal de algarismos, preocupados pelos cálculos aritméticos, aproveitam as escassas horas que lhes sobram de suas laboriosas ocupações para, congregados em associação, aprenderem com a convivência íntima de mestres e ilustrarem-se pelo estudo". 
categorias de trabalhadores que desenvolvem e formalizam saberes que estão muito além das habilidades puras e simples que a leitura, escrita e operações matemáticas básicas poderiam propiciar.

Mas a associação não abandonava o formato escolar como alternativa instrutiva e educativa, ao que vemos na seção de notícias da revista a inauguração de seu curso noturno de línguas. As aulas de inglês começavam naquela data, no horário de sete da noite ministradas pelo professor Sr. Alexandre D'Enea, o mesmo que ministrava as aulas de língua francesa. "Estão, pois, funcionando as duas aulas, esta às segundas e quintas feiras e a de inglês às quartas e sábados. Os Srs. Sócios que desejarem possuir ou aperfeiçoar-se no manejo de tão úteis conhecimentos devem apressar-se em aproveitar os serviços que a Associação quer prestar-lhes e que acreditamos, poderá mais tarde ampliar, fazendo-os extensivos ao público".

Surgindo em meio à greve dos trabalhadores das três maiores folhas diárias do Rio de Janeiro - O Correio Mercantil; O Diário do Rio de Janeiro; O Jornal do Commercio - o Jornal dos Tipógrafos traz impresso em suas páginas o seu próprio processo de criação, intensa atividade intelectual e organizativa, com resultados formativos para a categoria e para as classes trabalhadoras em geral. Em cada edição a história do surgimento do jornal e os motivos da greve eram contados ao público em narrativas que incluíam a análise das condições de vida: a carestia; o oferecimento da estratégia: a greve, e sua avaliação a procura de soluções para as consequências: a edição do jornal. Em sua primeira apresentação ao público, assim se pronunciaram os tipógrafos:

Em princípios de dezembro de 1857 , tendo esses gêneros conservado a mesma carestia, se não aumentado, e tendo-se elevado os aluguéis de casas, os feitios de todas as obras e por consequência de tudo quanto é necessário à existência e considerando que nos era impossível sustentar as nossas famílias e aparecermos nas oficinas decentemente vestidos como é uso de nossa arte, por isso que temos de tratar mais ou menos, com pessoas de certa posição social, pedimos aumento de ordenado, conforme fosse possível nos ser dado. Nesse momento qualquer quantia seria aceita por nós embora não satisfizesse nossas precisões.

Porém, mandou-nos esperar para o princípio do ano, e então tivemos em resposta não serem aumentados nossos salários. (...)

Julgamos que as empresas tinham outros recursos e por isso esperamos, porém vendo que ontem, 9, não saíram os jornais aí apresentamos ao respeitável público essa pequena folha como a indenização daquelas que involuntariamente fomos a causa de não saírem (Jornal dos Tipógrafos. 10 de janeiro de 1858).

Assinando as matérias, A Comissão em nome dos tipógrafos era a responsável pela ação organizada apoiada também pela Imperial Associação Tipográfica Fluminense. Da leitura de vários números preservados do jornal que era diário, cabe destacar três aspectos: a capacidade de interpretação do contexto e da correlação de forças em que se inseriam; a compreensão das formas 
de agir da própria imprensa; a disputa travada com o senso comum sobre a capacidade intelectual dos trabalhadores.

Diferente de muitos órgãos classistas surgidos nas três últimas décadas do século XIX e intensificados nas primeiras do século XX, o Jornal dos Tipógrafos não entrava em embates contra a ordem estabelecida. Ao contrário, justificava as ações dos grevistas e procurava legitimá-las de acordo com a ordem.

Ao passo extremo que acabamos de aventurar a favor dos nossos vitais interesses; a medida enérgica e plausível que incontinenti aceitamos em prol de nossos direitos individuais legitimamente garantidos pela constituição do império tido dos redatores das meias folhas diárias as classificações de coligação, temeridade, precipitação, loucura, irreflexão..., apresentando-nos assim aos olhos de uma população inteira, sob o peso de um anátema repugnante, de uma sentença ridícula, que constituem o arbítrio revoltando os mais degenerados sentimentos e a razão mais desvairada. (...) Homens do progresso, moralizados e exemplificados pelas patrióticas lições de liberdade, que se acostumaram a transcrever com os componidores e a inteligência ditadas pelos mentores das redações; cosmopolitas do trabalho; educandos dessa civilização que se projeta e se transmite pela palavra impressa nada nos custará a continuidade da resignação de uma tutela absurda, desde que nossos interesses e sagrados direitos fossem dinamizados na proporção dos lucros fabulosos e infinitos privilégios dos que por longa data nos observaram a subordinação, moralidade e sacrifícios que lhes tem acastelado fortuna e posições (Jornal dos Tipógrafos. 12 de janeiro de 1858).

A ação era plausível, fundamentada na constituição, ao contrário das acusações dos proprietários das folhas diárias de precipitação, que a classificavam como loucura e irreflexão. Apesar de serem acusados de coligação, afirmam estarem defendendo seus direitos individuais. Direitos estes nos quais teriam sido socializados como "educandos daquela civilização". Tal educação os habilitaria em suas reivindicações.

Que muito era que os tipógrafos se voltassem, e com reverência de súplica, com a deferência da expectativa, pedissem por seu turno um aumento diminuto aos seus vencimentos - se eles estavam acostumados a ouvir partir das salas adjacentes onde as ventiladas questões de interesse público vinham direitas e com a previdência de véspera a seus ouvidos - essas reclamações e exigências aos governos, em favor das classes proletárias vitimadas pela carestia dos gêneros??? (Jornal dos Tipógrafos. 12 de janeiro de 1858).

Explicitando as contradições de seus opositores, lembra que a opinião dos tipógrafos fora formada pelos próprios artigos que tinham por responsabilidade compor, contendo reclamações e exigências aos governos em favor das classes proletárias vitimadas pela carestia dos gêneros. Demonstrando aguçada capacidade de interpretação das correlações de forças em que se inseriam, os tipógrafos procuravam valer-se da proteção do imperador devido ao status de sua Imperial 
Associação Tipográfica, na luta contra os empresários das folhas.

No dia 9 esses operários foram procurar o ilustre presidente da Associação a que estavam ligados e pediram-lhe a sua mediação em negócio tão sério. A resposta que obteve o presidente de uma associação respeitável, porque tem por protetor o nosso Augusto Monarca, e demais o homem com uma posição independente entre os seus colegas foi o insulto mais solene lançado a homens que tem o pundonor de uma educação social. (...) Hoje, felizmente, as nossas circunstância mudaram pela proteção e simpatia que havemos encontrado nessa briosa e protetora população (Jornal dos Tipógrafos. 12 de janeiro de 1858).

Os insultos recebidos pelo presidente da associação, mediador dos conflitos, feriam um protegido do monarca. Nesse contexto torna-se mais fácil compreender a extrema importância atribuída ao título de imperial para uma associação de trabalhadores. Ele legitimaria uma ação que era rebelde, mas em favor dos costumes, como aponta Thompson (2008). Mas, num momento de mudanças sociais, formação de um esfera de atuação pública, de uma opinião pública, crescimento urbano, processo de abertura do antigo regime...vemos que os tipógrafos compreendem novamente a conjuntura e buscam refúgio não só ao lado do imperador, mas também "na simpatia dessa protetora população". Esta que procuram trazer para seu lado quando afirmam que "Temos empregado moderação e abandonado todo e qualquer terreno que parecesse significar uma guerra desrespeitosa". Ou seja, os tipógrafos entram no embate social, mas procuram firmar um consenso a seu favor por meio de sua propaganda, atitude que bem aprenderam em sua experiência no meio da imprensa - defender uma posição política com ares de neutralidade. Da mesma forma que haviam aproveitado as notícias veiculadas pela grande imprensa com críticas ao governo imperial, apropriaram-se das rusgas entre aquela e o chefe de polícia da Corte.

Quem se recordar da maneira descomunal que agredistes o Exmo chefe de polícia por ter este conspícuo magistrado mui judiciosamente reprimido os audaciosos pateadores do teatro, que juízo formará de vós?

Quem vos viu há pouco irrogar graves, injustas e imerecidas censuras ao Exmo chefe de polícia e ao seu digno primeiro delegado, taxando de arbitrária, vexatória e imoral a matrícula das meretrizes, o que dirá de vós, vendo-vos, agora, recorrer sofregamente à polícia solicitando uma medida despótica e odiosa contra homens inofensivos?

Para o complemento de vossa obra meritória, invocai também da polícia que intervenha contra os monopolizadores dos gêneros alimentares, e contra os proprietários dos prédios para que aqueles vendam os seus gêneros e este aluguem seus prédios pelo preço que a polícia taxar.

Fazei isto senhores, fazei mais este serviço à humanidade, dai mais esta prova do vosso patriotismo, fazei com que a polícia imponha o preço a todas as coisas e severamente puna aos recalcitrantes às suas determinações dilatadas pelo princípio da liberdade constitucional por vós estabelecida (Jornal dos Tipógrafos. 12 de janeiro de 1858). 
Os tipógrafos procuraram aliar-se ao poder tradicional do chefe de polícia contra o "novo" poder burguês do empresariado da notícia que os afetava diretamente. Seus pedidos feitos sempre com "reverência de súplica e deferência de expectativa" compunham sua argumentação dentro da ordem da sociedade imperial, por suas brechas, sem travar um embate frontal. Os tipógrafos não se filiavam a uma "consciência de classe" do proletariado, opondo-se quando comparados e fazendo questão de não terem sua imagem associada a de outros trabalhadores como os acendedores de gás, considerados por eles trabalhadores "menos nobres" intelectual e socialmente.

Mas, apesar de apoiarem o chefe de polícia em determinado momento, não abriam mão da crítica em outro, como na nota denominada: "Pedestres", em 15 de fevereiro de 1858, onde denunciam a arbitrariedade policial contra uns "pobres pretos".

Ontem revoltou-nos inteiramente vermos a patrulha de pedestres que rondava a Rua do Ouvidor à tarde chibatar sem mais nem menos à uns pobres pretos que estavam parados no canto da Rua Direita, a ver a comitiva dos máscaras que então passava, assim como muita gente ali estava para o mesmo fim. Ora, se eles estivessem em assuada transial (sic.), mas como acima dissemos, vendo o que nós e muita gente vimos... Não é essa a primeira vez que temos sido testemunha de fatos idênticos e mesmo quando os tais pedestres (não são todos) levam algum preto preso, tomam por divertimento irem refrescando (expressão deles), quer o preso resista, quer não, e o mesmo fazem os subordinados do corpo policial; estes até com livres. Chamamos a atenção do Sr. Chefe de polícia para estes fatos a fim de que não se reproduzam, ao menos tão a miúdo.

Já em 11 de março de 1858, o governo provincial da Bahia também não é poupado de críticas que tomam o partido dos oprimidos envolvidos em revolta na capital. Ou seja, não havia uma defesa sistemática dos tipógrafos às autoridades do Império. Apesar de não concordar com os meios violentos e a sedição adotada mesmo por causas justas, responsabiliza o governo e não o povo pelos tumultos, pois compreende a carestia e a exploração do operário, motivos que teriam levado eles mesmos, tipógrafos à greve.

Além do embate intelectual travado com a grande imprensa, vemos na folha tipográfica o combate travado com o senso comum que desqualifica a inteligência do trabalhador, no caso, o artista. Seguindo a lógica da deferência como a forma para um conteúdo rebelde, vemos a incorporação do discurso hegemônico sobre a incapacidade intelectual e ignorância dos artistas para em seguida ressignificá-lo. "Baldo de inteligência, nos faltando mesmo o dom da palavra, não podemos escrever um artigo ornado de atavios, embelezado de pomposas palavras, julgando, pois, inteiramente supérfluo semelhante estilo, falaremos ao público com a linguagem do artista, a linguagem, porém, da verdade". Seu discurso possuiria menos retórica, porém mais verdade, fundado na concretude dos fatos. Questão não apenas de estilo, mas de opção política e 
pertencimento social. O tipo de discurso tinha a ver com quem falava.

Eles a concepção e nós a palavra; eles a cabeça e nós a matéria orgânica, mal pensavam que os nossos braços se cruzassem ante a prepotência e que metamorfoseada em concepção a cabeça, consumássemos a realidade de nossa emancipação! Mal pensavam que as cabeças que se descobriam nos bons dias às cabeças cobertas, em vez de se asfixiarem à míngua, na ociosidade, quando a porta da rua lhes fosse apontada, imponentes e laboriosas lhes pedissem passagem no dia seguinte, para se erguerem no mesmo plano do jornalismo! (...)

Quem somos? Concepções, cabeças e braços centuplicados numericamente, que tomando por juízes um povo inteiro que nos aplaude e justifica, em vinte e quatro horas demos-lhe uma folha diária que já não pode morrer sem que um cataclismo geral marque-lhe o passamento!

Ao mostrar que o trabalhador não era "só braço" e sim cabeça, concepção, viravam de pernas para o ar concepções hegemônicas sobre os saberes ou "não saberes" das classes trabalhadoras.

Adotando uma perspectiva bastante diferente do Jornal dos Tipógrafos, mesmo porque possuía outras "concepções", não sendo órgão de nenhuma associação de classe e defendendo abertamente a transformação social inclusive de forma violenta, A Revolução (21 de abril de 1881) se aproxima dos compositores tipográficos na crítica à retórica vazia e aos discursos sem prática. Polêmica ataca uma das figuras consideradas mais progressistas na segunda metade do século XIX em função de sua postura abolicionista que do ponto de vista daquele periódico, era pouco avançada.

Está a aportar em nossas plagas o sr. Joaquim Nabuco, distinto deputado pela província de Pernambuco. (...) Reconhecemos de sobejo a inteligência deste novo candidato que aí vem para engrossar a fileira dos candidatos que já são conhecidos.

Distinguiu-se ele na câmara temporária por lindíssimos discursos acadêmicos e tornou-se a seu modo o mais ousado propugnador da abolição do elemento servil.

Dizemos a seu modo porque na posição que assumiu o talentoso e jovem deputado não vimos favor algum a essa magna questão que deve preocupar vivamente o pensamento de todos os brasileiros.

(...) porquanto tornou-se contraditório e reconheceu o direito da escravidão quando no seu projeto propôs que esta continuasse até 1890 . Se a escravidão é uma violência ao direito e se este é coisa tão respeitável que deva exigir seu reconhecimento, é obvio que propor a continuação por mais dez anos é reconhecer ipso facto legitimidade na escravidão e transigir com ela.

(...) Desejáramos que s. ex. Houvesse proposto a extinção imediata do elemento servil...

Queremos a prática, a realidade e não discursos, porque de discursos estão cheios os anais parlamentares.

O que temos visto até aqui encontra paralelo com a afirmação feita por Thompson (2002) 
para a Inglaterra no início do século $\mathrm{XIX}^{88}$. Concebendo a leitura e a escrita como uma técnica o autor afirma que, para além de um processo de alfabetização da população, o que se viu foi o desenvolvimento, naquele momento, de maneira bastante autodidata entre os trabalhadores, de uma cultura intelectual e uma consciência política. Cultura na qual a alfabetização assumia grande importância, mas não era imprescindível para a inserção dos trabalhadores em seus códigos. Basta retomarmos a tão ilustrativa imagem com que abrimos este capítulo, cena de alguma padaria do Rio de Janeiro, ou, talvez, da sala da Associação Cosmopolita Protetora dos Empregados em Padaria.

O jornal O Panificador (11 de fevereiro de 1900) traz um comentário sobre artigo publicado no Jornal do Brasil por um anônimo que assina como A. Mercúrio. Este atribuía a responsabilidade pelos problemas da indústria do pão aos donos de padaria por não serem rígidos o bastante com seus empregados. Opunha, dessa forma, o interesse da indústria do pão aos interesses dos trabalhadores e considerava que estes estariam sendo beneficiados. Pelas páginas do jornal dos padeiros temos acesso a duas respostas dos trabalhadores a essa investida. Primeiro, a publicação da crítica pelo órgão da categoria. Segundo, a reação à notícia do Jornal do Brasil por aqueles que “a ouviam ler".

Leitura e escuta politizadas, não era transmitida mecanicamente uma notícia, nem escutada displicentemente. Sujeitos que compartilhavam suas experiências encontravam-se reunidos. A leitura, desde o início, despertava-lhes a manifestarem perplexidade. Parte do efeito das palavras era produzido pela interpretação do leitor: a suspensão da leitura em momento crucial aumentava a surpresa. E a reação final, ponto alto da crítica: gargalhadas de descrédito ao que consideravam absurdo - os empregados, produtores expropriados do fruto de seu trabalho, considerados culpados pelo "fatalismo que pesa sobre a indústria do fabrico do pão". Postura irônica, satírica, segura daquilo que viviam e sabiam.

\section{4- Representações de educação}

Atentos ao debate social sobre educação, os órgãos de imprensa da classe trabalhadora também veicularam suas representações particulares sobre o assunto. Em sua quase totalidade estas

\footnotetext{
88 “...Pois na primeira metade do século XIX, quando a educação formal de grande parte do povo se resumia a ler, escrever e contar, não foi absolutamente um período de atrofia intelectual. As vilas e até aldeias ressoavam com as energias dos autodidatas. Dadas as técnicas elementares da alfabetização, os diaristas, artesãos, lojistas e mestres-escolas punham-se a aprender por conta própria, individualmente ou em grupo (...) aqui e ali, líderes radicais locais, tecelões, livreiros, alfaiates reuniam pilhas de periódicos radicais e aprendiam a usar as publicações do parlamento, diaristas analfabetos nem por isso deixavam de ir, todas as semanas a um bar onde lia-se em voz alta e discutia-se o editorial de Cobet. Assim, a partir de sua experiência própria e com recurso a sua instrução errante e arduamente obtida os trabalhadores formaram um quadro fundamentalmente político da organização da sociedade. (...) De forma nenhuma, o analfabetismo (devemos lembrar) excluía os indivíduos do discurso político" (THOMPSON, 2002, p. 304 e 305).
} 
representações eram positivas, a instrução era entendida como forma de melhorar a condição social do artista e, mais amplamente, promover o progresso da humanidade. Assim justifica seu aparecimento no cenário da imprensa fluminense, O Proletário, “... resultado da firme vontade de alguns poucos artistas que desejavam melhorar sua condição social pela instrução e (...) como qualquer outro (oxalá tivéssemos muitos imitadores) nossa divisa é progresso, nosso fim instrução".

Estes "poucos artistas" representam uma parcela das classes trabalhadoras, geralmente mais instruída, que assume papel de liderança, atribui-se como missão "educar", "guiar" a classe e por conseguinte também legam grande valor à instrução. Estes sujeitos, não raramente, referem-se à maioria dos trabalhadores como apáticos e indiferentes, condição que justifica ainda mais "a missão" que se atribuíram. O mesmo periódico assim a definia: “Tratar dos direitos e deveres do cidadão, pugnar pelo seu bem estar, arrancar a máscara do poder, pedir instrução e proteção para o povo, moralidade dos funcionários, união dos artistas, tal é nosso fim e nossa missão". Quando estudamos as aspirações das associações mutualistas no capítulo 2 vimos que a instrução, no discurso daquelas entidades, era inserida entre os fatores econômicos que garantiriam os meios de vida aos trabalhadores. Ao estudarmos as concepções da imprensa operária vemos a instrução inserida entre fatores políticos, como direito a ser adquirido e ao mesmo tempo condição para exercício de direitos.

Em Echo Popular. Órgão das Classes Operária, Comercial e Industrial (8 de março de 1890), a escola pode ser entendida como espaço de seleção com paralelo na escolha dos representantes do povo no governo. É sobre esse tema que versa o "Exemplo Edificante" publicado naquele jornal. O exemplo deveria ser dado ao povo trabalhador, num contexto em que "se tratava de fazer uma realidade a igualdade de direito perante a representação nacional". O pequeno texto conta a história de Henrique Cheatham, “... um preto deputado pela Carolina do Norte ...”. Ele teria chegado a tal posto, apesar de ter nascido escravo, por seu esforço de trabalhar e procurar por instrução. Foi aluno de destaque na escola, atingiu a Universidade e se tornou diretor da Escola Normal da Carolina do Norte. Que exemplo se extrai dessa história? Não importa a origem social, a instrução seria capaz de formar um bom representante parlamentar. Entretanto, os altos postos da política não estariam abertos à média, ou à massa, das classes trabalhadoras, mas sim aos "bons alunos", no caso do universo operário, à algumas exceções que conseguissem transpor as "barreiras sociais".

Por outro lado, O Proletário não compreende instrução como prerrogativa apenas da escola e delimita fatores educacionais que coincidem com os defendidos na presente tese como meios do "educar-se das classes trabalhadoras".

Milhares de tentativas têm sido feitas, ora criando-se associações onde se discute e anima, aconselhando o estudo como único meio de melhorar a 
condição do operariado, ora órgãos que por sua vez discutindo, defendem os interesses conspurcados dos mesmos operários, mas debalde após vem a indiferença e essas associações, esses órgãos, caem exaustos à míngua de recursos, e do pouco ou nenhum caso dos que deviam ligar-lhes a máxima consideração (O Proletário. 17 de novembro de 1877).

A valorização das letras e do estudo estava ligada a defesa das associações e periódicos de classe. Estes, porém, tenderiam a cair exaustos devido à indiferença dos trabalhadores. Mas, apesar da indiferença tão reclamado pelas lideranças trabalhadoras, não deixam de conclamar os operários, abusando das exclamações ao fim das frases: “Operários e nossos colegas!!! temo-nos esforçado como vedes com a criação desse órgão - O Proletário - agora a vós compete o dar-lhe vida, auxiliando-o. Guerra à inércia, a indiferença às letras e avante!!!”. Assim acreditam que poderiam reverter a condição da maioria das classes operárias, seria uma questão de educá-las. A possibilidade de mudança de comportamento pela educação seria viável uma vez que, aquele estado de apatia das classes trabalhadoras não seria resultado de uma "natureza apática". Segundo $O$ Socialista (20 de julho de 1878), a indiferença seria "a tumba em que as classes privilegiadas sepultaram-no [o povo ${ }^{89}$ ] pelo punho brutal do poder".

A Revista da Associação dos Guarda-livros (30 de abril de 1874) também defendia meios além da escola para a categoria educar-se. Em um de seus artigos "A Propósito das Bibliotecas", valoriza a ação das associações literárias e científicas como "arsenais de guerra à ignorância" e às "trevas do espírito" de grande parte da sociedade. As bibliotecas públicas seriam ainda “... um dos elementos mais fortes para a instrução pública, de cujo desenvolvimento depende a marcha rápida do progresso e do aperfeiçoamento dos costumes”. Movido por essa concepção, pede o auxílio à biblioteca da associação que poderia se encontrar em melhor estado, visto a grande valorização dada pela classe dos guarda-livros aos estudos, no que entrevemos traços de autodidatismo.

... a classe dos guarda-livros além de não ser refratária à lei do trabalho, procura ilustrar-se por meio do estudo de todos os ramos dos conhecimentos humanos, na convivência íntima de alguns bons mestres, que a nossa biblioteca já proporciona, e que mais facilitará de futuro se os esforços da Diretoria, ajudados pelos bons desejos de todos os Srs. Associados, concorrerem para o seu engrandecimento.

Ao tomarmos um periódico editado por sujeitos portadores de títulos superiores, como era o caso dos editores de $O$ Artista (27 de janeiro de 1870), todos engenheiros, ainda que o principal deles, o tenente coronel Fernando Luiz Ferreira fosse considerado "artista ele mesmo" encontramos uma concepção educacional semelhante em essência. Para seus autores "todo homem precisa de instrução" e essa questão, “aliás, parece evidente". O que eles procuram em seu programa é definir

89 Os termos: classe operária, operário, povo, trabalhadores, artistas, na maior parte dos textos dos periódicos aqui analisados são entendidos como sinônimos. 
que instrução é essa, e fazer com que o jornal auxilie-a. Seria necessária "a todo cidadão": a instrução geral e principalmente a profissional.

A instrução geral de que precisa é: saber ler, escrever e contar, conhecer um língua estrangeira para poder estudar a parte técnica de sua profissão, e acompanhar os progressos que esta faz em outros países, que possa apreciar o movimento político do país, ajuizar do valor das leis que se decretam e dos homens incumbidos de sua confecção, de julgar segundo elas e fazê-las executar.

Quanto à instrução profissional, nenhum artista deve dispensar o conhecimento de aritmética, da geometria e do desenho linear como estudo preparatório além daquele que se refere especificamente à arte que professa.

De qualquer profissão que seja o artista ele lucra em ter noções de física e de mecânica, assim como não pode dispensar alguns conhecimentos de economia política se quiser sobressair em sua profissão e ocupar um dia o lugar de chefe de indústria como proprietário ou como simples gerente.

O estudo do movimento político do país é de suma importância, porque a classe laboriosa interessa saber como se organiza a milícia, da qual ela tem de fazer parte, como se distribui o imposto que ela paga, direta ou indiretamente, como se garante a propriedade que ela também possui, a liberdade de que necessita em todos os seus movimentos, etc (O Artista. 27 de janeiro de 1870).

Essa gama de conhecimentos idealizados formaria não só para o exercício da função, mas para a vida social, uma vez que "para merecer o nome de cidadão, para ser digno de chamar-se homem é forçoso que raciocine e se habilite para julgar”. Seria necessário que o homem tivesse “certo grau de desenvolvimento intelectual para julgar". Até aqui seu posicionamento é compatível com a visão dominante sobre a relação entre instrução e política, porém encontramos um diferencial em seu discurso: o homem pode saber ler e se manter ignorante sem o tal grau de desenvolvimento intelectual.

Entretanto na política, muito mais do que no jure é preciso que o homem tenha certo grau de desenvolvimento intelectual para poder julgar mesmo depois de ouvido os debates. Com efeito o homem completamente ignorante não compreende sempre as discussões da imprensa e nunca sabe quando lhe compete julgar como juiz de direito, quando deve se transformar em poder executivo. Julga sempre como mero juiz de fato e aí fica.

O homem inteiramente ignorante, mesmo sabendo ler, não pode acompanhar o movimento político do país, formar juízo sobre as medidas tomadas ou a tomar, essa instrução não é suficiente para que tire uma conclusão exata só pelos debates da imprensa, e em muitos casos, direi mesmo, em quase todos precisa ter certas noções.

Todos já bradamos que é preciso saber ler, abrir escolas, fazer o ensino obrigatório (debaixo de certo ponto de vista) e não nos demorarmos em pensar que não vale muito o saber ler se não se achar onde ler coisas úteis. Ler, simplesmente, é estar diante da porta aberta de um rico edifício sem poder entrar em seu interior porque há uma segunda porta que o fecha $(\mathrm{O}$ Artista. 27 de janeiro de 1870). 
Percebemos um tom crítico nas relativizações sobre o que significaria ler sem ter o que ler e a insuficiência de só se abrir escolas. No mesmo artigo segue a crítica da existência de poucas publicações e seu alto custo associado ao problema da linguagem incompatível, distanciada da realidade da maior parte do povo. Incompatibilidade de linguagens que não acomete só as obras literárias, mas também o discurso político:

Se o nosso país não está mais adiantado em política, é certamente porque os políticos não se demoraram em pensar que fala-se e escreve-se para ser-se compreendido, pois que do contrário é inútil falar ou escrever, perde-se tempo. Para os homens da mesma força não é preciso longa discussão para chegar ao acordo, estando de boa fé, quando assim não acontece é porque um deles é o cego da escritura, não quer ver.

Querem que o governo do país seja o do povo e pelo povo, falem ao povo de modo que ele compreenda, plantem-lhe no espírito princípios que sirvamlhe de guia como a estrela polar serve ao navegante (O Artista. 27 de janeiro de 1870).

No caso da imprensa, $O$ Artista critica o fato de que o "homem ignorante" tem sido posto de lado, não há preocupação de instruir-lhe e mesmo um ou outro periódico com denominação de popular incorre na inadequação da linguagem ou "querem tornar-se compreensíveis a força de frivolidade".

O que chama atenção nos textos de $O$ Artista é o encontro com uma representação mais ampla de educação e certa sensibilidade com que compreende o povo como capaz de adquirir conhecimentos tanto quanto outras classes da sociedade desde que se lhe apresente a utilidade desses conhecimentos, ou, numa perspectiva menos utilitarista, que se apresente a relação desses conhecimentos com seu cotidiano.

A favor da criação de escolas, da difusão da instrução primária têm se erguido muitas vozes, tem-se empregado muito esforço, aliás insuficiente para a vastidão desse país e para o que se deve desejar: a Constituição garante gratuitamente a instrução, mas tem se entendido que isso importa em garantir escolas primárias em todos os povoados, secundárias nas capitais, e superiores na Corte e numa ou noutra província; particulares, sociedades têm aberto escolas em diferentes lugares, mas não se tem pensado no meio de dar a instrução mais sólida, mais útil, diremos em apresentar bons livros em língua portuguesa para a instrução dos que sabem ler. (...)

O povo pesa em geral que a vantagem da instrução primária está em poder ler ou escrever uma carta, e como em geral os seus negócios não exigem imperiosamente que leiam ou escrevam, eles deixam de empregar esforço para que seus filhos vão à escola.

Comece o agricultor de poucas forças a ler um livro ou ouvir ler, como associando-se ao seu vizinho ele pode colher o dobro do que trabalhando só; ouça ler como um homem fez utilizar um vegetal a que até então não se dava importância e enriqueceu por esse meio, ouça ler o artista que o que inventou a máquina de coser, o tear de tecer, etc. enriqueceram ; que se não 
souberem ler terão disso pesar e mandarão seu filho a escola. (...)

O povo habituou-se a não ler e pensa que a leitura não pode trazer utilidade, porque de fato nunca obteve do que leu. Mesmo os homens instruídos ficam desnorteados quando leem a maior parte dos artigos impressos em nossos jornais e se não tivessem fundamento para não duvidar de si, certamente que não duvidariam dos outros.

O povo duvida de si, e por isso desiste do intento, foge das letras, que só servem neste caso para fazer perder um tempo precioso de que precisa para seu trabalho.

O trabalho produz um salário no fim do dia, o lucro da instrução é remoto, se não o compreende, se não acredita nele, se a sucessão das ideias não prende-lhe a atenção, para que há de ler?

Assim pensa o povo (O Artista. 29 de janeiro de 1871).

Trata-se aqui de uma crítica à própria política educacional do Estado Imperial e à concepção corrente de educação do povo como instrução elementar. Associa aprendizagem à condições socioculturais e, ainda que atribua ao povo uma forma de pensar utilitarista, busca uma lógica própria na visão destes sujeitos sobre educação. "O povo não lê" é a verdade propagada. Ao se deparar com determinados textos, "o povo duvida de si". Pudera, segundo o autor, mesmo os homens instruídos ficam atordoados quando leem a maior parte dos artigos impressos [nos jornais da Corte]". Os homens instruídos tinham respaldo social para não se colocarem em posição de inferioridade frente ao texto, respaldo que falta aos sujeitos estigmatizados, não só por sua pouca prática no universo letrado, mas por outros fatores sociais, econômicos e culturais vinculados.

Apesar da grande valorização do saber letrado, os saberes de ofício não deixavam de ser valorizados. Em palestra realizada pelo trabalhador, Sr. Silveira, na sala da Liga Operária, cujo resumo foi publicado por $O$ Proletário (17 de novembro de 1877), vemos que muitas famílias consideram o "oficial de ofício" como má condição. Essa desvalorização tem a ver com o fato das “classes mais elevadas da sociedade" educarem seus filhos para carreiras científicas e empregos públicos. O orador, pelo contrário, lembra-se do que diz um "antigo adágio”: “... quem tem ofício tem benefício". Esse saber não dispensaria a formação escolar, defendida pelo Sr. Silveira. Tanto aquela oferecida pela própria Liga Operária, que segundo ele, contribuía para "tirar o operário das trevas", e deveria ser frequentada por meninos e por adultos como a que deveria ser cobrada do Estado. Aconselhava que por meio da própria Liga, se “... [representasse] ao governo pedindo proteção para o artista, e quanto aos arsenais, aulas nas quais os aprendizes tenham conhecimentos técnicos dos ofícios que aspiram saber ...”.

O mesmo periódico corroborava a valorização da capacidade intelectual dos trabalhadores na homenagem feita a Gutemberg, de quem relembra a identidade de operário. "E na Alemanha passava impávida e triunfante por entre as nações estupefatas levando diante de si, coroado de louros, a um simples operário que, escarnecido pela sociedade e malbarateado em sua própria pátria 
fez-se - nobre - pelo trabalho, pela perseverança e por essa centelha divina que se chama gênio" (O Proletário. 9 de dezembro de 1877).

Instrução e trabalho estavam, portanto, intimamente relacionados. A frase de efeito contida em Gazeta Operária (8 de janeiro de 1881) representa bem esta ligação: “A instrução é um tesouro, o trabalho é a chave para a abrir". A mesma definição estava presente na Revista da Associação dos Guarda-livros (31 de janeiro de 1874) que faz da articulação entre esses dois termos, a fórmula para um futuro de felicidade e engrandecimento. Em sua vida de "operários modestos e pobres, que cheios de fé no porvir aglomeram materiais para o seu futuro edifício em cuja fachada ler-se-á em caracteres simples, porém indeléveis - TRABALHO E INSTRUÇÃO - porque estamos convictos que essas curtas, mas extensíssimas palavras encerram o mais augusto incentivo para a felicidade e engrandecimento da humana vida".

A instrução ajudava a definir a identidade de uma categoria, sua imagem perante a sociedade como um todo. É este um dos intuitos expressos no artigo "A Redação" marcando o número doze da Revista da Associação dos Guarda-livros (31 de dezembro de 1874). A apresentação de seu movimento intelectual visava alimentar sua identidade e valorizar a categoria diante dos comerciantes.

Entendemos estabelecer como ponto de partida, isto é, tratar primeiro que tudo da exibição do nosso movimento interno, porque nisso ia e vai sem dúvida alguma uma satisfação especial aos comerciantes que tão mal nos julgam e que tão importância ligam aos seus verdadeiros agentes, os Guarda-livros: tínhamos necessidade de provar-lhes a toda luz que nas reuniões semanais que não se dispendem inutilmente, o tempo, pelo contrário, é aplicado ao estudo de questões práticas e teóricas, às que ilustram o espírito, à interpretação da lei do comércio e à discussão de problemas de interesse comercial e social. E em segundo lugar, o tempo e o espaço que nos sobrassem, dedicá-los à solução de questões do interesse do país, ao bem público e por fim e por fim, contribuir com os fracos recursos de nossa inteligência para a grande obra da regeneração nacional. Acreditamos que empregados como somos no comércio, envolvidos de contínuo no labirinto das cifras e por isso conhecedores e práticos de todos os elementos de prosperidade a indústria comercial, bem como de todas as dificuldades que a oprimem poderíamos muitas vezes apontar o mal, indicar o remédio, clamar pelo seu emprego e discutir com mais ou menos aproveitamento as causas de interesse comercial e público.

Utilizando a retórica da modéstia ao referir-se aos "fracos recursos de nossas inteligências", apresentam-se como estudiosos e capazes de, a partir de seus saberes práticos de empregados no comércio, contribuir com as causas de interesse comercial e público. Em última instância, teriam lugar na "grande obra de regeneração nacional".

Em sua posição de trabalhadores ilustrados, a Revista da Associação dos Guarda-livros (30 
de abril de 1875) critica a falta de investimento na instrução pública por parte do Estado que deixava de investir neste ramo para aumentar despesa com que era proveito seu [da Câmara de Deputados].

A comissão do orçamento da câmara dos Srs. Deputados propôs em terceira discussão que se fizesse reduções na despesa com a instrução primária e secundária na corte. É muito para estranhar que não visse a comissão do orçamento da despesa senão a verba da instrução pública digna de sofrer cortes quando é conhecido que muitas outras existem merecedoras de grande redução, a começar pelo subsídio da câmara. Mas com esta verba trata a câmara de aumentar a despesa e não de a reduzir visto que o proveito é seu.

Denúncia de um tipo de tratamento dispensado à instrução que, de acordo com as concepções dos guarda-livros, poderia ser classificado com herético, para eles que tinham na ignorância o "pecado original", e no estudo a sua redenção. Cabe ressaltar, entretanto, que como podemos perceber na passagem a baixo e em todo o corpo da revista dos guarda-livros, instrução não era sinônimo apenas de escola, sendo o estudo, a experiência, a reflexão, o raciocínio, extremamente valorizados por aqueles profissionais. A própria natureza de sua organização demonstrava essa concepção, uma vez que seu objetivo era, antes de tudo, associação elaboração e debate de teses entre pares da mesma categoria a cerca de temas ligados ao desenvolvimento do comércio.

Quanto mais livremente se ilumina nossa consciência, mais se aproxima da divindade. A maior cópia de luz para alumiar o espaço da sua ascensão é a história porque, infelizmente o homem tem colhido todas as suas riquezas intelectuais da longa e amargosa experiência! (...) Caminhar é uma condição essencial e inerente à nossa natureza. Saber qual o melhor caminho, é um bem que só o estudo, a reflexão e o raciocínio podem mostrar, eis porque a razão esclarecida em todos os lugares leva vantagem ao espírito sepultado na ignorância, e eis também porque nós os rapazes de hoje, que devemos ser os homens de amanhã, em vez de consumirmos nosso tempo em veleidades, damos cumprimento ao nosso desejo de ser úteis à humanidade e preparar um futuro alegre e feliz para as crianças que nos hão de suceder, nesta idade de sonhos febris que pode bem ser de realidades úteis (Revista da Associação dos Guarda Livros. 15 de junho de 1875).

A Associação dos guarda-livros não era, porém, a imagem da categoria. Esta seria, de acordo com sua revista, em sua maioria, prática e balda de teoria. Daí a importância daquela organização para os demais trabalhadores do ofício. O artigo “A Nossa Associação” (15 de agosto de 1875) defende que "Esta instituição é tanto mais proveitosa e útil à sua classe, quanto é certo, com exceção de um ou outro dos que frequentaram os cursos das aulas de comércio e dos poucos que possam ter recebido para o mister mais adequada educação, a maioria dos guarda-livros na nossa praça é puramente prática e balda de teoria; torna-se por isso mesmo carecedora da lição e contato de todas as ideias". Vemos instalar-se a polêmica entre teoria e prática. Para o articulista a frase feita 
que diz, em matéria de comércio, a prática valer mais que a teoria, esconderia o fato de que, todavia, "a prática sem o auxílio da lição de teoria não passará de cega e rotineira".

Pendendo para o lado da prática, ou de uma teoria que não se descolasse da prática, $O$ Três de Abril (23 de abril de 1905) também aborda a polêmica. Amaral Chaves, o articulista defende que o estudo deveria se dar por princípio nas "grandes leis da natureza, porque só é aproveitável o natural, porque o artificial é ilusão, necessitamos de estudos práticos porque as teorias já não as compreendemos, queremos doutrinas puras”. A responsável por essa forma de conhecimento que implicaria na "elevação de ideais ao ponto terminal" seria a própria associação dos trabalhadores. Organizados e preparados intelectualmente enfrentariam seus carrascos "mostrando já haver em nosso seio 'um cérebro que pensa e um coração que sente"'. Ou seja, o mundo das ideias abstratas representado pelo "cérebro que pensa" não estaria, enfim, descolado do mundo dos sentidos e da prática representado pelo "coração que sente". Diante de reflexão como esta entendemos melhor o que Gramsci quis dizer ao afirmar que "todo homem é um filósofo", e não menos o homem trabalhador.

A instrução, não raramente, era vista como pacificadora de conflitos. Nas páginas de Lincoln: Periódico do Clube Gutemberg ela teria papel importante a cumprir naquele que era o maior e mais sério conflito do Brasil oitocentista: aquele entre os escravos, ou egressos da escravidão e a ordem estabelecida. Ser abolicionista, educar escravos e libertos, na concepção dos tipógrafos que compunham o Clube, não significava ser "anarquista" e pregar uma revolução social, acusação que, ao que parece, teriam recebido.

... nós não somos o que pensais, anarquistas e revolucionários, mas sim cidadãos que querem a ordem, porque a ordem é a liberdade, que querem a revolução, mas a revolução das ideias que é a instrução, porque é com ela e esta que se pode conseguir a realização das três grandes ideias de que, segundo a frase eloquente do Sr. Visconde do Rio Branco, tem necessidade a nossa pátria: - "Paz, luz e trabalho". Paz para que entre todos os cidadãos se faça a união, que se fortifica no patriotismo. Luz, para que sejamos, pela instrução, um povo digno e respeitado por todas as nações (Lincoln. 1 de janeiro de 1883).

Seguindo os preceitos citados, o Clube Gutemberg anuncia nas páginas de seu periódico a fundação de sua primeira escola ao mesmo tempo em que anuncia a cadeira de vereador em Niterói conseguida pelo presidente do Clube, o cidadão Alberto Vitor. O que nos remete não só a uma visão de educação, mas de um projeto social mais amplo defendido pelos tipógrafos organizados no Clube, no qual a instrução ocupa um espaço central. Esse projeto não existia apenas no "mundo das ideias", mas em intervenções diretas como a criação da escola noturna e o engajamento, impressionantemente bem sucedido, no pleito à Câmara de Vereadores - estratégias condizentes 
com a ideologia de sujeitos que não eram "revolucionários nem anarquistas"90.

Lia-se no jornal o anúncio da escola que segue transcrito: "Escola Noturna Gratuita".

$\mathrm{Na}$ escola noturna gratuita que o Clube Abolicionista Gutemberg inaugura hoje às 6 horas da noite, à Rua das Flores n. 97, em honra ao $20^{\circ}$ aniversário da abolição da escravidão nos Estados Unidos serão admitidos menores e adultos nacionais e estrangeiros, livres, libertos e escravos.

Para a matrícula que se abre hoje nada se exige além da apresentação do pretendente ao secretário do Clube que será encontrado na escola das 7 às 9 horas da noite nos dias úteis e nos demais das 12 às 2 horas do dia.

A escola começara a funcionar no dia 15 do corrente.

É livre a entrada as pessoas que desejarem visitar a escola.

Secretaria, 1 de janeiro de 1883.

O secretário Luiz Pires (Lincoln. 1 de janeiro de 1883).

Entre as lideranças operárias também havia aquelas que associavam instrução e pacificação, ou o reverso, ignorância e uso da violência nos conflitos de classe. Em resposta a um artigo anônimo que qualificava $O$ Três de Abril, órgão da União Operária do Engenho de Dentro, como inconsciente, o primeiro orador oficial da associação manifesta seus acordos e desacordos. O que significaria inconsciência para o "Z”, letra com que assina o acusador anônimo, não é possível sabermos, pois seu artigo não consta nos números lidos.

Mas, nos interessa observar o que era "inconsciência" para $O$ Três de Abril (10 de setembro de 1905) e a sua relação com a instrução. Inconsciente seria o conjunto dos operários que “... reclamam os direitos que lhes foram usurpados, sem, entretanto, poderem explicar o que lhes pertence. Por que isso se dá? Simplesmente pela ignorância em que eles se encontram e pela falta de confiança nos poucos, mas competentes e dedicados defensores que tem tido a classe operária”. Por serem inconscientes, fariam uso de “... maneira [s] excessivamente violenta [s], sem rumo nem ideias porque pedem os operário no Brasil; as greves parciais e sem recursos para a sua manutenção, constituem-se, atualmente, em elementos de anarquia contra o ideal que sustentamos". Essa ignorância e inconsciência os impediria de ver que os capitalistas "por esse fato não deixam de ser nossos irmãos". Essa "cegueira” em que viviam os operários também era motivo de desacordo d' O Três de Abril. Como remédio para a "inconsciência" e a "cegueira" o periódico aconselha-os para que "concorram às aulas diurnas e noturnas mantidas pela União Operária. Sem luz não há quem possa romper a escuridão das trevas!...”. Ou seja, a visão que as lideranças trabalhadoras nutriam sobre a classe não era positiva. Também ela subordinadas à ordem instituída, não pareciam aceitar opiniões divergentes ou ações fora de sua esfera de controle.

90 Temos da polêmica revelada nas páginas do jornal, ao que tudo indica os tipógrafos teriam sido assim acusados por defenderem a abolição e a instrução para escravos. 
Para Elisa Schide, articulista d' $O$ Três de Abril e fundadora do Partido Operário Independente, seriam vãos os esforços do socialismo em suprimir os sofrimentos da humanidade. Para Elisa esses sofrimentos seriam por enfermidade da alma contra a qual só haveria um remédio eficaz: "a influência da civilização". Em seu artigo "A Instrução" defende suas virtudes quase místicas:

Somente a instrução transforma o homem e o conduz a igualdade e solidariedade que é a aspiração da sociedade futura. (...) Nessa ardente fornalha onde os elementos da civilização e da barbaria foram postos em fusão, a violência, a fraude, o homicídio, todos os crimes, todos os vícios, foram vencidos pela virtude, a política até então belicosa e sanguinária tornou-se persuasiva e pacífica porque o pensamento humano, desprendendo-se dos pesados rochedos da terra, voou livre para a grande luz (O Três de Abril. 24 de setembro de 1905).

A representação da educação como redentora podia aproximar alguns jornais de associações trabalhadoras e A Redenção Periódico da Penitenciária do Rio de Janeiro (25 de março de 1914). Este tinha como objetivo "ensinar os que pecaram contra a sociedade os meios de resgatar as faltas passadas, proporcionando-lhes conhecimento de utilidade para a vida e a difundir ideias e sentimentos que unidos sintetizem esse ideal de cultura da qual todos necessitamos para viver com inteligência, com dignidade e com honra". Este "ideal de cultura" reflete-se nos títulos das matérias: Patriotismo; O álcool; Trabalhemos; A Terra; A Descoberta da Vacina; História Brasil; Contra a preguiça...diligência; Máximas Orientais; Pobre, porém honesto...

No artigo “A Economia” (A Redenção. 23 de abril de 1914), os operários são os interlocutores eleitos. Ironicamente o texto defende que "cada um tem dentro de si, inegavelmente, capacidade e liberdade ${ }^{91}$ para determinar suas ações e só com o desejo de querer muitos indivíduos se têm elevado desde as maiores profundidades da pobreza a posições justamente invejáveis". A educação seria um primeiro passo nessa progressão. Seria mesmo um "dever de todo homem (...) educar-se". Outro passo seria a economia, uma vez que, era a falta da economia que impedia trabalhadores de virarem capitalistas. "A maior parte dos operários tem pouquíssimo capital, além do seu trabalho, e unicamente por sua culpa, esbanjam seus salários em lugar de economizá-los e tornarem-se capitalistas”. Da mesma forma que a palavra liberdade é apropriada por um discurso liberal que a idealiza separando-a da prática histórica, o termo educar-se não pode ser confundido com o que propomos na presente tese. Aqui é entendido como as formas das classes trabalhadoras desenvolverem saberes e propagá-los pela via da experiência. Em A Redenção, educar-se significava um movimento de indivíduos e não de uma classe. Movimento em que o homem, no caso o trabalhador, a quem era dirigido o artigo, "desse seu próprio jeito" para obter a educação

91 Grifo meu. 
formal, socialmente aceita.

Para o O Marmorista. Órgão de Propaganda dos Operários Marmoristas, a educação também seria fonte de virtudes, meio de chegar a um estado de perfeição, levando o trabalhador além dos conhecimentos adquiridos na própria prática do ofício. Ela lhe permitiria atingir compreensão e consciência de seus direitos e deveres de cidadão para que viesse a ocupar o lugar que tem direito na sociedade.

Não basta para ocuparmos o lugar que temos direito na sociedade de que somos uma parte integrante, tomar o maça (sic.) e o cinzel (sic.) e com ele em uma pedra tosca e dura, informe, reproduzir a feição humana, seus mínimos detalhes e dar-lhes expressão e quase vida, ficando um homem perfeito. É preciso e eu desejo mais, muito mais. É indispensável que o artista saiba compreender e que tenha inteira consciência dos seus méritos e dos seus deveres e direitos de cidadão. Será uma utopia, um impossível chegar a esse estado de perfeição? Absolutamente não!

A todo tempo é tempo de nos prepararmos, de frequentarmos a escola, é somente uma questão de vontade. Se a oficina não dá aos simples marmoristas de hoje os conhecimentos precisos para ser amanhã um Celline, um Teixeira Lopes ou Pierre Poaget, deixa-lhe em compensação 4 horas absolutamente livres em cada dia útil em que poderão consagrar-se ao estudo, frequentando a escola onde esses conhecimentos lhes são ministrados gratuitamente. Avante, pois, companheiros! Em vez de esterilizarmos as horas da nossa folga em divertimentos que nos prejudicam física e moralmente, isto é, à saúde, o dinheiro e o crédito, aproveitemos frequentando a escola, educando-nos.

A. C. Cristino (O Marmorista. 1 de janeiro de 1907).

A frequência à escola no tempo livre do trabalho, substituindo os divertimentos que na opinião de A. C. Cristino, prejudicariam moral e fisicamente ao trabalhador, era a forma de atingir outro patamar social. Educar-se era empregar seus próprios esforços na obtenção de educação formal. Entretanto, a educação entre os marmoristas aparece associada a um ideal de aperfeiçoamento do ofício - tornar-se um "Celline, um Teixeira Lopes ou Pierre Poaget" - e de cidadania - "inteira consciência dos seus méritos e dos seus deveres e direitos de cidadão" e não ao projeto de "tornar-se um capitalista" que segundo A Redenção também estaria ao alcance de todos. Em que pese a imaterialidade da afirmação contida no periódico da penitenciária, ainda que "se tornar capitalista" estivesse ao alcance de todos, talvez não fosse a vontade de muitos.

No ano de 1884, alguns periódicos da Corte manifestaram-se a favor da abolição dos escravos na Província do Ceará, lançando números especiais por conta do fato histórico, entre eles estavam alguns jornais de trabalhadores como Vinte e Cinco de Março: Homenagem de Alguns Tipógrafos à Província do Ceará e Gazeta Suburbana: Edição Especial Comemorativa da Solene Redenção dos Escravos na Província do Ceará. Nas páginas da edição comemorativa da Gazeta encontramos uma visão relativista de instrução (tema sempre associado ao abolicionismo) pouco 
comum à época. Segundo o jornal suburbano "Tem-se feito grande arruído com a instrução pública. Ainda bem". Mas no meio do grande consenso em torno da necessidade de instruir, não se devia perder de vista que tipo de instrução estaria se promovendo. "Mas tomai sentido que com essa imensa quantidade de erros acumulados nas vastas e pulverulentas bibliotecas não desnorteeis o espírito humano. O essencial é a orientação individual e social. Sem isso podeis caminhar muito, mas não sabeis onde ireis parar. Por falta de orientação os partidos mais adiantados pugnam por uma liberdade que não e outra senão da opressão...”.

Infelizmente não foi possível ler na íntegra o artigo que aparecia mutilado e incompleto, mas o trecho transcrito já nos possibilita pontuar uma visão crítica em que não é qualquer instrução ou qualquer leitura benéfica por si mesma. Ou seja, Gazeta Suburbana, como poucos, reconhecia que não existe instrução ou leitura neutra, daí a necessidade de orientação.

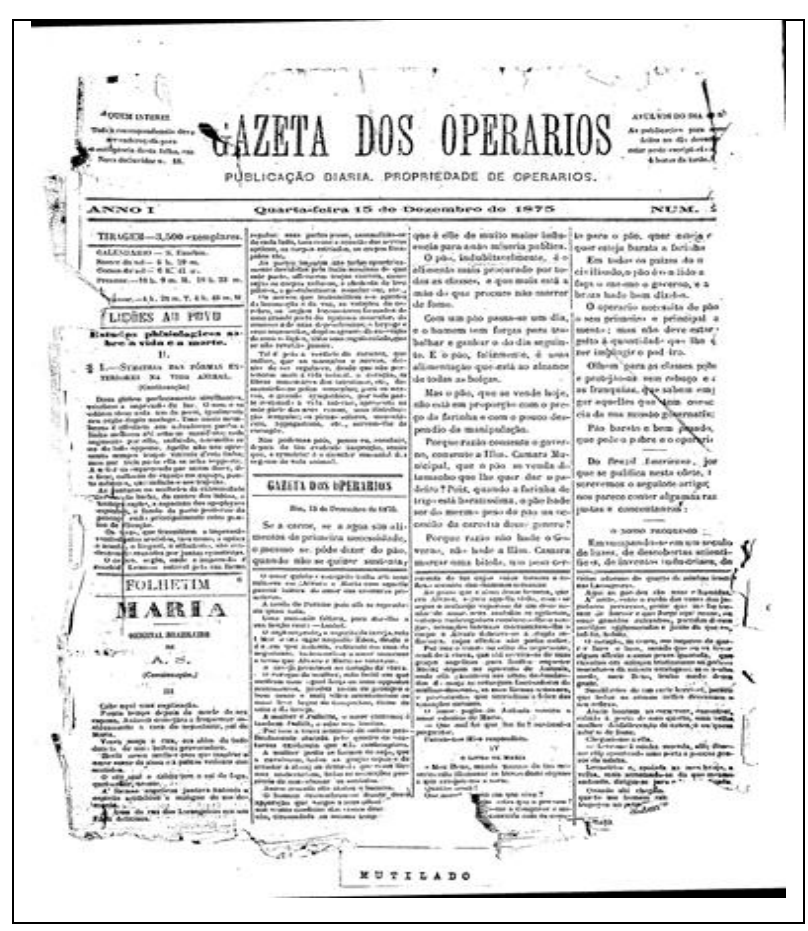

Figura 4- Imagem de exemplar mutilado da Gazeta dos Operários. É relativamente comum encontrar jornais operários do século XIX em condições como esta.

Nesse mesmo sentido, adotando uma visão mais crítica sobre educação, Força Nova (24 de julho de 1904) opera uma inversão no senso comum da "cegueira das classes trabalhadoras" repetido por muitas lideranças operárias, e veiculado em periódicos como O Três de Abril. No artigo “O Individualismo Burguês", J. de Oliveira considera a "cegueira" um problema das classes burguesas, causada não pela "ignorância", mas pelo individualismo.

Não é raro ouvir do burguês embrutecido pelo excesso dos prazeres desse estado de espírito que nada tem de semelhante com a saúde, fitando os 
milhões que representam os sofrimentos, as lágrimas, os gemidos de infinitas vítimas fanfarronar: "Eu não preciso de ninguém, sou rico. Nada peço, nada quero dos outros, prescindo do concurso de quem quer que seja, sou absolutamente livre". Entretanto, o miserável ocupa um homem para temperar-lhe a comida, outro para lhe engraxar as botas, um terceiro para lhe guiar o carro; este trata do jardim aquele do fato, dos filhos, etc. Ele não compreende que é o mais inútil dos seres e que despojado dos tesouros, degradar-se-ia para obter as coisas mais insignificantes, pois que é incapaz do menor esforço. Numa sociedade secular sucumbida de inanição. Ah! Mas o monstro vive iludido porque pé cego e a pior cegueira é a do espírito.

É a mesma inversão que encontramos em O Proletário (7 de outubro de 1877), quando em sua "Atualidade Política", critica os "Aventureiros que tem horror ao trabalho e muito amor ao erário nacional, não trepidam a custa mesmo do sangue do próximo, alcançar um assento no parlamento. Ineptos como são quase na sua totalidade, não têm ideias, seu partido é o governo que os atirou àquele recinto, tendo empregado para tal fim o bacamarte do bandido ou o sabre do policial ...”. O autor procura reafirmar uma cultura bastante presente em vários jornais de trabalhadores, onde o trabalho e o trabalhador têm valor e os corruptos não o tem. Estes representariam o anti trabalhador, eles sim, ineptos e sem ideias.

No artigo seguinte de Força Nova (24 de julho de 1904), intitulado “A Emancipação da Mulher", Maria de Oliveira aponta a educação até então recebida pelo sexo feminino não como fonte de luz, mas como fator de escravidão. A mulher deveria se emancipar de "uma educação viciada e incompatível com o estado de maturidade das inteligências”. Seria a própria educação vigente, fundamentada em "diferentes teorias que até o presente têm sido evocadas com o fim de mantê-la dócil e submissa", um fator gerador de "ignorância e fanatismo".

Considerada pelos inconscientes como um ser inferior, é a mulher objeto de suas invectivas e de seu escárnio. Os filósofos gregos ultrajavam-nas, cobriam-nas de imprecações e os próprios doutores da igreja levaram o seu desprezo ao ponto de discutirem se ela tinha ou não alma. Modernamente os que se dizem sábios comparando o peso do cérebro da mulher com o do homem e achando aquele mais leve do que este, pretenderam constatar a sua inferioridade. Alguns ainda afirmam a supremacia do homem sobre a mulher no fato de ser o cérebro daquele mais rico em circunvoluções, outros, no tamanho do crânio.

Todas estas teorias, porém, são improcedentes, insustentáveis, não se apoiando em dados positivos. Um simples raciocínio basta para tornar evidente meu acerto. Efetivamente, o homem, que se imagina o centro da criação, não consente que outro animal qualquer lhe seja superior em inteligência. Entretanto, se aceitássemos aquelas teorias, acharíamos que o elefante, cujo cérebro é muito mais pesado que o do homem, seria muito mais inteligente do que este, bem como a baleia e outros cetáceos.

Novamente a inversão, “os que se dizem sábios”, reconhecidos filósofos, doutores da igreja, 
são apresentados como inconscientes por sua defesa de teorias que afirmam ser a mulher inferior. Contra as mais recentes tentativas de provar "cientificamente" a incapacidade intelectual da mulher frente ao homem, a autora desenvolve sua argumentação lógica, convidando o leitor a um "simples raciocínio" que bastaria para tornar evidentes suas proposições.

Um tipo de filosofia educacional contra hegemônica que perpassava os artigos de Força Nova (24 de julho de 1904) parece se concretizar também sob a forma escolar na proposta da Universidade Popular cuja inauguração era ali anunciada.

A Universidade Popular, fundada exclusivamente para a educação superior do proletariado, conta com o apoio intelectual e moral de homens que mais tem se distinguido nas ciências, letras e artes. A U. P. interessa a todos os indivíduos que preconizam um ideal de felicidade universal, principalmente as classes trabalhadoras que, se compreenderem a alta importância desse maravilhoso projeto colherão os mais felizes resultados em benefício de sua cultura moral e do seu engrandecimento intelectual, ganhando assim forças para mais facilmente liberta-se da tirania iníqua que a oprime.

A educação proposta por aquela instituição não seria voltada para a "civilização" ou "regeneração moral" das classes trabalhadoras, mas sim para a "felicidade universal". Se a expressão representa um ideal extremamente vago, o termo "civilização" não era tão mais esclarecedor. O breve resumo sobre os fins da Universidade mostra que "a cultura moral e o engrandecimento intelectual" que ela facultaria à classe pretendiam ser uma fonte de força, ou em outras palavras, instrumento de uma luta para libertação dos oprimidos.

Além do chamado à inauguração da Universidade Popular, Força Nova convoca os leitores para a conferência que seria proferida pelo "camarada Erasmo Vieira, ilustre tribuno libertário, falará na sala da Sociedade Operária do Jardim Botânico, domingo, 31 do corrente, a uma hora da tarde, uma conferência da qual o tema será - Educação Social”. É fácil perceber a relevância da questão educacional para estes trabalhadores no momento em que se dispunham a debatê-lo em um domingo a tarde, pouco do que sobrava de sua jornada semanal de trabalho. Como já foi apontado anteriormente, não se tratava de "qualquer educação", ela ganha uma qualificação desde o título da conferência, seria "social". Propostas de educação para transformação social e libertação, protagonizadas pelas classes trabalhadoras não seriam anacrônicas para os fins do século XIX e início do XX.

Bastante atual é também a visão de educação veiculada pelo Panificador que não separa a instrução da vida cotidiana. Ela seria um direito, de acordo com J. M ${ }^{92} \ldots$ No artigo "Nossos Direitos", o padeiro reivindica além do "aumento de ordenado", alimento para o corpo, o 
desenvolvimento intelectual resultado do estudo e do "convívio da sociedade instruída e honesta", alimentos para o espírito. Mas para o estudo seria necessário "sossego" e "instantes em que o corpo [estivesse] descansado dos trabalhos manuais". No entanto, mais do que a instrução, a visão de educação dos padeiros comportava a valorização de seus saberes de experiência. É o que vemos na pequena apresentação do novo diretor do Panificador que assume após o "companheiro Pinho" ter sido nomeado secretário gerente da sociedade. Procurando apresentar-se de forma humilde, o diretor afirma: “... como todos vós sabeis; pois que eu não tenho tido outras escolas se não as no interior das casas em que trabalho; mas com o vosso valioso apoio espero poder corresponder se não com brilhantismo, pelo menos com consciência a confiança em mim depositada”. Ou seja, o interior das casas em que trabalhavam era a escola dos operários, tipo de formação afirmada com modéstia, mas com orgulho.

Nesse sentido, algumas associações de trabalhadores procuravam, sempre que possível, afirmar a importância dos saberes de experiência, principalmente aqueles adquiridos no exercício dos ofícios, como aponta o editorial de O Panificador (1 de janeiro de 1900), falando em nome da Sociedade Cosmopolita Protetora dos Empregados em Padaria. "Precisamos mostrar àqueles que nos humilham e sugam dia e noite nosso trabalho, o nosso suor, a custa de uns miseráveis mil réis, que não somos ignorantes, que compreendemos tão bem, ou, melhor que eles, os sentimentos que enobrecem o homem e o tornam útil à sociedade e à pátria. É preciso valorizar o nosso trabalho". Uma das grandes provas que as associações operárias se dispunham a dar, era do valor intelectual dos trabalhadores. O que se devia ao fato do discurso hegemônico desqualificar seus saberes e sua capacidade de pensar, em função da definição de uma sociedade dividida entre trabalho manual e trabalho intelectual, onde o primeiro era posto em condição inferior, motivo pelo qual os padeiros reclamavam ser preciso "valorizar nosso trabalho".

A Revolução (1881) também demonstra uma visão crítica de educação, a que teria recebido do governo com armas na mão, estaria longe de representar uma alternativa de pacificação social.

Porque não temos medo de lutar com os grandes somos exagerados. Para quem o cano da espingarda, o silvo de uma bala, o fio de uma espada, são coisas horrorosas, para os pusilânimes e covardes, nós somos loucos. Mas para aqueles que, como nós, foram educados pelo próprio governo empunhando uma espada pelo espaço de 12 anos, familiarizados com os estampidos dos canhões... para aqueles que não podem assistir impassíveis, alegres e satisfeitos, o roubo infame que os governos fazem ao povo, o aviltamento a que nos reduzem, o saque público de nossos direitos, nós não seremos exagerados.

Não teremos a louca intenção de levar nossa propaganda revolucionária até os monarquistas ferrenhos, até os cidadãos indiferentes e sem amor pátrio, até mesmo aos republicanos encasacados que tratam de si antes da pátria. (...) Para estes que no dia do nosso sacrifício ou da nossa vitória não bastará o compartimento mais interno dos palácios para esconderem-se, nós não 
fazemos propaganda, a nossa missão é somente com o povo, mas com o povo miúdo, com o zé-povinho a quem pertencemos e onde vivemos. (...) O povo, o verdadeiro povo, esse sabe perfeitamente que é necessário a Revolução!

O jornal trata da educação dada com armas na mão pelo próprio governo enquanto o pensamento hegemônico condena o uso da violência para mudança social e associa a educação à via pacífica de mudanças necessárias. Não utiliza o termo "educar" o povo, mas fazer propaganda no meio do "povo miúdo", do 'Zé-povinho" do qual afirma fazer parte. Estando entre um dos poucos jornais que não classifica o povo como "ignorante" e "apático", não se arvora no papel de educá-lo pois este já saberia perfeitamente o que era preciso saber - a necessidade da revolução. 


\section{Capítulo 4- Luta por escolarização: as classes populares reconhecem o papel da escola}

Trabalhando o sal é o amor e o suor que me sai

Vou viver cantando o dia tão quente que faz

Homem ver criança buscando conchinha no mar

Trabalho o dia inteiro pra vida de gente levar

Água vira sal lá na salina

Quem diminuiu a água do mar

Água enfrenta o sol lá na salina

Sol que vai queimando até queimar

Trabalhando o sal pra ver a mulher

se vestir

E ao chegar em casa encontrar

a família a sorrir

Filho vir da escola, problema maior é o de estudar

Que é pra não ter meu trabalho

E vida de gente levar

(Canção do sal, Milton Nascimento, 1966)

A Canção do Sal, de Milton Nascimento, com a qual abro o último capítulo, foi inspiração para concepção deste trabalho e, percebo agora, que é uma síntese dele. Se me apoio na noção fundamental de experiência com o auxílio da definição dada a ela por Thompson (1981), procuro vivenciá-la e promovê-la ao compor este texto, permitindo que nele transpareça sua marca. A música como parte de nossa experiência sensível, presente em nosso universo cultural, nos ajuda também a olhar a realidade passada e presente. Em dado momento, escutar Milton, evocou minha própria infância, a importância que minha mãe, mulher trabalhadora, de classe popular, via e fazia ver a meus irmãos e a mim, o quanto a escola seria necessária para "não termos o mesmo trabalho que ela", e "vida de gente levar". Orgulhosa do fruto de suas próprias mãos, nos deliciosos pratos que preparava, nas peças de tricô que tecia, o que ela desejava para nós, não era prescindirmos do trabalho, mas podermos, ascendendo socialmente por intermédio da instrução, resguardarmo-nos um pouco de sua exploração excessiva.

Essa experiência é comum a muitos sujeitos das classes trabalhadoras, sonhos compartilhados até hoje, e que agora percebo de outro ponto de vista, como professora de estudantes da educação básica em escolas públicas ${ }^{93}$. Desde quando e de que forma, homens e

93 Refiro-me às redes municipais e estadual do Rio de Janeiro. Cabe lembrar que o termo "escola pública" abriga realidades muito diversificadas. 
mulheres trabalhadoras empenharam-se na luta por escolarização para seus filhos? Já que a escola seria forma de acesso não só a saberes sociais, mas a títulos sociais e mesmo, em certos momentos a títulos políticos, como o título de eleitor, tratado no primeiro capítulo desta tese. Encontrei muito da canção de Milton nos abaixo-assinados de pais de família e chefes de família no Rio de Janeiro oitocentista. E um tanto ainda, nas dificuldades do trabalhador em proporcionar vestuário para sua família, inclusive o que permitisse a frequência dos filhos à escola, atestadas nos relatórios dos presidentes de província do Rio de Janeiro, como um dos motivos da baixa frequência às escolas públicas em freguesias rurais. Mas, sobretudo, é o sonho de legar aos filhos, ou à própria classe, uma vida melhor por meio da instrução, que espalha a canção do sal por todas as páginas desta tese.

Do ponto de vista mais estritamente acadêmico, este trabalho como um todo, e o presente capítulo, em particular, são tributários da perspectiva do grupo de pesquisa junto ao qual foi realizado, o Núcleo Interdisciplinar de Ensino e Pesquisa em História da Educação (NIEPHE) da Faculdade de Educação da USP quando procura:

(...) Ao dar ênfase ao exercício cotidiano dos sujeitos históricos, tomados nas relações que estabelecem com a sociedade e a história perceber como a escolarização elementar foi sendo (re)inventada no período pelos vários grupos sociais, expressando diferentes anseios e exibindo tensões sociais. [Perspectiva esta tributária da] virada antropológica permitiu colocar a ação dos sujeitos no centro da problemática de investigação. Nos termos de E. P. Thompson (1981, p. 188), ela emergiu sob a nomenclatura de experiência. (...) Gerada pela vida material e estruturada em termos de classe, a experiência expressava a vontade social. (...) Na lição de Certeau (1994, p. 93) , despontou sob a designação de "artes de fazer" ou "práticas". Traduzia a recusa do autor em perceber a cultura popular como ingênua, espontânea e infantil e o povo como passivo e disciplinado. (VIDAL \& BICCAS, p. 2125).

Partindo dessa inspiração, procuro, no primeiro momento, entender o processo de instalação e manutenção das escolas subvencionadas como parte da luta das classes populares por escolas, tanto na corte, quanto na província do Rio de Janeiro. Num segundo momento, diretamente relacionado ao primeiro, apresento o estudo da sua ação reivindicativa direta, por meio de abaixoassinados.

A relação entre classes populares e escola é tensa desde a criação dessa instituição. De maneira geral, a implantação da forma escolar foi um processo de lutas e adaptações, demandas e resistências. Discutindo sobre direito à educação e obrigatoriedade escolar, Baía Horta (1998) constata o paradoxo das leis educacionais que a constituem ao mesmo tempo como direito e como obrigação. A hipótese central desta tese indica, entretanto que a perspectiva do direito foi construída historicamente por conflitos e superação das relações de dádiva que envolviam o acesso do povo pobre à escola. 
No Império, o debate sobre a obrigatoriedade escolar não se dava pelo ponto de vista do direito do cidadão, mas sim do Estado em submeter a população à escolarização. Nesse contexto, a defesa da obrigatoriedade feita por intelectuais e legisladores foi apropriada, também, pela população em suas reivindicações por escolas e na legitimação das suas iniciativas de atendimento a seus filhos e a si.

O próprio Baía Horta esclarece que "Durante muito tempo, no Brasil, ao direito de educar por parte do Estado, correspondeu a obrigatoriedade escolar como imposição ao indivíduo. Só muito recentemente ao direito à educação por parte do indivíduo correspondeu a obrigatoriedade de oferecer a educação por parte do Estado" (BAÍA HORTA, 1998, p. 11). Na Constituição de 1824, a instrução primária era gratuita, mas não era definida como direito. A gratuidade foi reafirmada na lei de 15 de outubro de 1827, que determinava a criação de escolas de primeiras letras nas cidades, vilas e lugares mais populosos. O Ato Adicional de 1834 transferirá essa responsabilidade para as províncias.

A primeira província a estabelecer a obrigatoriedade escolar é Minas Gerais, em 1835, quando passou a determinar multas para os responsáveis dos menores que não frequentassem a escola e nem recebessem instrução. No Município neutro, o regulamento de 17 de fevereiro de 1854 estabelecia a instrução obrigatória para crianças a cima de sete anos com penalidades para seu descumprimento, porém, segundo Baía Horta (1998) as prescrições sobre o assunto fizeram-se "letra morta". Foi apenas com a Reforma de 1879 que o ensino se tornou obrigatório no raio de um quilômetro e meio da escola para meninos e um quilômetro para meninas. Multas de 20 a 100 mil réis seriam aplicadas aos pais que não mandassem seus filhos à escola.

A questão da obrigatoriedade suscitou muitos debates à época. De modo geral, ela era defendida como forma de garantir a educação do povo, porém relativizada em nome da falta de condições financeiras do Estado, da população, bem como da liberdade de ensino. Segundo Rui Barbosa (Apud. BAÍA HORTA, 1998, p. 14), em seu parecer de 1883: “Assim como a legislação escolar pressupõe em boa doutrina, que, aliás a prática, nem sempre tem observado, a gratuidade da escola sem a frequência imperativa representa uma instituição mutilada".

\section{1- A demanda popular por escolarização e as escolas subvencionadas}

Escolarizar a população, mesmo para aqueles legisladores e governantes defensores de seu caráter benéfico, de sua "missão civilizadora", demandava a construção de espaços adequados ao ensino, definição de tempos de aprendizagem, remuneração de pessoal, em suma, “ (...) a produção da singularidade da instituição escolar e da cultura que the é própria" (FARIA FILHO \& VIDAL, 
2000, p. 20). A documentação investigada até então permite afirmar que o financiamento estatal dessas práticas era um dos grandes entraves para sua difusão.

Foi assim que, no suprimento da escolarização, forma de prover a alfabetização, critério de cidadania política desde 1881, o Estado imperial priorizou os núcleos urbanos, áreas centrais mais populosas para instalação das escolas públicas. No caso da corte, as freguesias rurais foram preteridas e para suprir essa demanda que passou a aparecer, efetivamente, sob a forma de abaixoassinados de seus moradores, foi comum contar com a iniciativa particular de professores animados pelos moradores das localidades. Estes abriam suas aulas em comunidades pobres contando com a subvenção que o Estado passou a fornecer por alunos que não podiam compensar ao professor pelo ensino. Realidade próxima a que foi sintetizada por Faria Filho e Vidal quando apontam

(...) indícios de que a rede de escolarização doméstica, ou seja, do ensino e da aprendizagem da leitura, da escrita e do cálculo, mas, sobretudo daquela primeira, atendia um número de pessoas bem superior à rede pública estatal. Essas escolas, às vezes chamadas de particulares, outras vezes de domésticas, ao que tudo indica, superavam em número, até bem avançado o século XIX, àquelas escolas cujos professores mantinham um vínculo direto com o Estado. Em que espaço elas funcionavam? Grosso modo pode-se dizer que tais escolas utilizavam-se de espaços cedidos e organizados pelos pais das crianças e jovens aos quais os professores deveriam ensinar. Não raramente, ao lado dos filhos e/ou filhas dos contratantes vamos encontrar seus vizinhos e parentes. O pagamento do professor era de responsabilidade do chefe de família que o contratava, em geral um fazendeiro (FARIA FILHO \& VIDAL, 2000, p. 21).

As escolas subvencionadas possuem muitas das características marcadas no trecho citado, mas não podem ser consideradas escolas efetivamente particulares. Nas áreas afastadas dos núcleos urbanos, na corte e província do Rio de Janeiro elas podem ser vistas, a princípio, como formas de “coadjuvação" entre Estado e comunidades. Nos primeiros momentos em que os governos provincial e imperial passaram a subvencionar vagas para crianças pobres em escolas particulares, esta modalidade aparecia nos relatórios com a denominação de "escolas particulares subvencionadas". Havia, porém, casos em que todas as crianças de uma determinada localidade eram pobres e todas as vagas eram preenchidas no regime de subvenção, logo a nomenclatura dessas escolas passou a usar apenas o termo "subvencionadas" sem o termo particular. A caracterização dessa forma de atendimento ficará mais clara ao longo deste primeiro tópico do capítulo 4.

É possível encontrar no acervo do Arquivo Geral da Cidade do Rio de Janeiro (AGCRJ) volumes de códices sob o título "Escolas Subvencionadas" contendo diversos ofícios em que professores requeriam à Inspetoria de Instrução, solicitados pelos pais de alunos pobres e 
intermediados por delegados de instrução de suas freguesias, auxílio monetário para provimento de seu ordenado e material escolar.

É o caso da escola de meninas da freguesia da Lagoa, situada na Rua Boa Vista e dirigida por D. Cândida Barreiras, que atendia 10 alunas pobres, completamente analfabetas, subvencionada pelo governo. Ao afirmar "com satisfação prestarem-se [as meninas] a receber esse benefício e espero por outras, cujas famílias pedirão alguns dias de demora em arranjarem o vestuário, mesmo na simplicidade facultada" (Ofício do delegado de instrução primária e secundária da freguesia da Lagoa ao inspetor geral de instrução a corte, 1871) o delegado de instrução nos permite observar o grau de esforço despendido pelas classes populares no intuito de mandar seus filhos à escola, desde o momento que prescindem de seu trabalho, até a dificuldade para arranjar vestuário, mesmo simples, para que pudessem frequentar as aulas.

Essa mesma necessidade era suprida, na freguesia da Ilha do Governador, pela própria professora, D. Adelina Tatagiba que, segundo informa o delegado Germam Mendes Limoeiro, atendia diariamente entre 40 e 50 meninas, estando matriculadas 55 meninas e 3 meninos. “... além de todas receberem instrução gratuita, tem essa professora por diversas vezes empregado à subvenção em vestuário e calçado para que não deixem as discípulas de frequentar a escola, pois a exceção de 5, são todas filhas de pescadores e de libertos que foram escravos do Mosteiro de São Bento..." (Informe do delegado de instrução da Ilha do Governador, Germam Mendes Limoeiro à Inspetoria de Instrução Primária e Secundária da Corte, Barão de S. Félix sobre frequência ao curso da professora Adelina Tatagiba, 15 de julho de 1880).

Esse tipo de iniciativa organizada não só pelos professores, mas da qual, podemos afirmar, os pais/moradores das localidades participavam ativamente, fosse pedindo aos mestres que montassem aulas, ou pressionando o Estado pelo provimento de ordenado e material, era muitas vezes "o único recurso da localidade", caso do "lugar denominado Cascadura, freguesia de Inhaúma”, onde D. Paula Carolina dos Santos fornecia instrução primária gratuita a 32 meninas pobres.

A mesma professora também ensina diversos trabalhos de agulha, de modo que a sua escola tem sido de reconhecida utilidade para a população pobre existente na circunvizinhança do referido lugar onde não há nenhum outro estabelecimento de instrução, quer para instrução primária quer secundária, para o sexo feminino (Ofício do delegado de instrução de Inhaúma, João Guilherme Smith, ao Inspetor Geral de Instrução Primária e Secundária da Corte, Conselheiro Dr. José Bento da Cunha Figueiredo sobre subvenção à escola particular, 10 de dezembro de 1874).

Observando o requerimento de Luiz Gomes Azevedo ao delegado de instrução da freguesia 
de Jacarepaguá por informações sobre procedimento para pedido de subvenção, vemos o uso de termos veementes, e seu posicionamento como benevolente prestador de serviço humanitário, quando tratava ele de seu próprio meio de sustento.

Ilmo e Exmo Sr. Delegado da Instrução $1^{\mathrm{a}}$ e $2^{\mathrm{a}}$ de Jacarepaguá. Tendo sido rogado com insistência por diferentes vezes pelos moradores desta localidade para ensinar primeiras letras aos meninos que pela informação dos Sr. Inspetores de Quarteirão abaixo assinados V. Rma verificará que sobe ao número de trinta, por isso vejo-me obrigado a recorrer a V. Sra. Rma. e declarar que só por uma subvenção do Governo Imperial é que posso prestar esse relevante serviço à mocidade, porque esses meninos são filhos de pais pobres e faltos (sic.) de todos os recursos, como atestam os referidos Srs Inspetores de Quarteirão. Assim se digne V. Sra Rma ordenarme de que modo deve ser o meu procedimento (Requerimento de Luiz Gomes de Azevedo ao delegado de instrução da freguesia de Jacarepaguá de informações sobre procedimento para pedido de subvenção, 7 de janeiro de 1875).

Podemos interrogar o quanto temos aí de subterfúgios do professor para obter a verba governamental, mas não é disso que trata o presente capítulo e sim de um conjunto de moradores pobres mobilizado em torno da instrução, reivindicando-a frente ao Estado. Até porque a própria verba governamental não representava quantia “de encher os olhos”. Pelo contrário, há nos códices pesquisados, diversos ofícios solicitando aumento do valor das subvenções já que não seriam suficientes para pagar o aluguel da casa onde a escola estava instalada, material didático para os alunos, além do sustento do professor e sua família.

Outra reclamação constante dizia respeito ao atraso e irregularidade no pagamento das subvenções, como atesta a queixa movida pelo delegado da freguesia da Lagoa, José Teodoro da Silva Azambuja, em nome do curso noturno para adultos da Sociedade Propagadora da Instrução.

Realmente é de lastimar-se que essa Sociedade que tão bons serviços está prestando a essa freguesia e que luta com não pequenas dificuldades para preencher a honrosa tarefa de que se há incumbido e felizmente tem desempenhado à custa da perseverança e dedicação dos membros da sua diretoria encontre também dificuldades na cobrança regular do auxílio valioso com que a honrou o governo imperial (Ofício do delegado de instrução da Lagoa, José Theodoro da Silva Azambuja ao Inspetor Geral de Instrução Primária e Secundária da Corte, Conselheiro José Bento da Cunha Figueiredo sobre subvenção em atraso à curso noturno, 20 de outubro de 1874).

Era notório que o custo da subvenção de vagas ficava muito aquém do custo para abertura de escolas públicas. Este era, inclusive, um dos argumentos usados na requisição de verbas por particulares. É o que vemos expresso na defesa feita pelo Inspetor de Instrução, Barão de São Félix, 
ao ministro dos negócios do império a favor do pedido da professora Maria Brasil Silvado, da freguesia do Espírito Santo quando afirma:

Sua escola está colocada num ponto muito distante das aulas públicas e onde há muitas meninas pobres, e presta serviços que prestaria uma escola pública que naquele lugar seria conveniente criar se não fosse a facilidade de conseguir a mesma vantagem com menos dispêndio aproveitando o magistério da requerente... ( Ofício do Inspetor Geral de Instrução Primária e Secundária da Corte, B. de São Félix ao Ministro dos Negócios do Império, advogando a favor de subvenção pedida pela professora Maria Brasil Silvado para atender a meninas pobres em sua escola de meninas na Rua da Estrela $n^{\circ} 13$, no Rio Comprido, freguesia do Espírito Santo, 24 de janeiro de 1877).

Seja pela pressão da demanda popular, sem a qual não se estabeleceria a questão dos meios mais econômicos de instruir o povo das freguesias rurais, seja pela própria conveniência do Estado, o que vemos, segundo o delegado de Guaratiba é que:

(...) A não existirem essas escolas, a numerosa população dos bairros de $\mathrm{S}$. Clara, Mato Alto, Mojarça, Cantagalo e Cachamorra, deixaria de educar seus filhos. (...) Quanto a utilidade das escolas subvencionadas é tão manifesta nas freguesias rurais principalmente em Guaratiba que se não houvessem outras razões, bastaria confrontar-se a matrícula e frequência das três escolas públicas que é inferior a das escolas subvencionadas (Resposta do delegado de instrução de Guaratiba ao ofício da Inspetoria da Instrução Primária e Secundária da Corte, enviando-lhe a frequência das escolas subvencionadas da freguesia: escolas particulares de S. João e S. Marcelino e afirmando que são essas de muito proveito, 4 de novembro de 1877).

A confiar nesta contabilização, em que a frequência das escolas subvencionadas se mostra maior que das escolas públicas, considerando que as subvencionadas representavam forma de atendimento da demanda popular, parece que temos argumentos suficientes para acreditar em um papel ativo das classes populares na difusão da educação primária na corte, principalmente nas localidades mais pobres e distantes do centro do município.

A realidade dos povoados rurais da província do Rio de Janeiro aprofundava os problemas educacionais citados para a corte. Mais contraditório era o projeto civilizatório exposto nos relatórios de presidentes de província, nos quais a educação ocupava papel fundamental, sem que visse para si os correspondentes esforços estruturais e dotações orçamentárias. Ao analisar, desde o primeiro ao último relatório das autoridades máximas da província, encontramos em 1839, redigido por Paulino José Soares de Souza, membro da tríade Saquarema, o desenho do projeto de educação popular pautado pelo Estado Imperial. Tendo desenvolvido, no mesmo documento, um tópico sobre "segurança e prosperidade pública", aponta em seguida o papel da educação na prevenção de crimes. Era comum estabelecer uma ligação entre frequência de crimes e focos de 
desordem com o atraso da instrução. "Torna-se fácil perceber, neste ponto, que os saquaremas se impunham tarefa mais ampla do que simplesmente instruir no próprio momento em que eles se constituíam. Em seu relatório referente ao ano de 1839, Paulino já chamava atenção para a necessidade de também educar. (...) Educar tornava-se pois a ação por meio da qual cada um dos alunos deveria adquirir os princípios éticos e morais considerados fundamentais à convivência social” (MATTOS, 1994, p. 252).

Cabe notar os tipos de crimes destacados pelo presidente da província: homicídios e roubos, atribuídos, na maioria das vezes, aos escravos, e junto a estes, o crime da vadiagem. Ou seja, eram crimes, os atentados aos pilares da sociedade capitalista em desenvolvimento: o indivíduo, à propriedade e a produtividade do trabalho.

Não enumerei o atraso em que infelizmente ainda se acha a instrução primária e de que começa a sair, entre as causas que tornam mais frequente o cometimento de crimes. Estou, pois, muito convencido de que a instrução que se tira das nossas escolas primárias, isto é, o saber escrever, ler e contar, as vezes imperfeitamente, não pode suprir a educação e exercer grande influência sobre a moralidade. É mister pois distinguir a instrução da educação, que tiramos de tudo quanto nos rodeia, e das impressões que recebemos nos primeiros anos. Os bons costumes, segundo a expressão de um publicista consciencioso e ilustre, nascem da educação, somente a educação os cria e perpetua, porque é ela somente que verdadeiramente nos ensina nossos deveres e os reduz à prática. Na Inglaterra, na França e nos Estados Unidos tem-se reconhecido que não basta se estabelecer escolas, primárias para prevenir a desmoralização e diminuir o número dos crimes. A instrução é (servindo-me de alheia expressão) um instrumento do qual se pode fazer bom uso ou mau uso. É preciso, portanto, juntar a instrução primária a educação, e educar o povo, inspirar-lhe sentimento de religião e moral, melhorando-lhe assim pouco a pouco os costumes (Relatório do Presidente da Província do Rio de Janeiro, 1839).

De acordo com o projeto representado por Paulino não seria suficiente, ou mesmo, conveniente, apenas instruir o povo. Era necessário associar instrução e educação. Instruir consistia em ensinar a ler, escrever e contar. Educar seria moralizar de acordo com os valores da civilização ${ }^{94}$, leia-se: do Estado Imperial e da religião, leia-se: do catolicismo. Para se obter os

94 Em relatório da presidência da província, no ano de 1846, teríamos um emblema do que representava a "civilizar" para o Estado brasileiro. Segue citado trecho do tópico "Catequese e Civilização dos Î́ndios": "Por uma fatalidade inconcebível tem sido sempre infrutíferas todas as diligências e esforços empregados pelo governo para fazer aldear, civilizar, e propagar nessa Província a raça dos indígenas que ainda aqui e ali aparece e para lhes garantir as terras de seu patrimônio e os foros delas. Parece que esta raça está destinada a desaparecer diante da raça branca e a acabar de ceder a esta o resto das terras que primitivamente ocupavam a despeito mesmo das leis que a garantem e das providências desde muito adotadas pelo governo para chamar os índios a aldeamentos, porquanto ou seja pela natural indolência destes indivíduos, quase sempre mais dados ao uso de bebidas espirituosas do que pelo trabalho, ou pelo desvalimento que persegue sempre as raças conquistadas, ou em fim pela cobiça que também acompanha sempre a raça conquistadora, o certo é que desses mesmos aldeamentos em vez de crescer desaparecem constantemente essa raça e seu patrimônio vai sendo cada vez mais apossado e invadido se é que já não o está de todo, sem que o governo tenha podido embaraçá-lo, pois que em alguns lugares, os próprios índios tem, posto que 
instrumentos da instrução, “do[s] qua[is] se pode fazer bom ou mau uso", era preciso submeter-se, concordando ou não aos valores do Estado e da Igreja Católica. Jean Hébrad (2001, pp. 115 - 141), referindo-se à França entre os séculos XVI e XIX afirma que as necessidades básicas da vida urbana foram usadas pela Igreja Católica para levar o povo à escola onde encontrariam a satisfação destas necessidades e onde seriam catequizados. Depois, agências liberais e filantrópicas vão utilizar a mesma via para difundir o catecismo da ordem contra as revoltas e revoluções, visando a paz social, característica da modernidade. No mesmo sentido, Viñao Frago (1999, pp. 319-351) aponta as pressões em favor da escolarização e alfabetização da classe trabalhadora como fruto de motivações ideológicas conservadoras frente às ideias socialistas e uma cultura operária em gérmen e das necessidades de uma mão de obra com certa qualificação elementar.

Importa questionar até que ponto o conjunto da população atendida pela escola primária, estava disposta a aceitar esse conjunto de valores. Era muito comum, como atestam os próprios Relatórios de Presidentes de Província, que os pais tirassem os filhos das escolas após adquirem os primeiros rudimentos da leitura, escrita e cálculos, não os deixando permanecer por todo tempo estipulado pelas autoridades educacionais para sua formação. Anne Marie Chartier também aponta o descompasso entre a concepção de tempo de escola das famílias populares e das autoridades, e como esse tempo de escola variava em função da classe social que se escolarizava.

A entrada nas leituras "livres" era, assim, muito vigiada, e dependia dos treinos praticados ao longo do tempo. Essa entrada era sempre empurrada bem para além do ano durante o qual eram percorridas três divisões ou classes dos iniciantes. Essa lentidão percebida claramente por J. B. La Salle, não era para ele um defeito, ao contrário: como as famílias populares retiravam seus filhos da escola a partir do momento que em que os meninos aprendiam a ler, a produção gradual (em nove turmas) assegurava três anos de escolaridade, tempo mínimo em sua opinião para preparar bem uma comunhão e assegurar uma educação cristã durável. Quando a escola se dirigia à crianças melhor dotadas socialmente, ou escolarizadas muito cedo, cujos pais podiam permitir a instrução sem urgência, essa preocupação desaparecia, uma alfabetização curta, ou seja, rápida e mesmo fácil e divertida passava a ser uma vantagem e não mais um risco (CHARTIER, 2007, p.90 e 91).

Há indícios de que, tampouco todos os professores, se submetessem a tais autoridades, uma vez que a "grande questão continuava sendo a falta de uniformidade entre as escolas (...) [e] a falta de informações por parte das escolas particulares" (Relatório do Presidente de Província o Conselheiro Paulino José Soares de Sousa, 1839).

A importância atribuída ao projeto de educação do povo por meio da instituição escolar 
esbarrava muitas vezes no fator financiamento. Esta postura foi explicada por Mattos (1994) ao apontar que "não se reivindicava para o governo do Estado tanto um dever, e sim um monopólio de uma direção também neste campo particular: 'resta ainda tornar uniforme o sistema de ensino das atuais escolas e dar-lhes mais conveniente direção, estabelecendo meio de o fazer e de fiscalizar se os professores cumprem como devem seus deveres" (MATTOS, 1994, p. 252). Os governos tanto das províncias como da corte procuravam sempre uma fórmula de incremento da educação com a maior economia para os cofres públicos. O presidente da província do Rio de Janeiro, Souza França, em seu relatório de 1841, afirma que, mesmo melhoradas as condições financeiras da província, não seria possível nem conveniente prover todos os materiais solicitados por professores de primeiras letras.

(...) pois não somos nós uma nação de proletários, cujos pais não possam suprir à seus filhos nas Escolas de Primeiras Letras, o diário fornecimento que se faz mister para aprender a ler e escrever, como sempre se praticou: o primeiro dever da educação literária dos filhos pertence aos pais; o impulso geral dela no país, levando-se as localidades mais distantes os Mestres públicos que os ensinem, para difusão das luzes dos conhecimentos humanos, é quanto me parece necessário para encher as vistas políticas do Legislador Filantropo.

De acordo com essa lógica, escravos e trabalhadores livres pobres são desconsiderados como parte da nação. Ao considerar que impulsionar a educação no país, significava levar mestres públicos às localidades mais distantes, esquecia das necessidades básicas de qualquer educando para frequentar uma escola: vestimenta, calçado, material escolar, além mesmo da possibilidade de se alimentar e dispor de tempo para isso. As crianças e adultos trabalhadores não possuíam tais condições. Ao reconhecer tais carências, o próprio Estado estimulará, sem investir diretamente recursos, associações filantrópicas que forneciam subsídios materiais para crianças pobres frequentarem escolas. A educação voltada à estes sujeitos estaria no âmbito da filantropia e não do direito. Porém, ao demandar e buscar diferentes meios de suprirem as necessidades de sua instrução, os proletários estariam afirmando a si como membros da nação e a instrução como seu direito.

Ainda sob a bandeira da economia e do bom gasto do dinheiro público justificava-se o estabelecimento de regimes educacionais diferenciados de acordo com o público e regiões atendidas. O presidente de província, Aureliano de Souza e Oliveira Coutinho atribuía aos pais de meninos pobres, em toda província, o desperdício de gastos com professores que “(...) tão caro fica, embora tenham a obrigação de ensinar tudo quanto a lei ordena, não tem a quem ensinar na maior parte da província se não as primeiras noções de escrita, leitura e contabilidade e de fazer decorar os alunos o catecismo de Montpellier..." (Relatório do Presidente da Província do Rio de Janeiro, 
1846). Estes pais, assim que entendiam poder os filhos ajudarem-nos no trabalho da lavoura, no tráfego da pescaria, ou na taberna, os retiravam da escola, sem preocupação com o término dos estudos. Junta-se a esse fator o de que os pais pobres, por vezes, não podiam prover vestuário ou calçado aos filhos para mandarem-nos para escola. Nesse ponto, o relator aproveita a oportunidade para desqualificar o comportamento dos pais citando casos em que "por um mal entendido orgulho que eles se apresentem vestidos inferiormente aos filhos de pais mais abastados, preferem vê-los crescer na ignorância...".

Diante da realidade de um professor caro e mal aproveitado surge, pela primeira vez nos relatórios dos presidentes de província do Rio de Janeiro, a proposta de subvenção de vagas em escolas particulares, dispensando a escola pública em algumas localidades, mas não usa ainda o termo "escola subvencionada".

$\mathrm{Eu}$ criaria nos lugares menos populosos, escolas onde somente se ensinasse a ler, escrever, contar, e os princípios da religião, exigindo dos professores para tais escolas, além de moralidade, somente as habilitações precisas para bem desempenhar esse magistério, e impondo-lhes o dever de guiar como pai em todos os domingos à missa os seus discípulos... (...) exigiria dos mestres particulares as mesmas habilitações e exames que fossem exigidos para o magistério público e conquanto os pais preferissem esses e o governo reconhecesse que eles cumpriam melhor as funções do magistério acabaria a escola pública e daria uma gratificação ao mestre particular com a obrigação de ensinar ele também e gratuitamente os meninos pobres (Relatório do presidente da Província do Rio de Janeiro, o senador Aureliano de Souza e Oliveira Coutinho, 1846) .

O que o governante preconizava era uma educação mais restrita para os lugares menos populosos, freguesias rurais, onde, em muitos casos, a totalidade dos meninos e meninas que apareciam frente ao professor para receberem o ensino, eram pobres. A estes se ofereceria uma educação muito mais voltada para moralizar e catequizar do que para instruir. Mas, já na data deste relatório (1846), encontramos apelo de pais de crianças a solicitar do governo, meios de escolarização de seus filhos. Era o caso dos habitantes de São Domingos que "(...) têm pedido instantaneamente ao governo a criação de uma escola ali do sexo feminino, pois que não é possível que suas filhas venham de tão longe a escola dessa cidade..." (Relatório do presidente da Província do Rio de Janeiro, o senador Aureliano de Souza e Oliveira Coutinho, 1846). Seguindo a leitura do mesmo documento observamos que não só de São Domingos e sim "De vários outros pontos da Província se tem pedido a criação de escolas: ser-vos-ão presentes os ofícios em que são reclamadas" (Relatório do presidente da Província do Rio de Janeiro, o senador Aureliano de Souza e Oliveira Coutinho, 1846). A posição de descaso com a instrução atribuída pela presidência da província aos pais de família não parece se confirmar diante de tais pedido, bem como da forma de 
pedir pela abertura de escola "instantaneamente", numa postura ativa em definir o tempo para seu atendimento.

A subvenção foi o meio econômico do Estado atender a demanda popular por instrução. Vemos evoluir no tempo, tomada a data do citado relatório, em 1846, a correlação de forças estado e sociedade. Neste primeiro momento, a subvenção foi apenas cogitada, a partir da década de setenta, aproximadamente, encontramos um grande volume de abaixo-assinados requerendo escola, como veremos a seguir. Ao mesmo tempo, as escolas subvencionadas passavam a ser uma política melhor definida, com recursos destinados, compondo os quadros estatísticos da província e da corte.

Elas eram, porém, regimes educacionais diferenciados que tinham a ver com a concepção de uma sociedade estanque, dividida em classes inferiores, superiores e intermediárias, as quais corresponderiam graus de instrução hierarquizados, o que pode ser percebido no relatório de Aureliano de Souza e Oliveira Coutinho, presidente da província do Rio de Janeiro em 1848.

É essa instrução comum, essa identidade de hábitos intelectuais e morais, como bem diz um dos homens mais vistos nessas matérias, o Sr. Cousin, que constituem a unidade e a nacionalidade. À igualdade civil, à igualdade dos direitos e deveres consagrados no pacto fundamental deve-se acrescentar a da instrução elementar. E como em todos os países há uma classe numerosa da população que não podendo, ou não desejando destinarse às profissões sábias, tem entretanto a necessidade de uma cultura mais extensa e mais variada que a classe inferior propriamente dita, a dos operários e homens do campo, nasce daí, naturalmente o segundo grau de instrução primária, que ficando inferior quanto aos estudos clássicos e científicos ao dos colégios e Liceus, versa mais sobre conhecimentos de uma utilidade geral.

A instrução comum que associada à identidade de hábitos intelectuais e morais comuns constituiria a unidade da nacionalidade, só era comum dentro de cada um dos níveis estanques. A ideia de igualdade de direitos e deveres, a igualdade civil entre livres, convivia com a desigualdade de classes expressa no termo: "a classe inferior propriamente dita, a classe dos operários e homens do campo". Especificamente sobre a população do campo, já se desenhava, além das relações de classe, o domínio dos centros urbanos. A educação participava da produção deste domínio, ao passo que era também seu produto, considerada pelas autoridades provinciais como prioridade de "centros em que se introduzem e derramam mais facilmente os elementos da civilização que tem, depois, de estender-se em suas irradiações aos lugares menos habitados, em toda parte as capitais e as cidades importantes exercem influência sobre os outros pontos do país, transmitindo-lhes o impulso do seu exemplo" (Relatório do Presidente da Província do Rio de Janeiro, Conselheiro Antonio Nicolau Tolentino, 1858). 
No entender de José Ricardo de Sá Rego, vice presidente da província do Rio de Janeiro, em 1861, era nas escolas que se formava o cidadão. Por isso, "a província não tem poupado sacrifícios" para "o derramamento das luzes e progresso da instrução". O que embaraçaria este progresso? Maus professores, dificuldades na inspeção das aulas pelas dificuldades de transporte e comunicação, as distâncias que separavam as escolas e o descaso dos pais de família. "Imprevidentes e descuidosos, muitos não compreendem que o dever de educar os filhos não é menos sagrado do que o de nutri-los e vesti-los" (Relatório do Presidente da Província do Rio de Janeiro, Dr. José Ricardo de Sá Rego, 1861). Como não fossem aproveitados os "sacrifícios da província" e dificultado o interesse de professores abrirem aulas em povoados distantes, a solução pensada pelas autoridades foi o relaxamento das regras para abertura de escolas particulares nessas localidades.

Os próprios interesses da instrução exigem que nas cidades e outras grandes povoações, assim como na proximidade das escolas públicas se não franqueie o magistério particular a quantos o quiserem exercer, sem ter antes provado sua proficiência. Será, porém vantajosamente aplicada essa restrição às pequenas escolas de nossos sertões? O exame de habilitação assusta a homens e aterra a senhoras que apenas sabem mediocremente ler e escrever: a viagem à cidade ou à vila próxima é incômoda e custosa, a autoridade insta pelas provas de capacidade, o professor fecha a sua escola, fonte única em que 15 ou 20 crianças podiam beber algumas noções de instrução primária, alguns princípios de religião, fecha-se também a escola da professora, mais tarde as mulheres do lugar serão estranhas à costura, e incapazes de ler, ainda soletrando, um livro de orações. De que proveito são pois para a cultura intelectual e moral dessa classe da população as exigências da lei? Não seria mais conveniente longe das grandes povoações e das escolas públicas conceder certo grau de liberdade ao ensino primário particular, sujeitando-o unicamente à inspeção da autoridade no que se refere à religião e à moral (Relatório do Presidente da Província do Rio de Janeiro, Dr. José Ricardo de Sá Rego, 1861).

O vice-presidente da província defendia, dessa forma, em seu relatório, uma dualidade de regras para funcionamento das escolas particulares: uma para localidades populosas e outra para o sertão. Em nem um dos dois casos o governo provincial abriria mão da habilitação religiosa e moral. No restante, os alunos do sertão poderiam ter como mestres homens e senhoras que apenas soubessem "mediocremente ler e escrever" porque esta já seria a realidade daquelas localidades. Outra ideia muito difundida nos relatórios presidenciais era de que, melhor seria uma má educação, do que educação nenhuma. É preciso lembrar a diferença existente entre o fato do mestre particular ter apenas o mínimo a oferecer e o fato do Estado oficializar aquela condição, por ser qualquer outra solução mais dispendiosa.

No relatório da presidência da província de 1862, vemos acrescentar-se um dado novo na explicação para a pouca frequência às escolas de freguesias rurais. O relator enumera quatro fatores 
para compreensão do pequeno número de alunos e pouca assiduidade destes em algumas escolas: "As causas desse inconveniente são quanto a mim: 1- incúria dos pais; 2- necessidade que tem alguns pais pobres do serviço de seus filhos; 3- achar-se a população em algumas freguesias, muito disseminada e não haver boas vias de comunicação; 4- acharem-se algumas escolas mal colocadas". As três primeiras causas já estavam presentes na maioria dos relatórios anteriores, mas na quarta, a autoridade provincial reconhece uma inadequação na implantação de escolas, fato de sua responsabilidade: a escola vazia em uma dada localidade poderia ser bem frequentada em outra mais conveniente para a população.

A má localização das escolas era motivo de frequentes reclamações dos pais de alunos. Ressoam, ainda, no mesmo relatório, outras queixas como a falta de adiantamento de crianças já a quatro ou cinco anos na escola, respondida pelo vice-presidente como sendo resultado da falta de assiduidade dos alunos. Os castigos físicos citados em seguida poderiam representar mais motivos para retirada dos filhos da escola, ou mesmo pela abstenção da matrícula. Tentando suavizar a prática dos castigos, o relator, porém, "[era] de opinião que eles não devem ser absolutamente abolidos" (Relatório do Presidente da Província do Rio de Janeiro, 1862).

A pouca frequência ocasionou nos anos de 1863 e 1864 um amplo movimento de fechamento de escolas com base na autorização dada à presidência pelo artigo 12 da lei 1271 de 1863. Porém, nas palavras do Conselheiro João Crispiano Soares, presidente da província do Rio de Janeiro em 1864, a educação seria condição indispensável para vida da nação.

(...) o povo deve ser bastante esclarecido para compreender as leis eternas do dever e os ditames da razão e guardá-las no exercício de sua liberdade. Derramar a instrução, cultivar o coração e a inteligência do povo é um dever sagrado do governo como representante de todos os interesses morais da sociedade. A educação do povo é uma condição indispensável para fortalecer a estabilidade das instituições e garantir a ordem da sociedade a que somos todos atraídos por uma tendência natural e uma vocação divina (Relatório do Presidente da Província do Rio de Janeiro, 1864).

O povo necessitava de esclarecimento para compreender as leis do dever e ditames da razão. Mas, quem estabelecia os deveres e quem ditava a razão? A liberdade estaria condicionada por essas leis e por essa razão que o governo entendia deter. Daí viria seu "dever sagrado" de "derramar a instrução e cultivar o coração e a inteligência do povo", uma vez que se colocava na posição de "representante de todos os interesses morais da sociedade". Porém, de acordo com Mattos (2004), sabemos que a elite imperial, no caso da província do Rio de Janeiro, os chamados Saquaremas, afirmava representar interesses gerais, quando estava, de fato, a serviço dos interesses de um grupo específico - os cafeicultores escravocratas do Vale do Paraíba, que se apresentavam de forma bem 
articulada e expansionista. Era nesse sentido que a educação do povo significava para o governo "a condição indispensável para fortalecer a estabilidade das instituições e garantir a ordem da sociedade".

Dessa forma, João Crispiano Soares não desconhecia a necessidade de cada freguesia ter uma escola para meninos e outra para meninas. Mas, esbarrando nas primeiras dificuldades, logo ficava claro que o tal povo não era um termo conhecido por sua universalidade. Não havia um "ser povo" comum a todo homem ou mulher nascido na província. Logo, "o povo" de algumas localidades veria suas escolas públicas suspensas por falta de frequência. Mas, na necessidade de garantir a "estabilidade das instituições" e a "ordem da sociedade" surgia como alternativa a remuneração de professores particulares que atendessem certo número de meninos pobres. Uma curiosidade nos vem em mente: se a matrícula na escola pública era escassa, por que haveria demanda para um professor particular? Não era pequeno o número de freguesias onde não havia escolas públicas, como podemos ver no quadro a baixo. 


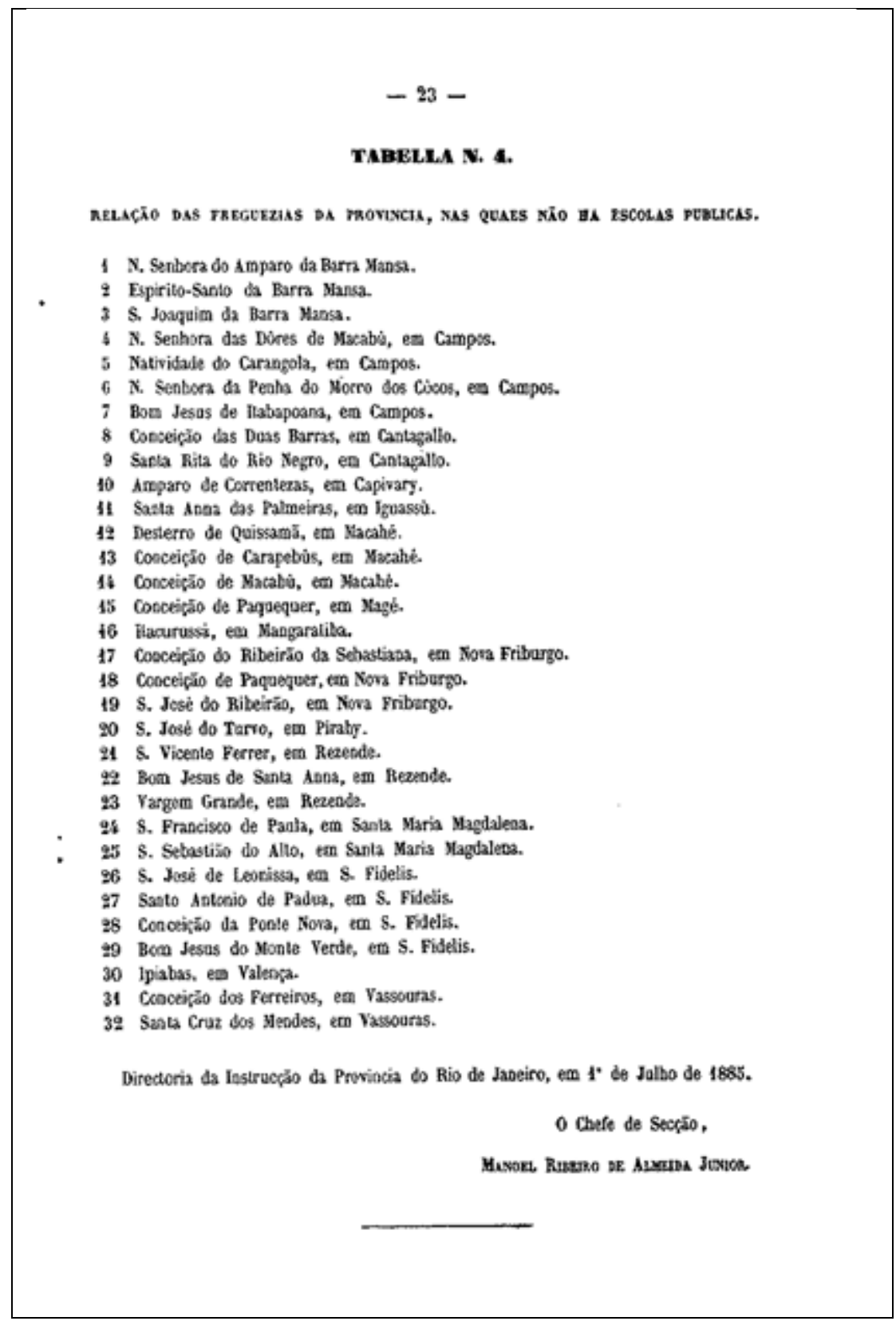

Figura 5- Relação das Freguesias do Rio de Janeiro onde não há escolas públicas. Imagem retirada do Relatório do Presidente de Província do Rio de Janeiro para o ano de 1885.

O problema da "disseminação da população" continuou se interpondo, por muito tempo, "como um dos maiores embaraços com que luta a administração para promover a difusão das luzes" (Relatório do Presidente da Província do Rio de Janeiro, Desembargador Diogo Teixeira de Macedo, 1869). E, em 1869, temos o termo analfabetismo, em uma de suas primeiras aparições nos relatórios presidenciais, dramatizando “(...) a desgraça para aquele que o suporta, e quando nossa Constituição garante a instrução primária gratuita a todos os cidadãos, não é para nós somente um dever combatê-lo, é quase um crime não lançar mão de todos os meios de evitá-lo" (Relatório do Presidente da Província do Rio de Janeiro, Desembargador Diogo Teixeira de Macedo, 1869). No mesmo relatório encontramos, ainda, um dos primeiros usos do termo subvenções, para se referir a 
alternativa às escolas públicas nas freguesias rurais. Em suas considerações gerais, o diretor de instrução aponta que há indubitável progresso quanto ao número de escolas e quanto ao número de alunos, porém lentamente e ainda sem ser proporcional à população da província. As causas para essa desproporção e lentidão eram, segundo o diretor de instrução, Thomaz Gomes dos Santos, algumas evidentes e outras obscuras. Ele pretendia relatar ambas, e indicava já ter tomado algumas medidas embora fosse taxado de "inoportuno".

Entre a primeira ordem de fatores estava a disseminação (dispersão) da população rural. Não se apresentavam professores que se dispusessem a viver em "lugares baldos de todos os recursos", algumas escolas eram fechadas por falta de alunos, outras por baixa frequência. As autoridades provinciais julgavam, por tais motivos, não se justificar o dispêndio que a província tinha com elas. "Para atenuar as consequências de uma tal distribuição da população em muitas localidades da província, só dois meios encontro: dar-se maiores facilidades à propagação do ensino particular primário, e coadjuvar com subvenções suas escolas quando colocadas a certa distância das públicas e admitirem número determinado de meninos a cujos pais faltem os meios de retribuir o ensino" (Relatório do Presidente da Província do Rio de Janeiro, Desembargador Diogo Teixeira de Macedo, 1869).

Outras causas entre as que foram assinaladas por Thomaz Gomes dos Santos foram: a vacina; a falta de condições das escolas por sua má colocação ou por suas más instalações; a interrupção das aulas por motivos como licenças aos professores ou dificuldades de sua substituição. Vale a pena seguir de perto os argumentos do diretor, em um dos poucos registros onde os pais das classes populares não são considerados os grandes culpados pela falta de instrução dos filhos. Talvez, por isso mesmo, o diretor de instrução tenha sido taxado de "inoportuno" perante a presidência e a assembleia provincial.

$\mathrm{O}$ art. 74 do regulamento dispõe que não sejam admitidos às escolas públicas os meninos não vacinados. (...) Peço respeitosamente permissão a V. Ex. Para acrescentar que nem sempre são os pais os culpados. Poucos são os municípios da província providos atualmente de médicos vacinadores, e não me consta que naqueles que os têm, percorram estes empregados as freguesias rurais, anunciem sua chegada, demorem-se nela os dias precisos, e se haja organizado, enfim, um serviço regular. Sendo esta a situação, é evidente que o preservativo só pode ser empregado nas cidades e vilas que possuem vacinadores ativos, assíduos e que tenham consciência do seu dever. Não me cabe Exm. Sr. indagar e apontar meios que tornem efetiva a aplicação da vacina, não posso, porém, dispensar-me de declarar que os que hoje se empregam são pela maior parte ineficazes, e que um deles, o da negação de matrícula nas escolas públicas aos meninos não vacinados, sem de forma alguma atenuar um mal, produz outro grave (Relatório do Presidente da Província do Rio de Janeiro, Desembargador Diogo Teixeira de Macedo, 1869). 
Este relatório é especialmente importante no âmbito desta tese, pois representa um documento produzido no âmbito do poder de Estado, os próprios poderes provinciais são responsabilizados pela baixa frequência e lenta disseminação da instrução. A experiência vivida por Thomaz Gomes dos Santos no exercício de sua função, já que experiência não é um privilégio de classes populares e diretores de instrução, além de "alguns intelectuais atuantes sofrem, eles próprios, experiências" (THOMPSON, 1881, p. 17), por um momento suplanta as ideologias de elites governantes sobre um povo ignorante, cego, desinteressado pela instrução. Após o problema da vacina, o diretor de instrução aponta o problema das más condições das casas escolares, impróprias para seu uso. Tópico no qual insinua, ainda, um possível estratagema de transferência de renda dos cofres provinciais para proprietários de imóveis locais. $\mathrm{O}$ aluguel das casas para escolas parecia ser um bom negócio para seus proprietários.

A casa destinada para escola pode não convir a esse fim em dois casos: $1^{\circ}$, sendo mal situada; $2^{\circ}$, não tendo os cômodos necessários: em qualquer dessas condições é a frequência mínima. Uma escola deve ser colocada no centro da maior povoação, e sem que pântanos e rios embarguem seu acesso aos moradores das localidades não muito distantes. (...) Quando se trata de criar novas escolas, as autoridades locais consultadas declaram que há ali excelentes casas de diminuto aluguel, criadas, porém, elas, não é raro que apareçam grandes dificuldades: todas as casas do lugar estão ocupadas, só uma pode servir, seu dono, porém, exige elevado aluguel...

Por fim, o diretor aponta as constantes suspensões do ensino por licença dos professores das escolas públicas como fator de desânimo e abandono dos estudos.

Não raras são as supressões do ensino em nossas escolas e muito especialmente nas freguesias rurais ocasionadas já por licenças que os professores alcançam dos respectivos inspetores paroquiais ou do governo provincial, já por moléstias atestadas por facultativos... É evidente que uma escola, embora muito frequentada, enquanto for nela o ensino regularmente ministrado, perderá grande número de alunos se as interrupções se repetirem, ou se prolongarem...

O relato marcado pela experiência do diretor de instrução nos leva a supor que a negligência à educação popular como um direito público acabava por fazer com que o pouco recurso a ela destinado fosse apropriado para fins e interesses particulares.

A partir de 1871, vemos a postura das autoridades provinciais se tornar mais ativa na promoção da instrução popular, data deste ano a primeira lei de obrigatoriedade escolar para a província fluminense. Aqueles anos trariam novos dados para a vida social e política nacional: a Lei 
do Ventre Livre, o censo de 1872, as movimentações para reforma eleitoral. Segundo Martinez,

A emergência de discursos e de uma legislação direcionada a reformar o ensino público na Corte imperial estava diretamente relacionada a questões políticas e sociais daquele contexto. A emancipação impulsionada pelo gabinete Rio Branco e a consequente aprovação da lei de 28 de setembro de 1871, conhecida como Lei do Ventre Livre, também colocaram o problema da instrução popular em evidência - incluindo agora no interior dessa expressão, os ex-escravos. No texto da lei, as crianças libertas deveriam ser educadas pelos senhores de suas mães até a idade de 8 anos, quando poderiam ser entregues ao Estado que lhes enviaria a estabelecimentos de educação primária e aprendizagem de ofícios. Em caso de continuarem com os senhores os libertos prestariam serviços até 21 anos. A lei trouxe à tona uma série de problemas, entre eles, que destino seria dado às crianças "ingênuas" e de que maneira poderiam ser educadas e disciplinadas.(SCHUELER, 1997, p. 31).

A política provincial para educação deveria acompanhar o processo de reformas. Incentivo aos cursos noturnos de instrução para trabalhadores, às escolas dominicais e, principalmente, o aumento do número de subvenções às crianças pobres em escolas particulares. Para tanto, solicitavam o auxílio de associações beneficentes que atuavam desde o oferecimento de aulas até provimento de vestuário à crianças pobres, viabilizando sua frequência às escolas.

Segundo Josino do Nascimento Silva, presidente da província do Rio de Janeiro em 1872, além de diretor de instrução por muito tempo na mesma província, as subvenções teriam satisfeito uma grande necessidade, só por meio delas teria sido possível cumprir "com menos sacrifício dos cofres públicos", a dívida do Estado de vulgarização dos primeiros conhecimentos num contexto de população esparsa. Assim poderia ser cumprido o preceito constitucional de manutenção de uma escola para ambos os sexos em cada núcleo urbano, ainda que a instrução tivesse "que ser dada não como a desejamos, mas como for possível ministrá-la..." (Relatório do Presidente da Província do Rio de Janeiro, 1872). Relativização das ideias do mesmo Josino que, em relatório anterior, defendera o ensino público, criticando as subvenções por estimularem disputas de interesses locais.

O Conselho Diretor da Instrução Pública parece preferir o ensino particular ao ensino público. Não adoto semelhante ideia porque a instrução primária gratuita é obrigação do governo, que deve ter sempre escolas públicas em toda parte, embora permitindo a liberdade do ensino particular. Este ensino não deve ser subvencionado porque a subvenção é motivo para ma luta de interesses locais contra as escolas públicas, segundo já tenho observado. (Relatório do Presidente da Província do Rio de Janeiro, Josino do Nascimento Silva, 1870).

O valor das subvenções era considerado baixo - $2 \$ 000$ por aluno, só podendo o professor admitir até quinze alunos subvencionados, número que mais tarde passara para vinte. Com esse 
valor, o professor teria que pagar a casa, mobília, livros, etc. O relatório presidencial de 1872 apresenta o caso do professor da escola subvencionada de Aldeia Velha, "frequentada por mais de 30 alunos, fechou-a por lhe não ser possível mantê-la com a quantia recebida para esse fim”. Mesmo já sendo essa uma medida econômica para o ensino, vemos que a verba provincial para as subvenções não era grande. Em seu relatório o desembargador Manoel José de Freitas Travassos, presidente de província em 1873, atesta que: "Não tendo sido suficiente a verba consignada no orçamento vigente para custear durante o ano as escolas subvencionadas existentes em número de 30 resolveu V. Ex. que não se subvencionasse nenhuma outra, continuando entretanto seu trabalho as que funcionam atualmente até que a assembleia desse as providências que reclama a continuação e extensão de ensino de tão grande proveito e tão pouco gravoso aos cofres públicos".

A publicação do censo de 1872 alarmou as autoridades imperiais. Os números indicavam que numa população de 456.850 almas, mais de dois terços eram analfabetos. "78.882 meninos de ambos os sexos e de idade de 6 a 15 anos existiam desde então, e destes só frequentavam as escolas 19.959, os outros 58.923 estavam fora da civilização! São algarismos esmagadores que não encontram compensação na favorável posição relativa em que está a província" (Relatório do Presidente da Província do Rio de Janeiro, 1875). Estes dados atestavam a necessidade de mais escolas, mas que tipo de escolas? O mesmo Travassos, em 1874, divide-se entre a defesa da escola pública, com a crítica da instabilidade das escolas subvencionadas que ficariam na dependência da vontade dos professores por um lado e a conveniência das subvenções por outro. Estas últimas eram sempre reafirmadas como o meio de oferecer instrução nas áreas menos povoadas, que pela conclusão do relator, provavelmente, as áreas que abrigavam os 58.923 meninos e meninas encontradas fora das escolas pelo recenseamento.

Estudando as tabelas dos números de matrículas e frequência em escolas públicas e particulares apresentadas a cada relatório, percebemos que a partir do ano de 1874 o número de escolas subvencionadas passa a ser especificado nas planilhas do governo, a escola subvencionada torna-se uma categoria de escolas, sinal da importância que vinham assumindo. A terminologia também muda de "subvenção em escolas particulares" para "escolas subvencionadas". É muito comum que elas fossem mantidas quase totalmente pelas verbas governamentais em localidades que praticamente todos os alunos eram pobres e não podiam retribuir os professores.

O movimento de aumento do número de escolas subvencionadas não encontrou par no desenvolvimento de escolas públicas, tendo sido, de acordo com o mesmo relatório, suprimido o ensino em várias delas por baixa frequência. Esta supressão gerou duas reações: a representação de pais de família, requisitando a reabertura de escolas e "prometendo que no futuro demonstrariam o apresso que faltava a elas..." (Relatório do Presidente da Província do Rio de Janeiro, 1875); e a 
inciativa de vestir os filhos de pais pobres que não os podiam mandar às escolas, dando-lhes, assim, condições de frequência. "Foi na supressão do ensino nas escolas de diminuta frequência que adquiriu força e expansão o sentimento de caridade que por mais de uma vez eu procurara desenvolver para obviar a desculpa que muitos encontravam fácil na indigência dos pais que não mandavam os filhos à escola por não poderem vesti-los decentemente" (Relatório do Presidente da Província do Rio de Janeiro, 1875). Esta atitude, classificada como caritativa pelo presidente da província, poderia significar uma rede de solidariedade em torno da instrução dos filhos de cidadãos em uma determinada localidade. Ao mesmo tempo, o que era entendido como "desculpa" para não mandar os filhos para escola podia ser uma carência real e impeditiva. É interessante notar que o mesmo tipo de "desculpa" era usado pelo governo provincial para justificar as quedas estatísticas na escolarização. O relatório de presidentes de província para o ano de 1879, afirma que aquele teria sido um ano “(...) calamitoso... sol ardentíssimo, chuvas torrenciais e sobretudo as moléstias que grassaram em todas as povoações da província...".

Ainda sobre as pretensas "desculpas" dadas pelos pais para não mandarem os filhos à escola, encontramos no relatório do visconde de Prados, de 1878, a seguinte consideração:

(...) em meu conceito o mais implacável adversário que encontram o patriotismo do legislador, a energia do administrador e o zelo de seus delegados é a indiferença desesperadora com que a família vê e trata a escola. Desejam-na, querem mais de uma na proximidade do domicílio: mas, tendo-a, deixam-na no mais ingrato abandono, contentando-se apenas, quando o fazem, de dar o nome dos filhos à matrícula reservando-se o direito de não os mandar à aula. Não há lei, não há ação que tenha força, nas nossas circunstâncias, contra a cegueira dos pais, filha dos hábitos velhos e que só com o tempo e muito lentamente se irão desarraigando. E o erro, a culpa depara com milhares de escusas, que simulam justificação aos próprios que as alegam. São transações com a consciência. Ora é a estação que corre mal e por prejudicar a saúde do menino, ora são as enfermidades que grassam na localidade e de que é necessário preservá-lo; aqui é chagado o tempo da colheita e são necessários os serviços dos filhos, ali é a pobreza que não permite dar-lhes as roupas e os calçados necessários para frequentarem a escola; uns não os mandam porque o professor os desagrada, ou não ensina e traz os discípulos em atraso, outros porque nunca souberam ler e escrever, assim têm vivido granjeando os meios de subsistência e não reconhecem a necessidade da instrução primária, querem os filhos para homens de trabalho e não para doutores.

Havia, entretanto, um conjunto de instituições de caridade criadas, efetivamente, por elites para fins de promoção da instrução. Atitude nem um pouco desinteressada se considerarmos os agradecimentos da presidência da província feitos aos cidadãos beneméritos, em que o relator cita o pensamento do Bispo de Orleans, o Sr. Dupanloup: "Digo por toda parte, devemos estar prontos e armados. A arma é a instrução e a moral cristã. Sem isso senhores, e eu quisera dizer também, ouvi- 
me, operários, ainda mais interessados que nós nesse futuro, sem a instrução e sem a moral cristã, dentro de dez anos os operários instruídos serão descontentes, e os ignorantes, indigentes" (Relatório do Presidente da Província do Rio de Janeiro, 1875). É ainda a "caridade" nada desinteressada que o mesmo relatório registra a respeito da educação dos ingênuos, numa torpe cena de paternalismo. Trata-se do asilo criado em Valença pelo comendador José Gonçalves de Moares.

Houve tempo em que o comendador Moraes pensou que lhe era mais cômodo e conforme os seus interesses entregar ao governo os ingênuos nascidos de suas escravas. Refletindo, porém, reconheceu que estava em perfeito engano, e que o verdadeiro interesse do lavrador é conservar esses meninos sob seu patrocínio, educando-lhes e dando-lhes a precisa instrução para que sejam no futuro a base sólida dos estabelecimentos agrícolas, se não os diretores e donos de situações pequenas fundadas em terrenos arrendados ou aforados aos proprietários de grandes fazendas com quem poderão ainda estipular outros contratos de vantagem comum. Daí o pensamento da fazenda modelo. Daí e esta consideração é ainda mais apreciável, a amizade dos escravos para o senhor, que assim se preocupa da sorte de tantas crianças que pareciam votadas ao mais duro abandono longe de seus pais ${ }^{95}$. Passei pela fazenda desse cidadão denominada Braço Grande e vi correrem para ele as crianças, a mando das mães que lhes diziam - vai tomar benção a padrinho. - O comendador José Gonçalves de Moraes tem apresentado na pia Batismal grande parte das crianças filhas de suas escravas, nascidas posteriormente à lei que decretou a liberdade do ventre (Relatório do Presidente da Província do Rio de Janeiro, 1875) .

A proposta educacional do século XIX, tanto a que provinha do Estado imperial, como das elites filantrópicas, teve caráter autoritário, de imposição de uma determinada forma de civilização. É recorrente na história da instrução popular o problema: ela seria uma necessidade ou uma ameaça para a manutenção da ordem? Essa é uma questão legítima que, a posteriori, poderíamos responder sem optar por nenhuma das duas alternativas, ou pelas duas: dependendo de sua apropriação a instrução poderia servir a um ou outro fim, uma vez que ela não é um terreno totalmente autônomo da vida social. Para o estabelecimento do império da lei, a instrução seria fundamental no entender dos intelectuais. Havia, entretanto, limites para a generalização da instrução. Como nem todos os homens estavam destinados ao trabalho intelectual, a instrução não deveria interromper o tempo de trabalho. Mas, por outro lado, as elites consideravam que a liberdade sem educação era perigosa. As escolas se constituíam em formas de controlar o tempo da infância e da juventude, principalmente para impedir o ócio e a vadiagem. Grande parte da ação educacional das elites do XIX estava pautada na crença de que um povo ignorante tem mais tendências para a revolta, sendo manobrado por agitadores. "Nesse sentido, contrariamente ao que pregam nossos militantes de agora, a educação não [era] entendida como fator de emancipação política, mas de subserviência" (FARIA 
FILHO, 2003, p. 178).

Caráter diferente teve a medida dos moradores da freguesia de Neves, em Macaé, que diante da constante alegação da falta de recursos provinciais decidiram se reunir e comprar uma casa que doaram à província para que ali fosse instalada uma escola pública. Não se identifica nesta situação um benemérito, mas a ação organizada de um grupo de cidadãos que, de certa forma, forçou os poderes provinciais a fornecer-lhes instrução. "O oferecimento que aceitei foi feito pelos cidadãos Luiz Sardemberg, João de Oliveira Prates e Querino Pereira Sodré, como representantes de todos que haviam concorrido para a compra. A casa está incorporada aos próprios provinciais e parece-me inquestionável o direito que têm os doadores à criação da escola para que tanto concorreram" (Relatório do Presidente de Província do Rio de Janeiro, 1877).

A iniciativa reduzira, o que o mesmo relatório do ano de 1877, feito pelo vice-presidente da província, Dr. Francisco Antonio de Souza, considerava “despesas extraordinárias” exigidas pela instalação das escolas públicas. Os encargos com as escolas públicas "seriam maiores que as subvencionas e ainda no futuro dão ocasião a jubilações”. Seria, dessa maneira, nem tanto a falta de interesse do povo por educação, mas a própria incapacidade do governo prover meios de educação para toda a população, a principal barreira ao funcionamento da lei de obrigatoriedade escolar. Cai por terra o discurso das autoridades de que a lei não emplacava por resistência das classes populares.

O interesse e a busca popular por escola aparecem pelas brechas dos próprios documentos oficiais, no caso os relatórios de presidentes de província, que tentavam defender a tese do descaso dos pais com a educação dos filhos. As representações por reabertura de escolas, a ação organizada dos moradores de Macaé, ou mesmo a influência dos alunos da escola noturna de Niterói, capital da província, em seu currículo, nos atestam que estes sujeitos sabiam o que queriam da educação e, talvez, que educação queriam.

Há nos alunos desta aula, desejo de aprender, que é secundado pelos esforços do professor, e espero que no fim deste ano haja ali exames que demonstrem o aproveitamento. Informou-me o professor que teve de ceder aos pedidos de alguns de seus alunos os quais pretendem dar de cor lições de história do Brasil, e de outros que desejam adquirir noções de geografia. Não pude deixar de aprovar o procedimento do professor, recomendandolhe, todavia que não prescindisse do ensino das matérias obrigatórias, exercitando-os em trabalhos de redação dos documentos, que são mais comuns na prática da vida e nas regras e operações da aritmética aplicadas aos usos ordinários (Relatório do Presidente da Província do Rio de Janeiro, 1878).

O sentido atribuído por estes alunos às escolas noturnas não era, necessariamente, o mesmo a elas atribuído pelas autoridades imperiais ou pelas elites filantrópicas. A luta por acesso à escola 
oficial se pautava, entre outros, em alguns dos motivos apontados por E. P. Thompson, em Educação e Experiência, seu único texto que trata especificamente do tema educação. Para o autor inglês, "A aprovação do sucesso educacional é assinalada de uma centena de modos: sucesso traz recompensas financeiras, um estilo de vida profissional, prestígio social. Ela se apoia numa apologia completa da modernização, necessidade tecnológica, igualdade de oportunidades" (THOMPSON, 2002, p. 43). Entretanto, a fonte citada nos leva a perceber um interesse desses alunos trabalhadores, público da escola noturna, por conhecimentos que não eram necessariamente “aplicados aos usos ordinários”. Nas próprias palavras do relator, um “desejo de aprender".

Para Silva (2000), em seu trabalho sobre as primeiras décadas dos oitocentos, as classes populares em geral, não valorizavam a escola, mas tampouco toda a elite a valorizava, entretanto, foi esta que tratou de assegurar o monopólio desse saber instruído. Os sujeitos de classes populares que valorizavam a escola, o faziam por quê? A autora cita o caso da parda, no início do século XIX, que requer instrução para os filhos, para estes não se tornassem feitores ou trabalhadores de enxada. Seu pedido é negado, por considerar o juiz que pardos devem mesmo trabalhar naqueles ofícios.

O “desejo de aprender”, de melhorar de vida, que os fazia buscar uma instrução, ainda que errante (THOMPSON, 2002), seguia, já nas últimas décadas do século, ao lado da determinação da redução do número de analfabetos motivada por abstrações como "o empenho de todos os brasileiros que por qualquer forma entendem com os negócios do país”. Diminuir o número de analfabetos, mesmo que por meio de uma instrução "tosca", era a proposta de João Marcelino de Souza Gonzaga que em 1880 relata:

Conheço a nossa população agrícola e prezo-me de pertencer a essa classe, que é a base larga em que assenta a prosperidade do país. O fazendeiro a pedido e a instâncias da câmara municipal ou de alguns de seus vereadores, não se recusará a mandar construir uma casa rústica em terras de sua fazenda para aí instalar-se a escola para meninos e meninas, filhos de seus empregados, agregados e aderentes, que residam em suas terras ou circunvizinhanças e de provê-los de alguns bancos e mesas toscas. Como não é necessário serem os mestres dessas escolas habilitados por escolas normais, nem se lhes exigirá que exibam provas de conhecimentos literários, bastando que saibam regularmente ler e escrever e contar, as câmaras poderão contratá-los por salários diminutos em relação aos ordenados e gratificações dos professores das escolas provinciais (Relatório do Presidente de Província do Rio de Janeiro, 1880).

Tamanha pressa em dar instrução elementar que acometia, ao menos na retórica, as autoridades provinciais, tinha a ver com as reformas que se processavam em âmbito nacional. O mesmo relatório citará medidas liberais adotadas na educação primária inglesa, inspiração para o Brasil no momento em que logo seria votada a reforma eleitoral.

Diz M. B., em um relatório dirigido recentemente ao ministro de instrução 
da França, a respeito da instrução primária na Inglaterra, de que li alguns extratos, que em 1868, votada a reforma eleitoral, os liberais ingleses não pouparam esforços para multiplicar as escolas e dar ao maior número das classes populares a instrução elementar. Estamos em presença da reforma eleitoral que, se não está ainda votada, amanhã ou depois será lei do Estado, e pesa sobre todos o dever imperioso de habilitar os cidadãos presentes e futuros para o bom exercício do direito de votar.

Cabe questionar, quais os cidadãos teriam o "direito de votar", já que, mesmo instituindo-se o critério de alfabetização restritivo ao voto, não se aboliu o critério de renda. Cabe pensar ainda, que tipo de habilitação vinha sendo promovida, considerando a prática do governo imperial legar em larga medida à particulares a promoção da educação para as classes populares, condescendente com um tipo de instrução "tosca", como exemplificado a cima. Após tanto exortar as disposições caritativas em educação, Souza Gonzaga não se animava a pedir à assembleia provincial, fundos para instalação de novas escolas. "Não me animo a pedir fundos para a instalação de novas escolas. Se a assembleia provincial em sua sabedoria e patriotismo entender que novos focos de instrução se deva estabelecer na província, eu preferiria as escolas subvencionadas que são menos dispendiosas e podem ser autorizadas nos lugares menos populosos..." (Relatório do Presidente de Província do Rio de Janeiro, 1880).

A própria lei que, desde 1876, tornava obrigatório o ensino primário nas cidades e povoações da província, sem ser extensivo às freguesias rurais, não era acreditada pelos presidentes de província. A lei provincial de $\mathrm{n}^{\mathrm{o}}$. 1.571 de 23 de outubro de 1871 foi a primeira a decretar a obrigação de ensino. A lei do orçamento de 1872 determinou (consignou) verba de 20:000\$000 para as despesas necessárias com a obrigatoriedade, disposição que não mais se repetiu nos orçamentos subsequentes. A lei de 1876 prescreveu as regras para o ensino obrigatório, as primeiras seriam o alistamento de meninos de um e outro sexo em idade escolar. Porém, na lei do orçamento não se destinou recursos para as despesas necessárias com o processo de execução da norma. No entendimento de Josino do Nascimento e Silva, diretor de instrução do Rio de Janeiro em 1881, as circunstâncias da província impediam, naquele momento, a execução da obrigatoriedade.

Penso que nas circunstâncias atuais da província o ensino obrigatório não poderá ser estabelecido, que outras necessidades mais urgentes relativas à instrução primária cuja satisfação não deve ser adiada, exigem esforços do tesouro provincial, que por enquanto os meios indiretos serão suficientes para difusão da instrução, que convém quanto antes cuidar da melhor distribuição das escolas e fixá-las de modo tal que não fique dependente do favor ou do ódio.

Diante da condição assumida, tanto das finanças da província, quanto do excessivo trabalho e pobreza da população, algumas medidas são pensadas para que o Estado obtivesse um mínimo de 
controle aos hábitos e saberes do povo necessário ao seu governo. Era o caso da divisão da escola primária em três níveis. A primeira classe já deveria prover: leitura, escrita, contagem e princípios de moral religiosa, tendo em vista que grande parte dos alunos abandonavam cedo a escola. O diretor de instrução chama, porém, atenção, para os perigos dessa medida, proposta pela comissão nomeada para desenvolver um programa das matérias para o ensino primário, tanto obrigatório como facultativo das escolas públicas, subvencionadas, aulas noturnas e dominicais (Relatório do Presidente da Província do Rio de Janeiro, Martinho Álvares da Silva Campos, 1881). "Não dissimularei, entretanto, o perigo que dessa divisão e sistema pode resultar e chamo para esse ponto a mais cuidadosa atenção da comissão. É muito usual que os pais dos escolares, fazendo-se de juízes das habilitações destes, os retirem da escola antes de obterem a aprovação final e declaração de estarem prontos. É hábito prejudicialíssimo aos professores, às escolas e à instrução popular”.

O tratamento irônico dado à atitude dos que se faziam de "juízes das habilitações" dos filhos, quando para isso "não teriam competência", procura encobrir a real interferência destes sujeitos na escolarização de seus filhos e no processo de escolarização em geral. É o que podemos observar caso encaremos o fato das crianças serem tiradas da escola nos primeiros anos, não pelo prisma do simples descaso, mas do cálculo acerca dos saberes necessário a serem adquiridos na escola, considerando o seu contexto de vida, bem como do cálculo dos ônus e benefícios daquela frequência.

Frequência que era, a julgar pelos relatórios presidenciais, dificultada não só por questões materiais e de valores das famílias populares, ou problemas de acesso aos locais das aulas, mas também por questões internas à política de escolarização adotada. $\mathrm{O}$ diretor de instrução, Josino Nascimento, critica, em 1883, o amesquinhamento da fórmula adotada pelas escolas primárias, de somente ensinar a ler, escrever e contar. Mesmo este ensino não possuía a necessária regularidade. Vemos um constante movimento de abertura e fechamento de escolas. Mas, contra os encerramentos das aulas, o relatório presidencial de 1885 nos dá notícias do levantamento "de clamores de todos os pontos da província".

Em obediência ao preceito legal, seria suspenso o ensino em 106 escolas destinadas ao sexo masculino e 85 ao outro. Eram 189 professores em disponibilidade ativa, que não seria fácil de empregar, vencendo ordenado enquanto não lhes fossem designadas escolas; era a remoção de móveis de umas para outras localidades da província, cujos prejuízos são conhecidos; era a necessidade de fornecer móveis a muitas escolas novamente instaladas e para as quais não se pudessem ser remetidas as mobílias existentes, ou não conviesse a mudança; era sobretudo o clamor que se levantaria de todos os cantos da província e que encontraria muitos advogados e protetores armados com os interesses da instrução pública garantida aos brasileiros pela Constituição Política do Império. 
Uma população que o Dr. Antonio da Rocha Fernandes Leitão, presidente de província em 1887, caracterizava como "ávida de instrução e educação" em comparação com o público das evening-schools dos Estados Unidos. Também no Brasil as escolas noturnas seriam um grande auxílio para "arrancar o povo da ociosidade, fazendo com que o operário e o lavrador, em dias e horas que não lhes impeça o trabalho, tratem de cultivar a sua inteligência, preparando-se para outros misteres da vida social e política" (Relatório do Presidente da Província do Rio de Janeiro, 1885). Recurso para "moralizar os adultos das classes operárias, que constituem a maioria da população". Falava-se de instruir e moralizar o povo e, como povo, especificava as classes operárias, os lavradores e os ingênuos. O declínio do sistema escravista acabava por destacar as classes trabalhadoras como preocupação dos governos, tanto em seu projeto econômico de disciplinarização do trabalhador livre, quanto politicamente, num momento em que esses sujeitos já se apresentavam de forma ativa e em vias de organização, tema abordado nos capítulos anteriores em que foi tratado o processo de educar-se das classes trabalhadoras por meio das suas associações de ofício, auxílio mútuo e resistência, bem como por meio de sua imprensa periódica.

O mesmo relatório apresenta, entretanto, o tipo de escola que seria dispensada às classes populares em geral e, especialmente, aos trabalhadores de freguesias rurais. Tece uma profunda crítica ao fato das escolas subvencionadas serem preferidas pelo governo em lugar das escolas públicas. Apesar de sua conveniência para "auxiliar" as escolas públicas o documento reconhece que "não é que a escola pelo lado pedagógico ofereça as necessárias garantias para o progresso e desenvolvimento da instrução pública. Não, certamente. Sendo tão deficientes as habilitações dos pretendentes à subvenção, só com uma consideração é lícito contar com elas: o pouco e mal que nelas aprendem os alunos é preferível à ignorância absoluta" (Relatório do Presidente da Província do Rio de Janeiro, 1885). E segue afirmando que "Quer ser professor subvencionado quem não pode sujeitar-se a um exame para professor público". E ainda:

No relatório do ano passado mencionei as causas principais que concorrem para que estas escolas não tenham produzido os resultados que delas se esperavam, a saber: falta de habilitação dos professores e falta de inspeção eficaz. Com raríssimas exceções, os professores subvencionados são pouco menos ignorantes que os próprios alunos; (...) Quanto às casas em que elas funcionam, em geral, não são boas, mas não é possível exigir dos professores que as tenham em melhores condições, porque não as há na localidade, ou porque não podem pagar maior aluguel com o pequeno auxílio que lhes concede a província. Contudo, algumas são péssimas.

Pelo que respeita ao material escolar, consiste, de ordinário de quatro ou cinco bancos e uma ou duas mesas. Nenhuma tem tábua preta para exercícios de aritmética. De uma escola diz o inspetor geral: "A casa é um pardieiro, a mobília consta de uma mesa, um tamborete e três bancos". De outra: "O material do ensino é péssimo; a casa é uma das piores que tenho visto" (Relatório do Presidente da Província do Rio de Janeiro, 1885). 
Nessas condições, a educação, geralmente defendida por intelectuais e elites governantes como meio de promover transformações políticas e sociais acabava por frustrar seus intentos. Nas considerações tecidas por José Bento de Araújo sobre a abolição da escravidão, podemos interpretar o discurso, sempre repetido, sobre o despreparo do povo e correlativa necessidade de instrução, não como preocupação progressista de melhorar as formas de participação social daqueles sujeitos e os destinos da sociedade em que estavam inseridos, mas como um meio de vetar ou adiar transformações sociais e políticas em defesa do status quo. Em narrativa emocionada o relator afirma que,

A luz da liberdade espargiu os seus clarões. É mister que ao lado dela (...) se levante o farol da instrução guiando as inteligências pelo caminho do dever, afastando da vontade as inspirações inoportunas que, postas em prática, podem dar em resultado o prejuízo da comunhão dos interesses brasileiros. De que nos servem quebrar os grilhões que manietavam os pulsos de tantos desgraçados? De que serve-lhes abrirem-se-lhes de par em par as portas da vida civil, se os conservamos esmagados sob o peso omnioso da ignorância, que no dizer de Edmond About, não é se não, uma das faces da miséria? A liberdade só, por si, basta ao homem? Não, responde Bernave do alto da tribuna da França revolucionária, não basta querer ser livre, é preciso saber sê-lo.

Ao discutir a cidadania dos libertos, Chalhoub afirma que eles não eram considerados preparados para a vida em sociedade. Na concepção das elites dirigentes "Os libertos traziam em si os vícios de seu estado anterior, não tinham a ambição de fazer o bem e obter um trabalho honesto, e não eram "civilizados" o suficiente para se tornarem cidadãos plenos em poucos meses. Era necessário, portanto, evitar que os libertos comprometessem a ordem e para isso havia de reprimir seus vícios. Esses vícios seriam vencidos através da educação” (CHALHOUB, 2001, p. 68).

Podemos extrair das concepções apresentadas no relatório do presidente de província e no quadro oferecido por Chaloub (2001) a mensagem que a instrução detida pelo povo parece nunca ser suficiente para habilitá-lo a usar sua liberdade. A instrução continuaria lhe faltando, como constantemente escutamos dizer, até hoje. No senso comum, "o povo é ignorante e não sabe votar", drama que perpassaria a história. Voltamos, de fato, a um dos problemas fundadores de nosso sistema político e de nosso sistema de ensino - a ligação direta feita entre grau de instrução e capacidade política. Dentro desta lógica nunca será suficiente a instrução definida como necessária ao povo, logo sempre faltar-lhe-á a razão. Ao fim e ao cabo, as ações políticas do povo, principalmente dos trabalhadores pobres, são sempre desqualificadas como irracionais. Quando ressaltamos a existência e procuramos entender o processo do educar-se das classes trabalhadoras por meio de suas experiências, incluímos aí um "aprendizado da política" que não passava 
obrigatoriamente pela escola, mas se dava em suas formas associativas, em sua produção cultural e mesmo em suas lutas por escolarização que, em si, também eram pedagógicas ${ }^{96}$.

\section{2- A reivindicação popular: abaixo-assinados solicitando escolas}

Foi a ação reivindicativa por escolas, levada a frente por sujeitos das classes populares, que possibilitou o provimento de instrução a diferentes povoações da província do Rio de Janeiro e da corte, desde, pelo menos, a segunda metade do século XIX. A reivindicação que, naquele momento, se efetivava por meio de abaixo-assinados pela abertura, manutenção ou reabertura de escolas é o assunto das últimas páginas. O trabalho com os textos dos abaixo-assinados que expunham tais solicitações nos permitiu conhecer aspectos da ação popular por educação. Sujeitos representados na documentação oficial como refratários ao ensino, envoltos nas "trevas da ignorância", desinteressados, ou desconhecedores da importância da educação de seus filhos, aparecem criticando o estado das escolas e procurando influenciar o processo de escolarização. Usando tom de súplica característica da interlocução com as autoridades imperiais o que os "moradores" e "chefes de família" faziam era exigir um direito constitucional.

A instrução que deveria ser, para alguns deles, uma estratégia de conquistas e ascensão individual, tornou-se um processo coletivo. Tomemos o raciocínio de Sidney Chalhoub (2007) ao estudar os processos de liberdade de escravos por compra de alforrias e por via judicial. $\mathrm{O}$ autor mostra como, não só revoltas e fugas em massa para quilombos, constituíam-se em lutas coletivas. Além do caráter de exemplo desses processos, das garantias em direitos costumeiros ou escritos em lei que eles lograram estabelecer, redes de solidariedade eram formadas em torno das compras de alforria e da manutenção da vida daqueles homens e mulheres depois de libertos. Possibilidades ampliadas após lei de 1871, que facilitava a indivíduos, ou setores da sociedade civil prestarem ajuda, ou solidariedade aos escravos na conquista da liberdade. "Ao proteger o pecúlio do escravo, garantindo-lhe também o direito de receber 'doações, legados e heranças', e ao dar-lhe o direito à alforria por autocompra à revelia da vontade senhorial, a lei de 28 de setembro de 1871 criara novas possibilidades para que os cativos e seus aliados, libertos e outros, se organizassem coletivamente para a compra de alforrias" (CHALHOUB, 2007, p. 224).

O que importa ressaltar é a subversão operada pela população escrava na lógica da compra de alforrias e dos processos judiciais, estes que deviam ser mecanismos individuais de acesso à

96 Ver Arroyo ( 2003). 
liberdade, acabaram tornando-se estratégias de luta coletiva contra a escravidão. Transpondo o mesmo raciocínio para o caso da instrução, vemos a subversão de um mecanismo de ascensão social individual que se torna uma bandeira de luta das classes populares. Disposição constitucional desde 1824, porém, na prática, ministrada ao povo como dádiva do Estado e, principalmente, de elites filantrópicas, a instrução vai, paulatinamente, se tornando fator aglutinador de comunidades em uma luta coletiva pelo direito a educação.

O teor dessa luta e a capacidade de interferência das classes populares nas políticas educacionais não se resumiam a requerer escolas. Pais de família, chefes de família, moradores de povoações, procuravam qualificar o tipo de professor que desejavam. No abaixo-assinado dirigido ao presidente de província do Rio de Janeiro, em 30 de junho de 1879 por dezesseis homens, moradores da povoação do Rodeio, vemos o protesto por um problema bastante comum à época, principalmente em freguesias mais distantes dos centros e de mais difícil acesso - o abandono pelo professor da cadeira que ocupava. Eles reclamavam da indiferença à educação de seus filhos naquela escola já abandonada a cinco meses. Usavam táticas discursivas, naquele caso, uma postura de zelo pelos interesses do governo que estaria "despendendo sem nenhum resultado". E, por fim, especificam o tipo de professor a quem pretendiam confiar a instrução de seus filhos: "esperamos ser atendidos e favorecidos com a presença de um professor que preencha as condições de seu cargo e não faça dele o uso de uma mera ocupação jornaleira" ${ }^{\text {97. }}$.

Nesse sentido, encontramos uma série de abaixo-assinados que requeriam a manutenção de determinados professores públicos. Em 28 de março de 1874, os habitantes da freguesia de Nossa Senhora da Conceição da Ponte Nova, no Município de São Fidelis, "suplicavam mui respeitosamente" ao presidente da província a manutenção do professor Leopoldino Honorato Lopes, "predileto do povo", naquela cadeira. Alegavam que "O professor Leopoldino Honorato Lopes reúne a ilustração, o bom método e a paciência de ensinar, é um modelo de virtudes e como tal venerado por todos desta terra. Sua retirada é uma grande calamidade para todos os pais que desejam a ilustração e moralidade de seus filhos porque jamais poderão encontrar tão abalizado preceptor" ${ }^{\prime 98}$. O documento era assinado por quarenta e cinco homens: dez fazendeiros (alguns com má caligrafia, pouco segura), nove negociantes, dois professores (um deles grafou o nome de sua profissão com “ç”), o vigário, o subdelegado, um juiz de paz e eleitor, um retratista, um lavrador (de caligrafia insegura), um escrivão da subdelegacia, e outros que não indicam ocupação. Os mesmos suplicantes enviaram pedido, também na forma de abaixo-assinado, ao professor, para que se

97 Abaixo-assinado dirigido ao Presidente da Província do Rio de Janeiro, 1879. Fundo Presidentes de Província do Arquivo Público do Estado do Rio de Janeiro.

98 Abaixo-assinado ao Presidente da Província do Rio de Janeiro, 1874. Fundo Presidentes de Província do Arquivo Público do Estado do Rio de Janeiro. 
mantivesse na escola.

Ao tratar da luta de homens e mulheres negros e pardos pela instrução de seus filhos, Adriana Paulo da Silva (2002) nos permite observar a interferência daqueles sujeitos na escolha do professor. A autora estuda o caso da requisição de permissão para funcionamento da escola de Pretextato dos Passos. Escola primária particular que atendia a "pretos e pardos". Foi fundada em 1853 e funcionou legalmente até, no mínimo, 1873. Pretextato pedia a dispensa de provas necessárias para abrir a escola. Alega timidez para não prestar os exames e justifica seu intento por pedidos dos pais dos meninos pretos e pardos, impedidos, pelo racismo, de frequentarem as escolas da corte, onde eram discriminados. Aqueles pais e mães entendiam que não seria possível, nem desejável um processo educativo num ambiente racista. O pedido é aceito por Euzébio de Queirós, inspetor de instrução primária da corte, sobre o que a autora questiona se teria sido um ato de segregação do inspetor, ou uma alternativa para a lei de obrigatoriedade frente a interdição de pretos e pardos nas escolas públicas.

Da mesma forma que os pais de alunos podiam requerer, via abaixo-assinado, a permanência de um professor, também acontecia de pedirem a mudança do mestre. Possuíam poder de pressão, pois retirados os filhos da escola, esta poderia ser fechada caso não houvesse uma frequência mínima. É do que trata a petição de 15 de julho de 1874 feita por oito homens e mulheres que criticavam o pouco zelo do professor público em função de suas outras ocupações com o colégio particular que dirigia. Assim se expressam:

Nós, abaixo-assinados, declaramos que retiramos nossos filhos do colégio público dessa cidade por vermos que eles nada aproveitavam aí, visto o pouco zelo e aplicação do respectivo professor e mais depressa tomamos essa deliberação por estarmos convencidos de que no ano próximo vindouro ficarão nossos filhos em completo abandono passando o mesmo professor público a dirigir colégio particular com cujos alunos irá ocupar-se exclusivamente em prejuízo do ensino público ${ }^{99}$.

Outro caso semelhante era o dos moradores da freguesia do Curato, termo de Barra Mansa, que em 24 de outubro de 1873 solicitaram da autoridade provincial a demissão ou remoção da professora pública Henriqueta da Silveira. Constam ali catorze assinaturas: um inspetor do distrito, três negociantes, sete lavradores, outros que não declararam ocupação. Os motivos do pedido são citados pelos abaixo-assinados:

As razões que os abaixo assinados têm para isso são as seguintes. A professora dorme até as 10 horas, até então as alunas cuidam de tudo, menos de estudar, ficam inteiramente sem direção. Levantando-se às 10 horas

99 Abaixo-assinado dirigido ao Presidente da Província do Rio de Janeiro, 1874. Fundo Presidentes de Província do Arquivo Público do Estado do Rio de Janeiro. 
apenas aparece na aula para logo depois retirar-se a fim de almoçar ao meio dia, entretanto que as alunas comparecem às 9 horas e retiram-se às 2 da tarde, mas nada aprendem. Apesar de ser professora a muitos anos, ainda não deu a uma só aluna proveito (?). Além disso tem em casa uma irmã que apesar de solteira tem filhos com um irmão do marido da própria professora, mas desgraçadamente há quem a proteja, pelo que os abaixo-assinados são forçados a apelas para V. Exa ${ }^{100}$.

Em 27 de junho de 1876 podemos detectar outro documento, na mesma linha dos anteriores, contra a remoção do professor público João Francisco Pires Junior e sua esposa, D. Leopoldina Camila da Silva Barata Pires. Os moradores da freguesia Bemposta, município de Paraíba afirmam que aqueles professores eram zelosos e cumpridores dos deveres e que as famílias estavam satisfeitas e agora estão preocupados com educação dos filhos por não conhecerem os que o substituíram. O diretor de instrução justifica que teve informações de autoridades incontestáveis para propor a remoção para Bom Jardim, pois na freguesia Bemposta havia poucos alunos e pouco aproveitamento dos que ali estavam. O professor, por seu turno, explicou a pouca frequência pelas chuvas e maus caminhos. Em seu apoio foram dadas 84 assinaturas, algumas delas a rogo.

Nem sempre desentendimentos ou apoio entre pais e professores se prendiam a "questões estritamente pedagógicas”. Nos pedidos por não fechamento de escolas na freguesia de São José da Boa Morte, em 7 de junho de 1875, diversos cidadãos, moradores no lugar denominado Subaio, procuravam explicar ao presidente da província os motivos da pouca frequência à escola que além dos grandes temporais e da licença de três meses dada "por esta presidência" ao professor, acresciase “... a circunstância de estar o atual professor indisposto com várias pessoas do lugar, o que até certo ponto impede a concorrência à escola. É pois de supor que de hora em diante a matrícula crescerá na proporção do ano passado, visto como tendo sido removido esse funcionário cessará este último motivo"101.

Entretanto, as indisposições locais podiam derivar da própria prática do professor em sala de aula. É o caso de José Francisco Roza Junior, que atraiu a antipatia dos residentes do segundo distrito de São João da Barra "em razão de mau trato em palavras e castigos rigorosos tiveram que retiraram-se a ponto que ficou sem um só aluno". Retirar os filhos da escola seria uma forma de controle dos pais contra tais excessos. Vejamos o texto completo do abaixo-assinado que contou com quarenta e cinco assinaturas, oito das quais a rogo, de indivíduos identificados como "chefes de família" ou "pais de família".

$\mathrm{Ilm}^{\circ} \mathrm{Ex}^{\mathrm{o}}$ Sr. Conselheiro Manoel José de Freitas Travassos, Presidente da

100 Abaixo-assinado dirigido ao Presidente da Província do Rio de Janeiro, 1873. Fundo Presidentes de Província do Arquivo Público do Estado do Rio de Janeiro.

101 Abaixo-assinado dirigido ao Presidente da Província do Rio de Janeiro, 1875. Fundo Presidentes de Província do Arquivo Público do Estado do Rio de Janeiro. 
Província do Rio de Janeiro

Perante $\mathrm{V}^{\mathrm{a}}$. Ex ${ }^{\mathrm{a}}$. vem respeitosamente os abaixo assinados, residentes no segundo distrito de São João da Barra, ponderar sobre a pretensão de fazer Francisco Roza Junior, também residente neste mesmo distrito, o ? aspirante à carreira do magistério público.

Roza Junio, Ex ${ }^{\circ}$ Sr., não é digno de exercer o lugar que pretende, não só pela sua incapacidade intelectual, como também pela falta de todos aqueles elementos indispensáveis àquele a quem deve ser entregue a instrução, que a bem da falta de um dos predicados indispensáveis - a inteligência - para bem instruir a mocidade e prepará-la para reconhecer os deveres de um verdadeiro cidadão à José Francisco Roza Junior falta-lhe ainda a moralidade, elemento este de tanta importância e necessidade para ser exercido o lugar do magistério.

Há pouco mais de um ano que José Francisco Roza Junior fixou sua residência neste lugar, e nesse curto espaço de tempo já não tem uma só amizade que o honre em consequência de seus maus costumes e moralidade precisa a todo cidadão.

Assim, tendo estabelecido nesta mesma freguesia, digo, distrito, uma aula particular, foi muito concorrida em alunos e em razão do mau trato em palavras e castigos rigorosos tivera que retirarem-se a ponto que ficou sem um só aluno.

Em um distrito tão populoso e deixando de frequentar a aula nem um só aluno, prova exuberantemente que aquele que ocupa tal cargo não merece a imensa confiança dos pais de família e foi sem dúvida por essa razão que pretendendo J F R J a cadeira pública do lugar denominado Bananeiras, e como conota que está provida, então está a espera que seja nomeado para uma outra aonde $\mathrm{V}^{\mathrm{a}}$. Ex ${ }^{\mathrm{a}}$. designar.

Além da falta de dons elementares constitutivos para bem ser preenchido o lugar de professor público - a inteligência e moralidade - o dito Roza Junior é provocador e desordeiro, trazendo assim atropelo aos habitantes desse lugar, perturbando até o próprio lar doméstico!!! ${ }^{102}$

Outro tipo comum de interferência dos "pais de família" era quanto a localização das escolas. É o caso da disputa, em outubro de 1870, pela localização da escola feminina de Jurujuba, em Niterói, a qual alguns moradores pediam ser transferida para o Saco de São Francisco, no mesmo município. O abaixo-assinado dos doze moradores de São Francisco que pretendiam a mudança da escola foi respondido por outro, onde vinte e cinco moradores de Jurujuba solicitavam a manutenção da escola "único benefício que a desditosa população recebia do governo". Em suas explicações quanto a frequência dos alunos, o texto dos moradores de Jurujuba nos permite perceber como esta questão era compreendida pelas classes populares: os alunos iam sempre que podiam, e esta representava uma forma legítima de frequentar a escola. A alternativa que os ditos pais de família ofereciam para que a frequência escolar entrasse nas normas do governo era a assistência aos pais necessitados, para que pudessem manter os filhos na escola.

102 Abaixo-assinado dirigido ao Presidente da Província do Rio de Janeiro, 1871. Fundo Presidentes de Província do Arquivo Público do Estado do Rio de Janeiro. 
Nós abaixo assinados, chefes de família, habitantes do Saco da Jurujuba e Várzea, sabendo que se trata da supressão da escola do sexo feminino desta localidade, único benefício que esta desditosa população recebe do Governo, é de nosso dever levar ao ilustrado conhecimento de V. Exa. que neste lugar existe número mais que suficiente de meninas para a conservação de uma escola pública, e que se muitas deixam de frequentar assiduamente, não quer isso dizer que seus pais as tenham retirado da escola, mas sim que suas posses não permitem que suas filhas frequentem com a precisa assiduidade, porém, contudo, não deixam de frequentar quando podem ${ }^{103}$.

Apenas alguma medida do governo que facilitasse aos pais mais necessitados os meios de ao menos poderem (entreter?) a frequência de suas filhas nas escolas, sob qualquer condição, mesmo no sentido obrigatório, o estado da instrução sairia do abatimento em que jaz, e se tornaria em breve agradável e florescente. Mesmo assim, garantimos a V. Exa. que existem neste lugar mais de 18 meninas que podem frequentar a aula com assiduidade, independente de qualquer favor que o Governo possa conceder ${ }^{104}$.

A mesma polêmica levaria as autoridades provinciais a perceberem a necessidade da criação de mais escolas, uma vez que a frequência de escolas mais ou menos próximas poderia ser impedida pelas condições dos caminhos. O vigário da freguesia, respondendo à consulta do presidente da província afirma que "A natureza do terreno desta paróquia pede sim a criação de mais duas escolas para ambos os sexos. A supressão de qualquer das existentes, ou transferência mesmo, deixará sem pão para a inteligência e por tanto nas trevas da ignorância muitas dezenas de meninos e meninas. $\mathrm{O}$ povo desta freguesia é pobríssimo e a pobreza unida à ignorância dá funestíssimos resultados"105.

A localização também era o teor da requisição de restabelecimento da escola suprimida em Saquarema. Em 12 de julho de 1875, os moradores de Mato Grosso, que haviam deixado de mandar seus filhos à escola pela distância a que esta se localizava da principal povoação local, asseguravam que se o ensino fosse restabelecido em localidade a um quarto de légua do previsto em sua criação, haveria boa frequência. Em sua representação os moradores afirmam-se como conhecedores do lugar e sabedores, por experiência, do ponto mais conveniente para se estabelecer a escola.

Conquanto a escola tivesse sido colocada em uma boa localidade, não estava, porém no centro onde há maior número de famílias, porque, Exmo Sr., do lado sul tem um grande estabelecimento de cultura de açúcar e aguardente e do norte outro igual da mesma cultura. Tanto um como o outro tem uma grande extensão de terras e por consequência não habita ali famílias e somente mais além que com mais ou menos dificuldades alguns

103 Grifos meus.

104 Abaixo-assinado dirigido ao Presidente da Província do Rio de Janeiro, 1870. Fundo Presidentes de Província do Arquivo Público do Estado do Rio de Janeiro.

105 Resposta do vigário da freguesia de São Francisco sobre a consulta da presidência da província, 1870. Fundo Presidentes de Província do Arquivo Público do Estado do Rio de Janeiro. 
mandavam suas filhas a referida escola de Mato Grosso. Contudo, porém, a matrícula e a frequência não era das mais irregulares. É, pois lamentável a falta de uma escola pública neste lugar, porque estão privadas da indispensável educação não só as famílias dos desfavorecidos da fortuna como dos mais abastados. Os abaixo assinados conhecedores do lugar muito bem informam por experiência prática que a melhor localidade para o estabelecimento de uma escola do sexo feminino em suprimento à extinta do Mato Grosso é no lugar Tinguy próximo a fazenda do cidadão Antonio Valentim da Costa Magalhães onde tem uma boa casa pertencente ao mesmo cidadão que presta-se a alugá-la para esse estabelecimento ${ }^{106}$.

A assinatura do dono da casa que se prestaria a ser alugada, que se encontra entre as primeiras do abaixo-assinado, nos atesta embricamento de diversos interesses no processo de estabelecimento de escolas, fossem eles políticos ou econômicos, das autoridades provinciais ou de poderes locais. Mas essas disputas não configuram simplesmente algum tipo de manipulação sobre os moradores das localidades e suas necessidades. As relações de trocas de favores, alianças, negociações, não apagariam o interesse da população local pela escola, nem sua disposição de lutar por ela e interferir em sua implantação e funcionamento.

Destacadas as tentativas de interferência dos: pais de família, moradores, habitantes identificações com que vemos especificados os sujeitos a que chamamos coletivamente de classes populares, nos rumos da educação de seus filhos, temos que a essência de todos esses abaixoassinados era a luta pela instrução compreendida e defendida como uma necessidade. É notável a situação de muitos pais que assinam a rogo requisições em favor de seus filhos de algo que não tiveram para si. É caso de vinte e cinco moradores de Ipiíba, na freguesia de Nossa Senhora da Conceição de Cordeiros, que se dirigiram respeitosamente ante o presidente de província para

(...) representar a necessidade ${ }^{107}$ de instalar-se a escola pública do sexo feminino criada naquela localidade a pedido dos suplicantes por decreto $n$ 2123 de 18 de novembro do ano passado.

Os suplicantes, Ex. Sr, achando-se precisados de uma escola de meninas onde possam educar suas filhas recorreram a V. Exa. cujo amor à instrução se traduz sempre em fatos a fim de que se digne a satisfazer tão palpitante necessidade preenchendo aquela cadeira com a pronta nomeação de uma professora habilitada que se preste a exercer o magistério ${ }^{108}$.

Antes deste, em 20 de fevereiro de 1868, os pais de família, moradores de Teresópolis, sem recursos para dar a indispensável instrução para seus filhos, "imploravam a graça” de ter uma escola

106 Requisição de restabelecimento de escola dirigido ao Presidente de Província, 1875. Fundo Presidentes de Província do Arquivo Público do Estado do Rio de Janeiro.

107 Grifo meu. Nos próximos excertos de abaixo-assinados procurarei destacar, igualmente, o uso textual da palavra "necessidade" para se referir ao requerimento de escolas.

108 Abaixo-assinado dirigido ao Presidente da Província do Rio de Janeiro, 1876. Fundo Presidentes de Província do Arquivo Público do Estado do Rio de Janeiro. 
pública em sua localidade. Já teriam recebido oferta de vagas gratuitas para instrução primária de alunos menos favorecidos, feita por diretores de um Liceu particular que estaria para se implantar a meia légua da parte mais povoada da freguesia, mas este estaria ainda distante, podendo bem poucos utilizar-se da oferta.

Com o mesmo objetivo encontramos a representação dos moradores do lugar denominado Floresta, Freguesia de São Pedro e São Paulo de Ribeirão das Lajes pelo provimento da cadeira do sexo masculino, criada por lei na dita localidade e que se achava vaga pela exoneração do professor. Argumentam os moradores que "um número considerável de meninos existe nessa localidade privados de receber a necessária instrução”. Anexa ao final estava a extensa lista de chefes de família que tinham filhos e filhas na escola.

Lista dos Chefes de Família que têm Filhos e Filhas na Escola

Manoel do Rego de Viveiros

Filhos: João - 16; Antonio, 14; Joaquim, 12; Cândido, 10; Eduardo, 7.

José Felisberto da Silva (A rogo, por José do Rego de Viveiros)

Filhos: João, 8; Delfina, 9; Rita, 6

Manoel Ignácio de Almeida

Filhos: Marcos, 14; Antonio, 10; Luiz, 8; Ilidia (?), 6.

Calisto José da Silva (A rogo por Manoel Inácio de Oliveira)

Filhos: Minigido, 9; Cândida, 6

D. Gertrudes Maria da Conceição (A rogo por Manoel Inácio de Oliveira)

Filhos: ?, 9 anos; Belarmino, 6 anos

Miguel Joaquim de Almeida (?)

Filhos: Mario, 8 anos; Luiza, 7

José Carlos (a rogo por Miguel Joaquim de Almeida)

Filhos: José, 6 anos

Manoel Gomes da Silva

Filhos: Thomaz, 14; João, 12; Miguel, 8; Eliza, 10.

D. Fortunata Maria da Conceição (A rogo por Miguel Joaquim de Almeida)

Filhos: Antonio, 12; Maria, 8

Bernardo de Almeida Mesquitella

Filhos: Antonio, 8, Porsino, 6; Severenia, 12; Inácia, 10, Perseliana, 7

D. Delfina Inácia de Jesus (viúva) (A rogo por Antonio José Geraldo)

Filhos: Manoel, 9; Maria, 8; Ana, 6

Sipriano José Antonio (A rogo por Antonio José Geraldo)

Filhos: Manoel, 10; Graciliano, 8

Jacinta Roza de Oliveira (A rogo por Manoel Mendes da Silva)

Filhos: Severiano, 12

Manoel Lourenço de Carvalho

Filhos: Alarino (?), 7; José, 5; Maria, 8; Ana, 6

João Gomes da Silva

Filho: Binicio, 6

Antonio Gomes da Silva

Filhos: Arlindo, 6

João da Silva Rosa

Filhos: Manoel, 12; Isidia, 9; Ana, 7; Francisco, 6, Narcizo (afilhado), 13

Vitorino Dias Moraes 
Filho: (?), 8

João de Deus Rosa (A rogo por José do Rego de Viveiros)

Filha: não diz o nome

Elias José Tavares

Filhos: Antonio, 9; Vitorino, 7; Maria, 6

Joaquim Dias Morais

Filhos: Cândido Dias de Bonvilar, 12; Perciliana Dias de Bonvilar, 10

José Dias?

Filhos: Pedro Dias ?, 12; João, 8

Rosa Maria de Jesus (A rogo por José Dias ?)

Filhos: Severino, 7; Antonia, 5, Maria, 5

D. Carolina Maria ? (A rogo por Manoel Antonio Ruiz)

Filhos: Lino, 12; Luiz, 10

Manoel ? do Rego (A rogo por Manoel Inácio de Almeida)

Filhos: Manoel, 13; João, 10

Manoel Vital de Brito (A rogo por Antonio G. da Silva)

Filhos: Cândida, 8

José Antonio Nogueira (A rogo por Antonio Gomes da Silva)

Filhos: Nicolau, 6

Antonio Gomes da Silva

Filhos: Julio, 8; Balbina, 7

José Leonardo Fontes

Filhos: Saturnino, 10, José, 8; Elidio, 6; Guilhermina, 10

João Ribeiro Santos (A rogo por José Leandro Fontes)

Filhos: José, 10; Pedro, 8

Laurindo José da Conceição (A rogo por Francisco de Paula Fontes)

Filhos: Manoel, 11

Manoel Fontes Rocha (A rogo por Francisco de Paula Fontes)

Filhos: Leonardo, 13; Cândido, 11; Libivaldo, 9; Rosa, 7

Joaquim Batista Vieira (A rogo por Francisco de Paula Fontes)

Filhos: Manoel, 10; Jovelina, 8

José Alves dos Santos (A rogo por Francisco de Paula Fontes)

Filhos: José, 13; José, 10; Manoel, 8

João Antonio de Bastos (A rogo por Francisco de Paula Fontes)

Filhos: Cândido, 13

Manoel de Melo ? (A rogo por Antonio Paez ? ?)

Filhos: Ana, 10, Antonia, 8, Amélia, 6

Jacinto de Melo ? (A rogo por Antonio Paez ? ?)

Filhos: Francisco, 11; Antonio, 8; José, 7; Maria, 6

Pedro de ? Carvalho (A rogo por Antonio Paez ? ?)

Filhos: Paulino, 8

José Antonio da Silva (A rogo por Reverendo ? Mesquitella)

Filhos: Onófrio, 7; Maria, 8

José de Souza Costa

Filhos: Mariana, 13; Josefa, 11; Firmina, 9

Manoel Machado da Silva (A rogo por José de Souza Costa)

Filhos: Francisco, 9; Cândido, 7; ?, 6

Libano Ferreira da Rosa (A rogo por José de Souza Costa)

Filhos: José, 12

Marcolino Pereira de Farias

Filhos: Mariano, 9; Otávio, 8; Vergília, 6 
Antonio de Souza Nogueira

Filhos: Perciliano Maria de Souza, 12; Cândido José de Souza, 10; Simão Antonio de Souza, 7

João Francisco da Silva (Por Antonio de Souza Nogueira)

Filhos: Laurinda Maria da Conceição, 13; Luiz Francisco da Silva, 10; Nonata Maria da Conceição, 8; Generosa Maria da Conceição, 3

Olímpio José Soares

Filhos: Silvestre, 14; Etelvina, $12^{109}$

Além do número e teor das assinaturas, os textos introdutórios dos abaixo-assinados procuravam apresentar uma convincente argumentação apoiada, tanto nas questões econômicas, quanto jurídicas. Em 4 de maio de 1879, vinte e cinco homens, a maioria com caligrafia firme e duas assinaturas a rogo, chefes de família em duas freguesias de Nossa Senhora da Piedade de Ipiaba, município de Valença, solicitaram da presidência da província, com urgência, a retomada da instrução que ali havia sido interrompida. Em seus argumentos se fez presente a questão de classe, apontando as diferenças de condições entre os filhos de fazendeiros e de pequenos lavradores no acesso à instrução. A educação pública seria uma necessidade dos menos abastados.

É incontestável que aquela Freguesia pode dar uma frequência de 20 alunos pelo mínimo, para poder o governo fazer os dispêndios necessários naquele lugar com a existência de uma escola do sexo masculino, pois há um ano, pouco mais ou menos, que foi suspenso o ensino nas escolas de ambos os sexos. É verdade que a maior parte dos habitantes daquela freguesia são pequenos lavradores, conquanto também hajam importantes fazendeiros, mas por isso mesmo que há indeclinável necessidade do governo manter ali uma escola do sexo masculino, para nela se instruírem os filhos dos menos favorecidos pela fortuna porque certamente os mais abastados mandam educar seus filhos em bons colégios onde recebem a precisa instrução para poderem seguir tal ou tal carreira ${ }^{110}$.

No abaixo-assinado dos moradores de Porto das Caixas, no município de Itaboraí, vemos a qualificação jurídica do argumento. "Usando do direito de petição que lhes outorga a Lei fundamental do Império, vem respeitosamente representarem (sic.) à $\mathrm{V}^{\mathrm{a}} \mathrm{Ex}^{\mathrm{a}}$, em relação à sua freguesia, a necessidade da providência do Artigo 1, § $1^{\circ}$ do Decreto Provincial $n^{\circ} 1490$ de 20 de outubro de 1870". Passa, então a demonstrar que o alto número de alunos, num local de população concentrada "por ser um porto comercial de não pequena importância"111 justificava a abertura de mais uma escola pública, quando a ali existente já atendia mais de sessenta meninos.

109 Abaixo-assinado dirigido ao Presidente da Província do Rio de Janeiro, 1875. Fundo Presidentes de Província do Arquivo Público do Estado do Rio de Janeiro.

110 Abaixo-assinado dirigido ao Presidente da Província do Rio de Janeiro, 1879. Fundo Presidentes de Província do Arquivo Público do Estado do Rio de Janeiro.

111 Abaixo-assinado dirigido ao Presidente da Província do Rio de Janeiro, 1871. Fundo Presidentes de Província do Arquivo Público do Estado do Rio de Janeiro. 
O Estado, cada vez mais, era visto como aquele responsável por atender a necessidade de instrução popular, uma instrução pública, entendido público como o que concerne a todo um povo (ARIÈS \& DUBY, 1997). Segundo Luciano Mendes de Faria Filho, "Estabelecer uma política educacional (...) significou também constituir todo um aparato técnico burocrático para lidar com um serviço (...). Os órgãos estatais criados inicialmente como forma de controle estatal da atividade docente transformam-se, rapidamente, não por acaso, nas principiais formas de saber a respeito do conjunto do serviço da instrução" (FARIA FILHO, 2003, p. 83). Ou seja, órgãos criados para controlar o processo de educação, em suas diversificadas manifestações sociais, passam a ser alvo das reivindicações por atendimento de tal serviço. O povo requererá sua participação no serviço prestado pelo Estado.

Nesse sentido, encontramos o preceito constitucional usado em argumentação dos residentes do quinto distrito rural da cidade de Petrópolis em sua representação movida contra a suspensão de escola na localidade. "Submissa e respeitosa", mas incisivamente, o texto dialoga com a presidência da província, lembrando-lhe que, a criação das escolas era um cumprimento de preceito constitucional. Era a satisfação de uma necessidade, uma vez que a instrução seria indispensável. Antes de serem fechadas, havia nas escolas "a maior assiduidade que a dispersão da população e as condições físicas e locais permitiam”. Segue explicando as condições de frequência a essas escolas.

Para bem se poder julgar do empenho que os abaixo assinados tem na instrução de seus filhos, e dos esforços que empregam para consegui-la, necessário é ponderar a $\mathrm{V}^{\mathrm{a}}$. $\mathrm{Ex}^{\mathrm{a}}$. que o distrito onde residem e cuja população é cerca de 350 fogos, se acha derramada pelo território de mais de 9 quilômetros de extensão e de cerca de 6 em largura, é sujeito como a cidade de Petrópolis a repetidas e copiosas chuvas, não tendo como ela tem, caminhos e pontes que prestem trânsito possível e seguro, nessas ocasiões, mesmo a homens, quanto mais a crianças. De uma tal falta resulta que os alunos muitas vezes não podem comparecer nas escolas às horas precisas, outras vezes delas saírem mais cedo, e logo que as trovoadas se manifestam, a fim de prevenir fatais acontecimentos, e outras, finalmente, a não saírem de suas casas, com perda de seu adiantamento e bem contra suas vontades $^{112}$.

O esforço aqui narrado, ocorrido em diversos pontos da corte e da província do Rio de Janeiro pela obtenção de escolas para localidades desassistidas, atesta que as classes populares compreenderam o papel social da escola governamental e seu projeto educacional vencedor. Em lugar de um grande movimento de rechaço e rebeldia contra a obrigatoriedade escolar, encontramos a luta daqueles sujeitos por um serviço que o Estado defendia como basilar, mas, ao mesmo tempo, 
não dava conta de generalizar pelo vasto território do país. Segundo Adriana Silva, o processo de construção do Estado imperial e da própria classe senhorial, teve na instrução pública, um instrumento inegável, entretanto, a autora evidencia suas contradições quando “ (...) ao mesmo tempo que foi fundamental a expansão desse tipo de ensino para a difusão de uma determinada noção de "ordem" em meio ao mundo da "desordem” como propôs Mattos, esta mesma expansão, apesar das tentativas de controle da classe senhorial, pode ser utilizada no sentido inverso, ou seja, potencializando as ações do mundo da desordem e do mundo do trabalho com o objetivo de romperem, dentro das suas possibilidades, com as hierarquizações existentes nesses três mundos" (SILVA, 2000, p. 61).

O texto do abaixo-assinado anteriormente citado mostra, em fim, como a luta por escolarização poderia ser, em si mesma, pedagógica, ao afirmar que "Apesar de árduas contrariedades, os abaixo-assinados têm persistido na resolução de instruir seus filhos e o exemplo que eles têm dado tem produzido o aumento do número de alunos dessas escolas...”. Pelo exemplo, alguns pais conseguiam ensinar a outros a importância da instrução, ou a importância de acreditar e empreender a própria luta por seus direitos e de seus filhos, já que a abertura de escolas é percebida por eles como "preceito constitucional". Não deixava de haver aí um contexto educativo, a aprendizagem da política feita em interface com a escola, não em sala de aula, mas por outras vias. 


\section{Considerações finais}

A escrita precisa de um ponto final, enquanto a pesquisa não termina nunca, mais uma vez a Operação Historiográfica (CERTEAU, 1982) vem em nosso auxílio. Ainda há muito a dizer sobre as experiências educacionais, os saberes das classes populares oitocentistas, tamanha é sua complexidade. Padeiros, tipógrafos, cocheiros, guarda-livros, sapateiros, caixeiros, lavradores, ou simplesmente, pais de família e tantos mais que não estão presentes aqui como é o caso dos membros das sociedades carnavalescas, sugestão da banca de qualificação que não foi possível desenvolver. Também foi sub explorado o universo próprio dos escravos, ainda que estes sujeitos tenham sido considerados o tempo todo no interior dos debates sobre educação das classes populares e formação da classe trabalhadora, não por não considerar sua primordial importância, mas pelo direcionamento das fontes primárias e da própria formação teórica da pesquisadora.

O campo da história da educação já tem delimitada a necessidade da busca por compreensão de outros espaços educativos que estão além da própria escola (FARIA FILHO, 2003; VIDAL \& BICCAS, 2008), porém precisamos aprofundar, cada vez mais, os esforços nessa direção. Esta é uma das condições para que a instituição escolar da qual nós mesmos, professores/pesquisadores somos, em certa medida, representantes, ao olhar horizontalmente para seus educandos como portadores de experiências e saberes relevantes, possa repensar sua própria formação e, assim, as razões de suas crises.

Encontrar e analisar, com rigor científico, educações externas à forma escolar, culturalmente desvalorizadas, e historicamente silenciadas, não é uma tarefa fácil, especialmente em se tratando do cotidiano de homens e mulheres do século retrasado. É preciso ter consciência de algumas peculiaridades do intento - uma narrativa mais ou menos difusa, mais ou menos circular, a moda da dinâmica do próprio objeto quando era(m) sujeito(s).

Não foi o objetivo, contudo, relatar "experiências" com um fim em si mesmas. Trabalhando com as balizas dadas ao termo por E. P. Thompson, elas participaram desta análise, não de forma condescendente aos seres sociais, especialmente às pessoas comuns. Puderam imprimir dinâmica ao olhar histórico quando afirmada a capacidade da luta popular em transformar uma educação doada ao povo em um direito social. Tal formulação não foi um slogan teórico, mas sim um movimento, ou conjunto de movimentos que deixaram marcas no tempo e indícios na documentação.

O historiador inglês afirma que a experiência surge espontaneamente no ser social, mas não sem pensamento.

Surge porque homens e mulheres (e não apenas filósofos) são racionais, e refletem sobre o que acontece a eles e ao seu mundo. Se tivermos que empregar a (difícil) noção, de que o ser social determina a consciência social, como iremos supor que isso se dá? Certamente não iremos supor que 
o "ser" está aqui, com uma materialidade grosseira da qual toda idealidade foi abstraída, e que a "consciência", (como idealidade abstrata) está ali. Pois não podemos conceber nenhuma forma de ser social independentemente de seus conceitos e expectativas organizadores, nem poderia o ser social reproduzir-se um único dia sem o pensamento. O que queremos dizer é que ocorrem mudanças no ser social que dão origem à experiência modificada, e essa experiência é determinante, no sentido de que exerce pressão sobre a consciência social existente, propõe novas questões e proporciona grande parte do material sobre o qual se desenvolvem os exercícios intelectuais mais elaborados (THOMPSON, 1981, p.16).

Foi a partir dessa concepção que olhamos para uma greve de marmoristas, ou de cocheiros, para a leitura em voz alta de um jornal por padeiros, para um memorial das condições de trabalho de chapeleiros, a constituição de uma biblioteca por tipógrafos, no mais, para toda a demanda intelectual de associar-se em cada uma das categorias aqui abordadas. Mais do que associarem-se, editarem periódicos, promoverem escolas, expressarem-se sobre o valor da instrução por meio de jornais e revistas, afirmar este valor nos estatutos de suas organizações. Toda essa dinâmica estava presente, também, em outras esferas da vida desses sujeitos, quando não sob a identidade de trabalhadores, fosse sob a condição de moradores em áreas da corte e da província do Rio de Janeiro não contempladas pelo Estado com escolas. Ali estavam eles, reivindicando instrução com seus abaixo-assinados. E não reclamavam uma instrução qualquer, mas permitiam-se interferir, dentro dos limites, na escolha do professor da escola. Utilizavam seu poder de retirar o filho(a) da escola no momento em que julgassem necessário ou conveniente.

Podemos, a partir da articulação dessas experiências, vislumbrar a magnitude do papel da educação na formação das classes trabalhadoras no Rio de Janeiro, fator nem sempre destacado pela historiografia do mundo trabalho. E, por outro lado, a importância desse mesmo processo de formação nas lutas populares pelo direito à educação, entendida também como acesso à escola. Lutas que foram constitutivas da própria instituição escolar.

Gostaria de fechar esta reflexão explicitando como a vivência da produção de conhecimento acadêmico emaranhou-se à experiência da atividade profissional de professora na educação básica condição mais "proletarizada" do trabalho de educador. Recentemente, ao preparar uma aula sobre movimento operário no século XIX, conteúdo curricular da disciplina de história para o oitavo ano do ensino fundamental, reli o poema de Vinicius de Moraes: O operário em construção. Não era a primeira vez que trabalhava com ele em sala de aula, nem tampouco que o lia. Mas, naquele momento, ele ganhou uma dimensão nova para mim. Observei sentidos que antes não observara, nas descobertas do operário em construção. Entendi o que antes "passara os olhos" superficialmente, percebi que a construção tratada no poema era de si [do operário] e de uma classe, desenvolvida tanto pelo trabalho manual do operário ao exercer a profissão, quanto por seu trabalho 
intelectual de exercício da razão.

Deixar falar a poesia não destoa dessa tese, pois que esse tipo de linguagem era presença constante nos periódicos aqui analisados, fazia parte dos recursos pedagógicos usados pela imprensa operária.

Mas ele desconhecia

Esse fato extraordinário:

Que o operário faz a coisa

E a coisa faz o operário.

De forma que, certo dia

À mesa, ao cortar o pão

O operário foi tomado

De uma súbita emoção

Ao constatar assombrado

Que tudo naquela mesa

- Garrafa, prato, facão -

Era ele quem os fazia

Ele, um humilde operário,

Um operário em construção.

(...)

Tudo, tudo o que existia

Era ele quem o fazia

Ele, um humilde operário

Um operário que sabia

Exercer a profissão.

Ah, homens de pensamento

Não sabereis nunca o quanto

Aquele humilde operário

Soube naquele momento!

Naquela casa vazia

Que ele mesmo levantara

Um mundo novo nascia

De que sequer suspeitava.

O operário emocionado

Olhou sua própria mão

Sua rude mão de operário

De operário em construção

E olhando bem para ela

Teve um segundo a impressão

De que não havia no mundo

Coisa que fosse mais bela.

Foi dentro da compreensão

Desse instante solitário

Que, tal sua construção

Cresceu também o operário.

Cresceu em alto e profundo

Em largo e no coração

E como tudo que cresce

Ele não cresceu em vão 
Pois além do que sabia

- Exercer a profissão -

O operário adquiriu

Uma nova dimensão:

A dimensão da poesia.

E um fato novo se viu

Que a todos admirava:

O que o operário dizia

Outro operário escutava.

Ao tentar captar de forma objetiva as representações de educação das classes populares, guardo a consciência de que como "homem de pensamento", considerado o fator de gênero na licença poética, não saberei nunca o que aqueles operários souberam naquele momento. Porém, passados mais de dois séculos, gratifico-me se puder trazer à tona o esforço daqueles homens e mulheres em sua conquista da "dimensão da poesia", da consciência, do simples ato de ler e escrever. Conquista que não foi de indivíduos isolados, pois como Vinicius nos ajuda a ver, dava-se um "fato novo" naquele momento, na segunda metade do século XIX, "O que o operário dizia, outro operário escutava". É esse o sentido do educar-se das classes populares. 


\section{Bibliografia}

ABREU, Martha. Civilização. In: VAINFAS, Ronaldo. Dicionário do Brasil Imperial (18221889). Rio de Janeiro: Objetiva, 2002.

ABREU, Martha. Cultura popular, um conceito e várias histórias. In: SOIHET, R. \& ABREU, Martha. (org). Ensino de História. Rio de Janeiro, Casa da Palavra, FAPERJ, 2003.

ANTELO, Raul (org). João do Rio. A Alma Encantadora das Ruas. São Paulo: Companhia das Letras, 1997.

ARIÈS, P. \& DUBY, G. Poder Público e Poder Privado. In: ARIÈS, P. \& DUBY, G. História da Vida Privada. Vol. 2. São Paulo: Companhia das Letras, 1997.

ARROYO, Miguel G. Pedagogias em movimento. O que temos a aprender dos Movimentos Sociais. In: Currículo Sem Fronteiras, v. 3, n.1, Jan/Jun de 2003.

BAIA HORTA, José Silvério. Direito à educação e obrigatoriedade escolar. In: Cadernos de Pesquisa, n. 104, Julho de 1998.

BARATA, Alexandre. Luzes e sombras: a ação da maçonaria brasileira (1870-1910). Campinas: UNICAMP, 1999.

BARBOSA, Marialva. História Cultural da Imprensa. Brasil 1800 - 1900. Rio de Janeiro: Mauad X, 2010.

BATALHA, Cláudio H. M. Sociedades de trabalhadores no Rio de Janeiro do século XIX: algumas reflexões em torno da formação da classe operária. Cadernos AEL, v. 6, n. 10/11, 1999, Sociedades Operárias e Mutualismo.

BATALHA, Cláudio H. M. Dicionário do Movimento Operário. Rio de Janeiro do século XIX aos anos 1920, militantes e organizações. São Paulo: Editora Fundação Perseu Abramo, 2009. 
BATALHA, Cláudio H. M. Cultura Associativa no Rio de Janeiro da Primeira República. In: BATALHA, Cláudio H. M; SILVA, Fernando Teixeira da; FORTES, Alexandre. Culturas de Classe. Campinas, SP: Editora da UNICAMP, 2004.

BICCAS, Maurilane de Souza. Creches comunitárias. Como se constroem e se institucionalizam. Dissertação de Mestrado. Faculdade de Educação da Universidade de Minas Gerais. Orientadora: Prof. Dra Magda Becker Soares. Belo Horizonte, 1995.

BLOCH, Marc. A observação histórica. In: A apologia da história ou o ofício do historiador. Rio de Janeiro: Jorge Zahar Editor, 2001.

BOOBIO, N. Sociedade Civil. in: BOBBIO, N., MATTEUCCI, N. \& GIANFRANCO, P. Dicionário de Política. 12a ed. Brasília: UNB, 1999. Vol. 2.

CANÁRIO, Rui. Educação de Adultos. Um campo e uma problemática. Lisboa: ANEFA e EDUCA, 2000.

CARVALHO, José Murilo. Os Bestializados. O Rio de Janeiro e a República que não foi. $3^{\text {a }}$ ed. São Paulo: Companhia das Letras, 2006.

CERTEAU, Michel de. A operação historiográfica. In: A escrita da História. Rio de Janeiro: Forense Universitária, 1982.

CHALHOUB, Sidney. Machado de Assis Historiador. São Paulo: Companhia das Letras, 2003.

CHALHOUB, Sidney. Solidariedade e Liberdade: sociedades beneficentes de negros e negras no Rio de Janeiro na segunda metade do século XIX. In: Quase Cidadão. Histórias e antropologias da pós-emancipação no Brasil. Rio de Janeiro: FGV, 2007.

CHALHOUB, Sidney. Visões da Liberdade. Uma História das Últimas Décadas da Escravidão na Corte. São Paulo: Companhia das Letras, 1990.

CHALHOUB, Sidney. Trabalho, Lar e Botequim. Campinas: Editora da UNICAMP, 2001. 
CHARTIER, Anne-Marie. Dos Abecedários aos Métodos de Leitura: gênese do manual moderno antes das leis Ferry (1881). In: CHARTIER, Anne-Marie. Práticas de Leitura e Escrita: história e atualidade. Belo Horizonte: Autêntica/Ceale, 2007.

CHARTIER, Roger. O mundo como representação. In: Estudos Avançados, n. 11, 1991.

COSTA, Ana Luiza Jesus da. À luz das lamparinas. As escolas noturnas para trabalhadores no município da Corte (1860-1889). Dissertação de Mestrado, Proped-UERJ, 2007.

DAVIES, Natalie Z. Culturas do Povo. Sociedade e Cultura no Início da França Moderna. Rio de Janeiro: Paz e Terra, 1990.

DUARTE, Leila. Pão e Liberdade, uma história de padeiros escravos e livres na virada do século XIX. Cadernos do Arquivo I. Rio de Janeiro: Mauad: FAPERJ, 2002.

FARIA FILHO, Luciano Mendes de. O processo de escolarização em Minas Gerais: questões teórico metodológicas e perspectivas de análise. In: FONSECA, Thais Nívea \& VEIGA, Cynthia G. História e Historiografia da Educação no Brasil. Belo Horizonte: Autêntica, 2003.

FARIA FILHO, Luciano Mendes de; VIDAL, Diana Gonçalves. Os tempos e os espaços escolares no processo de institucionalização da escola primária no Brasil. In: Revista Brasileira de Educação. Mai/Jun/Jul/Ago 2000, no 14.

FERREIRA, Maria de Nazareth. A Imprensa Operária no Brasil 1880 - 1920. Petrópolis: Vozes, 1978.

FOUCAULT, Michel. Microfísica do Poder. Rio de Janeiro: Graal 2003.

FRAGO, Antonio Viñao. Leer y escribir (siglos XIX-XX). In: Leer y escribir. Historia de dos prácticas culturales. Mexico, Educación, voces y vuelos, I.A.P., 1999.

GALVÃO, Ana Maria de Oliveira \& DI PIERRO, Maria Clara. Preconceito Contra o Analfabeto. São Paulo: Cortez, 2007. 
GONDRA, José Gonçalves \& SCHUELER, Alessandra. Educação, poder e sociedade no império brasileiro. São Paulo: Cortez, 2008.

GRAFF, Harvey J. Os labirintos da alfabetização. Reflexões sobre o passado e o presente da alfabetização. Porto Alegre: Artes Médicas, 1987.

GRAMSCI, Antonio. Os intelectuais e a organização da cultura. Rio de Janeiro: Civilização Brasileira, $4^{\mathrm{a}}$ ed. 1982.

GOUVÊA, Maria de Fátima Silva. O império das províncias. Rio de Janeiro, 1822-1889. Rio de Janeiro: Civilização Brasileira, 2008.

HÉBRARD, Jean. Por uma bibliografia material das escritas ordinárias: o espaço gráfico do caderno escolar (França séculos XIX - XX). In: Revista Brasileira de História da Educação. Editora Autores Associados/SBHE, jan-jun de 2001, n 1, pp. 115-141.

HILL, Christopher. O Mundo de Ponta Cabeça. Ideias Radicais Durante a Revolução Inglesa de 1640. São Paulo: Companhia das Letras, 1987

HILSDORF, Maria Lucia Spedo. O aparecimento da escola moderna. Uma história ilustrada. Belo Horizonte: Autêntica, 2006.

LACERDA, David P. Experiência associativa no Império: sociedades mutuais de trabalhadores livres na cidade do Rio de Janeiro (segunda metade do século XIX). Anais do XIII encontro de história da Anpuh-Rio, 2008.

LAMPEDUSA, Tomasi di. O Gattopardo. Rio de Janeiro: Bestbolso, 2007.

LUZ, I. M. Negros com-passos letrados:a ação educativa da Sociedade dos Artistas Mecânicos e Liberais. In: GALVÃO, Ana Maria de Oliveira; MELO, Juliana Ferreira de; SOUZA, Maria José Francisco de; RESENDE, Patrícia Cappuccio. (Org.). História da cultura escrita: séculos XIX e XX. 1 ed. Belo Horizonte: Autêntica, 2007, v. 1, p. 9-437. 
MACIEL, Francisca Izabel Pereira. História da Alfabetização: Perspectivas de Análise. In: VEIGA, Cynthia Greive \& FONSECA, Thais Nivia de Lima e Fonseca (org). História e Historiografia da educação no Brasil. Belo Horizonte: Autêntica, 2003.

MACIEL, Laura Antunes. Do "O povo não sabe ler" para uma história dos trabalhadores da palavra. in: MACIEL, Laura Antunes; ALMEIDA, Paulo Roberto; KHOURY, Yara Aun (org).Outras histórias: memórias e linguagens. São Paulo: Olho d'água, 2006.

MARTINS, Maria Fernanda Vieira. A Velha Arte de Governar: o Conselho de Estado no Brasil Imperial. In: Topoi, v. 7, n. 12, jan - jun de 2006, pp. 178 - 221.

MATTOS. Ilmar Rohloff de. A formação do povo. In: O Tempo Saquarema. A formação do Estado Imperial. $3^{\text {a }}$ ed. Rio de Janeiro: Acess, 1994.

MAUSS, Marcel. Ensaio Sobre a Dádiva: forma e razão da troca nas sociedades arcaicas. In: MAUSS, Marcel. Sociologia e Antropologia. São Paulo: Cosac Naify, 2003.

MENESES, Ulpiano Bezerra de. A exposição museológica e o conhecimento histórico. in: VIDAL, Diana Gonçalves \& FIGUEIREDO, Betânia Gonçalves (org). Dos gabinetes de curiosidade aos museus modernos. Belo Horizonte: Argumento, 2005.

MENDONÇA, Sonia Regina. Estado e Sociedade. In: MATTOS, Marcelo Badaró; MOTTA, Márcia; MENDONÇA, Sonia; FONTES, Virgínia. História Pensar e Fazer. Rio de Janeiro: Laboratório Dimensões da História - UFF, 1998.

MORAES, Carmem Sylvia Vidigal. A Socialização da Força de Trabalho: instrução popular e qualificação profissional no Estado de São Paulo - 1873 a 1934. Tese de doutorado, São Paulo, FEUSP, 1990.

MORAES, Vinicius de. O Operário em Construção. http://viniciusdemoraes.com.br/site/article.php3?id_article=206 (Acesso em 08 de novembro de 2011).

MOREL, Marco. As transformações dos espaços públicos. Imprensa, atores políticos e 
sociabilidades na cidade imperial (1820-1840). São Paulo: Hucitec, 2005.

MOREL, Marco. Os primeiros passos da palavra impressa. In: MARTINS, Ana Luiza \& DE LUCA, Tania Regina (org.). História da Imprensa no Brasil. São Paulo: Contexto, 2011.

NAGLE, Jorge. Educação e sociedade na primeira República. São Paulo: Editora pedagógica universitária/MEC, 1976.

NICOLAU, Jairo. História do Voto no Brasil. Rio de Janeiro: Jorge Zahar Editor, 2002.

PEREIRA, Ronaldo. Associações de Classe Profissionais e Beneficentes no Rio de Janeiro (1860-1889). in: Diálogos, DHI/UEM, n. 3: 191-211, 1999.

POPINIGIS, Fabiane. As Sociedades Caixeirais e o "Fechamento das Portas" no Rio de Janeiro (1850-1912). Cadernos AEL, v. 6, n. 10/11, 1999, Sociedades Operárias e Mutualismo.

REIS, João José. Domingos Sodré. Um sacerdote africano. Escravidão, liberdade e candomblé na Bahia do século XIX. São Paulo: Companhia das Letras, 2008.

SAINT-EXUPÉRY, Antoine. O Pequeno Príncipe. Rio de Janeiro: Agir, 1993.

SAVAGE, Mike. Classe e História do Trabalho. In: BATALHA, Cláudio; SILVA, Fernando Teixeira da; FORTES, Alexandre. Culturas de Classe. Campinas: Editora da UNICAMP, 2004.

SCHUELER, Alessandra Frota Martinez. Educar e Instruir: a instrução popular no Rio de Janeiro, Dissertação de Mestrado, Niterói, UFF, 1997. Orientadora: Martha Campos Abreu.

SILVA, Adriana Maria Paulo da. A escola de Pretextato dos Passos e Silva: questões a respeito das práticas de escolarização no mundo escravista. In: Revista Brasileira de História da Educação. N 4, jul/dez 2002.

Aprender com perfeição e sem coação: uma escola para meninos pretos e pardos na Corte. 1a. Ed. Brasília: Editora Plano, 2000. 
SOIETH, Raquel. Introdução. In: ABREU, Martha e SOIETH, Raquel (org). Ensino de História. Conceitos, Temáticas e Metodologia. Rio de Janeiro: Casa da Palavra, 2003.

THOMPSON, E. P. A formação da classe operária inglesa. A árvore da liberdade. Trad. Denise Bottmann. Rio de Janeiro: Paz e Terra, 2004. Vol. 1.

THOMPSON, E. P. A formação da classe operária inglesa. A maldição de Adão. Trad. Denise Bottmann. Rio de Janeiro: Paz e Terra, 2004. Vol. 2.

THOMPSON, E. P. A formação da classe operária inglesa. A força dos trabalhadores. Trad. Denise Bottmann. Rio de Janeiro: Paz e Terra, 2002. Vol. 3.

THOMPSON, E. P. A miséria da teoria. Ou um planetário de erros. Uma crítica ao pensamento de Althusser. Rio de Janeiro: Zahar editores, 1981.

THOMPSON, E. P. Educação e experiência. in: Os românticos. A Inglaterra na era revolucionária. Trad. Sérgio Moraes Rego Reis. Rio de Janeiro: Civilização Brasileira, 2002.

THOMPSON, E. P. Patrícios e plebeus. in: Costumes em comum. São Paulo: Companhia das Letras, 2008.

THOMPSON, E. P. Senhores e Caçadores. Rio de Janeiro: Paz e Terra, 1987.

VARELA, Julia \& ALVAREZ-URIA, Fernando. A maquinaria escolar. in: Teoria $e$ educação. № 6, 1992.

VEIGA, Cyntia Greive. A escolarização como projeto de civilização. In: Revista Brasileira de Educação, 2002, nº 21.

VIDAL, Diana Gonçalves \& BICCAS, Maurilane de Souza. As Múltiplas Estratégias de Escolarização do Social em São Paulo (1770-1970). Cultura e prática escolares. In: VIDAL, Diana Gonçalves (org.). Educação e Reforma. O Rio de Janeiro nos anos 1920-1930. Belo Horizonte: Argvmento, 2008. 
VINCENT. Guy; LAHIRE, Bernard \& THIN, Daniel. Sobre a história e a teoria da forma escolar. Educação em revista, 2001.

VISCARDI, Cláudia Maria Ribeiro. Estratégias Populares de Sobrevivência: o mutualismo no Rio de Janeiro Republicano. In: Revista Brasileira de História. São Paulo, v. 29, n. 58, p. 291315, 2009.

VITORINO, Artur José Renda. Escravismo, proletários e greve de compositores tipógrafos de 1858 no Rio de Janeiro. Cadernos AEL, v. 6, n. 10/11, 1999, Sociedades Operárias e Mutualismo.

WISSENBACH, Maria Cristina Cortez. Cartas, procurações, escapulários e patuás: os múltiplos significados da escrita entre escravos e forros na sociedade oitocentista brasileira. In: Revista Brasileira de História da Educação. Editora Autores Associados/SBHE, jul-dez de 2002, $\mathrm{n}^{\circ}$ 4, pp. 103-122. 


\section{Fontes}

Abaixo-assinados diversos. 1870 - 1879. Fundo Presidentes de Província do Arquivo do Estado do Rio de Janeiro.

Assistência Pública e Privada no Rio de Janeiro (Brasil). História e Estatísticas. Município do Rio de Janeiro. Comemoração do Centenário da Independência Nacional. Typographia do Anuário do Brasil, Rio de Janeiro, 1922.

BRASIL. Constituição da República Federativa do Brasil, 1988. http://www.planalto.gov.br/ccivil_03/constituicao/constitui\%C3\%A7ao.htm

BRASIL. Constituição Política do Império do Brasil (De 25 de março de 1824). http://www.planalto.gov.br/ccivil_03/Constituicao/Constitui\%C3\%A7ao24.htm

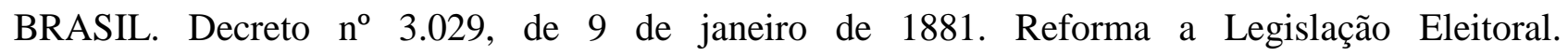
http://www.tse.jus.br/hotSites/glossario-eleitoral/termos/anexos/textos/html_leis/lei_saraiva.htm

BRASIL. Decreto no. 8213 - de 13 de agosto de 1881. Regula a execução da Lei n. 3029 de 9 de Janeiro do corrente ano que reformou a legislação eleitoral.

Códices Escolas Subvencionadas, Arquivo da Cidade do Rio de Janeiro

$11-3-30$

$11-3-40$

$11-4-16$

Estatutos da Sociedade Bem-Estar dos Caixeiros no Rio de Janeiro. Rio de Janeiro, Typ. americana de I. P. da Costa. Rua de Traz do Hospício, n. 160. 1836.

Estatutos da Sociedade Protetora dos Empregados Públicos a que se refere o Decreto N. 6052 de 13 de dezembro de 1875. Rio de Janeiro, Typ. de João M. A. de Aguiar, Rua da Ajuda, 106. 1876.

Estatutos da Sociedade União Beneficente Vinte e Nove de Julho. Rio de Janeiro, Typ. de Domingos Luiz dos Santos, Rua Nova do Ouvidor, 20. 1861. 
Estatutos da Imperial Sociedade União Beneficente dos Guardas Nacionais da qual é augusto protetor sua majestade o imperador. Rio de Janeiro, Typ. de Domingos Luiz dos Santos, Travessa do Ouvidor, $\mathrm{n}^{\circ} 20.1860$.

Estatutos da Sociedade Auxiliadora das Artes e Ofícios e Beneficente dos Sócios e Suas Famílias. Rio de Janeiro, Typ Fluminense de Brito \& Comp. Praça da Constituição, nº 51, 1835.

Estatutos do Congresso de Beneficência e Instrução (antigo Operário de Beneficência) Sob a Alta Proteção de S. M. O Imperador. Rio de Janeiro, Typ. Cosmopolita, rua d'Alfandega, n. 215, 1889.

Estatutos da Sociedade Beneficente Bethencourt da Silva no Rio de Janeiro. Instalada em 8 de maio de 1882. Aprovados em Assembléia Geral de 9 de julho de 1886 - $1^{\text {a }}$ reforma -1886 . Rio de Janeiro, Typ. Camões - Fonseca, Irmão \& Souza Lima, Rua do Hospício, 139. 1886.

Estatutos da Sociedade concórdia Beneficente Vinte e Oito de Abril. Instalada em Niterói a 28 de abril de 1875. Rio de Janeiro, Tipographia e Litographia Carioca. Rua Teóphilo Ottoni, 145, 1875.

Estatutos do Club dos Libertos Contra a Escravidão. Typ. de G. Leuzinger e Filhos, R. do Ouvidor, 91. 1882.

Estatutos da Associação Tipográfica Fluminense. Instalada a 25 de dezembro de 1853. Rio de Janeiro, Typ. Imparcial de M. J. Pereira da Silva Junior, Rua da Carioca, n. 32, 1854.

Ministério do Império. Consulta de 22 de fevereiro de 1882. Sobre a aprovação dos Estatutos da Sociedade "Socorros Mútuos Marques de Pombal. Arquivo Nacional. Fundo Conselho de Estado. Caixas Topográficas.

Ministério do Império. Consulta de $1^{\circ}$ de março de 1882. Sobre a aprovação dos novos Estatutos da Sociedade Beneficente dos Artistas em São Cristóvão. Fundo Conselho de Estado. Arquivo Nacional. Arquivo Nacional. Fundo Conselho de Estado. Caixas Topográficas.

Ministério do Império. Consulta de 21 de agosto de 1882. Sobre a aprovação da Associação de Socorro Familiar Homenagem a Serpa Pinto. Arquivo Nacional. Fundo Conselho de Estado. Caixas Topográficas. 
Ministério do Império. Consulta de 8 de dezembro de dezembro de 1880. Sobre a aprovação dos estatutos da Associação Bahiana de Beneficência. Arquivo Nacional. Fundo Conselho de Estado. Caixas Topográficas.

Ministério do Império. Consulta de 28 de novembro de 1879. Sobre as alterações feitas em diferentes artigos dos Estatutos da Sociedade de Beneficência dos Artistas da Construção Naval. Arquivo Nacional. Fundo Conselho de Estado. Caixas Topográficas.

Ministério do Império. Consulta de 30 de junho de 1880. Sobre a aprovação dos Estatutos da Sociedade Beneficente Filhos da Luz. Arquivo Nacional. Fundo Conselho de Estado. Caixas Topográficas.

Ministério do Império. Consulta de 3 de fevereiro de 1879. Sobre os novos Estatutos da Sociedade da Imperial Sociedade União Beneficente 29 de julho. Arquivo Nacional. Fundo Conselho de Estado. Caixas Topográficas.

Ministério do Império. Consulta de 4 de abril de 1863. Sobre os Estatutos da Sociedade que se pretende estabelecer nessa Corte e denominada "Industrial de Beneficência". Arquivo Nacional. Fundo Conselho de Estado. Caixas Topográficas.

Ministério do Império. Consulta de 17 de junho de 1872. Sobre a aprovação dos estatutos da “Sociedade União Beneficente dos Cocheiros". Arquivo Nacional. Fundo Conselho de Estado. Caixas Topográficas.

Parecer do presidente de província do Rio de Janeiro sobre as reformas dos estatutos da Sociedade Concórdia Beneficente 28 de abril. 18 de março de 1879. Fundo Presidentes de Província. Arquivo do estado do Rio de Janeiro.

Pedido, à presidência da província para extração de loteria, pela União Beneficente Niteroiense, 1 de setembro de 1876. Fundo Presidentes de Província. Arquivo do estado do Rio de Janeiro.

Pedido de aprovação para reforma dos estatutos pela Sociedade Amparo Operário. 14 de outubro de 1880. Fundo Presidentes de Província. Arquivo do estado do Rio de Janeiro.

Pedido de auxílio pela Sociedade Concórdia Beneficente, para resolução de divergência interna, 
pede à presidência sua interpretação dos estatutos sobre o caso. 9 de junho de 1877. Fundo Presidentes de Província. Arquivo do estado do Rio de Janeiro.

Programa da Sessão Solene do Corpo Coletivo União Operária Comemorativa da Independência do Império em 7 de Setembro de 1885. Honrada com a augusta presença de SS. MM. II. 7 de setembro de 1885. (Impresso, Obras Raras, Biblioteca Nacional).

Projeto de Estatutos da Sociedade de Socorros Mútuos Montepio dos Conservadores. 15 de outubro de 1881. Fundo Presidentes de Província. Arquivo do estado do Rio de Janeiro.

Periódicos:

A Consciência Nacional. Jornal Político-Social. 2 de dezembro de 1877. $\mathrm{N}^{\mathrm{o}} 1$ (único exemplar). Rio de Janeiro, Typografia de Domingos Luiz dos Santos, Rua 7 de setembro n. 142.

A Redenção. Periódico da Penitenciária do Estado do Rio de Janeiro. 1914.

Echo Popular. Órgão das Classes Operária, Industrial e Comercial. Rio de Janeiro, Typ. Rua da Uruguaiana, 170, 1890.

Força Nova. Rio de Janeiro, R. General Câmara, 148, 1904.

Gazeta dos Operários. Publicação diária. Propriedade de Operários. Rio de Janeiro, Typ. Fluminense, 1875.

Gazeta Operária: órgão dedicado especialmente aos interesses dos artistas e operários. Ano I, 8 a 22 de janeiro de 1881, nº 1 a 4. Rio de Janeiro, Typ. Rua Sete de setembro, nº 62.

Gazeta Suburbana. Edição especial comemorativa da Solene Redenção dos Escravos da Província do Ceará. Aos 25 dias do mês de março de 1894. Rio de Janeiro, Typ. Econômica, 1884.

Jornal dos Typographos. Rio de Janeiro, Typ. De Peixoto e Leite, 1858.

Lincoln: Periódico do Clube Gutemberg, consagrado à propaganda abolicionista. Rio de Janeiro, 
Typ. Central, 1883.

O Artista: periódico dedicado à indústria e principalmente as artes. 1870-1871 Rio de Janeiro, Typ. de Aranha Guimarães.

O Aspirante: Periódico Literário e Artístico dos Alunos do Liceu de Artes e Ofícios. 1881 - 1882. Rio de Janeiro, Typ. Cosmopolita.

O Marmorista. Órgão de propaganda dos operários marmoristas. Rio de Janeiro, Papelaria e Typ. Vianna \& C., Rua 7 de setembro, 197. 1906 - 1907.

O Panificador. Órgão dedicado aos interesses da classe dos empregados em padaria. Rio de Janeiro, 1900, ano II, $\mathrm{n}^{\circ}$ 2, 1 de janeiro; $\mathrm{n}^{\circ}$ 3, 18 de janeiro; $\mathrm{n}^{\circ}$ 4, 11 de fevereiro.

O Proletário. Hebdomadário artístico, literário e recreativo. Rio de Janeiro, Typ. da Reforma, 18771878 , N. 1, 3, 7-10, 14.

O Socialista. Órgão de um clube. Jornal político, chistoso e comercial. Rio de Janeiro, Typ. do direito, 1878.

O Três de Abril. Órgão dos interesses em geral. Rio de Janeiro, Redação, Rua Engenho de Dentro, n. 9. 1905.

Revista da Associação dos Guarda Livros. Publicação mensal consagrada ao movimento interno desta Associação e a todas as questões que possam interessar ao comércio em geral e especialmente o do Brasil. Rio de Janeiro, Typ. Cosmopolita, 1874-1875.

Revolução. Órgão Realista, Republicano, Livre Pensador e Socialista. Rio de Janeiro. Typ. Particular, 1881 e 1882.

Vinte Cinco de Março: Homenagem de Alguns Tipógrafos à Província do Ceará. Rio de Janeiro, Typ. De Augusto dos Santos, 1884.

Relatório da Sociedade União Beneficente Niteroiense no seu décimo quarto ano de existência. 
Apresentado à Assembleia Geral de 10 de janeiro de 1886. Rio de Janeiro, Typ. Carioca, Rua Theophilo Ottoni, 145. 1886.

Relatório da Sociedade de Socorros Mútuos União Familiar e Perfeita Amizade. Apresentado a Assembleia Geral de 29 de janeiro de 1886, pelo presidente João Silveira Avila de Mello. Rio de Janeiro, Typ. Carioca, Rua Theophilo Ottoni, 145. 1886.

Relatório da Imperial Sociedade Auxiliadora das Artes Mecânicas e Liberais e Beneficente. Da qual são augustos protetores SS. MM. II. apresentado pelo conselho à assembleia geral ordinária. Rio de Janeiro, Typ. Universal de E. \& H. Laemmert, Rua dos Inválidos, 71. 1876.

Relatórios dos Presidentes de Província do Rio de Janeiro (1835 - 1889). http://brazil.crl.edu 